UNIVERSIDADE DE SÃO PAULO

ESCOLA DE ENGENHARIA DE SÃO CARLOS

INDARA SOTO IZQUIERDO

\title{
UTILIZAÇÃO DE PÓS RESIDUAIS E FIBRA DE SISAL EM BLOCOS DE CONCRETO
}

São Carlos, São Paulo

2015 



\section{INDARA SOTO IZQUIERDO}

Utilização de pós residuais e fibra de sisal em blocos de concreto

Tese apresentada ao Departamento de Engenharia de Estruturas da EESC-USP, como parte dos requisitos para a obtenção do título de Doutor em Engenharia Civil.

Área de concentração: Estruturas

Orientador: Prof. Titular Dr. Marcio Antonio Ramalho

\section{VERSÃO CORRIGIDA}

A versão original encontra-se na Escola de Engenharia de São Carlos

São Carlos 
AUTORIZO A REPRODUCÃO TOTAL OU PARCIAL RESTE TRABALHO, POR QUALQUER MEIO CONVENCIONAL OU ELETRONICO, PARA FINS DE ESTUDO E PESQUISA, DESDE QUE CITADA A FONTE.

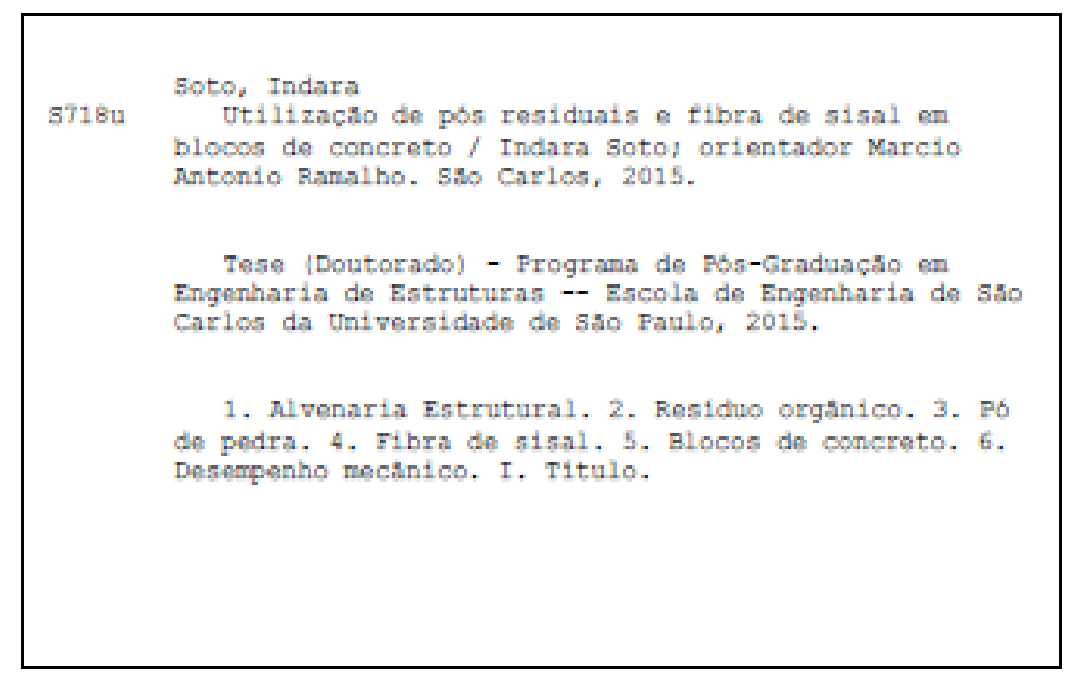




\section{FOLHA DE JULGAMENTO}

Candidata: Engenheira INDARA SOTO IZQUIERDO.

Título da Tese: "Utilização de pós residuais e fibra de sisal em blocos de alvenaria estrutural".

Data da defesa: $27 / 05 / 2015$

Comissão Julgadora:

Prof. Titular Marcio Antonio Ramalho (Orientador)

(Escola de Engenharia de São Carlos/EESC)

Prof. Associado Márcio Roberto Silva Corrêa

(Escola de Engenharia de São Carlos/EESC)

Prof. Dr. Almir Salles

(Universidade Federal de São Carlos/UFSCar)

Prof. Dr. Jefferson Sidney Camacho

(Universidade Estadual Paulista "Júlio de Mesquita Filho"/UNESP-Ilha Solteira)

Prof. Dr. Guilherme Aris Parsekian

(Universidade Federal de São Carlos/UFSCar)

Coordenador do Programa de Pós-Graduação em Engenheira Civil (Engenharia de Estruturas):

Prof. Titular Humberto Breves Coda

Presidente da Comissão de Pós-Graduação:

Prof. Associado Paulo Sergio Lima Segantine

\section{Resultado:}
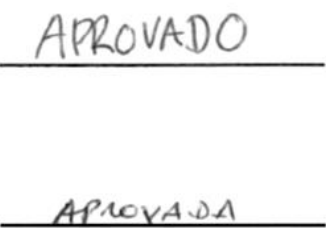

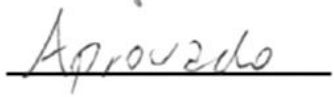



Dedico este trabajo a mis abuelos Carmen (in memoriam), Felipe (in memoriam), José Manuel (in memoriam) e Consuelo por ser ellos mi orgullo y el ejemplo de lo que un día quiero ser. 



\section{Agradecimentos}

A Deus por ser presença, fé e amor.

Aos meus pais, Felipe e Esperanza, pelo incentivo, carinho e apoio, por estarem sempre presentes, pelo desvelo e desmedida preocupação.

À minha irmã Orieta, meu resguardo, minha proteção, minha alma, minha razão de existir.

Ao meu namorado Iván pela companhia, pela preocupação, pelos conselhos e críticas construtivas, pelas palavras de incentivo e principalmente pelo amor.

Ao meu orientador Prof. Marcio Antonio Ramalho, pela orientação, disponibilidade, paciência e contribuições.

À minha prima-irmã Patry pelo carinho desmedido e entrega incondicional, pela alegria e dedicação.

À minha cunhada Lianet por compartir juntas esta difícil batalha e pelo apoio nos momentos difíciles.

Aos meus irmãos Lian e Ariel pela confiança e carinho, e à meu cunhado Luiz pela sua disposição sempre em ajudar e sua bondade ilimitada.

À minha família de Cuba pela presencia apesar da distância, em especial minha tia Fina pelo amor ilimitado e constante preocupação.

Aos professores Almir Sales e Márcio Côrrea, obrigada pelas sugestões durante o exame de qualificação.

Aos meus amigos que conquistei neste período, Felipe, Jose, Ellen, Wagner, Érica, Jesús Daniel, Jesús García, Carolina pelo companheirismo e em especial a Marcela pela amabilidade, simpatia e generosidade.

Agradeço a todos os funcionários do laboratório pela ajuda durante os quase três anos de atividades no laboratório: Luís Vareda, Mário, Mauri, Fabiano, Romeu e em especial o Douglas.

A todos os funcionários da secretaria do Departamento de Estruturas pelas valiosas colaborações.

Ao $\mathrm{CNPq}$ pelo financiamento da bolsa de estudo, à FAPESP pelo auxilio à pesquisa e ao Departamento de Estruturas da USP de São Carlos pela oportunidade que me foi dada de realizar o doutorado. 



\section{RESUMO}

SOTO, I. I. (2015). Utilização de pós residuais e fibra de sisal em blocos de concreto. Tese (Doutorado)- Escola de Engenharia de São Carlos, Universidade de São Paulo, São Carlos, 2015.

A pesquisa tem como enfoque fundamental a aplicação de novos materiais alternativos para uma construção sustentável. Pós residuais, provenientes do resíduo orgânico e do setor mineral, e fibras de sisal constituem bons exemplos de materiais não convencionais. Dessa forma, o objetivo principal foi avaliar a incorporação dos pós residuais e da fibra de sisal no concreto para a fabricação de blocos de concreto e elementos de alvenaria. Foram estudados três relações cimento: agregado, de 1:15, 1:10 e 1:6 (traços pobre, médio e rico), com a finalidade de produzir blocos estruturais com classe de resistência, de 4, 8 e $12 \mathrm{MPa}$, respectivamente. Para cada traço foi realizada a substituição da areia natural por pó de pedra com teores de $20 \%, 40 \%, 60 \%$ e $80 \%$, em massa, e do cimento por pó de resíduo orgânico com teores de 5\%, 10\%, 15\% e 20\%, em massa. Foi feito o estudo da durabilidade da fibra de sisal em meio alcalino, com comprimento de $20 \mathrm{~mm}$ e fração volumétrica de $1 \%$ com relação ao concreto. Foram estudadas as propriedades físicas e mecânicas do concreto no estado fresco e endurecido.

Os resultados mostraram que os pós residuais podem ser utilizados como fíler no concreto substituindo parte da matéria prima, uma vez que causaram o correto empacotamento nos agregados e na pasta de cimento. O estudo estatístico utilizando a técnica do Bootstrap mostrou que para o pó de pedra, a porcentagem ideal para a substituição da areia pelo pó no concreto foi de $60 \%$ para os traços 1:15 e 1:10 e de 40\% para o traço 1:6. Já no pó de resíduo orgânico, concretos com baixo consumo de cimento, o resíduo não teve um correto enchimento na matriz cimentícia; com médio consumo, o concreto com 5\% de pó apresentou propriedades mecânicas e físicas superiores ao concreto de referência; e em misturas ricas em cimento, porcentagens até $10 \%$ provocaram um correto desempenho mecânico quando comparados ao concreto de referência. $\mathrm{O}$ sisal apresentou alta durabilidade em matrizes cimentícias modificadas com materiais pozolânicos devido à diminuição do hidróxido de cálcio $(\mathrm{CH})$. Foi possível concluir que os blocos de concreto modificados com os materiais alternativos apresentaram qualidade compatível com as exigências da construção civil nacional e podem ser utilizados também como unidades de vedação.

Palavras-chave: Alvenaria estrutural. resíduo orgânico. pó de pedra. fibra de sisal. blocos de concreto. desempenho mecânico. 



\begin{abstract}
SOTO, I. I. (2015). Use of residual powders and sisal fiber in concrete blocks. Doctoral Thesis School of Engineering of São Carlos, University of São Paulo, São Carlos, 2015.

This research deals with the use of new alternative materials for sustainable construction. The use of residual powder materials, from organic residue and from mineral sector, and sisal fibers are good examples of unconventional materials that can be used. The main objective is to evaluate the use of residual powders and sisal fibers in the production of structural masonry blocks. Three types of mixtures for cement consumption were studied: aggregate/cement $(\mathrm{A} / \mathrm{C})$ ratios of 15,10 , and 6 , in order to produce blocks structural strength classes of 4,8 and $12 \mathrm{MPa}$, respectively. For each trace the cement were replaced by powder organic waste at levels of $5 \%, 10 \%, 15 \%$ and $20 \%$, and natural sand replaced by stone powder at levels of $20 \%, 40 \%, 60 \%$ and $80 \%$. A study was carried out in order to evaluate the durability of sisal fiber in the alkaline medium, with length of $20 \mathrm{~mm}$ and $1 \%$ volume fraction on the concrete. The physical and mechanical properties of fresh and hardened concrete were studied.

The results showed that residual powder can be used as filler in concrete by replacing part of the raw material, since they caused the correct packaging in the aggregates and in the cement paste. The statistical analysis using the Bootstrap technique showed that for the stone powder the optimal percentage for replacing the sand was $60 \%$ for $15: 1$ and 10:1 traces and $40 \%$ for 6:1 trace. As for the organic residual powder, the results showed that the reference concrete had higher compressive strength than the concrete with low cement content $(\mathrm{A} / \mathrm{C}$ ratio of 15:1). However, samples made with 5\% powder and an A/C ratio of 10:1 showed greater physical and mechanical properties strength than the reference concrete. Mixtures rich in cement $(\mathrm{A} / \mathrm{C}$ ratio of $6: 1)$ and the powder replacements of up to $10 \%$ resulted in the best mechanical behavior. The sisal showed high durability in modified cementitious matrices with pozzolanic materials due to decreased calcium hydroxide $(\mathrm{CH})$. It was concluded that the blocks modified with alternative materials showed quality compatible with the requirements of national construction.
\end{abstract}

Keywords: Recycl. organic waste. powder natural stone. sisal fiber. concrete blocks. mechanical performance. 



\section{SUMÁRIO}

1. INTRODUÇÃO 33

1.1. Objetivo principal 33

1.2. Objetivos específicos

1.3. Resultados previstos $\quad 34$

1.4. Justificativas 35

1.4.1. Impactos científicos e tecnológicos $\quad 35$

1.4.1.1. Pó de resíduo orgânico 35

1.4.1.2. Pó de pedra 35

1.4.1.3. Fibra de sisal 36

1.4.2. Impactos ambientais $\quad 36$

1.4.2.1. Resíduo orgânico 36

1.4.2.2. Pó de pedra 37

1.4.3. Impactos econômicos e sociais $\quad 37$

$\begin{array}{lll}\text { 1.5. } & \text { Metodologia } & 38\end{array}$

1.6. Estrutura do texto $\quad 40$

2. USO DE RESÍDUOS NA CONSTRUÇÃO CIVIL

2.1. Utilização de resíduos para fabricação de blocos de concreto: uma opção para a sustentabilidade $\quad 43$

2.2. Definição e características do resíduo orgânico, pó de pedra e fibra de sisal. 47

2.2.1. Resíduo orgânico $\quad 47$

2.2.2. Pó de pedra 48

2.2.3. Fibra de sisal 49

2.3. Utilização de pó de resíduo orgânico, pó de pedra e fibra de sisal na construção civil 52

2.3.1. Pó residual orgânico 52

2.3.2. Pó de pedra $\quad 56$

2.3.3. Fibra de sisal $\quad 58$

2.4. Concreto reforçado com fibras 62

3. ALVENARIA DE BLOCOS DE CONCRETO 65

3.1. Bloco de concreto $\quad 65$ 
3.1.1. Materiais constituintes

3.1.2. Processo de fabricação dos blocos de concreto 67

$\begin{array}{ll}\text { 3.2. } & \text { Metodologias de dosagem } \\ \end{array}$

3.3. Argamassa de assentamento $\quad \mathbf{7 2}$

$\begin{array}{lll}\text { 3.3.1. } & \text { Propriedades } & 72\end{array}$

$\begin{array}{lll}\text { 3.3.2. } & \text { Tipos de argamassas } & 73\end{array}$

$\begin{array}{lll}\text { 3.3.3. Dosagem } & 73\end{array}$

3.3.4. Resistência à compressão $\quad 76$

3.3.5. Aderência $\quad 76$

3.4. Avaliação do comportamento mecânico na alvenaria 77

$\begin{array}{lll}\text { 3.5. } & \text { Mecanismo de ruptura dos elementos } & 79\end{array}$

3.6. Avaliação do módulo de elasticidade da alvenaria à compressão simples (Ealv) 84

3.7. Comportamento do diagrama tensão vs deformação para as alvenarias à compressão

4. DESENVOLVIMENTO EXPERIMENTAL 91

4.1. Processo para a obtenção dos pós residuais e da fibra de sisal 91

4.1.1. Sistema de tratamento e beneficiamento do resíduo orgânico 91

4.1.2. Obtenção do pó de pedra por meio do processo de produção da brita 93

4.1.3. Colheita e pós-colheita da fibra de sisal 95

4.2. Caracterização química e física dos pós residuais e da fibra de sisal 96

4.2.1. Pó residual de resíduo orgânico 96

4.2.1.1. Microscopia eletrônica de varredura (MEV) 97

4.2.1.2. Espectroscopia de energia dispersiva por raio-X (EDS) 97

4.2.1.3. Análise dos metais pesados 98

4.2.1.4. Massas específica e unitária e análise granulométrica 99

4.2.2. Pó de pedra 100

$\begin{array}{lll}\text { 4.2.3. } & \text { Fibra de sisal } & 100\end{array}$

4.2.3.1. Massa específica real e aparente 101

4.2.3.2. Teor de umidade inicial 103

4.2.3.3. Absorção de água 103

4.3. Caracterização dos materiais empregados no concreto para blocos 104

4.3.1. Cimento Portland 105

4.3.2. Agregados miúdo e graúdo $\quad 105$ 
4.5. Produção de corpos de prova cilíndricos $(5 \mathrm{~cm} \times 10 \mathrm{~cm})$

4.6. Fabricação dos blocos de concreto

4.7. Avaliação e caracterização dos blocos

4.7.1. Análise dimensional

4.7.2. Absorção de água e área líquida

4.7.3. Teor de umidade

4.7.4. Massas específicas

4.8. Argamassa de assentamento $\quad \mathbf{1 2 2}$

4.8.1. Ensaio de resistência à compressão da argamassa de assentamento 124

4.9. Ensaio de resistência à compressão dos blocos, prismas e pequenas paredes 126

4.9.1. Ensaio de resistência à compressão dos blocos 126

4.9.2. Ensaio de resistência à compressão dos prismas 127

4.9.3. Ensaio de resistência à compressão das pequenas paredes $\quad 128$

4.10. Capeamento dos blocos 130

4.11. Módulo de deformação de prismas e pequenas paredes 131

4.11.1. Módulo de deformação dos prismas 131

4.11.2. Módulo de deformação das pequenas paredes 132

4.12. Aumento e avaliação da durabilidade da fibra de sisal no concreto 133

5. RESULTADOS E DISCUSSÕES: MATERIAIS E CORPOS DE PROVA 137

5.1. Caracterização do pó de resíduo orgânico 137

5.1.1. Microscopia eletrônica de varredura (MEV) 137

5.1.2. Análise química 139

5.1.3. Análise dos metais pesados $\quad 140$

5.1.4. Caracterização física $\quad 140$

5.2. Caracterização da fibra de sisal 141

5.3. Caracterização do pó de pedra, areia, pedrisco e cimento. 142

5.3.1. Cimento Portland 143

5.3.2. Agregados miúdos $\quad 143$

$\begin{array}{lll}\text { 5.3.3. Agregado graúdo } & 145\end{array}$

5.4. Avaliação das propriedades dos corpos de prova de concreto para cada traço estudado $\quad 146$

5.4.1. Corpos de prova com pó de pedra substituindo a areia 146

$\begin{array}{ll}\text { 5.4.1.1. Propriedades físicas do concreto fresco } & 146\end{array}$ 
5.4.1.2. Propriedades físicas do concreto endurecido 148

5.4.1.3. Resistência à compressão dos corpos de prova com pó de pedra 149

5.4.1.4. Escolha da porcentagem ideal do pó de pedra no concreto 155

5.4.2. Corpos de prova com pó residual orgânico substituindo o cimento 156

5.4.2.1. Propriedades físicas do concreto fresco 156

5.4.2.2. Propriedades físicas do concreto endurecido 158

5.4.2.3. Resistência à compressão dos corpos de prova com pó residual de resíduo orgânico 159

5.4.2.4. Escolha da porcentagem ideal do pó residual orgânico no concreto

\section{RESULTADOS E DISCUSSÕES: BLOCOS E ELEMENTOS DE ALVENARIA ESTRUTURAL}

$\begin{array}{lll}\text { 6.1. Nomenclatura adotada para os blocos } & 167\end{array}$

6.2. Propriedades geométricas dos blocos $\quad 168$

$\begin{array}{lll}\text { 6.2.1. } & \text { Análise dimensional } & 168\end{array}$

6.2.2. Área bruta e área líquida $\quad 169$

6.3. Propriedades físicas dos blocos $\quad 169$

6.3.1. Massa específica $\quad 169$

6.3.1.1. Blocos produzidos com os pós residuais 169

6.3.1.2. Blocos com adição da fibra de sisal $\quad 170$

$\begin{array}{lll}\text { 6.3.2. Absorção de água } & 171\end{array}$

6.3.2.1. Blocos produzidos com os pós residuais 171

6.3.2.2. Blocos com adição da fibra de sisal 172

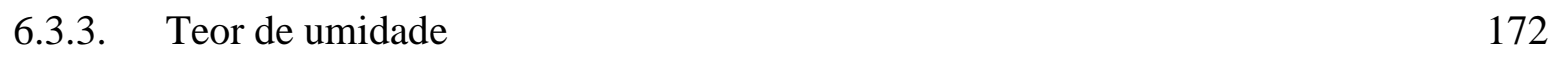

6.4. Resistência à compressão dos blocos e meio-blocos 173

6.4.1. Blocos produzidos com os pós residuais 173

6.4.2. Meio-blocos produzidos com os pós residuais $\quad 175$

$\begin{array}{lll}\text { 6.4.3. Blocos com adição de fibra de sisal } & 177\end{array}$

6.4.4. Meio-blocos com adição de fibra de sisal $\quad 180$

6.5. Modos de ruptura dos blocos $\quad 181$

6.6. Resistência à compressão da argamassa de assentamento 183

6.7. Resistência à compressão dos prismas $\quad 184$

6.7.1. Prismas produzidos com os pós residuais 185

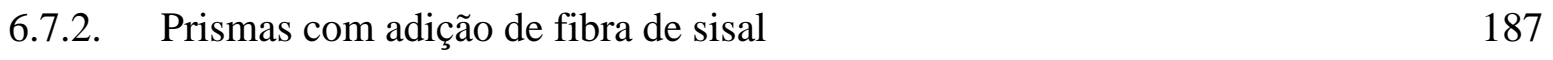

$\begin{array}{llr}\text { 6.8. } & \text { Modos de ruptura dos prismas } & 189\end{array}$

6.9. Módulo de deformação dos prismas 191

6.9.1. Prismas produzidos com os pós residuais 191 
6.10. Resistência à compressão das pequenas paredes 196

6.10.1. Pequenas paredes produzidas com os pós residuais 196

6.10.2. Pequenas paredes com adição de fibra de sisal 198

6.11. Modos de ruptura das pequenas paredes 200

6.12. Módulo de deformação das pequenas paredes 203

6.12.1. Pequenas paredes produzidas com os pós residuais 203

6.12.2. Pequenas paredes produzidas com adição de fibra de sisal 205

6.13. Avaliação da durabilidade da fibra de sisal no concreto 207

6.13.1. Resistência à tração indireta dos blocos 207

6.13.2. Análise da microestrutura do compósito 210

7. CONCLUSÕES E RECOMENDAÇÕES PARA TRABALHOS FUTUROS 215

$\begin{array}{lll}\text { 7.1. } & \text { Recomendações para trabalhos futuros } & 218\end{array}$

REFERÊNCIAS

APÊNDICE A - TÉCNICA ESTATÍSTICA DO BOOTSTRAP 235

$\begin{array}{ll}\text { A1 Introdução } & 235\end{array}$

A2 Procedimento de cálculo do Bootstrap 235

A3 Número de reamostras adequado 236

A4 Procedimento da técnica do Bootstrap para obter intervalos de confiança da $\begin{array}{ll}\text { resistência característica } & 238\end{array}$

APÊNDICE B - ANÁLISE DA DIFERENÇA ENTRE DUAS MÉDIAS COM O MÉTODO BOOTSTRAP $\quad 241$

B1 Introdução 241

B2 Procedimento de cálculo 241

APÊNDICE C - RESULTADOS DAS PROPRIEDADES GEOMÉTRICAS DOS BLOCOS 



\section{LISTA DE FIGURAS}

Figura 2.1 - Pó de pedra no pátio da pedreira ao ar livre 48

Figura 2.2 - Planta do sisal.

Figura 2.3 - Morfologia da fibra de sisal: (a) fibra composta por células individuais ligadas pela lamela intercelular e (b) detalhe da célula individual. ...................................................50

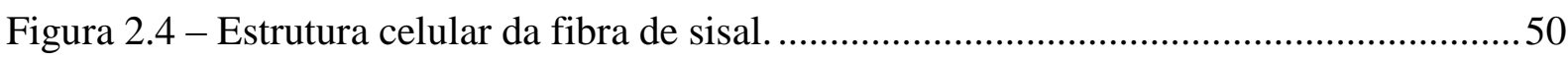

Figura 3.1 - Valores limites para que a mistura seja de granulometria densa. ....................... 71

Figura 3.2 - Elementos de alvenaria de bloco de concreto: (a) prisma e (b) pequena parede .78

Figura 3.3 - Estado de tensões atuantes nos blocos e nas juntas de argamassa. 79

Figura 3.4 - Modo de ruptura e mecanismo gerador de tensões horizontais em prismas de blocos de concreto, com argamassamento nas faces longitudinais 80

Figura 3.5 - Modo de ruptura de prismas com argamassamento total

Figura 3.6 - Modo de ruptura dos prismas concreto com diferentes traços de argamassa: (a) prismas com argamassa 1: 1: 6 e (b) prisma com argamassa 1: 0.5: 4.5).

Figura 3.7 - Diagrama tensão-deformação axial e lateral dos prismas com o modo de ruptura do conjunto

Figura 3.8 - Ensaio de compressão em prismas com diferentes materiais: (a) em prismas de tijolos cerâmicos e (b) ensaios de compressão em prismas de blocos de concreto .

Figura 3.9 - Ruptura das paredes por tração: (a) junta de argamassa entre os blocos, (b) argamassa confinada na região central da junta e (c) ruptura por tração dos blocos.

Figura 3.10 - Características dos módulos de elasticidade obtidos a partir do diagrama tensãodeformação

Figura 3.11 - Diagrama tensão-deformação de alvenarias à compressão obtidos usando unidades sólidas e vazadas (linha sólida e tracejada)

Figura 3.12 - Diagrama tensão-deformação de prismas de blocos de concreto: (a) Bloco M1 e (b) Bloco M2.

Figura 3.13 - Diagrama tensão vs deformação de prismas com assentamento total: (a) argamassa A1 (1:1:6) e (b) argamassa A2 (1:0,5:4,5)....

Figura 3.14 - Diagrama tensão vs deformação de prismas prisma não grauteados com assentamento lateral: (a) argamassa A1 (1:1:6) e (b) argamassa A2 (1:0,5:4,5)....

Figura 3.15 - Curva tensão vs deformação dos prismas de concreto: (a) prisma oco e (b) prisma grauteado. 90

Figura 4.1 - Etapa inicial: (a) resíduo urbano colocado na esteira de seleção e (b) seleção manual deixando os materiais orgânicos 
Figura 4.2 - Etapa intermediária: (a) trituração do resíduo orgânico e (b) transporte até a câmara de reação química

Figura 4.3 - Etapa final: (a) massa retirada do reator e (b) produto transformado em pó ....... 93

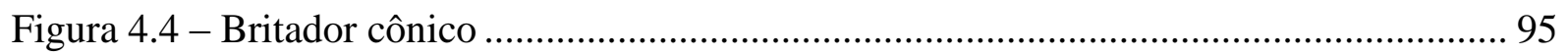

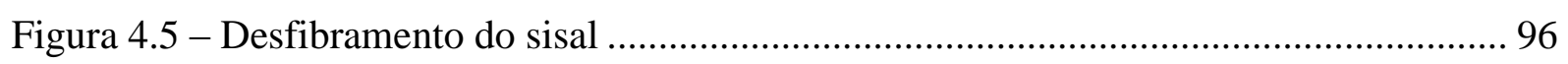

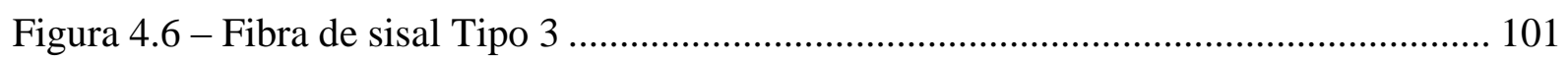

Figura 4.7 - Ensaio da fibra no frasco de $1.000 \mathrm{ml}$........................................................ 102

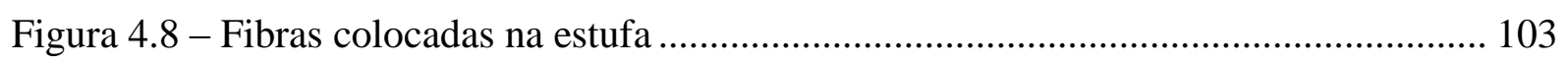

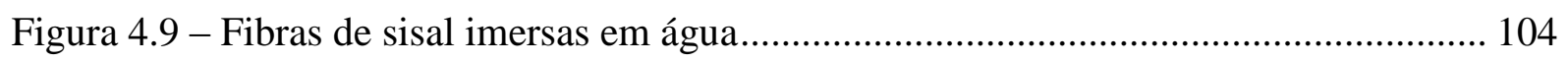

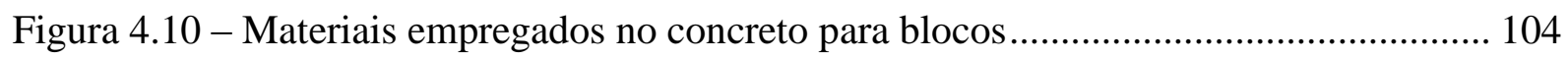

Figura 4.11 - Preenchimento do recipiente com o pedrisco ............................................. 106

Figura 4.12 - Misturas do pedrisco e da areia em diversas proporções................................. 107

Figura 4.13 - Curva do menor volume de vazios das composições pedrisco e areia ............. 108

Figura 4.14 - Moldagem de corpos de prova cilíndricos $(5 \mathrm{~cm}$ x $10 \mathrm{~cm})$........................... 110

Figura 4.15 - Mistura do concreto: (a) mistura dos materiais e (b) homogeneização final do

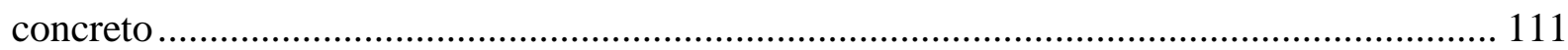

Figura 4.16 - Compactação de 20 golpes em quatro camadas ............................................. 112

Figura 4.17 - Esquema e foto de ensaio para avaliação da coesão das misturas ................... 113

Figura 4.18 - Execução dos ensaios referentes às propriedades físicas dos corpos de prova: (a) secagem na estufa, (b) determinação da massa imersa na balança hidrostática e (c) ensaio de

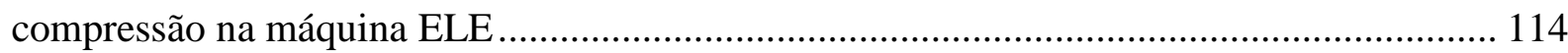

Figura 4.19 - Vibroprensa Makipen utilizada para a fabricação dos blocos no laboratório.. 115

Figura 4.20 - Sequência na execução dos blocos estruturais: (a) concreto despejado no carrinho de mão, (b) retirada do excesso de concreto com o uso de um rastelo, (c) hastes metálicas comprimindo e compactando a massa no interior da fôrma, (d) descida do braço da máquina para a elevação da caixa da matriz e retirada dos blocos, (e) cura dos blocos na câmera úmida e (f) blocos estocados no pátio do laboratório até a data dos ensaios

Figura 4.21 - Execução da análise dimensional nos blocos: (a) medição do comprimento, (b) medição da menor dimensão dos furos e (c) medição da espessura das paredes.................... 118

Figura 4.22 - Pesagem dos blocos na balança ................................................................. 119

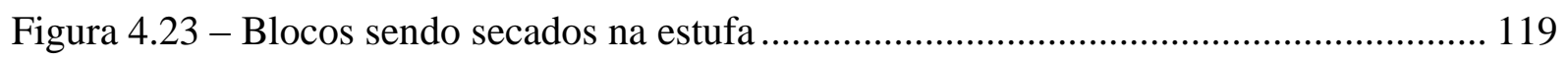

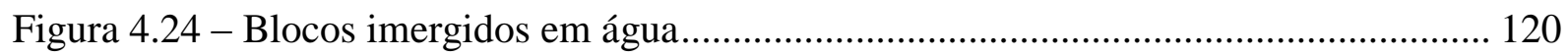

Figura 4.25 - Massa dos blocos determinada por meio da balança hidrostática .................. 121

Figura 4.26 - Ensaio de consistência da argamassa.......................................................... 123 
Figura 4.27 - Moldagem da argamassa em corpos de prova cúbicos

Figura 4.28 - Ensaio de resistência a compressão da argamassa

Figura 4.29 - Ensaio de resistência a compressão do bloco

Figura 4.30 - Disposição dos cordões de argamassa nos prismas

Figura 4.31 - Ensaio de resistência à compressão dos prismas

Figura 4.32 - Assentamento das fiadas superiores verificando-se o nível, o prumo e a planeza

Figura 4.33 - Ensaio de resistência à compressão das pequenas paredes

Figura 4.34 - Capeamento dos blocos: (a) distribuição da pasta com espessura de $3 \pm 1 \mathrm{~mm}$, (b) nivelamento do bloco com o auxílio do nível de bolha, (c) retirada do excesso de massa das laterais do bloco e (d) desforma dos blocos após 12 horas

Figura 4.35 - Vista frontal e em planta da localização dos clip-gauges nos prismas

Figura 4.36 - Vista frontal e em planta da localização dos transdutores de deslocamento nas pequenas paredes

Figura 4.37 - Ensaio de resistência à tração indireta dos blocos

Figura 5.1 - Microimagens das partículas do pó residual orgânico

Figura 5.2 - Espectros obtidos por EDS de três amostras de pó de resíduo orgânico

Figura 5.3 - Absorção de água das fibras de sisal ao longo do tempo

Figura 5.4 - Comparação entre a areia utilizada e a especificada pela NBR 7211: 2009 ...... 144

Figura 5.5 - Comparação entre o pó de pedra e os limites especificados NBR 7211: 2009.. 144

Figura 5.6 - Diagrama de caixa para os dados de resistência à compressão do concreto com pó de pedra para o traço $1: 15$.

Figura 5.7 -Diagrama de caixa para os dados da resistência à compressão do concreto com pó de pedra para o traço $1: 10$.

Figura 5.8 - Diagrama de caixa para os dados da resistência à compressão do concreto com pó de pedra para o traço 1:6. 154

Figura 5.9 - Diagrama de caixa para os dados da resistência à compressão do concreto com pó residual orgânico para o traço 1:15

Figura 5.10 - Diagrama de caixa para os dados da resistência à compressão do concreto com pó residual orgânico para o traço 1:10

Figura 5.11 - Diagrama de caixa para os dados da resistência à compressão do concreto com pó residual orgânico do traço 1:6

Figura 6.1 - Diagrama de caixa para os dados da resistência à compressão dos blocos com os pós residuais 
Figura 6.2 - Diagrama de caixa para os dados da resistência à compressão dos meio-blocos com os pós residuais

Figura 6.3 - Diagrama de caixa para os dados da resistência à compressão dos blocos com fibra de sisal

Figura 6.4 - Diagrama de caixa para os dados da resistência à compressão dos meio-blocos com fibra de sisal

Figura 6.5 - Modo de ruptura dos blocos de concreto ........................................................ 182

Figura 6.6 - Ruptura frágil dos blocos sem adição de fibra ............................................. 182

Figura 6.7 - Ruptura dos blocos com adição de fibra......................................................... 183

Figura 6.8 - Diagrama de caixa para os dados da resistência à compressão dos prismas com os

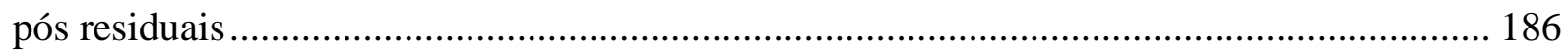

Figura 6.9 - Diagrama de caixa para os dados da resistência à compressão dos prismas com

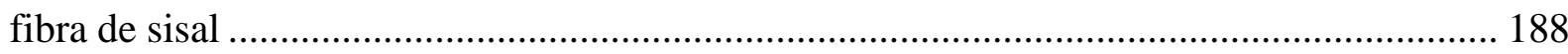

Figura 6.10 - Ruptura típica dos prismas sob compressão: (a) PR1:15-Ref, (b) PR1:155\%P.L, (c) PR1:10-5\%P.L, (d) PR1:10-Ref, (e) PR1:6-Ref e (f) PR1:6-10\%P.L ............... 190

Figura 6.11 - Ruptura dos prismas com fibras sob compressão: (a) PR1:10-F1 e (b) PR1:10-

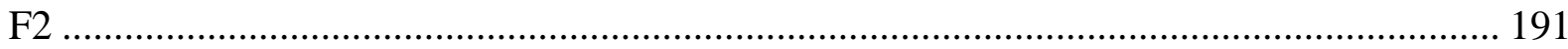

Figura 6.12 - Curvas tensão vs deformação dos prismas com os pós residuais .................... 193

Figura 6.13 - Curvas tensão vs deformação dos prismas com adição de fibra de sisal......... 195

Figura 6.14 - Diagrama de caixa para os dados da resistência à compressão das paredes com os pós residuais .

Figura 6.15 - Diagrama de caixa para os dados da resistência à compressão das paredes com fibra de sisal

Figura 6.16 - Propagação de fissuras verticais de tração ................................................... 201

Figura 6.17 - Fissuras verticais ao longo dos septos laterais............................................. 202

Figura 6.18 - Ruptura das paredes sob compressão: (a) ruptura frágil das paredes sem adição de fibras, (b) ruptura dúctil das paredes com adição de fibras............................................. 202

Figura 6.19 - Curvas tensão vs deformação das paredes com os pós residuais .................... 204

Figura 6.20 - Curvas tensão vs deformação das paredes com adição de fibra de sisal ......... 206

Figura 6.21 - Curvas tração indireta vs abertura da fissura................................................ 208

Figura 6.22 - Ruptura dos blocos no ensaio de resistência à tração indireta: (a) ruptura frágil dos blocos sem adição de fibras e (b) ruptura dúctil dos blocos com adição de fibras.......... 209

Figura 6.23 - Microimagens da seção longitudinal da fibra isolada: (a) em estado natural, (b) extraída da matriz com cimento Portland ARI e (c) extraída da matriz modificada ............. 210 
Figura 6.24 - Espectros obtidos por EDS da fibra de sisal (a) em estado natural, (b) extraída da matriz com cimento Portland ARI e (c) extraída da matriz modificada........................... 211

Figura 6.25 - Microimagens da matriz reforçada com a fibra de sisal: (a) matriz comum e (b) matriz modificada

Figura 6.26 - Espectros obtidos por EDS na zona de transição fibra/matriz: (a) mistura comum e (b) mistura modificada 



\section{LISTA DE TABELAS}

Tabela 2.1- Propriedades físicas e mecânicas da fibra de sisal..............................................52

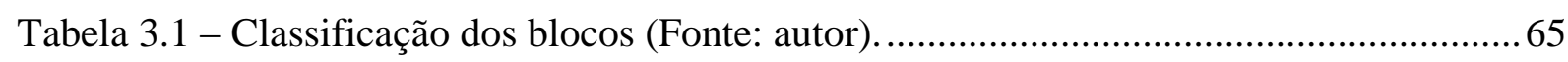

Tabela 3.2 - Exigências mínimas das argamassas NBR 13281: 2005 .................................... 74

Tabela 3.3 - Especificações dos traços das argamassas da ASTM C270: 1987. ..................... 75

Tabela 3.4 - Especificações das propriedades das argamassas de cimento e cal da ASTM

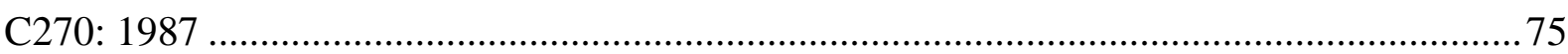

Tabela 3.5 - Traços das argamassas de assentamento segundo a BS 5628 - 1: 1992 ............. 76

Tabela 4.1 - Ensaios e metodologia empregados para caracterização do pó de resíduo orgânico

Tabela 4.2 - Influência dos metais pesados na reatividade hidráulica e na qualidade do cimento e concreto

Tabela 4.3 - Resultados de massa unitária e volume de vazios para cada uma das composições de pedrisco e areia 108

Tabela 4.4 - Composições de materiais para $1 \mathrm{~m} 3$ 109

Tabela 4.5 - Dados da moldagem dos corpos de prova com substituição do pó de pedra.....110

Tabela 4.6 - Dados da moldagem dos corpos de prova com substituição do pó de resíduo.. 111

Tabela 4.7 - Ensaios referentes ao concreto fresco e endurecido dos corpos de prova ..........112

Tabela 4.8 - Resistência à compressão e traço em volume da argamassa ............................. 122

Tabela 4.9 - Características das argamassas utilizadas no ensaio piloto ................................ 125

Tabela 5.1 - Dimensão das partículas do pó residual orgânico............................................... 138

Tabela 5.2 - Composição química das três amostras do pó de resíduo orgânico.................... 139

Tabela 5.3 - Metais analisados nas amostras do pó residual orgânico....................................140

Tabela 5.4 - Massas específicas real e aparente e teor de umidade das fibras de sisal.......... 141

Tabela 5.5 - Absorção de água das fibras no tempo .............................................................. 142

Tabela 5.6 - Características físicas e mecânicas do cimento CP V-ARI RS e CP III-40 RS 143

Tabela 5.7 - Análise granulométrica da areia e do pó de pedra utilizados nos blocos ........... 143

Tabela 5.8 - Características físicas da areia e do pó de pedra................................................ 145

Tabela 5.9 - Caracterização física do agregado graúdo ...................................................... 145

Tabela 5.10 - Propriedades físicas do concreto fresco com pó de pedra para o traço 1:15 ... 146

Tabela 5.11 - Propriedades físicas do concreto fresco com pó de pedra para o traço 1:10 ... 147

Tabela 5.12 - Propriedades físicas do concreto fresco com pó de pedra para o traço 1:6 ..... 147 
Tabela 5.13 - Propriedades físicas do concreto endurecido com pó de pedra para o traço 1:15

Tabela 5.14 -Propriedades físicas do concreto endurecido com pó de pedra para o traço 1:10

Tabela 5.15 - Propriedades físicas do concreto endurecido com pó de pedra para o traço 1:6

Tabela 5.16 -Resistência à compressão do concreto com pó de pedra para o traço $1: 15 \ldots \ldots .150$ Tabela 5.17 -Probabilidade de que as hipóteses nulas sejam aceitas para o concreto com pó de pedra para o traço 1:15.

Tabela 5.18 - Resistência à compressão do concreto com pó de pedra para o traço 1:10..... 152

Tabela 5.19 - Probabilidade de que as hipóteses nulas sejam aceitas para o concreto com pó

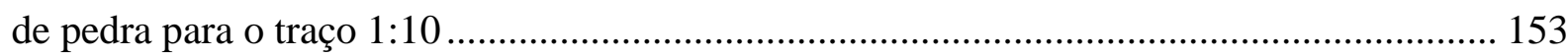

Tabela 5.20 -Resistência à compressão do concreto com pó de pedra para o traço 1:6........ 154

Tabela 5.21 - Probabilidade de que as hipóteses nulas sejam aceitas para o concreto com pó

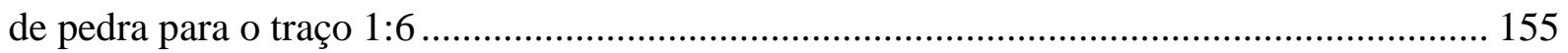

Tabela 5.22 - Propriedades físicas do concreto fresco com pó residual de resíduo orgânico para o traço $1: 15$

Tabela 5.23 - Propriedades físicas do concreto fresco com pó residual de resíduo orgânico para o traço $1: 10$

Tabela 5.24 - Propriedades físicas do concreto fresco com pó residual orgânico para o traço $1: 6$

Tabela 5.25 -Propriedades físicas do concreto endurecido com pó residual de resíduo orgânico para o traço 1:15.

Tabela 5.26 - Propriedades físicas do concreto endurecido com pó residual orgânico para o traço $1: 10$. 158

Tabela 5.27 - Propriedades físicas do concreto endurecido com pó residual de resíduo orgânico para o traço 1:6

Tabela 5.28 - Resistência à compressão do concreto com pó de resíduo orgânico para o traço 1:15.

Tabela 5.29 - Probabilidade de que as hipóteses nulas sejam aceitas para o concreto com pó residual orgânico para o traço 1:15

Tabela 5.30 - Resistência à compressão do concreto com pó de resíduo orgânico para o traço 1:10. 
Tabela 5.31 - Probabilidade de que as hipóteses nulas sejam aceitas para o concreto com pó de resíduo orgânico para o traço 1:10

Tabela 5.32 - Resistência à compressão do concreto com pó de resíduo orgânico para o traço $1: 6$

Tabela 5.33 - Probabilidade de que as hipóteses nulas sejam aceitas para o concreto com pó de resíduo orgânico para o traço 1:6...... 165

Tabela 6.1 - Terminologia e características de cada série de blocos 168

Tabela 6.2 - Valores de área bruta e líquida dos blocos

Tabela 6.3 - Massa específica dos blocos produzidos com os pós residuais 170

Tabela 6.4 - Massa específica dos blocos com adição da fibra de sisal 170

Tabela 6.5 - Absorção de água dos blocos produzidos com os pós residuais 171

Tabela 6.6 - Absorção de água dos blocos com adição da fibra de sisal 172

Tabela 6.7 - Teor de umidade dos blocos 172

Tabela 6.8 - Resistência à compressão média e característica dos blocos com os pós residuais

Tabela 6.9 - Probabilidade de que as hipóteses nulas sejam aceitas para os blocos com os pós residuais

Tabela 6.10 - Resistência à compressão média e característica dos meio-blocos com os pós residuais

Tabela 6.11 - Probabilidade de que as hipóteses nulas sejam aceitas para os meio-blocos com os pós residuais

Tabela 6.12 - Resistência à compressão média e característica dos blocos com adição da fibra de sisal

Tabela 6.13 - Probabilidade de que as hipóteses nulas sejam aceitas para os blocos com fibra de sisal

Tabela 6.14 - Resistência à compressão média e característica dos meio-blocos com adição de fibra de sisal

Tabela 6.15 - Probabilidade de que as hipóteses nulas sejam aceitas para os meio-blocos com fibra de sisal

Tabela 6.16 - Resistência à compressão das argamassas

Tabela 6.17 - Resistência à compressão dos prismas com os pós residuais

Tabela 6.18 - Probabilidade de que as hipóteses nulas sejam aceitas para os prisma com os pós residuais

Tabela 6.19 - Resistência à compressão dos prismas com adição de fibra de sisal 
Tabela 6.20 - Probabilidade de que as hipóteses nulas sejam aceitas para os prismas com fibra de sisal

Tabela 6.21 - Módulo de deformação dos prismas com os pós residuais

Tabela 6.22 - Módulo de deformação dos prismas com adição de fibra de sisal

Tabela 6.23 - Resistência à compressão das pequenas paredes com os pós residuais

Tabela 6.24 - Probabilidade de que as hipóteses nulas sejam aceitas para as paredes com os pós residuais

Tabela 6.25 - Resistência à compressão das pequenas paredes com adição de fibra de sisal 198 Tabela 6.26 - Probabilidade de que as hipóteses nulas sejam aceitas para as paredes com fibra de sisal 200

Tabela 6.27 - Módulo de deformação das paredes com os pós residuais 203

Tabela 6.28 - Módulo de deformação das paredes com adição de fibra de sisal 205

Tabela 6.29 - Resistência à tração indireta dos blocos reforçados com a fibra de sisal. 207

Tabela 6.30 - Energia de fratura dos blocos reforçados com a fibra de sisal 209 


\title{
LISTA DE SÍMBOLOS
}

\author{
$\mathrm{A}_{\text {bruta }} \quad$ Área bruta \\ $\mathrm{A}_{\text {liq }} \quad$ Área líquida \\ CV Coeficiente de variação \\ $\mathrm{E}_{\mathrm{p}} \quad$ Módulo de deformação dos prismas \\ $\mathrm{E}_{\mathrm{pp}} \quad$ Módulo de deformação das pequenas paredes \\ $\mathrm{f}_{\mathrm{a}}$ Resistência média à compressão da argamassa \\ $\mathrm{f}_{\mathrm{bm}} \quad$ Resistência média à compressão dos blocos referida na área bruta \\ $\mathrm{f}_{\mathrm{bk}} \quad$ Resistência característica à compressão dos blocos \\ $\mathrm{f}_{\mathrm{cb}} \quad$ Resistência média à compressão dos blocos referida na área líquida \\ $\mathrm{f}_{\mathrm{p}} \quad$ Resistência média à compressão dos prismas \\ $\mathrm{f}_{\mathrm{pp}} \quad$ Resistência média à compressão das pequenas paredes \\ $\mathrm{f}_{\mathrm{tb} \text {, ind }}$ Resistência média à tração indireta do bloco referida na área líquida \\ GPa Giga Pascal \\ $\mathrm{G}_{\mathrm{f}} \quad$ Energia de fratura \\ kN Kilo Newton \\ MPa Mega Pascal \\ $\mathrm{m}^{3} \quad$ Metro cúbico \\ $\mathrm{mm} \quad$ Milímetro \\ $\mu \mathrm{m} \quad$ Micrómetro \\ Sd Desvio Padrão \\ $\mathrm{Vi} \quad$ Volume inicial \\ Vf Volume final \\ ${ }^{\circ} \mathrm{C} \quad$ Grau Celsius \\ pH Potencial hidrogeniônico \\ $\rho_{\text {água }}$ Massa específica da água \\ i Argamassa de traço 1:0 a 1/4:3 \\ ii Argamassa de traço 1: 1/2: 4 a 4 1/2 \\ iii Argamassa de traço 1: 1:5 a 6 \\ iv Argamassa de traço 1:2:8 a 9 \\ $\% \quad$ Porcentagem
}





\section{INTRODUÇÃO}

O desenvolvimento sustentável é definido como um modelo econômico, político, social, cultural e ambiental equilibrado, que satisfaz as necessidades das gerações atuais sem comprometer a capacidade de as gerações futuras satisfazerem suas próprias necessidades (EIRES, 2008). Essa concepção começa a se formar e a se difundir juntamente com o questionamento do estilo de desenvolvimento adotado, que é ecologicamente predatório na utilização dos recursos naturais. Contudo, o desenvolvimento industrial, associado ao crescente consumo, a obsessão pelos combustíveis fósseis como petróleo, carvão e gás natural e o desejo massificado pelo lucro a curto prazo causam uma certa insensibilidade a alternativas mais sustentáveis.

A construção civil transforma entre $14 \%$ a $50 \%$ dos recursos naturais extraídos no planeta, sendo a segunda indústria responsável pela emissão de dióxido de carbono (FIORITI, 2002). Dessa forma, há necessidade de desenvolvimento de materiais alternativos como um novo caminho para a sustentabilidade. Felizmente, verifica-se que gradualmente vai se fomentando a procura desses materiais e maior é a tendência dos pesquisadores de estimularem a busca de novas matérias-primas provenientes de fontes renováveis e menos poluentes.

A pesquisa tem como enfoque fundamental avaliar a viabilidade de se incorporar resíduos no concreto para a fabricação de blocos estruturais. Esses materiais não convencionais são fibras de sisal e pós residuais, provenientes do resíduo orgânico e da exploração de pedreiras, que possibilitam a substituição de cimento e areia.

O interesse por esse tema se deve a trabalhos desenvolvidos por outros pesquisadores que mostraram a viabilidade do uso desses resíduos em substituição parcial ou total em matrizes cimentícias. Também existe a necessidade de se pesquisarem tecnologias alternativas na construção civil, com melhor desempenho ambiental, social, econômico e tecnológico. Nos últimos anos, a economia sustentável a nível mundial tem prosperado significativamente e, cada vez mais, a qualidade de vida das populações pode ser considerada como intimamente relacionada com o uso de produtos alternativos na construção, designados “materiais verdes".

\subsection{Objetivo principal}

O objetivo principal desta pesquisa consiste em avaliar a incorporação pó de resíduo orgânico e pó de pedra em substituição ao cimento e ao agregado miúdo nas propriedades 
físicas e mecânicas de unidades e elementos de alvenaria estrutural e aumentar a durabilidade da fibra de sisal na matriz cimentícia dos blocos.

\subsection{Objetivos específicos}

Já como objetivos específicos podem-se citar:

a) Desenvolver um trabalho teórico-experimental que permita o avanço do conhecimento sobre a utilização de pó de resíduo orgânico, pó de pedra e fibra de sisal na produção de blocos de concreto;

b) Avaliar as propriedades físicas e mecânicas de concretos por meio da fabricação de corpos de prova cilíndricos com os pós residuais incorporados, comparativamente aos valores de referência e determinar as porcentagens adequada de pó de pedra substituindo a areia e do pó de resíduo orgânico substituindo o cimento;

c) Estabelecer critérios para a dosagem de concretos para blocos estruturais utilizando a fibra de sisal e as porcentagens corretas dos pós residuais;

d) Produzir blocos estruturais com classe de resistência de 4, 8 e $12 \mathrm{MPa}$ com adição dos pós residuais e da fibra de sisal;

e) Analisar o desempenho mecânico de blocos, prismas e pequenas paredes com a adição dos pós e da fibra por meio dos ensaios à compressão axial, inclusive com a determinação do módulo de deformação;

f) Aumentar a durabilidade da fibra de sisal na matriz cimentícia e avaliar o desempenho da mesma por meio de ensaios de flexão nos blocos reforçados e observações da matriz em um microscópico eletrônico de varredura.

\subsection{Resultados previstos}

A produção de blocos de concreto estruturais com a combinação de pós-residuais provenientes do resíduo orgânico e da extração mineral e fibras de sisal pode resultar em uma unidade que apresente características mais apropriadas de resistência mecânica, menor consumo de cimento e de areia, maior rigidez, maior ductilidade, maior capacidade de absorção de energia e melhor comportamento pós-fissuração em comparação com os blocos convencionais de concreto. 


\subsection{Justificativas}

O sistema construtivo em alvenaria estrutural tem apresentado um crescimento significativo no Brasil nos últimos anos. A volta da classe $\mathrm{C}$ ao mercado consumidor de imóveis e o empenho da engenharia nacional em se fortalecer no mercado são alguns dos motivos que estão alavancando o uso desse sistema. É por essa razão que o correto uso dos materiais alternativos, como pós residuais e fibra de sisal, nos blocos de concreto será certamente uma solução eficiente, objetiva e economicamente viável.

A seguir são apresentados alguns impactos previstos no âmbito científico, tecnológico, social, econômico e ambiental. Desse modo, pode-se tornar claro o aporte do trabalho comprovando a relevância do estudo.

\subsubsection{Impactos científicos e tecnológicos}

Os pós residuais e o sisal serão aplicados na produção de componentes para a alvenaria estrutural. Consequentemente, existe a necessidade de se investigarem novas soluções tecnológicas referentes a concretos secos que empregam esses materiais não convencionais como substituto de recursos, como o cimento e a areia. É essencial a produção de conhecimento científico relacionado a novos materiais alternativos na construção civil para se alcançarem efetiva contribuição e transferência tecnológica.

\subsubsection{Pó de resíduo orgânico}

Uma das grandes vantagens do pó residual é constituir um material fino que pode ser utilizado como "fíler” no concreto. Dessa forma, os vazios deixados pelos grãos de cimento são preenchidos pelo material fino, contribuindo para um adequado empacotamento do concreto e melhorando as propriedades mecânicas. Por outro lado, pode existir reação pozolânica no concreto, produto da presença de sílica no resíduo. É por essa razão que o material tem potencial para atuar na substituição do cimento, contribuindo para a sustentabilidade da construção civil.

\subsubsection{Pó de pedra}

O pó de pedra tem um diâmetro máximo inferior a $4,8 \mathrm{~mm}$ e pode ser caracterizado como areia média. Constitui um rejeito da exploração de pedreiras, apresentando heterogeneidade granulométrica que pode ser positiva, pois permite o preenchimento completo de vazios e a consequente economia dos agregados. Segundo Menossi (2004), os pós de pedra com porcentagem do material pulverulento variando de $7 \%$ a $20 \%$ colaboram na 
melhoria da aglomeração das partículas maiores do concreto. Dessa forma são evitados concretos pouco trabalháveis, sujeitos a maior exsudação, com grande permeabilidade e muito propícios aos agentes agressivos.

As propriedades físicas e químicas dos agregados e das misturas ligantes são essenciais para a vida útil das estruturas em que são usados. O pó de pedra se torna uma boa alternativa por possuir uma maior uniformidade de propriedades e constituir um material com características físicas e químicas constantes. Também o resíduo possui partículas com formato equidimensionais, melhorando a trabalhabilidade e a resistência à compressão do concreto.

\subsubsection{Fibra de sisal}

A introdução de fibras como reforço no concreto melhora o desempenho mecânico do material. Para alvenaria de blocos de concreto, a ruptura normalmente ocorre devido à tração do bloco para tensões de compressão de pequena intensidade e com tração lateral dominante no estado biaxial. Dessa maneira, a função das fibras nos blocos de concreto é de reforço, permitindo a transferência dos esforços à tração, diminuindo a propagação de fissuras, controlando suas aberturas e retardando a ruptura das unidades.

\subsubsection{Impactos ambientais}

A reciclagem é fundamental para diminuir os impactos ambientais no planeta. Ao reciclar economizam-se recursos naturais não renováveis e energia, geram-se empregos diretos ou indiretos e evita-se o depósito de materiais tóxicos e/ou de difícil decomposição no ambiente. Neste estudo pretende-se diminuir o uso de matérias-primas (cimento e agregados) e reduzir o volume de resíduos sólidos com destinação inadequada.

\subsubsection{Resíduo orgânico}

Atualmente, o resíduo orgânico é considerado poluente e quando acumulado pode tornar-se altamente perigoso, em geral devido ao seu processo de decomposição. Assim, caso não haja um mínimo de cuidado com o armazenamento desses resíduos, cria-se um ambiente propício ao desenvolvimento de micro-organismos que podem ser agentes causadores de doenças.

Além disso, no processo de decomposição do resíduo orgânico é produzido um líquido viscoso de cheiro forte e desagradável denominado chorume, que manejado de forma inadequada pode levar à contaminação do solo e das águas. Na decomposição desses resíduos 
também há a formação de gás metano $\left(\mathrm{CH}_{4}\right)$, que aquece cerca de 23 vezes mais que o gás carbônico $\left(\mathrm{CO}_{2}\right)$ e contribui muito para o agravamento do efeito estufa.

Assim, o resíduo orgânico deve ser depositado em aterros sanitários, seguindo todas as normas de saneamento básico e de tratamento do resíduo. Entretanto, a cada dia que passa, a disponibilidade de espaço para os aterros sanitários é menor, pela grande área necessária. Isso constitui em um grande problema porque implica numa maior distância dos centros urbanos, aumentando consideravelmente o custo de transporte.

A empresa Gold Press Máquinas e Reciclagem Ltda., localizada em Barretos, São Paulo, desenvolveu uma técnica inovadora no país para o tratamento de resíduos orgânicos. É originado ao final do processo um pó residual que pode ser utilizado em materiais da construção civil, substituindo parte do cimento. São produzidas oito toneladas de pó por mês e não existindo um destino adequado, ele é descartado pela falta de utilização.

A preocupação em reduzir o consumo de cimento justifica-se não somente por questões ambientais, técnicas ou econômicas, mas também por questões de sustentabilidade e viabilidade do negócio do cimento. Um aumento do consumo de cimento demanda a abertura de novas unidades fabris que exige não somente grandes investimentos em instalações e equipamentos mas também a concessão e exploração de novas reservas de matérias-primas, cada vez mais difíceis e onerosas devido às crescentes exigências ambientais.

\subsubsection{Pó de pedra}

Uma tendência que vem se consolidando como importante prática de sustentabilidade é a construção com baixo impacto para o meio ambiente que fomente o crescimento das cidades. Atualmente, o pó de pedra não possui valor comercial de mercado, sendo considerado um material marginal, que não possui uma destinação definida, permanecendo estocado no pátio das pedreiras, formando enormes pilhas que provocam vários impactos ambientais, como assoreamento dos rios, poluição visual e gerando, principalmente, muita poeira. O aproveitamento desse resíduo, substituindo parte do agregado miúdo, diminui os danos causados pela exploração indiscriminada da areia presente no leito dos rios. Além disso, a utilização do pó de pedra no concreto elimina um rejeito que, por sua vez, também impacta de forma significativa ao meio ambiente.

\subsubsection{Impactos econômicos e sociais}

Considerando-se os fatores que incidem diretamente na composição dos custos dos materiais de construção (transporte, combustível e produção), os quais elevam 
consideravelmente o valor unitário da construção, a utilização de materiais alternativos produzidos por meio de resíduos disponíveis em grande quantidade e diversidade mostra-se uma alternativa econômica no mercado da construção.

Além disso, a proposição de um novo valor agregado ao resíduo orgânico, pó de pedra e fibra de sisal pode gerar a expectativa de novos postos de trabalho e a criação de um novo nicho econômico para esses resíduos.

\subsection{Metodologia}

Uma revisão bibliográfica foi feita com a finalidade de estudar as características químicas desses resíduos e suas possíveis interações na matriz cimentícia, assim como aspectos de degradação da fibra vegetal em ambientes alcalinos. Diversas pesquisas mostraram resultados satisfatórios que atestam a viabilidade do uso de resíduos em substituição parcial ou total no concreto e argamassa.

Inicialmente foi estudado e caracterizado o sistema utilizado pela Gold Press Máquinas e Reciclagem Ltda. para o tratamento e beneficiamento dos resíduos orgânicos. Também foram analisadas as diversas etapas do processo de obtenção do pó de pedra a partir da trituração da rocha matriz para a obtenção da brita. A coleta do pó foi feita em uma unidade industrial mineradora da região de São Carlos, SP.

Em seguida foi realizada a caracterização química e física do pó residual orgânico. Na primeira foi avaliada a composição química e o tamanho das partículas, por meio do ensaio de espectroscopia de energia dispersiva por raio-X (EDS) e microscopia eletrônica de varredura (MEV), respectivamente. Com a finalidade de verificar se o resíduo é um material inerte e não contaminante, adequado para ser utilizado no concreto, foi realizada a determinação dos metais pesados por meio da técnica analítica de espectrometria de emissão atômica com plasma acoplado indutivamente (ICP - OES). No estudo físico avaliaram-se granulometria, massa específica e módulo de finura.

Com o pó de pedra foram adotados os mesmos procedimentos de caracterização realizados para o agregado graúdo e miúdo utilizados no concreto. Assim, foi determinada a massa específica real e aparente, massa unitária solta e compactada, composição granulométrica e determinação do teor de materiais pulverulentos.

Nas fibras de sisal foi feita a caracterização das propriedades físicas, como massa específica, absorção de água e teor de umidade, visando sua aplicação como reforço de matrizes cimentícias para blocos estruturais de concreto. 
Antes de se proceder à produção dos blocos foi utilizado o método de dosagem do Menor Volume de Vazios para a definição do esqueleto da mistura e determinação da composição ideal dos agregados. Esse procedimento baseia-se na formulação de uma mistura com um mínimo de vazios possíveis, visando alcançar a maior massa unitária. A busca de um menor volume de vazios permite encontrar uma proporção entre os agregados que resulte em uma mistura mais compacta, por essa ter relação direta com a resistência à compressão.

Em um estudo piloto foram produzidos corpos de prova cilíndricos $(5 \mathrm{~cm} \times 10 \mathrm{~cm})$ utilizando-se concreto de consistência seca de característica similar ao empregado nos blocos estruturais. O objetivo foi avaliar as porcentagens de pós residuais que causaram melhor comportamento físico e mecânico do concreto para, segundo os resultados obtidos, procederse à fabricação dos blocos. Foram estudados três traços 1:15, 1:10 e 1:6 (pobre, médio e rico) para produzir blocos estruturais das classes de resistência de 4, 8 e $12 \mathrm{Mpa}$, respectivamente. A primeira finalidade desse estudo foi avaliar a substituição da areia natural por pó de pedra com teores de $0 \%, 20 \%, 40 \%, 60 \%$ e $80 \%$ para cada um dos traços. Foi realizado um estudo estatístico por meio do uso da técnica do Bootstrap para determinar a porcentagem ideal do rejeito de britagem. Com a proporção de pó de pedra que gerou as melhores características físicas e mecânicas na mistura, procedeu-se à fabricação de corpos empregando-se substituição do cimento por pó de resíduo orgânico com teores de 0\%, 5\%, 10\%, $15 \%$ e $20 \%$. O estudo estatístico foi feito novamente para contribuir na tomada de decisões e obter-se a porcentagem de pó orgânico que originou a mistura com melhor comportamento mecânico.

Para este estudo, as propriedades do concreto avaliadas foram coesão, massa específica, índice de vazios, absorção de água e resistência à compressão. Este estudo piloto foi um excelente indicativo das características que serão obtidas nos blocos com e sem adição dos resíduos. Julgou-se fundamental o desenvolvimento de formas cilíndricas de $5 \mathrm{~cm}$ x $10 \mathrm{~cm}$ que possibilitassem uma moldagem rápida e, principalmente, uma desforma precisa e rápida, sem comprometer a integridade do corpo de prova. Além disso, elas permitem a produção de grande quantidade de corpos consumindo-se menos material, sem a necessidade de prensa hidráulica necessária para moldar formas maiores.

Os blocos com a incorporação dos pós residuais e do sisal foram fabricadas no Laboratório de Estruturas da Escola de Engenharia de São Carlos (EESC) da Universidade de São Paulo (USP), por meio do uso de uma vibroprensa corretamente equipada, permitindo, assim, melhor controle no processo de produção. Diferentes séries de blocos foram produzidas, caracterizadas pela porcentagem de pó usada na substituição do cimento e da areia e pelo teor de fibras adicionado em relação ao volume do concreto e ao seu 
comprimento. Após essa etapa, foram analisados os blocos quanto a massa específica, índice de vazios, absorção de água, teor de umidade e resistência à compressão.

Finalizando a fase experimental foram fabricados elementos estruturais, como prismas e pequenas paredes, para a realização de um estudo comparativo de seu desempenho.

Com o objetivo de aumentar a durabilidade da fibra de sisal nos blocos foi estudada a redução da alcalinidade da matriz por meio da adição de $10 \%$ de sílica com relação ao volume de cimento, e o uso do cimento CP III, que apresenta 35\% a 70\% de escória de alto-forno. As unidades reforçadas com fibras de comprimento $20 \mathrm{~mm}$ e teor $1 \%$ com relação ao volume do concreto foram expostas a ciclos de umedecimento e secagem por um período de nove meses. Os resultados de durabilidade foram avaliados por meio de ensaios de resistência à tração indireta dos blocos e por observações da matriz em um microscópico eletrônico de varredura.

Para uma melhor compreensão dos resultados e obtenção de conclusões satisfatórias, foram formulados testes estatísticos que possam contribuir para a tomada de decisões, permitindo uma análise rigorosa da influência da adição dos pós residuais e da fibra de sisal nas propriedades mecânicas dos blocos, prismas e pequenas paredes.

\subsection{Estrutura do texto}

A seguir apresenta-se a ordem e os conteúdos principais que contêm cada um dos diferentes capítulos que constituem esta tese.

No Capítulo 2 é apresentada uma ampla revisão bibliográfica com informações sobre as características, uso e importância de resíduos aplicados na construção civil. Também são mencionados os trabalhos de vários autores que têm desenvolvido pesquisas relacionadas com o tema.

No Capítulo 3 são abordados alguns temas referentes à produção de blocos de concreto, as principais metodologias de dosagem existentes e os mecanismos de ruptura dos blocos, prismas e pequenas paredes.

No Capítulo 4 detalha-se o programa experimental apresentando os materiais e os métodos empregados para se atingir os objetivos propostos.

No Capítulo 5 são mostrados os resultados da caracterização dos pós residuais, da fibra de sisal e dos materiais utilizados para a fabricação dos blocos. Seguidamente são feitas as análises dos ensaios do concreto no estado fresco e endurecido referentes aos corpos de prova cilíndricos. 
No Capítulo 6 são mostrados e analisados os resultados relacionados às unidades e aos elementos de alvenaria (bloco, meio-bloco, prisma e pequenas paredes) feitos com os pós residuais e a fibra de sisal. Também é avaliada a durabilidade da fibra na matriz cimentícia.

No Capítulo 7 são apresentadas as conclusões obtidas da realização da presente pesquisa e se propõem alguns tópicos que permitam a elaboração de trabalhos futuros.

No Apêndice A é detalhada a técnica do Bootstrap que constitui o método estatístico utilizado para a análise dos resultados e no Apêndice B é explicado o procedimento de cálculo para a análise da diferença entre duas médias populacionais com o método do Bootstrap. 



\section{USO DE RESÍDUOS NA CONSTRUÇÃO CIVIL}

A maioria dos problemas ambientais causados pelo homem decorre do uso inadequado do meio ambiente. No processo de obtenção dos recursos necessários para produção de bens de consumo e serviços tem-se a geração de resíduos, os quais não estão mais sendo absorvidos por esse meio. Nos primórdios da humanidade, a população era pequena e o meio ambiente conseguia compensar os impactos sofridos por tal agressão, sendo assim, não ocorriam desequilíbrios ambientais significativos. Entretanto, o cenário atual destaca-se pelo consumo aumentado, principalmente nas últimas décadas, seja pelo próprio crescimento da população, pelos avanços da ciência e/ou expansão da indústria.

Do ponto de vista do desenvolvimento sustentável, a reciclagem de resíduos e subprodutos industriais junto à construção civil apresenta-se como uma opção de grande potencial. Isso se deve ao fato do setor consumir grandes quantidades de materiais e por estar presentes em todas as regiões de qualquer país

Considerando-se os fatores que incidem diretamente nos custos dos materiais de construção (transporte, combustível e produção), os quais elevam consideravelmente o valor unitário da construção, a utilização de materiais alternativos produzidos por meio de resíduos disponíveis em grande quantidade e diversidade mostra-se como um campo vasto para pesquisas de aproveitamento e reciclagem (CINCOTTO, 1988).

\subsection{Utilização de resíduos para fabricação de blocos de concreto: uma opção para a sustentabilidade}

A história da civilização revela que o domínio da tecnologia de reutilização de resíduos esteve presente ao longo dos séculos. Como exemplo, os tijolos, telhas e até argamassas foram utilizados como aterros e adições na execução de paredes maciças no império Grecoromano (SOUTO; VANDERLEI; NUNES, 2010).

É fato que a utilização de materiais reciclados na construção civil apresenta excelentes perspectivas para o futuro sustentável. O emprego de produtos que envolvam baixo consumo de energia no seu processo de obtenção gera menor quantidade de rejeitos e apresentem baixa emissão de poluentes. Em muitos casos têm-se verificado satisfatória viabilidade técnica e econômica para o reaproveitamento imediato desses materiais em blocos de concreto e, as pesquisas têm mostrado ser possível o aproveitamento de diversos materiais antes de serem descartados. 
Trabalhos sobre o emprego de agregados reciclados de construção e demolição no concreto têm trazido grandes avanços na área da reciclagem. Destaca-se a pesquisa desenvolvida por Buttler (2006), que teve como objetivo principal avaliar a incorporação de agregados reciclados em blocos estruturais de concreto para três classes de resistência $(4,5$, 8,0 e 12,0 MPa). De maneira geral, independentemente do grupo de resistência avaliado, todas as unidades com agregados graúdos reciclados cumpriram os requisitos estabelecidos. Já para o estudo econômico, todas as hipóteses atestaram a viabilidade da produção de unidades com agregados reciclados com custos de produção e comercialização inferiores aos das unidades comumente produzidas.

Almeida (2009) estudou a viabilidade para a fabricação de blocos de concreto com função estrutural, com adição do resíduo "carepa de aço", em substituição parcial dos agregados presentes em sua composição. Esse resíduo é proveniente de indústrias siderúrgicas, que muitas vezes se torna um inconveniente para as mesmas, por não possuir uma estocagem adequada, bem como uma destinação correta para esse tipo de resíduo. $\mathrm{O}$ estudo analisou os blocos de concreto fabricados com e sem carepa, para fins comparativos, quanto a sua resistência a compressão. Os testes foram realizados aos 7, 14, 28 e 218 dias de idade objetivando conseguir um material alternativo para a construção civil e potencializando diminuir o consumo de recursos naturais utilizados atualmente na fabricação dos blocos de concreto convencionais. A partir dos resultados obtidos, verificou-se que os blocos de concreto com carepa de aço tiveram melhor desempenho quanto à resistência à compressão em todas as idades ensaiadas, em relação aos blocos convencionais. $\mathrm{O}$ maior benefício que a pesquisa proporcionou em relação ao meio ambiente foi a questão da economia de recursos naturais, que são usados na fabricação dos blocos convencionais, pois com a substituição do pedrisco é possível economizar apenas na fábrica TBS SUL de Charqueadas - RS, por exemplo, o equivalente a aproximadamente 10,9 mil toneladas de pedrisco-ano, recurso natural não renovável.

Lins e Júnior (2014) analisaram o desempenho técnico de blocos vazados de concreto simples para alvenaria, fabricados a partir da reutilização de material oriundo da reciclagem de blocos rompidos em ensaios de resistência à compressão ou com algum dano ou trinca resultante das etapas de produção. A fim de obter um estudo comparativo, foram executados quatro traços experimentais variando a quantidade de resíduo utilizada em cada um deles. Posteriormente a etapa de produção, os blocos foram submetidos a testes laboratoriais onde foi possível analisar o desempenho de cada produto e compará-lo ao produto padrão, por meio de ensaios de resistência à compressão, análise dimensional, absorção e aderência. Além de 
atender os requisitos mínimos diante dos resultados de resistência à compressão, observou-se uma superioridade significativa dos blocos que substituíram na sua composição parte de seus agregados por resíduos, quando comparados aos blocos de traço padrão produzidos pela fábrica de pré-moldados, tendo um aumento que variou de 31 a 56\%. Esse aumento considerável na resistência à compressão está atribuído à teoria inicial de que a não hidratação dos grãos de cimento manteria o material inerte e dessa forma, a partir de sua reutilização, ocorreria a sua hidratação e consequentemente haveria um ganho de resistência. Diante dos resultados obtidos verificou-se, através de uma análise de a economia e a viabilidade da implementação dos processos de reciclagem e reutilização dos resíduos. Foi estimado que 3,3 $\mathrm{m}^{3}$ de resíduos que seriam descartados diariamente, poderiam ser reutilizados, originando por dia, uma média de 400 novos blocos que teriam um custo reduzido de produção de até $40 \%$. Desta forma, estima-se que seriam economizados mensalmente $\mathrm{R} \$ 1.500,00$, que são atualmente utilizados para a retirada e deposição dos resíduos. Estima-se que mensalmente poderiam ser produzidos 10000 blocos provenientes da reutilização dos resíduos, gerando uma economia de $\mathrm{R} \$ 2.200,00$ decorrente da não retirada de resíduos da fábrica e da não utilização de agregados na produção, além de um faturamento de aproximadamente $\mathrm{R} \$ 18.000,00$ proveniente da venda desses blocos.

Fioriti (2002) desenvolveu um estudo para a produção de blocos de concreto sem função estrutural com adição de resíduos de borracha na composição do concreto, sendo os resíduos provenientes da indústria de recauchutagem de pneus. O objetivo é analisar os blocos quanto à característica mecânica de resistência à compressão simples e capacidade de absorção de água, para fins de estudos preliminares onde a intenção futura será obter um material alternativo para a construção civil, contribuindo dessa maneira para a conservação das fontes naturais de materiais convencionalmente utilizados e a proteção ambiental. Os resultados obtidos nos ensaios de resistência à compressão para os blocos acrescidos de $15 \%$ de resíduos de borracha obedeceram a resistência mínima de 2,5 MPa exigida pela NBR 12118: 2013 "Blocos vazados de concreto simples para alvenaria - Métodos de ensaio". Dessa forma, o emprego desse tipo de resíduo pode perfeitamente contribuir para que esse material deixe de ser um problema ambiental e de saúde pública, e passe a ser uma fonte de material alternativo a ser empregado com sucesso na construção civil.

A possibilidade de desenvolver um produto sustentável e de baixo custo que possibilite a redução do descarte de Poliestireno Expandido - EPS (ou Isopor), descartado nos aterros, e o consumo de areia extraída dos rios, motivou ao pesquisador Junior (2013) em realizar um estudo sobre esse tema. O objetivo principal foi desenvolver um bloco de alvenaria de baixo 
custo e sustentável para o segmento da construção civil com a inserção de Isopor descartado e moído e que atenda às especificações técnicas correspondentes. Para valores de resistência à compressão, encontrou-se valores mínimo e máximo de 2,05 $\mathrm{MPa}$ a 4,30 $\mathrm{MPa}$ respectivamente, sendo que a resposta ótima de mistura para maximizar esta característica é de $17 \%$ para cimento, 33\% para areia, 45\% para pedrisco e 5\% para Isopor moído. Quanto ao objetivo de se fabricar um bloco de alvenaria alternativo e com um custo unitário menor que o de um bloco de mercado, pode-se concluir que é possível reduzir o custo com a inserção de resíduo de Isopor moído em sua composição e oferecer uma opção viável de reaproveitamento deste material que possui baixo valor comercial. Comparando-se os valores de custo unitário, o bloco com a inserção de Isopor tem aproximadamente um custo $25 \%$ menor que os blocos convencionais.

Viana e Mattar (2013) analisaram a viabilidade técnica da utilização dos resíduos poliméricos irrecuperáveis de indústrias do segmento de plástico na produção de blocos de concreto. Para alcançar esse objetivo o material foi moído na empresa geradora dos plásticos em estudo e enviado para a produção dos blocos de concreto em empresa especializada no ramo. Logo após, o bloco seguiu para os testes de resistência à compressão, verificação superficial, análise dimensional, absorção de água e lixiviação. Realizados os testes, observou-se que só foram aprovados os tijolos com 5\% de plástico, os quais não apresentaram qualquer problema de estrutura e, portanto, conclui-se como a porcentagem ideal de incorporação deste tipo de material em blocos de concreto. Portanto, benefícios gerados utilizando 5\% de plástico no bloco de concreto são de extrema importância para a sociedade pelo fato da diminuição da quantidade de resíduos que tem que ser depositados nos aterros diminuírem, e também pelo fato que essa alternativa irá gerar mais emprego e renda para toda a sociedade como um todo.

Cruz (2007) investigaram a viabilidade de utilização de resíduos de resina de poliéster insaturado reforçado com fibra de vidro para produção de blocos de alvenaria para a construção civil. Os resíduos utilizados foram obtidos no setor de rebarba de empresas que utilizam a fibra de vidro com resina de poliéster insaturado na fabricação de seus produtos. $\mathrm{O}$ melhor resultado encontrado no trabalho foi aquele cuja composição apresentou $5 \%$ de resíduo triturado em substituição em massa na areia. Pela análise estatística ANOVA foi mostrado que estas composições não possuíram diferença significativa. A análise de custos mostrou que a utilização deste material na produção de blocos pode produzir vantagens financeiras tanto para a empresa produtora dos blocos, quanto para a empresa geradora dos resíduos. 
Para se realizar uma pesquisa sobre o uso de pós-residuais e fibras de sisal para fabricação de blocos estruturais de concreto faz-se necessário um amplo estudo englobando a geração dos resíduos, principais características, vantagens da adição no concreto e consultas de publicações sobre o tema tratado. Também devem ser analisadas as diferentes metodologias de dosagem dos blocos e produção de concreto com pós-residuais e fibras de sisal.

\subsection{Definição e características do resíduo orgânico, pó de pedra e fibra de sisal.}

\subsubsection{Resíduo orgânico}

O Brasil produz 241614 toneladas de resíduo por dia, dos quais 76\% são depositados a céu aberto, em lixões, 13\% são depositados em aterros controlados, 10\% em usinas de reciclagem e $1 \%$ são incinerados. Do total do resíduo urbano, $60 \%$ são formados por resíduos orgânicos. É definido como resíduo orgânico todo resíduo de origem vegetal ou animal originário de um ser vivo. Podem ser citados como exemplos de resíduo orgânico os restos de alimentos (carnes, vegetais, frutos, cascas de ovos), papel, madeira, ossos, sementes, etc (JERONIMO; SANTIAGO, 2012). Segundo Siddique (2010), esse tipo de resíduo precisa ser tratado com todo cuidado porque pode gerar consequências indesejadas para os seres humanos. Atualmente, um dos maiores problemas ambientais enfrentados pelo homem constitui o depósito dos resíduos em áreas que são cada dia mais difíceis de serem encontradas, principalmente junto às grandes cidades.

A população pode contribuir para o tratamento do resíduo orgânico favorecendo a coleta seletiva e a reciclagem. Esse tipo de resíduo pode ser usado para a produção de energia (biogás), já que em seu processo de decomposição é gerado o gás metano (GARCEZ; GARCEZ, 2010). Outra utilidade do resíduo orgânico é a produção de adubo orgânico, muito usado na agricultura por meio do processo de compostagem (JAHNEL; MELLONI; CARDOSO, 1999).

Por outro lado, uma solução inovadora no tratamento de resíduos orgânicos é a decomposição por meio de reações químicas. O resultado deste processo é um pó fino e inerte que pode ser usado na construção civil, dando origem a uma tecnologia ecologicamente correta que contribui para um desenvolvimento sustentável.

A maioria das pesquisas que tratam da utilização do resíduo orgânico estão direcionadas à compostagem para seu uso como adubo e geração de energia por meio do gás metano. Não existe atualmente estudo sobre a utilização de pó residual orgânico em materiais da 
construção civil, apresentando originalidade no tema abordado e grandes vantagens, como a reciclagem do resíduo orgânico, a utilização de um material inerte e a redução do consumo de cimento no concreto.

\subsubsection{Pó de pedra}

A NBR 9935: 2011 “Agregados - Terminologia” define o agregado como o material granular pétreo, sem forma ou volume definido, a maioria das vezes quimicamente inerte, obtido por fragmentação natural ou artificial, com dimensões e propriedades adequadas a serem empregados em obras de engenharia.

Os agregados são as substâncias minerais mais consumidas na indústria da construção civil e, portanto, as mais significativas em termos de quantidades produzidas no mundo (LEE et al., 2008). A mineração de areia e brita está espalhada por todo o Brasil e constitui uma das atividades extrativas mais importantes do setor mineral brasileiro devido ao volume produzido. Em 2010, cerca de 289 e 192 milhões de toneladas de areia e brita, respectivamente, foram produzidas pelo país (CEE/CBIC, 2011).

O pó de pedra é o rejeito da exploração de pedreiras e em função da sua curva granulométrica pode-se caracterizar como sendo uma areia média e grossa. $\mathrm{Na}$ atualidade esse resíduo tem sido utilizado na confecção de concretos com finalidade estrutural para a fabricação de blocos de concreto, de camadas de sub-base asfáltica e de camadas de concreto compactado a rolo (CCR) (KARAKUS, 2011). O pó de pedra é considerado um resíduo que fica estocado nos pátios das pedreiras formando enormes volumes e causando danos ambientais, como mostra a Figura 2.1.

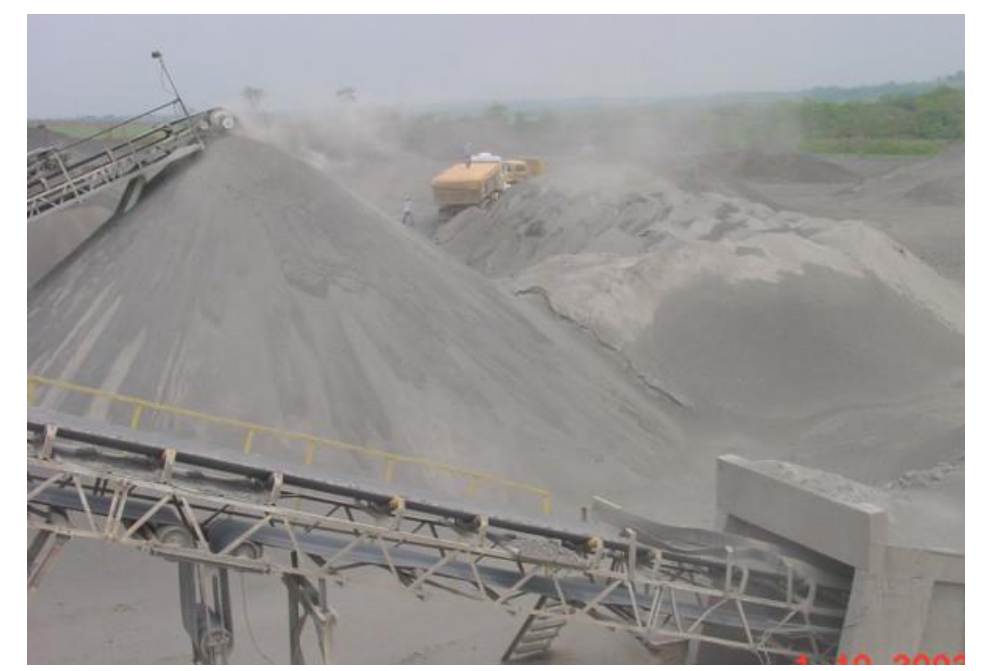

Figura 2.1 - Pó de pedra no pátio da pedreira ao ar livre (Fonte: Menossi, 2004) 
A constante preocupação com a preservação do meio ambiente tem incentivado a busca de diversas alternativas para a substituição de agregados naturais e também para a incorporação de certos rejeitos industriais na confecção de argamassas e concretos. A escassez de areia natural é um fato que, hoje em dia, preocupa as indústrias do meio concreteiro, que buscam, cada vez mais, uma melhor qualidade associada à produtividade. Além disso, a retirada de areia de um rio agride sua calha natural, leva a um aumento da vazão de água e acelera o ritmo de erosão das margens. Neste contexto, o aproveitamento do rejeito da britagem das rochas (pó de pedra) como substituição ao agregado miúdo constitui uma alternativa interessante.

\subsubsection{Fibra de sisal}

O sisal (Agave sisalana, família Agavaceae) é uma planta originária do México que se espalhou rapidamente para outras regiões do mundo, como a África, Europa e Ásia. Essa planta é resistente ao clima seco, ao sol intenso e é cultivada em regiões tropicais e subtropicais (Figura 2.2). A fibra de sisal é extraída das folhas que, após o beneficiamento, é destinada majoritariamente à indústria de cordoaria e artesanato(SOTO; RAMALHO, 2012). Cerca de 4,5 milhões de toneladas de fibra de sisal são produzidas a cada ano em todo o mundo sendo a Tanzânia e o Brasil os principais países produtores (LI; MAI; YE, 2000).

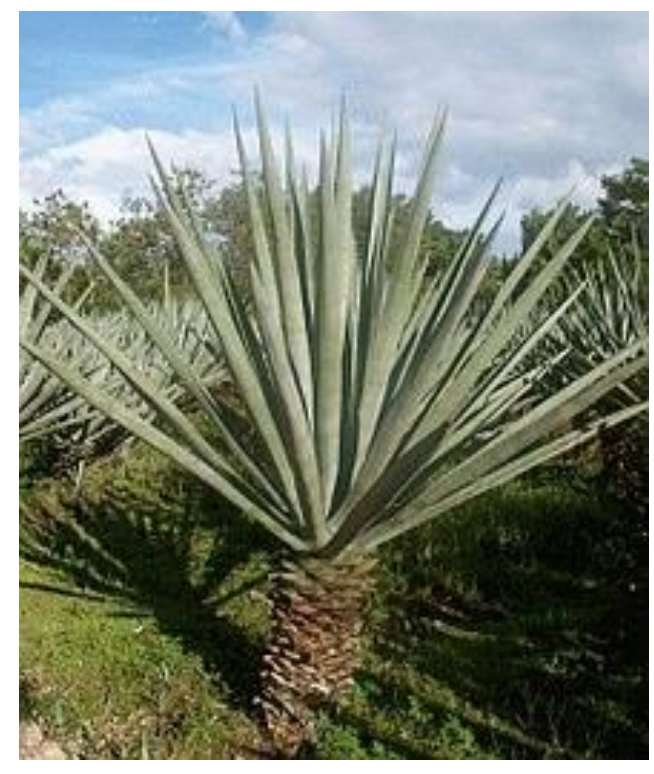

Figura 2.2 - Planta do sisal (Fonte: http://www.sisalrugs.co.uk).

Com relação à microestrutura da fibra, a mesma é formada por várias células individuais (microfibras) unidas umas às outras por meio de lamelas intermediárias, constituídas de hemicelulose e lignina, conforme ilustra a Figura 2.3 (PICANÇO, 2005). 


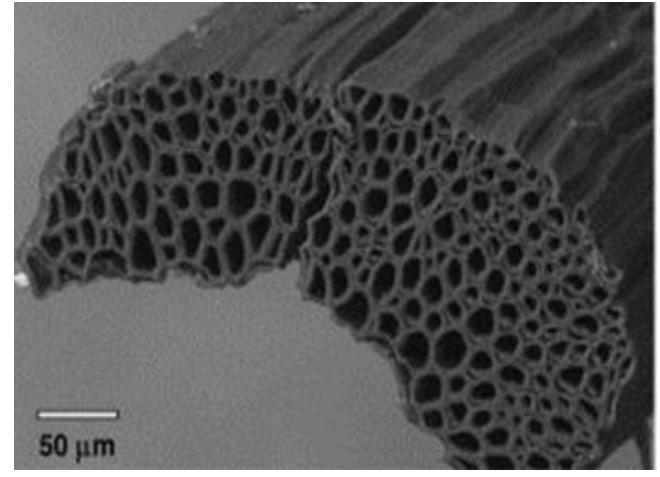

(a)

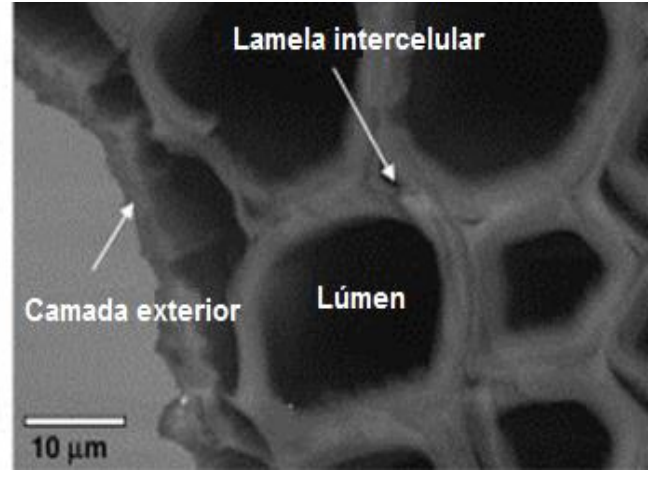

(b)

Figura 2.3 - Morfologia da fibra de sisal: (a) fibra composta por células individuais ligadas pela lamela intercelular e (b) detalhe da célula individual (Fonte: Silva et al., 2010).

A Figura 2.4 apresenta um esquema de uma célula individual, na qual se observa as camadas primária e secundária, sendo esta última dividida em três subcamadas (S1: camada exterior, S2: camada média e S3: camada interna). No meio da célula existe o lúmen, um espaço vazio que influencia no desempenho mecânico das fibras. Dessa forma, em compósitos com matriz cimentícia, substâncias agressivas costumam penetrar causando degradações dos componentes da fibra. Esses compostos podem ainda sofrer cristalização nessa cavidade central e nos demais vazios das fibras, causando enrijecimento desse reforço e sua consequente fragilização (PERSSON, 2000).

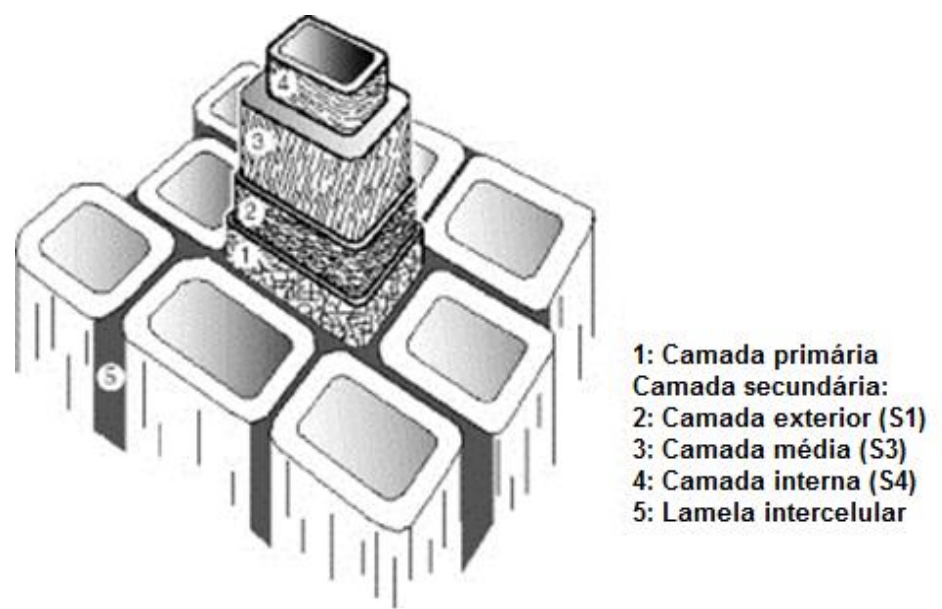

Figura 2.4 - Estrutura celular da fibra de sisal (Fonte: Persson, 2000).

A composição química das fibras de sisal foi relatada por vários pesquisadores. Rowell, Schultz e Narayan (1992) descobriram que o sisal contém 43-56\% de celulose, 7-9\% de lignina, 21-24\% de pentosano e 0,6-1,1\% de cinzas. Joseph, Thomas e Pavithran (1996) relataram que contém 85-88\% de celulose. Milanese, Cioffie e Voorwald (2012) indicaram um conteúdo de $60-80 \%$ de celulose, 5-20\% de lignina e 5-20\% teor de umidade. Por outro lado, Mohan e Kanny (2012) concluíram que as fibras de sisal possuem 65\% de celulose, 12\% 
de hemicelulose, $10 \%$ de lignina e uma pequena quantidade de outros compostos solúveis em água. Essas variações na composição química da fibra de sisal são resultado das diferentes fontes, idades e métodos de medição.

A celulose é um polímero que contém unidades de glucose com microfibrilas de estrutura bem ordenada. A hemicelulose é um grande grupo de polissacáridos presentes nas paredes primárias e secundárias da fibra. Já a lignina é uma mistura amorfa e heterogênea de polímeros e monômeros aromáticos de propano fenílicos. As propriedades mecânicas e físicas das fibras vegetais são primariamente governadas por essas três componentes (JOHN et al., 2005).

O sisal é uma fibra natural que apresenta várias vantagens, entre elas sua facilidade de cultivo, o fato de ser um material biodegradável que provém de fonte renovável, além de apresentar boas propriedades como isolante térmico e acústico. Esses fatores, aliados à alta tenacidade, resistência à abrasão e ao baixo custo, tornam o sisal uma das fibras naturais mais estudadas e utilizadas (REIS, 2012). Seu principal uso é na indústria naval e agrícola em cordas e fios; e também no artesanato para confeccionar tapetes, redes de pesca, bolsas, sacos e alguns tipos de tecidos. Recentemente tem sido aplicado na indústria automobilística, na área de revestimento interno de automóveis, ônibus e caminhões; e na indústria aeroespacial, esporte e embalagem, constituindo um mercado em expansão (RAMIRES et al., 2010). Durante as duas últimas décadas, as fibras de sisal também têm sido usadas como reforço em compósitos à base de cimento e de polímeros, como relatam os trabalhos de Silva e Toledo (2008), Oksman et al. (2002), Toledo et al. (2003), Savastano et al. (2009), entro outros. Tais compósitos são considerados atualmente um dos materiais estruturais mais promissores em tecnologias de engenharia sustentável.

Devido à grande incidência de poros permeáveis, que incluem as lacunas e os lúmens, as fibras vegetais, e consequentemente, as fibras de sisal, possuem massa específica aparente inferior à real e apresentam grande absorção de água (maior que 90\%), situação que afeta o grau de aderência com a matriz cimentícia (SILVA; MOBASHER; SORANAKOM, 2011). Por outro lado, possuem alta resistência à tração e baixo módulo de deformação com grandes mudanças em sua secção transversal, ao longo do comprimento (THOMASON et al., 2011).

A Tabela 2.1 apresenta as propriedades físicas e mecânicas da fibra de sisal segundo vários pesquisadores. 
Tabela 2.1- Propriedades físicas e mecânicas da fibra de sisal (Fonte: autor).

\begin{tabular}{|c|c|c|c|c|c|c|c|c|}
\hline Fonte & $\begin{array}{c}\text { Umid. } \\
(\%)\end{array}$ & $\begin{array}{c}\text { Massa } \\
\text { esp. real } \\
(\mathrm{kg} / \mathrm{m3})\end{array}$ & $\begin{array}{l}\text { Massa } \\
\text { esp. } \\
\text { aparen. } \\
(\mathrm{kg} / \mathrm{m} 3)\end{array}$ & $\begin{array}{c}\text { Vol. de } \\
\text { vazios } \\
\text { perm. } \\
(\%)\end{array}$ & $\begin{array}{l}\text { Abs. } \\
\text { máx. } \\
24 \text { h } \\
(\%)\end{array}$ & $\begin{array}{c}\text { Alongam. } \\
\text { na rupt. } \\
(\%)\end{array}$ & $\begin{array}{c}\text { Resist. à } \\
\text { tração } \\
\text { (MPa) }\end{array}$ & $\begin{array}{c}\text { Mód. de } \\
\text { elastic. } \\
\text { (GPa) }\end{array}$ \\
\hline \multicolumn{9}{|l|}{ Toledo } \\
\hline $\begin{array}{l}\text { Filho } \\
(2003)\end{array}$ & 14,6 & 1100 & 760 & - & 193 & $7,7-3,6$ & $535-539$ & - \\
\hline $\begin{array}{c}\text { Savastano } \\
(2009)\end{array}$ & - & 1370 & 564 & 60,9 & 110 & $4,9-5,4$ & $347-378$ & 15,2 \\
\hline $\begin{array}{l}\text { Silva } \\
(2010)\end{array}$ & - & 1387 & 400 & 72,4 & 151 & - & - & - \\
\hline $\begin{array}{c}\text { Thomason } \\
\text { (2011) }\end{array}$ & - & - & - & - & - & 4,3 & 458 & 15,2 \\
\hline
\end{tabular}

A perda de ductilidade em meio úmido e alcalino, a elevada absorção de água e a heterogeneidade de suas propriedades físicas e mecânicas são os fatores mais importantes que interferem negativamente no desempenho das fibras vegetais, quando aplicadas para reforço de matrizes à base de cimento Portland. Apesar disso, apresentam outras vantagens que interferem no bom desempenho do compósito possibilitando uma maior absorção de energia, maior tenacidade, maior ductilidade e capacidade de absorver carregamentos após a fissuração. Tais materiais poderão ser utilizados em estruturas para resistir intensas ações de vento, terremotos, impactos de objetos e em paredes de alvenaria não armada. Esses aspectos poderão ser bem explorados com o desenvolvimento de técnicas de produção e de conservação dos compósitos fibrosos.

\subsection{Utilização de pó de resíduo orgânico, pó de pedra e fibra de sisal na construção civil}

Existem diversas pesquisas sobre o uso de pó de resíduo orgânico, pó de pedra e fibra de sisal na construção civil que mostram resultados satisfatórios obtidos pelos pesquisadores e atestam a viabilidade do uso em substituição parcial ou total em matrizes cimentícias.

\subsubsection{Pó residual orgânico}

A disposição nos aterros tem sido o método simples e barato para o descarte de resíduos sólidos urbanos. No entanto, esta solução tem causado problemas ambientais, como poluição das águas subterrâneas e a emissão de odor e contaminação do solo. Do mesmo modo, espaços para aterros são cada vez mais limitados, especialmente em países com uma grande população (SAIKIA, KATO E KOJIMA, 2007). Além disso, existem outros métodos para o 
tratamento de resíduos sólidos como a incineração, reciclagem de materiais reutilizável e decomposição química em resíduos orgânicos.

Uma solução viável no gerenciamento do resíduo nos países desenvolvidos e industrializados é a incineração de resíduos sólidos urbanos (RSU). Zanta e Ferreira (2003) definem resíduos sólidos urbanos como sendo os materiais resultantes das inúmeras atividades desenvolvidas em áreas com aglomerações humanas, abrangendo resíduos de várias origens, como residencial, comercial, de estabelecimentos de saúde, industriais, da limpeza pública, da construção civil, os agrícolas, incluindo os resíduos orgânicos. O processo de incineração dos RSU é considerado uma forma moderna, cara e racional de reduzir o volume de resíduo em cerca de 90\%, eliminando as emissões de metano, diminuindo a demanda de espaço para aterramento e gerando energia elétrica.

A porcentagem de RSU incinerado na Europa tem crescido cerca de 15\% em 1995 para $20 \%$ em 2009 (GORI et al., 2012). No Japão, cerca de 80\% dos RSU é incinerado e reutilizado (JUNG et al., 2004). Na China, a cada ano são construídas plantas de incineração de resíduos sólidos em cidades, como Shenzhen, Pequim e Xangai para a geração de energia elétrica (CHENG; HU, 2010). Países como Bélgica, Holanda, Alemanha e França estabeleceram critérios para a utilização do resíduo urbano incinerado na construção civil, por meio de leis e regulamentos (VAN GERVEN et al., 2005). Em países altamente povoados, como a Índia, Turquia e México, a maioria dos resíduos sólidos é geralmente destinada a aterros e lixões (LINO; ISMAIL, 2012).

No Brasil, atualmente, a incineração é utilizada somente para resolver a questão da disposição final de resíduos perigosos e parte dos resíduos hospitalares. No entanto, essa tecnologia utilizada atualmente no país não faz uso do aproveitamento energético. Para isso seriam necessários alguns aprimoramentos tecnológicos para permitir esse aproveitamento de forma economicamente viável e ambientalmente correta.

O subproduto do processo de incineração é a cinza, equivalente a 2-5\% dos resíduos urbanos. Dessa forma, são produzidos anualmente grandes quantidades de cinza incinerada, sendo necessário buscar um destino adequado. É por essa razão que vários pesquisadores dos países industrializados têm desenvolvido trabalhos sobre o uso desse material como matéria prima. Segundo Ferreira, Ribeiro e Ottosen (2003), existem nove possíveis aplicações para as cinzas provenientes da queima dos RSU, que são agrupadas em quatro categorias principais. São elas: materiais para a construção civil (cimento, concreto, cerâmica, vidro e vidrocerâmica), aplicações na geotenia (estradas pavimentadas e aterros), agricultura (alteração do solo) e diversos (absorventes e condicionamento de lodo). 
Em geral, a caracterização química e física das cinzas dependerá das composições do resíduo sólido. O mesmo varia ao longo do tempo e de país para país devido às diferenças no estilo de vida e nos processos de reciclagem do resíduo (HE et al., 2004). Apesar disso, Zhang et al. (2008) mostraram que os elementos mais comum na composição química são silício $(\mathrm{Si})$, alumínio $(\mathrm{Al})$, ferro $(\mathrm{Fe})$, magnésio $(\mathrm{Mg})$, cálcio $(\mathrm{Ca})$, potássio $(\mathrm{K})$, sódio $(\mathrm{Na})$ e cloro (Cl). Além disso, $\mathrm{SiO}_{2}, \mathrm{Al}_{2} \mathrm{O}_{3}, \mathrm{CaO}, \mathrm{Fe}_{2} \mathrm{O}_{3}, \mathrm{Na}_{2} \mathrm{O}, \mathrm{K}_{2} \mathrm{O}$ são os óxidos mais representativos e, portanto, pode ser utilizada como substituição no cimento. Dessa forma, vários pesquisadores estudaram o uso deste resíduo na produção do concreto como Rémond, Pimienta e Bentz (2002), Lin et al. (2004), Singhal, Tewari e Prakash (2008), Siddique (2010), Chen, Ma e Dai (2010); Rodriguez et al. (2011).

Al-Amoudi, Maslehuddin e Asi (1996), por exemplo, fabricaram concretos com substituição, em peso, do cimento pelas cinzas provenientes da incineração do resíduo urbano. Os teores de substituição foram $0 \%, 10 \%, 20 \%, 30 \%$ e $40 \%$ e a relação a/c variou entre 0,35 , $0,45,0,50$ e 0,55 . As propriedades avaliadas do concreto foram resistência à compressão, porosidade e permeabilidade depois de 28, 90, 180 e 360 dias. Segundo os resultados obtidos, a porosidade e a permeabilidade do concreto de referência foi menor do que o concreto com adição da cinza no período de 50 a 75 dias. Depois desse período, as amostras com cinzas foram menos permeáveis que o concreto padrão em $30 \%$. Em relação à resistência à compressão dos corpos de prova de referência observou-se que a mesma foi maior até 180 dias. No entanto, uma reversão dessa tendência foi observada após este período para os concretos com adição da cinza com um aumento de 7\%. Os autores atribuem essa melhoria devido à reação pozolânica que deve ter ocorrido na matriz cimentícia. Dessa forma, o comportamento físico e mecânico do concreto analisado durante o tempo foi otimizado devido à maior formação de silicatos de cálcio hidratados (S-C-H). O melhor desempenho foi observado no concreto com $20 \%$ de substituição do cimento pelo resíduo.

Al-Rawas et al. (2005) utilizaram cinzas provenientes da incineração por areia e cimento na produção de concretos. Foram empregados teores de substituição de 0\%, 10\%, $20 \%$ e $30 \%$ e uma relação a/c constante igual a 0,70. Os resultados mostraram que os exemplares com $20 \%$ de substituição de areia por cinzas apresentaram o maior valor de resistência à compressão aos 28 dias $(36,4 \mathrm{MPa})$, um aumento de $17 \%$ em relação às amostras de referência. O concreto produzido com substituição de $30 \%$ mostrou um aumento pouco significativo em relação ao exemplar com 20\%, o que levou os autores a concluir que, economicamente e tecnicamente, o valor de $20 \%$ é o mais indicado para o traço utilizado. 
Ferraris et al. (2009) também estudaram o pó proveniente da incineração do resíduo sólido urbano na produção de concretos e argamassas. Como pré-tratamento, a cinza foi aquecida a uma temperatura de $1450{ }^{\circ} \mathrm{C}$ e transformada em cinza volante vitrificada (CVV). Esse resíduo foi utilizado como fíler $(<50 \mu \mathrm{m}$ ou $<90 \mu \mathrm{m})$, substituindo parte do cimento, e como agregado fino (5-10 $\mathrm{mm}$ e 10-20 mm), substituindo parte da areia. Os teores utilizados foram $0 \%, 25 \%, 50 \%, 75 \%$ e $100 \%$, em volume, com relação a/c igual a 0,60 para a produção de argamassas e concretos. Os resultados mostraram que o fíler com substituição de até $20 \%$ em peso não afetou a resistência à compressão do concreto depois de 150 dias. Do mesmo modo, a CVV como agregado fino pôde substituir à areia entre 50-75\%, devido ao fato da coesão entre a superfície do vidro plano e da matriz de cimento não afetar significativamente o comportamento mecânico das amostras.

Muller e Rubner (2006) estudaram a microestrutura do concreto usando como agregados as cinzas do resíduo urbano e determinaram as reações que ocorrem com a matriz cimentícia. As cinzas foram coletadas em uma usina de incineração no norte da Alemanha. Ela estava constituída por $80 \%$ de vidro, metais, cerâmica e madeira e $20 \%$ de resíduos orgânicos. Os componentes principais eram silicatos cristalinos, aluminatos e óxidos. A reação do alumínio com a pasta de cimento foi expansiva, dando lugar ao hidróxido de alumínio e provocando a danificação da superfície do concreto. A análise microestrutural das amostras indicou uma clara formação de gel sílico-alcalino que preencheu os poros e espaços vazios do concreto sem exercer pressão sobre o material.

A partir do ano 2000, a reutilização de resíduos urbanos como matérias-primas na fabricação de cimento tem sido investigada substancialmente por vários pesquisadores. Destaca-se a pesquisa realizada por Wu et al. (2012) que avaliaram a substituição das cinzas incineradas na produção de cimento Portland por meio da difração de raios X, espectrometria de fluorescência de raios $\mathrm{X}$ e microscopia eletrônica de varredura. Os resultados experimentais mostraram que o clínquer de boa qualidade pode ser obtido por aquecimento das misturas em bruto a $1200^{\circ} \mathrm{C}$ durante $2 \mathrm{~h}$ com substituição da cinza provenientes da incineração dos resíduos sólidos urbanos em um 30\%. Foi observado também que os metais pesados tais como cromo, chumbo, cádmio, zinco e níquel são presos no clínquer e bem fixados pelos produtos de hidratação, não apresentando um risco de lixiviação para o meio ambiente. 


\subsubsection{Pó de pedra}

O uso de pó de pedra na construção civil tem sido investigado com êxitos por vários autores, servindo assim de embasamento para o desenvolvimento de futuras pesquisas. Dessa forma, busca-se a consolidação desse produto na produção de elementos estruturais.

Barbosa et al. (2004) desenvolveram uma pesquisa para o estudo de composições de concretos auto-adensáveis (CAA) com incorporação de pó de pedra. Foram realizados inicialmente ensaios similares aos tradicionais para CAA, em modelos reduzidos para SlumpFlow, Funil em V e Caixa em L, a fim de analisar uma composição ótima da pasta, buscando o ponto de saturação dos aditivos e a influência do pó utilizado. Posteriormente as composições selecionadas na primeira fase foram submetidas a ensaios em escala natural para a definição das propriedades mecânicas do concreto. $\mathrm{O}$ concreto produzido com pó de pedra atingiu resistência à compressão aos 28 dias superior a $60 \mathrm{MPa}$, para um consumo de cimento de $300 \mathrm{~kg} / \mathrm{m}^{3}$ e fator a/c de 0,65 . As misturas de concretos auto-adensaveis verificadas neste estudo mostraram que o resíduo oferece um correto desempenho com os diferentes materiais empregados.

Saboya, Xavier e Alexandre (2007) adicionaram o pó de pedra na matéria prima de argila para a fabricação de tijolos cerâmicos. As unidades foram produzidas em uma máquina extrusora laboratorial simulando, assim, o processo industrial real. Estas amostras foram moldadas com diferentes teores de pó variando a temperatura entre $750-950{ }^{\circ} \mathrm{C}$ com o objetivo de verificar as possíveis modificações nas propriedades mecânicas. Os resultados mostraram que a utilização de $15 \%$ e $20 \%$ de teor de pó pode ser considerada a melhor porporção. No entanto, a absorção de água é uma das propriedades mais críticas para o tijolo cerâmico, e os valores com $20 \%$ de resíduos foram mais elevados do que o permitido para fins da construção civil. Assim, uma composição de matéria-prima argilosa com 15\% do teor de pó a $850{ }^{\circ} \mathrm{C}$ pode ser usado em escala industrial para a utilização comercial do corpo cerâmico.

Aruntas et al. (2010) utilizaram o pó de pedra como adição na fabricação do clínquer de cimento Portland. Foram empregados teores de pó de 2,5\%, 5,0\%, 7,5\% e $10 \%$ em peso e foram produzidos corpos de prova de argamassa com dimensões de $40 \times 40 \times 160 \mathrm{~mm}$. Os ensaios de resistência à compressão forma realizados aos 7, 28 e 90 dias. Os resultados mostraram que um $10 \%$ de resíduo pode ser usado como adição na produção de cimento devido a que a resistência à compressão das amostras foi superior nas três idades estudadas em um $5 \%$. 
Karakus (2011) estudou o pó de pedra como adição no concreto asfáltico para a construção de estradas. Os ensaios foram realizados em rodovias suportando cargas pesadas de tráfego com o objetivo de avaliar a deformação, durabilidade e fissuras do concreto. Foi concluído que misturas com adição de resíduos da exploração de pedreiras para a fabricação de estradas tiveram uma maior resistência à abrasão, maior conforto, durabilidade e menor permeabilidade. Os custos de produção e manutenção foram potencialmente reduzidos devido a aplicação 667875 toneladas de pó de pedra em uma estrada de $325 \mathrm{~km}$ de comprimento e $22 \mathrm{~m}$ de largura.

Menossi (2004) fez um estudo da substituição da areia natural existente no concreto pelo pó de pedra. Foram confeccionados corpos de prova utilizando cinco traços diferentes, de modo que a areia natural foi gradualmente substituída pelo pó de pedra nas proporções de $25 \%, 50 \%, 75 \%$, e $100 \%$. O concreto com $50 \%$ de adição de pó de pedra apresentou um acréscimo de resistência à compressão axial em um 53\% em comparação com o concreto produzido com areia natural. Com relação à trabalhabilidade, o concreto com pó de pedra sem aditivo exigiu uma demanda maior de água para que pudesse apresentar um mesmo abatimento que um concreto produzido com areia natural. De forma geral, foi comprovado que o pó de pedra é um material alternativo à areia natural, pois apresentou todos os requisitos necessários a um agregado miúdo e melhorou significativamente a maioria das propriedades do concreto.

Silva, Buest e Campiteli (2005) avaliaram a substituição de areia natural pelo pó de pedra em argamassas de revestimento e assentamento. Aos 28 dias de idade as argamassas feitas com $100 \%$ de pó de pedra obtiveram o maior resultado, com um valor de resistência a compressão igual a 3,51 MPa, superando em um 15\% a amostra de referência. Por outro lado, as argamassas com adição do resíduo de britagem foram 5\% menos impermeáveis com relação às argamassas com $100 \%$ de areia. Mesmo assim, foram obtidos vários benefícios, como o aproveitamento sustentável desse resíduo, diminuição do uso de agregados naturais e melhor comportamento mecânico das argamassas.

Silva (2012) estudou a substituição de cimento e a areia pelo rejeito de britagem para a produção de argamassas visando à produção de telhas. Com relação à resistência à compressão, foi constatado que houve uma queda de desempenho quando adicionou-se o pó de pedra tanto com quanto sem o aditivo plastificante, porém os valores apresentam-se acima dos $250 \mathrm{Kgf}$ definido como limite mínimo por norma. 
Marques e Campos (2012) abordaram a substituição da areia natural pelo pó de pedra, analisando suas influências em argamassas de revestimento e assentamento, tal como a resistência à compressão, a impermeabilidade, o fator econômico e ecológico. A partir da avaliação dos resultados de resistência à compressão foi concluído que as argamassas confeccionadas somente com pó de pedra obtiveram melhores resultados se comparadas com as demais. Isso mostra que a substituição do agregado miúdo natural pelo artificial (pó de pedra) é viável do ponto de vista mecânico. No ensaio de absorção de água, os corpos de prova confeccionados com $100 \%$ de pó de pedra obtiveram maior absorção se comparado com as argamassas sem pó de pedra e com as argamassas com 50\% de pó de pedra. Esse resultado deve-se à alta relação água/cimento que deixa a argamassa mais porosa com esse material. Muitos benefícios foram obtidos dentre eles estão: o modo sustentável de aproveitamento desse material, a diminuição do uso de agregados naturais, uma maior resistência nas argamassas de revestimento e uma economia maior nos gastos de água, já que por sua vez, as argamassas feitas com o pó de pedra ficaram mais fluidas que as argamassas comuns.

Nunes Junior (2013) avaliou a substituição da areia pelo pó de pedra nos teores de 0, 50 e $100 \%$ para a fabricação de argamassas e foram comparadas com a argamassa industrializada utilizada em obras de alvenaria estrutural. A resistência à compressão e o módulo de elasticidade foram consideravelmente maiores na argamassa com substituição de $50 \%$ de pó de pedra em comparação a argamassa industrializada. Os resultados mostram que as argamassas compostas por pó de pedra apresentam uma alternativa viável com vantagens técnicas do aumento da resistência à compressão das argamassas e dos prismas de blocos estruturais. E também uma alternativa para as questões ambientais que envolvem as areias convencionais.

\subsubsection{Fibra de sisal}

A utilização de fibras vegetais como reforço constitui um grande interesse na obtenção de novos materiais para a construção civil em razão de seu baixo custo, alta disponibilidade e reduzido consumo de energia para sua produção. As principais finalidades de se reforçar a matriz frágil de cimento com fibras são: aumento das resistências à tração e ao impacto, maior capacidade de absorção de energia e possibilidade de uso no estagio pós-fissurado.

Segundo Mehta e Monteiro (2008), a história da utilização de compósitos reforçados com fibras como materiais de construção tem mais de 5000 anos. Existem evidências de que foram utilizadas fibras de asbesto e crina de cavalo para reforçar potes de argila e materiais 
cimentícios. Os egípcios usavam palha para reforçar tijolos de barro. Já Persas usavam as fibras associadas ao solo para construções de habitações, resultando em paredes com bom isolamento térmico e boa aparência estética.

A pesquisa realizada por Silva, Mobasher e Toledo (2009) demostrou as vantagens das fibras de sisal como reforço no concreto. Segundo eles, os elementos compósitos com esse tipo de fibra constitui uma nova classe de materiais sustentáveis para a construção, apresentando elevadas resistências à tração e alta ductilidade. O sisal atua como ponte de transferência dos esforços para a matriz cimentícia, diminuindo a propagação de fissuras, controlando suas aberturas e podendo retardar a ruptura dos elementos de concreto.

Nessa pesquisa foi estudada a resistência à tração e à flexão de corpos de prova de concreto com medidas de $400 \times 50 \times 12 \mathrm{~mm}$ (comprimento $\times$ largura $\times$ espessura) e adição de $10 \%$ de fibras em volume de concreto. A formação e abertura das fissuras foram avaliadas por meio de imagens de alta resolução. Os resultados mostraram que a resistência à tração máxima foi de $12 \mathrm{MPa}$ e o módulo de elasticidade foi de 34,17 GPa, valores superiores em 1,53\% com relação aos corpos de prova de referência. A elevada capacidade de absorção de energia do sistema se refletiu nos altos valores de tenacidade de 45 e $22 \mathrm{~kJ} / \mathrm{m}^{2}$ para a tração e a flexão, respectivamente. Desse modo foi demostrado que as fibras foram capazes de unir as faces das fissuras, conferir certo carregamento após a fissuração e aumentar a energia absorvida, incrementando a tenacidade e ductilidade dos compósitos.

Soto e Ramalho (2012) avaliaram a incorporação de fibras de sisal com comprimento de 20 e $40 \mathrm{~mm}$ e fração volumétrica de 0,5 e $1 \%$, em concretos para a alvenaria de blocos estruturais e determinaram o uso dessas unidades na construção de prismas e pequenas paredes. As propriedades físicas dos blocos cumpriram com os requisitos das normas estabelecidas, o que valida sua utilização. Os resultados do ensaio à compressão mostraram que as pequenas paredes reforçadas com a fibra obtiveram valores muito próximos ou mesmo superiores aos obtidos para as pequenas paredes sem fibras, apresentando melhor desempenho que os blocos e prismas. Todos os elementos reforçados mostraram um ganho da capacidade de deformação e ductilidade conferida pelo sisal, observado nas curvas tensão vs deformação. O modo de ruptura dos blocos, prismas e pequenas paredes de referência foi caracterizado por uma fratura brusca e catastrófica e os reforçados mantiveram suas partes unidas pela fibra vegetal, não perdendo sua continuidade e tornando a ruptura um processo progressivo.

Por outro lado, a principal desvantagem das fibras de sisal é a degradação da celulose, seu principal constituinte, na presença do meio alcalino, provocando a redução da resistência mecânica e da tenacidade dos compósitos. Tal fragilização pode ser associada principalmente 
com a mineralização das fibras devido à migração de produtos de hidratação, especialmente de hidróxido de cálcio, para os vazios da fibra. Sobre esse aspecto de deterioração, muitas pesquisas tiveram como objetivo estudar e melhorar a durabilidade da fibra vegetal em ambiente agressivo.

Toledo et al. (2000) desenvolveram um programa experimental para avaliar a durabilidade do sisal exposto à soluções alcalinas de cálcio e hidróxido de sódio na argamassa. Os corpos de prova reforçados foram expostos ao ar livre e aos ciclos controlados de molhagem e secagem. O desempenho de durabilidade dos compósitos foi avaliado utilizando os resultados dos ensaios de flexão. Com base nos resultados pode-se concluir que as fibras vegetais de sisal são altamente sensíveis à alcalinidade da matriz de cimento. As fibras imersas em solução de hidróxido de cálcio com um pH de 12 durante 300 dias perderam completamente a sua flexibilidade. Isso pode ser atribuído, principalmente, à cristalização da cal no lúmen, paredes e vazios da fibra. A extensão do ataque alcalino foi menor quando as fibras foram acondicionadas em solução de hidróxido de sódio com pH 11. A fragilização dos compósitos fabricados com fibras curtas de sisal foi maior do que a observada em amostras reforçadas com fibras longas. Isso pode ser atribuído a uma maior área superficial das fibras curtas, que permitiu uma rápida penetração dos produtos de hidratação do cimento.

A partir dessa pesquisa Toledo et al. (2003) estudaram diversos tratamentos para melhorar o desempenho e a durabilidade do sisal como reforço no concreto. Eles incluem alterações na matriz, como a carbonatação da matriz por meio de cura inicial dos compósitos em um ambiente rico em $\mathrm{CO}_{2}$, substituição de uma parte do cimento Portland por sílica de fumo e escória de alto forno, imersão das fibras em sílica de fumos antes da sua incorporação no cimento Portland, e por último, a combinação da imersão das fibras nas sílicas e do cimento substituído por adições. As amostras foram expostas a ciclos de umedecimento e secagem e os resultados de durabilidade foram avaliados por meio de ensaios de flexão e observações da matriz em um microscópico eletrônico de varredura. Com base nos resultados, pôde-se concluir que em longo prazo a fragilização das fibras de sisal incorporadas na argamassa foi marcadamente reduzida com os tratamentos realizados. $\mathrm{O}$ ataque alcalino e o transporte dos produtos de hidratação do cimento para os vazios da fibra, mecanismos fundamentais que produzem a degradação, foram minimizados. Isso foi possível tornando a matriz menos alcalina com um pH baixo e menor formação de hidróxido de cálcio.

Em anos anteriores, Bergström e Gram (1984) tinham usado a técnica de selar os poros da fibra misturando cera e zinco na argamassa fresca e impregnando as fibras com enxofre. 
Os resultados obtidos foram promissores devido à redução da absorção de água e da porosidade, retardando, assim, a fragilização das fibras. Outras alternativas foram estudadas pelos mesmos autores como a utilização de agentes bloqueadores, tais como silicato de sódio, sulfito de sódio, sulfato de magnésio e compostos de ferro e cobre, mas nenhum deles melhoraram a durabilidade da fibra na matriz cimentícia. Impregnação das fibras com acetato de polivilina, óleo de silicone, borracha de látex e asfalto também não conseguiram evitar que o material fosse mineralizado e petrificado no meio alcalino.

A redução da alcalinidade da matriz por meio da utilização de materiais pozolânicos foi objeto de estudo de vários autores, como Bergström e Gram (1984), Berhane (1994) e Lima et al., (2007). O cimento era modificado com adições de sílica ativa, cinzas volantes, escória de alto forno, cinza de casca de arroz, pedra-pomes e diatomita. Foram observadas melhorias da durabilidade das fibras nos compostos produto da presença do meio alcalino menos agressivo.

Em estudos mais atuais, Silva et al. (2010) produziram um compósito reforçado com sisal que apresentou durabilidade e elevadas resistências à compressão e à tração. Foram empregadas fibras longas para a fabricação de telhas delgadas. Esse tipo de elemento pode ser usado em painéis estruturais, telhados, tanques, tubulações, entre outros. Foram produzidos dois tipos de matrizes reforçadas com sisal: na primeira o cimento Portland foi substituído por $30 \%$ de metacaulim (MK) e 20\% de argila de tijolos calcinada e esmagada, e a segunda foi feita com cimento Portland sem adições. Por meio da substituição de $50 \%$ de cimento pelas MK e argila calcinada foi possível desenvolver uma matriz livre de hidróxido de cálcio. $\mathrm{O}$ objetivo foi avaliar a durabilidade do sisal nos dois tipos de argamassas por meio de envelhecimento acelerado usando o teste de imersão em água quente. Os resultados mostraram que os elementos livres de hidróxidos de cálcio tiveram uma resistência à tração duas vezes superior que os compostos com cimento Portland comúm. Por outro lado, os compósitos livres de $\mathrm{CH}$ submetidos a um envelhecimento acelerado apresentaram resistência máxima à flexão 3,8 vezes maior e uma tenacidade 42,4 vezes maior do que o compósito com cimento Portland, mostrando, assim, a durabilidade da fibra nesse tipo de matriz.

Como se pôde observar, as pesquisas que tratam sobre o melhoramento da durabilidade da fibra de sisal apresentam duas vertentes. A primeira consiste em modificar a composição da matriz a fim de reduzir ou eliminar os compostos alcalinos. Para isso são usadas adições pozolânicas para precipitar o hidróxido de cálcio da matriz, como o silicato de cálcio hidratado, ou os tratamentos com uma concentração mais elevada de $\mathrm{CO}_{2}$ para precipitar o hidróxido de cálcio como carbonato de cálcio. Essas modificações é uma forma eficaz para garantir a durabilidade dos concretos, mas a dosagem dos materiais de cimento deve ser 
cuidadosamente analisada a fim de obter um desempenho semelhante ou superior aos compósitos preparados apenas com o cimento Portland comum. A segunda maneira de melhorar a durabilidade dos materiais compósitos é modificar a superfície das fibras com tratamentos químicos ou físicos para aumentar a sua estabilidade na matriz cimentícia. Alguns desses tratamentos implicam a utilização de reagentes químicos e podem ser complexos, tornando os processos industriais mais caros.

\subsection{Concreto reforçado com fibras}

Segundo Santiago e Selvam (2007), os materiais reforçados com fibras são chamados de materiais compósitos que apresentam uma combinação de pelo menos dois materiais, os quais, após a mistura, ainda podem ser perfeitamente identificados.

O compósito é normalmente formado por duas fases: a matriz e o elemento de reforço. As matrizes são compostas de aglomerantes minerais e de agregados que dão origem a concretos, argamassas ou pastas, conforme as necessidades de uso. De forma simplificada, o componente matricial serve como meio de transferência e homogeneização dos esforços suportados pelos componentes de reforço. Por outro lado, as fibras atuam como elementos de reforço com a finalidade de impor obstáculos à propagação de fissuras, além de funcionar como ponte de transferência dos esforços, absorvendo parte das solicitações, garantindo, assim, uma capacidade resistente após a abertura da mesma e tornando a ruptura um processo progressivo (CAETANO et al., 2004).

A interface fibra-matriz permite um trabalho conjunto para que ocorra uma adequada transferência dos esforços entre o reforço e a matriz, devido à aderência entre a matriz e o componente. Por esse motivo, um fator importante para o desempenho do compósito é garantir a qualidade da interface (FERREIRA et al., 2012)

Outras características, como quantidade, volume relativo, comprimento, fator de forma e orientação das fibras também influenciam no desempenho dos materiais compósitos.

Se a quantidade de fibras for maior, o número de microfissuras interceptadas pelas fibras será maior, melhorando assim a resistência e a tenacidade. Consequentemente, melhor será o desempenho do conjunto, retardando a propagação das fissuras e propiciando um aumento na tensão máxima, devido ao aumento de contribuição de resistência mecânica das fibras nas propriedades mecânicas do compósito. Isso ocorre porque o carregamento imposto à matriz é parcialmente transferido às fibras que passam a absorver parte das tensões internas.

Por outro lado, o aumento da quantidade de fibras está intrinsecamente ligado a uma redução da trabalhabilidade da mistura, produto da absorção de água pelas mesmas e ao 
acréscimo da área superficial de molhagem, o que pode causar problemas de homogeneidade. Por essa razão foi introduzido o conceito de volume máximo de fibras, ou seja, a máxima quantidade de fibras que pode ser adequadamente incorporada à matriz de modo a se obter uma dispersão uniforme (SILVA, 2010).

A quantidade de fibras em uma matriz de concreto é comumente indicada por meio de seu porcentual volumétrico em relação ao volume total de concreto ou argamassa, denominado $\mathrm{V}_{\mathrm{f}}(\%)$. Outra maneira é por meio do porcentual em massa de fibras em relação ao volume de concreto, representado por $\mathrm{W}_{\mathrm{f}}(\%)$.

Em relação ao fator de forma (razão entre o comprimento da fibra e o seu diâmetro), quanto maior seu valor, para um determinado comprimento, maior será a quantidade de fibras presente na matriz, garantindo um reforço mais eficiente. A forma da ruptura das fibras vai depender fundamentalmente da dimensão longitudinal. Fibras mais longas são rompidas enquanto que em fibras curtas a ruptura geralmente ocorre por arrancamento, pois o comprimento de ancoragem é insuficiente, ocasionando o escorregamento da fibra do interior da matriz cimentícia (CAETANO et al., 2004).

Este trabalho é uma continuação de uma pesquisa já iniciada no trabalho de mestrado da autora titulado "Uso de fibra natural em blocos de concreto para alvenaria estrutural" (2011) que teve como objetivo avaliar o comprimento e teor em volume das fibras que causaram o melhor desempenho físico e mecânico no concreto. O sisal apresentou resistência à tração de $463 \mathrm{MPa}$, um módulo de elasticidade de 15,9 GPa e os comprimentos avaliados foram de 20 e $40 \mathrm{~mm}$ e os teores de 0,5 e $1 \%$. Os resultaram mostraram que os compósitos com fibras de $20 \mathrm{~mm}$ e $1 \%$ de adição apresentaram o melhor desempenho físico e mecânico tanto para os blocos, prismas quanto para as pequenas paredes. Dessa forma, esse comprimento e essa proporção de fibra com relação ao volume do concreto são os utilizados para estudar a durabilidade do sisal nos blocos. 



\section{ALVENARIA DE BLOCOS DE CONCRETO}

\subsection{Bloco de concreto}

O bloco de concreto surgiu nos Estados Unidos no ano de 1900. A primeira máquina semi-automática para fabricar essas unidades data de 1904. Os blocos de concreto chegaram ao Brasil na década de 1950, quando se importou dos Estados Unidos uma máquina para produção desses componentes. Em 1966 foi instalada em São Paulo a primeira fábrica de blocos de concreto de alvenaria estrutural, mas foi somente na década de 1970 que esses blocos se consolidaram no mercado brasileiro. Isso ocorreu devido, principalmente, à divulgação das primeiras obras de alvenaria armada em blocos de concreto (BUTTLER, 2007).

Segundo Medeiros e Sabbatini (1993), a maioria das normas define blocos de concreto de maneira incompleta, buscando o conceito dos materiais constituintes ou utilizando as dimensões e geometria dessas unidades. No Boletim Técnico da Escola Politécnica da USP, elaborado por esses autores, bloco de concreto é definido como "a unidade de alvenaria constituída pela mistura homogênea, adequadamente proporcionada, de cimento Portland, agregados miúdo e graúdo, conformada por meio de vibrações e prensagem, possuindo dimensões superiores a 250 x 120 x $55 \mathrm{~mm}$ (comprimento x largura x altura)".

Segundo a classificação dos blocos quanto ao material componente, as unidades mais utilizadas no Brasil para edificações de alvenaria estrutural são: unidades de concreto, unidades cerâmicas e unidades sílico- calcáreas (Tabela 3.1). Quanto à forma, as unidades podem ser maciças (tijolos) ou vazadas (blocos). São consideradas maciças aquelas que possuem um índice de vazios de no máximo $25 \%$ da área total. Se os vazios excederem esse limite, a unidade é classificada como vazada.

Tabela 3.1 - Classificação dos blocos (Fonte: autor).

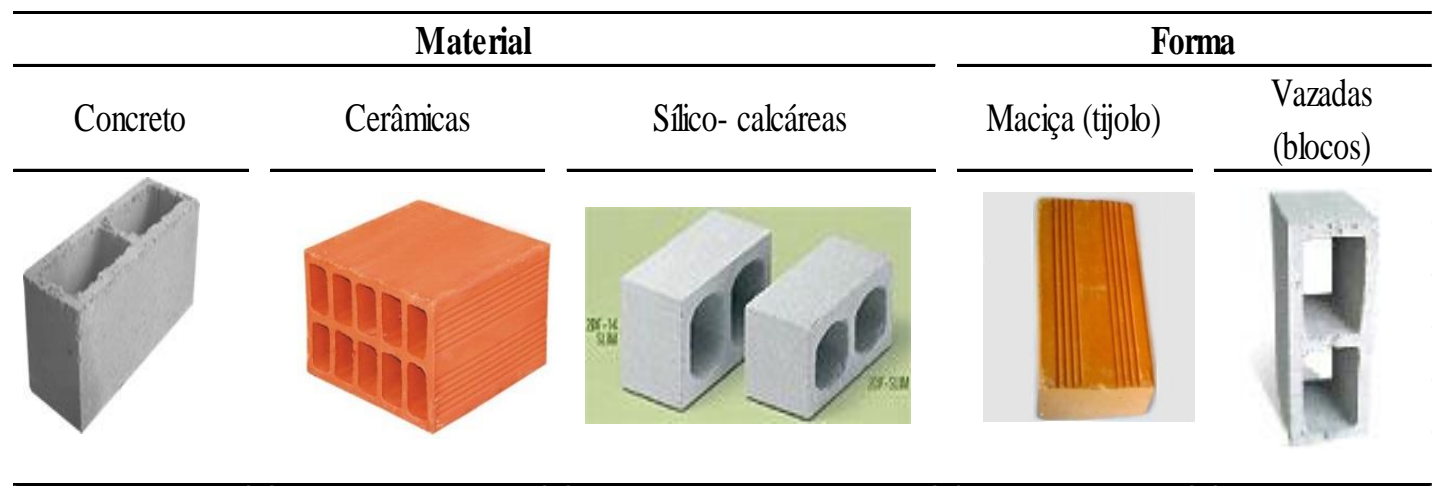


A NBR 6136: 2014 "Blocos vazados de concreto simples para alvenaria - requisitos" classifica os blocos de acordo com a sua função, estrutural ou de vedação. A partir disso, deve-se escolher a dimensão do bloco para que seja usado o maior número de componentes básicos no projeto. Além da dimensão, outras características do produto são consideradas, como a absorção, retração, textura e resistência à compressão. Os blocos destinados à vedação têm resistência média à compressão de, no mínimo, 2,5 MPa. Já os blocos estruturais devem apresentar resistência característica à compressão mínima de 4 MPa para alvenarias revestidas por argamassa e construídas acima do nível do solo, ou 6 MPa para alvenarias não revestidas e enterradas.

Os blocos definem a resistência aos esforços mecânicos, durabilidade à agentes agressivos, estabilidade e precisão dimensional. Dessa forma, constituem os componentes básicos da alvenaria estrutural, sendo os principais responsáveis pela definição das características resistentes dos elementos estruturais (ZHAI; STEWART, 2010).

\subsubsection{Materiais constituintes}

Usualmente, para a fabricação de blocos, são utilizados cimento Portland, agregado miúdo (areia natural/artificial e/ou pó de pedra), agregado graúdo (pedrisco) e aditivo plastificante.

As propriedades dos agregados são fundamentais na produção de blocos de concreto, pois interferem na aderência com a pasta de cimento, na homogeneidade e na resistência e compactação do concreto (HOLANDA, 2000).

A classificação dos agregados com relação à sua forma e dimensão é importante para garantir um bom arranjo no concreto. Desse modo, pode-se obter um material com menor índice de vazios, melhorando assim suas propriedades físicas e mecânicas. Contudo, a distribuição granulométrica dos agregados que compõem os concretos pode ser composta a partir de duas ou mais composições. Assim, procura-se obter um produto com alta densidade a partir do empacotamento das partículas, tal que os espaços entre as partículas maiores são preenchidos pela classe de partículas imediatamente menor e, assim sucessivamente (KINGSLEY, 2003).

Com relação ao cimento, todos os tipos de cimento Portland podem ser utilizados na produção dos blocos de concreto. A utilização do cimento de alta resistência inicial é recomendada, pois acelera a desmoldagem do material.

Holanda (2000) relata que para facilitar a moldagem dos blocos alguns fabricantes utilizam aditivos plastificantes e incorporadores de ar. Isso permite a redução do fator 
água/cimento, o aumento da coesão do concreto, diminuição da exsudação e fácil acabamento. Também facilita a limpeza das partes da máquina que entram em contato com a mistura, proporcionando aumento da produtividade do equipamento. Por outro lado, o uso de aditivos poderia modificar/aumentar as interações entre os pós residuais e a matriz cimentícia, o que não permitira a análise isolada do comportamento dos resíduos no concreto. À vista disso, no desenvolvimento dos concretos não foram utilizados aditivos complementares, para que os resultados obtidos não ficassem vinculados ao uso desses materiais.

A água para uso na fabricação de blocos de concreto deve ser isenta de impurezas e de matéria orgânica, seguindo a mesma recomendação para uso em concreto convencional.

\subsubsection{Processo de fabricação dos blocos de concreto}

Os fabricantes de blocos de concreto utilizam em sua produção processos totalmente mecanizados e automatizados. De atividade tipicamente manual de construção civil, chegouse a um processo industrial que vem se desenvolvendo altamente pelo mundo (FIORITI; AKASAKI, 2007).

O concreto empregado na produção de blocos é de consistência seca, levemente umedecido, devido à menor quantidade de água empregada na mistura. Isso faz com que esses concretos possuam abatimento zero e não é válida a Lei de Abrams, sendo necessário o uso de máquinas especiais que confiram compacidade à mistura quando inserida nas fôrmas.

Chamam-se vibroprensas as máquinas produtoras de artefatos de cimento Portland. Essa denominação advém do tipo de mecanismo empregado para fazer com que o material de dosagem penetre e preencha as fôrmas. O mecanismo de vibração das vibroprensas é um dos principais responsáveis pela qualidade dos componentes que são moldados. Essa vibração governa as operações de moldagem e colabora diretamente para a prensagem dos blocos (FIORITI; AKASAKI, 2007).

A umidade alcançada na produção das unidades deve ser a maior possível (6 a 8\%) para que as unidades não se esboroem. Para os concretos secos, quanto mais água puder ser incorporada à mistura, para uma determinada quantidade de cimento, maior será a resistência e compacidade. Também será maior a plasticidade facilitando a prensagem do material nas fôrmas da máquina, entretanto ressalta-se que se essa quantidade for excessiva poderão ocorrer problemas de desforma e deformações indesejáveis nas peças durante o transporte (TANGO, 1994).

De modo geral, o desempenho do maquinário e do processo produtivo é fundamental para que se alcance a resistência e as características desejadas. A resistência dos blocos é 
proporcional à energia de compactação utilizada na vibração, sendo a eficiência da vibroprensa a responsável direta pela qualidade final das unidades produzidas (BUTTLER, 2007).

Em resumo, o processo de fabricação dos blocos envolve a moldagem de concreto de consistência rija em moldes com as dimensões pré-estabelecidas do bloco, compactados e vibrados por máquinas automáticas, e posteriormente levados para cura e armazenagem até o momento da entrega.

\subsection{Metodologias de dosagem}

Os blocos de concreto devem cumprir os seguintes requisitos: a) coesão no estado fresco; b) máxima compacidade; c) resistência mecânica compatível; d) textura superficial. A composição ideal entre os agregados é um dos primeiros passos para a dosagem dos concretos secos. Esse procedimento baseia-se na formulação de uma mistura com um mínimo de vazios possíveis, visando alcançar as maiores massas unitárias. A busca por um menor volume de vazios permite encontrar uma proporção entre agregados que resulte em uma mistura mais compacta por ter relação direta com a resistência à compressão. Além disso, quanto maior a umidade da mistura, para cada teor de cimento, maiores serão as resistências alcançadas. Entretanto, caso essa quantidade seja excessiva, poderão ocorrer problemas na desforma (FRASSON JÚNIOR, 2000).

A seguir são descritas as principais metodologias de dosagem para concreto seco apresentados na pesquisa de Buttler (2007):

\section{Método da Besser Company}

O método adotado pela Besser Company, fabricante americana de máquinas vibroprensas, baseia-se no ajuste de traço pela granulometria final das misturas, mais especificamente seu módulo de finura. Esse método, que foi muito utilizado pela empresa Encol, inicia-se com uma proporção pré-estabelecida: $40 \%$ de pedrisco e $60 \%$ de areia média, em massa, variando-se essas porcentagens de acordo com a análise granulométrica dos materiais. Caso haja deficiência na granulometria (falta de finos), pode-se usar um terceiro material, como por exemplo, uma areia fina na tentativa de ajustar o módulo de finura final da mistura que deve ficar entre 3,60 e 3,75. A partir da análise das proporções mais adequadas de agregados, deve-se executar a produção de traços-piloto a fim de testar a resistência dos blocos. 


\section{Método da ABCP}

O método sugerido pela Associação Brasileira de Cimento Portland (ABCP) baseia-se na determinação de proporções entre areia e pedrisco que resultem na máxima compacidade da mistura e, consequentemente, na maior resistência. $\mathrm{O}$ método consiste na comparação de massas que cabem em um recipiente padronizado e de volume conhecido. O procedimento é descrito nos itens subsequentes:

- $\quad$ secagem dos agregados - areia e pedrisco;

- os agregados são previamente misturados e colocados em um recipiente com quadro (colarinho) metálico já adaptado $(40 \mathrm{~cm}$ x $40 \mathrm{~cm})$ e de volume conhecido.

Procede-se o adensamento, retira-se o quadro, rasa-se e é efetuada a pesagem. A composição de maior massa será a ideal indicando a máxima compacidade possível;

- caso haja mais de dois agregados, determina-se a composição com os dois mais graúdos e depois a composição desses agregados com o miúdo.

$\mathrm{O}$ método proposto pela $\mathrm{ABCP}$ não leva em consideração a granulometria nem as características particulares do agregado, o que resulta, muitas vezes, no alcance de misturas compactas, mas pouco coesivas. Outra deficiência apontada se refere à não inclusão do cimento nos estudos de composição, uma vez que esse material fino é extremamente importante na redução do volume de vazios e, principalmente, na coesão das misturas. A metodologia também é falha quando se utiliza um terceiro agregado para suprir a necessidade de finos da mistura. Em traços já dosados, quando se utilizou areia fina nas misturas, foram obtidos resultados que conduziam a um consumo excessivo desse agregado para o menor volume de vazios com consequente redução da resistência mecânica dos blocos. Isso está associado a que a alta superfície específica do material demanda quantidades elevadas de água e pasta de cimento (FRASSON JUNIOR, 2000).

\section{Método de dosagem do menor volume de vazios}

O método de dosagem do menor volume de vazios para misturas secas é baseado no ensaio de massa unitária do agregado. O método consiste na comparação de misturas de areia e pedrisco que cabem em um recipiente padronizado de volume conhecido (BUTTLER, 2007). Para se efetuar o ensaio deve-se respeitar o seguinte procedimento:

- secagem prévia dos agregados;

- produção de misturas homogeneizadas contendo quantidades variáveis dos dois componentes $(30 \%, 40 \%, 50 \%, 60 \%, 70 \%$ e $80 \%$ de massa de areia em relação à 
massa total do agregado);

- lançamento das diferentes misturas no recipiente cilíndrico, em três camadas iguais, compactando cada uma com 25 golpes da haste, com a ponta arredondada voltada para baixo. Compactada a última camada e rasado o material excedente, precede-se com a pesagem do recipiente cheio.

Com base nesses dados é traçada uma curva para determinar o ponto ótimo da mistura na qual a proporção de agregado obtém o menor volume de vazios. A determinação do volume de vazios é dada pela equação 1:

$$
V_{\text {vazios }}=\frac{\left[V_{\text {rec }}-\left(\frac{\%_{\text {areia }} \times M}{100 \times d_{\text {areia }}}+\frac{\%_{\text {pedrisco }} \times M}{100 \times d_{\text {pedrisco }}}\right)\right]}{V_{\text {rec }}} \times 100
$$

Na qual:

d: massa específica dos agregados;

M: massa da composição necessária;

Vrec: volume do recipiente;

\%: proporção dos materiais na composição.

A relação entre as massas de agregado e cimento depende, principalmente, do equipamento de moldagem, sendo essa relação baixa quando a energia de adensamento for pequena, indicando alto consumo de cimento. Caso contrário, quando há disponibilidade de um equipamento capaz de fornecer energia de adensamento elevada, a relação entre as massas de agregado e cimento é maior conduzindo a um menor consumo de cimento por unidade. Além disso, as máquinas com graus de compactação elevados são capazes de produzir unidades que cumpram com outros requisitos normativos tais como absorção, textura e retração (FRASSON JÚNIOR, 2000).

\section{Método de dosagem da composição granulométrica}

O método de dosagem da composição granulométrica é baseado na metodologia adotada pelo Departamento Nacional de Estradas de Rodagem. Segundo essa metodologia, a mistura final deve apresentar uma granulometria densa, isto é, com o máximo de empacotamento dos grãos da mistura. Para o cálculo das curvas limites relacionadas à granulometria densa da mistura é utilizada a equação 2 :

$$
P R=100-100 \times\left(\frac{d}{D}\right)^{n}
$$

Na qual:

PR: porcentagem, em massa, que fica retida na peneira de diâmetro 'd'; 
D: diâmetro máximo dos agregados;

d: diâmetro da peneira desejada

n: constante.

A mistura pode ser considerada de granulometria densa quando sua curva granulométrica se enquadrar entre as curvas de " $n=0,35$ " e " $n=0,55$ ". A equação 2 é denominada de Füller quando "n=0,50". Na Figura 3.1 são apresentados os valores limites para que a mistura seja de granulometria densa (SILVEIRA; ROCHA; CHERIAF, 2004).

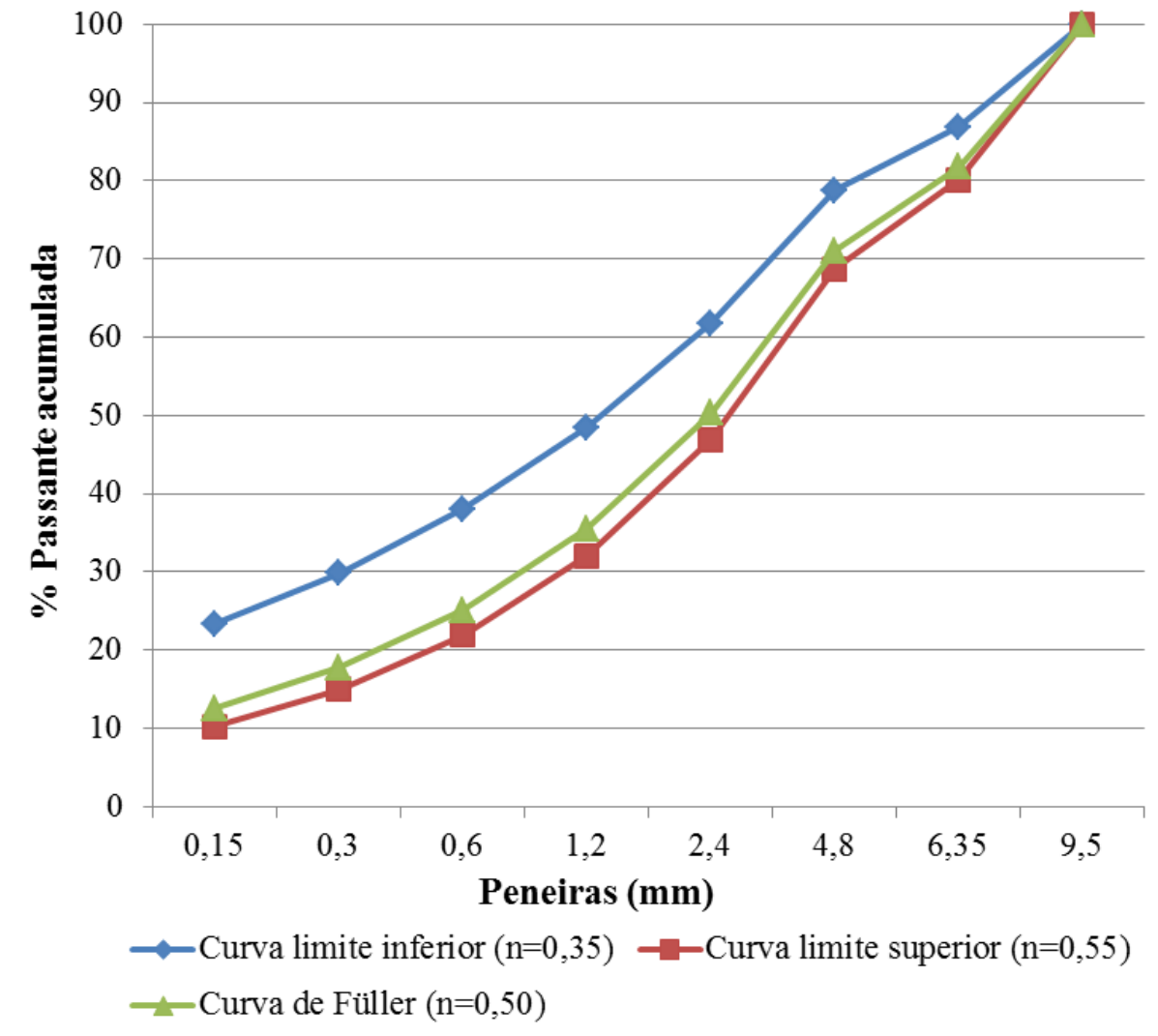

Figura 3.1 - Valores limites para que a mistura seja de granulometria densa (Fonte: autor).

\section{Método de dosagem da Columbia}

O método sugerido pela Columbia, fabricante norte-americana de vibroprensas, recomenda que a porcentagem de agregados graúdos varie entre $25 \%$ e $55 \%$ do total de agregados, com distintas proporções de cimento. Com relação à granulometria, a combinação de agregados graúdos e miúdos deve possuir o total passante na peneira $9,5 \mathrm{~mm}$ de $20 \%$ a $30 \%$ do total retido na peneira 4,8 $\mathrm{mm}$. Além disso, é recomendado que a quantidade mínima de finos seja de $12 \%$ a $15 \%$, em volume, passantes na peneira $0,3 \mathrm{~mm}$, com relação a mistura total (incluindo o cimento). Essa quantidade de finos produzirá misturas com boa trabalhabilidade, facilidade de compactação e coesão; por outro lado, porcentagens menores 
aumentarão a porosidade, absorção, permeabilidade e diminuirão a estabilidade do bloco verde; já percentagens maiores poderão afetar a resistência mecânica dos blocos.

\subsection{Argamassa de assentamento}

A NBR 15961-1: 2011 "Alvenaria estrutural - blocos de concreto, parte 1: Projetos" define argamassa de assentamento como o "elemento utilizado na ligação entre os blocos de concreto, garantindo distribuição uniforme de esforços, composto de cimento, agregado miúdo, água, cal ou outra adição”.

A argamassa deve possuir módulo de elasticidade adequado e reunir boas características de trabalhabilidade, resistência, plasticidade e durabilidade para o desempenho de suas funções. (MIRANDA et al., 2013). A função original da argamassa na alvenaria era apenas de preencher as irregularidades entre os blocos. Posteriormente foi utilizada para ligar os blocos e vedar as juntas contra a penetração de ar e água. Atualmente, além destas funções, a argamassa é responsável pela transmissão de esforços, transformando a alvenaria em uma estrutura monolítica, e também pela acomodação de deformações. Apesar da influência da argamassa na resistência à compressão da alvenaria (considerada como monolítica) ser muito pequena, a contribuição da argamassa na resistência à flexão e cisalhamento no plano e fora do plano de paredes de alvenaria é muito importante. Esta contribuição será maior quanto melhor for a aderência entre a argamassa e o bloco. A aderência da argamassa não depende de sua resistência à compressão, mas sim da sua trabalhabilidade, ou seja, das suas propriedades no estado fresco (MATA, 2006).

\subsubsection{Propriedades}

Segundo Medeiros e Sabbatini (1993), para que a argamassa atenda a todas as funções atribuídas anteriormente, elas devem apresentar certas propriedades tanto no estado fresco como no endurecido:

a) Ter capacidade de retenção de água suficiente para que uma elevada sucção do bloco não prejudique as suas funções primárias;

b) Ter trabalhabilidade (consistência, plasticidade e coesão) suficiente para que o pedreiro produza com rendimento otimizado um trabalho satisfatório, rápido e econômico;

c) Adquirir rapidamente alguma resistência depois de assentada para resistir a esforços que possam atuar durante a construção;

d) Desenvolver resistência adequada para não comprometer a alvenaria da qual faz parte, não devendo ser mais resistente que os blocos que ela une; 
e) Ter suficiente baixo módulo de elasticidade de maneira a acomodar as deformações intrínsecas (retração na secagem e de origem térmica) e as decorrentes de movimentos estruturais de pequena amplitude da parede de alvenaria, sem fissurar;

f) Ter adequada aderência aos blocos a fim de que a interface possa resistir a esforços cisalhantes e de tração e prover a alvenaria de juntas estanques à água de chuva;

g) Ser durável e não afetar a durabilidade de outros materiais ou da construção como um todo.

\subsubsection{Tipos de argamassas}

As argamassas de assentamento de unidades podem ser classificadas em função do aglomerante empregado nos seguintes tipos: argamassa de cal; argamassas de cimento Portland com aditivos e sem aditivos; argamassas com cimentos de alvenaria e argamassas de cimento e cal (mistas) (SOLÓRZANO, 1994).

As argamassas de cimento Portland com aditivos são argamassas que usam aditivos plastificantes, geralmente incorporadores de ar, com objetivo de aumentar a trabalhabilidade e a retenção de água. No Brasil, estas argamassas têm sido muito pouco utilizadas na alvenaria estrutural, pois seu custo é maior em relação à argamassa mista de cal e cimento e de propriedade semelhante. Além disso, dosagens incorretas de aditivos podem trazer consequências adversas.

As argamassas mais adequadas para alvenaria estrutural são as mistas de cal e cimento. Materiais como a cal, incorporados nas argamassas, diminuem a rigidez das mesmas e permitem a acomodação das movimentações intrínsecas à alvenaria. Além disso, a cal favorece a trabalhabilidade, independentemente das modificações nas demais propriedades.

\subsubsection{Dosagem}

Existem critérios para determinação das proporções de materiais e mistura das argamassas. Inicialmente é preciso estabelecer o traço da argamassa para que tenha a resistência e a trabalhabilidade previstas, expressa esta última pela consistência. A elaboração do traço pode ser feito por qualquer método baseado na correlação entre as características de resistência e durabilidade da argamassa e a relação água/cimento. É necessário levar em conta inicialmente a trabalhabilidade e depois fixar a relação água/cimento em função da resistência de dosagem aos 28 dias ou das particularidades da obra, tais como a durabilidade (MATA, 2006). 
Segundo Mohamad (1998), as argamassas podem ser misturadas manualmente ou mecanicamente. $\mathrm{O}$ amassamento manual emprega-se excepcionalmente em pequenos volumes ou em obras de pequeno porte. Para a mistura manual deve-se seguir o seguinte procedimento:

a) $\mathrm{O}$ amassamento deve ser realizado sobre um estrado ou superfície plana impermeável e resistente;

b) Misturar primeiramente a seco os agregados e o cimento de maneira a obter-se cor uniforme;

c) Adicionar aos poucos a água necessária, prosseguindo-se a mistura até a obtenção de uma massa de aspecto uniforme. Não é permitido amassar de cada vez, volume de argamassa superior ao correspondente a $50 \mathrm{~kg}$;

d) Quando for empregada pasta de cal em lugar de cal hidratada em pó, aquela deve ser lançada por último colocando toda água no início da mistura e descontandose a água contida na pasta de cal.

Para o amassamento mecânico deve-se seguir o seguinte procedimento:

a) Colocar parte da água $(70 \%)$ e todo o agregado pondo o misturador em funcionamento;

b) Colocar o cimento com o misturador já em funcionamento;

c) Após algumas voltas do misturador, colocar a cal hidratada e o resto da água.

O tempo de mistura da argamassa deve durar de 3 a 5 minutos.

A NBR 13281: 2005 "Argamassa para assentamento e revestimento de paredes e tetos Requisitos", especifica alguns valores quanto ao desempenho da argamassa, como é mostrado na Tabela 3.2.

Tabela 3.2 - Exigências mínimas das argamassas NBR 13281: 2005 (Fonte: NBR 13281: 2005).

\begin{tabular}{ccc}
\hline Proprie dades & Identificação* $^{\text {Limites }}$ \\
\hline \multirow{2}{*}{ Resistência à compressão aos 28 dias (MPa) } & I & $\geq 0,1 \mathrm{e}<4,0$ \\
& II & $\geq 4,0$ e $\leq 8,0$ \\
Capacidade de retenção de água (\%) & III & $>8$ \\
& Normal & $\geq 80$ e $\leq 90$ \\
Teor de ar incorporado (\%) & Alta & $>90$ \\
& $\mathrm{a}$ & $<8$ \\
* Exemplo de identificação de argamassa: I-Normal-a & \\
\hline
\end{tabular}

A norma americana ASTM C270: 1987 "Standard specification for mortar for unit masonry", especifica o uso das argamassas de assentamento para alvenaria estrutural quanto 
ao traço e quanto às propriedades. Quanto ao traço da argamassa, a norma recomenda que os materiais constituintes devem atender às especificações da ASTM e que a escolha dos traços deve ser feita de acordo com a Tabela 3.3.

Tabela 3.3 - Especificações dos traços das argamassas da ASTM C270: 1987 (Fonte: ASTM C 270: 1987).

\begin{tabular}{cccc}
\hline Tipo de & \multicolumn{3}{c}{ Traço em volume } \\
\cline { 2 - 4 } argamassa & Cimento & Cal & Areia \\
\hline M & 1 & 0,25 & de 2,25 a 3 \\
S & 1 & 0.25 a 0,50 & vezes a soma dos \\
N & 1 & 0,50 a 1,25 & volumes de \\
O & 1 & 1,25 a 2,25 & aglomerantes \\
\hline
\end{tabular}

Quanto às propriedades, a escolha da argamassa de assentamento deve ser feita objetivando-se as propriedades de retenção de água, quantidade de ar incorporado pela mistura e resistência à compressão, sendo que estas propriedades são mostradas na Tabela 3.4.

Tabela 3.4 - Especificações das propriedades das argamassas de cimento e cal da ASTM C270: 1987 (Fonte: ASTM C 270: 1987).

\begin{tabular}{cccc}
\hline $\begin{array}{c}\text { Tipo de } \\
\text { argamassa }\end{array}$ & $\begin{array}{c}\text { Resistência média à } \\
\text { compressão 28 dias (MPa) }\end{array}$ & $\begin{array}{c}\text { Retenção de água } \\
(\%)\end{array}$ & $\begin{array}{c}\text { Ar } \\
\text { incorporado } \\
(\%)\end{array}$ \\
\hline M & 17,2 & 75 & 12 \\
S & 12,4 & 75 & 12 \\
N & 5,2 & 75 & $14^{*}$ \\
O & 2,4 & 75 & $14^{*}$ \\
\hline
\end{tabular}

Somente para argamassas de laboratório

* quando estiver armadura incorporada à junta de argamassa, a quantidade de ar incorporado não deve ser maior que $12 \mid \%$

A norma británica BS 5628 - 1: 1992 "Structural use of unreinforced masonry" especifica a produção e o uso das argamassas de assentamento para alvenaria estrutural. A escolha da classe e do tipo da argamassa a empregar é feita tendo por referência os requisitos estruturais e as caracteríticas dos componentes escolhidos para a execução das alvenarias. A Tabela 3.5 mostra as classes específicas de cada tipo de argamassa e as proporções em volume dos materiais para a execução. 
Tabela 3.5 - Traços das argamassas de assentamento segundo a BS 5628 - 1: 1992 (Fonte: BS $5628-1: 1992)$.

\begin{tabular}{cccccc}
\hline \multirow{2}{*}{$\begin{array}{c}\text { Tipo de } \\
\text { argamassa }\end{array}$} & \multicolumn{2}{c}{ Traço da argamassa (em volume) } & $\begin{array}{c}\text { Resistência média à compressão } \\
\text { aos 28 dias (MPa) }\end{array}$ \\
\cline { 2 - 6 } & $\begin{array}{c}\text { Cimento : Cal : } \begin{array}{c}\text { Cimento de } \\
\text { areia }\end{array} \\
\text { alvenaria : } \\
\text { Areia }\end{array}$ & $\begin{array}{c}\text { Cimento : } \\
\text { areia c/ } \\
\text { plastificante }\end{array}$ & $\begin{array}{c}\text { Ensaios em } \\
\text { laboratório }\end{array}$ & $\begin{array}{c}\text { Ensaios em } \\
\text { obra }\end{array}$ \\
\hline (i) & $1: 0$ a $0,25: 3$ & & & 16,0 & 11,0 \\
(ii) & $1: 0,5: 4$ a 4,25 & $1: 2,5$ a 3,5 & $1: 3$ a 4 & 6,5 & 4,5 \\
(iii) & $1: 1: 5$ a 6 & $1: 4: 5$ a 6 & $1: 5$ a 6 & 3,6 & 2,5 \\
(iv) & $1: 2: 8$ a 9 & $1: 5,5$ a 6,5 & $1: 7$ a 8 & 1,5 & 1,0 \\
\hline
\end{tabular}

\subsubsection{Resistência à compressão}

A resistência à compressão da argamassa não influi de forma significativa na resistência à compressão da parede. De fato, ela é secundária se comparada à resistência de tijolos e blocos por ocupar aproximadamente $20 \%$ do volume total da parede. Além disso, o confinamento das argamassas em ensaios de corpos de prova, sejam cilíndricos ou cúbicos, é significativamente menor que na alvenaria, fazendo com que a resistência dos corpos de prova seja também significativamente diferente da argamassa quando colocada nas juntas de assentamento. De fato, vários autores concordam que a escolha de uma argamassa adequada para uma determinada alvenaria estrutural dependerá do bloco utilizado e de sua resistência à compressão, não podendo ser utilizada de forma isolada como parâmetro representativo no controle da resistência da parede (MOHAMAD et al., 2009).

Embora não seja um parâmetro representativo no controle de resistência da parede, a argamassa deve ter resistência suficiente para distribuir adequadamente as cargas atuantes por toda a área resistente da unidade de alvenaria. Deve-se procurar compatibilizar a resistência à compressão da argamassa com a do bloco. Em geral, utiliza-se uma argamassa com resistência inferior à do bloco na área bruta. Segundo Ramalho e Corrêa (2003) a influência da argamassa pode ser considerada importante se a resistência à compressão for menor que $30 \%$ ou $40 \%$ da resistência do bloco.

\subsubsection{Aderência}

A resistência de aderência pode ser definida como a capacidade que a interface blocoargamassa possui de absorver tensões de cisalhamento e de tração, sem romper-se. Uma união adequada vai depender fundamentalmente das características dos dois componentes individualmente e da sua compatibilidade (MATA, 2006). 
Segundo Medeiros e Sabbatini (1993), a insuficiência de aderência entre bloco e junta de argamassa pode prejudicar praticamente todas as propriedades de uma parede de alvenaria. Entre os muitos parâmetros que afetam a aderência da argamassa na alvenaria, incluem-se: a relação água/cimento, o teor de ar incorporado, as condições de cura e o tipo da argamassa utilizado, além das propriedades do bloco. As propriedades dos blocos mais importantes em relação à aderência são: o índice de absorção inicial (sucção) e as condições superficiais (partículas soltas, textura e capilaridade). Parsekian, Hamid e Drysdale (2012) afirma que a compatibilidade entre a argamassa e o bloco é o fator principal para uma boa aderência e que esta é obtida através de uma boa trabalhabilidade da argamassa, de retenção de água compatível com a absorção inicial do bloco, da rugosidade da superfície do bloco e das condições ambientais (temperatura e umidade) durante o assentamento.

A argamassa apresenta grande influência na aderência bloco-argamassa que reflete na resistência a tração e no cisalhamento da alvenaria, esforços que ocorrem principalmente quando há forças laterais. No caso das ações laterais serem predominantes sobre a ação vertical, a aderência entre o bloco e a argamassa passa a ser uma propriedade determinante na alvenaria (DE OLIVEIRA E CORRÊA, 2011).

\subsection{Avaliação do comportamento mecânico na alvenaria}

A principal característica da alvenaria estrutural é a sua resistência à compressão. Esse é o conceito crucial a ser levado em conta quando se discute a alvenaria como processo construtivo para elaboração de estruturas. A resistência dos blocos é a que exerce maior influência na resistência à compressão da alvenaria, ou seja, quanto mais resistente o bloco, mais resistente será a alvenaria (KINGSLEY, 2003)

A avaliação da resistência à compressão da alvenaria pode ser feita de diferentes maneiras, como a estimativa através da resistência de prismas, de pequenas paredes e de paredes em escala real. Em alguns casos também podem ser utilizadas estimativas por meio dos componentes, como é o caso do procedimento utilizado pela norma britânica BS 5628 - 1: 1992, ou através de modelos teóricos de ruptura que foram desenvolvidos por vários pesquisadores (SOTO; RAMALHO, 2012).

Nesta pesquisa será utilizado o primeiro procedimento, sendo importante a definição de alguns conceitos de prismas e pequenas paredes segundo a NBR 15961 - 1: 2011.

Prismas: são elementos obtidos pela superposição de dois blocos unidos por junta de argamassa e destinados ao ensaio de compressão axial, conforme se apresenta na Figura 3.2a. 
Pequena parede: é um conjunto de unidades de alvenaria ligadas por argamassa que deve ter um comprimento de dois blocos e uma altura de cinco fiadas, conforme mostra a Figura 3.2b.

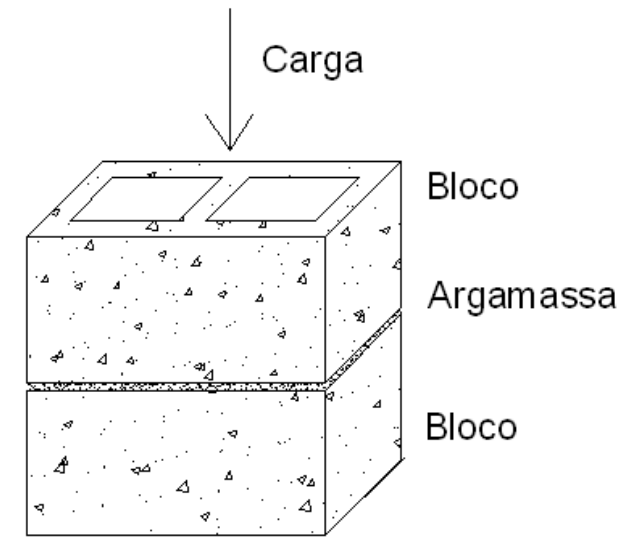

(a)

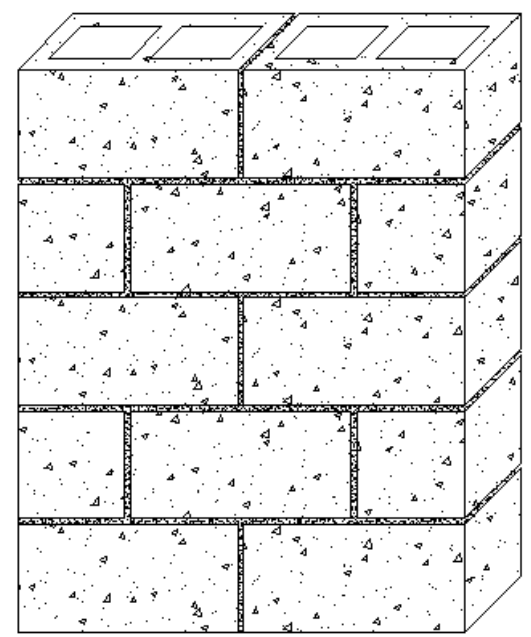

(b)

Figura 3.2 - Elementos de alvenaria de bloco de concreto: (a) prisma e (b) pequena parede (Fonte: Autor).

A estimativa da resistência de paredes por meio do ensaio de prisma é um dos procedimentos adotados pela NBR 15961 - 1: 2011 e apresenta algumas vantagens importantes. É um ensaio mais simples e econômico do que os ensaios de paredes, podendo ser realizado por qualquer laboratório minimamente equipado e é um método de dimensionamento válido para qualquer condição de unidade, argamassa e graute. A eficiência, definida como a relação entre a resistência do prisma e do bloco que o compõe, normalmente varia entre 0,5 a 0,9 para os blocos de concreto. Também existe um valor de eficiência que é definida com a relação entre a resistência da parede e do prisma. Tal valor é muito importante, pois o que interessa em última instância é a resistência da parede. $\mathrm{O}$ valor dessa eficiência situa-se por volta de 0,7 tanto para blocos de concreto como cerâmicos.

As pequenas paredes, apesar de possuírem pequenas dimensões, apresentam resultados de resistência à compressão mais próximos às resistências de paredes do que os prismas. Além disso, representam melhor o modo de ruptura da alvenaria devido à ocorrência de maiores tensões de tração nas unidades provocadas principalmente pelas juntas verticais defasadas. 


\subsection{Mecanismo de ruptura dos elementos}

Em elementos de alvenaria estrutural podem ocorrer esforços de toda ordem, como os esforços de compressão, tração, flexão e cisalhamento. Dessa forma, a função da argamassa de assentamento é a de absorver e transmitir uniformemente esses esforços. Assim, para uma melhor compreensão dos fenômenos de ruptura envolvidos na alvenaria devem ser realizados estudos. Consequentemente, são avaliadas as características mecânicas considerando os materiais num estado de tensões multiaxiais e o consequente ganho de resistência e capacidade de deformação da argamassa.

Vários pesquisadores vêm estudando vários modelos de ruptura. Os dois principais critérios que descrevem a ruptura na alvenaria submetida à compressão são: os critérios de Hilsdorf e de Lenczner.

O critério de Hilsdorf se baseia no comportamento do prisma, que, ao ser submetido a um estado de compressão axial, a parede do bloco tende a se deformar lateralmente devido ao efeito de Poisson. Já a argamassa, por ter um módulo de elasticidade menor, tende a se deformar mais do que o bloco submetendo-o à tensões de tração. Por outro lado, surgem tensões de compressão na argamassa, Figura 3.3 (PASQUALI, 2007).

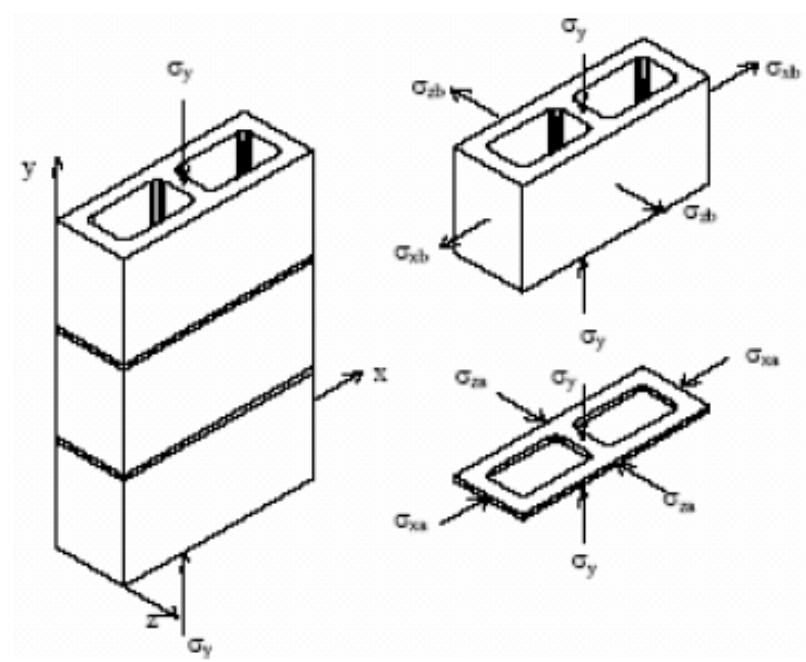

Figura 3.3 - Estado de tensões atuantes nos blocos e nas juntas de argamassa. (Fonte: Da Mata e Ramalho, 2009)

Segundo Pasquali (2007), o critério de Lenczner considera a contribuição da argamassa de assentamento na resistência da alvenaria baseando-se na incompatibilidade de deformações entre os elementos componentes da alvenaria: bloco e argamassa. A argamassa, por possuir um módulo de elasticidade menor que o bloco, fica submetida a esforços de compressão e os 
blocos a esforços de tração. Assim, tende a ocorrer a ruptura no bloco, devido à sua baixa resistência à tração.

Cheema e Klingner (1985) classificam os tipos de ruptura que podem ocorrer na alvenaria, da seguinte maneira:

- Tração no bloco: ocorre onde a tensão de tração principal no bloco supera a resistência à tração do bloco;

- Esmagamento do bloco: ocorre quando a tensão principal de compressão no bloco supera a resistência à compressão do bloco;

- Esmagamento da argamassa: ocorre quando a tensão de compressão axial na argamassa é maior que a resistência da argamassa confinada;

- Fendilhamento da argamassa: é atingida a resistência à tração da argamassa;

- Esmagamento do graute: ocorre quando as tensões de compressão no graute aultrapassam a resistência à compressão confinada do graute.

São de especial interesse a carga e o modo de ruptura do prisma, pois são usados no projeto de alvenaria estrutural. A análise do modo de ruptura serve para, além de validar os resultados experimentais, evitar que alguns modos de ruptura indesejados surjam na parede. Dependendo da propriedade elástica e da resistência dos componentes, o prisma pode romper de forma explosiva, o que deve ser evitado.

Shrive (1982) realizou testes experimentais em prismas de blocos de concreto assentados com argamassa somente nas faces longitudinais. Observou-se que na ruptura dos prismas há o desenvolvimento de tensões de tração na face lateral causadas pela rotação e esmagamento dos apoios. O esmagamento da argamassa lateral induziu a presença de tensões horizontais levando o material à ruptura por flexão. A Figura 3.4 apresenta a ruptura do prisma com o mecanismo gerador de tensões horizontais.
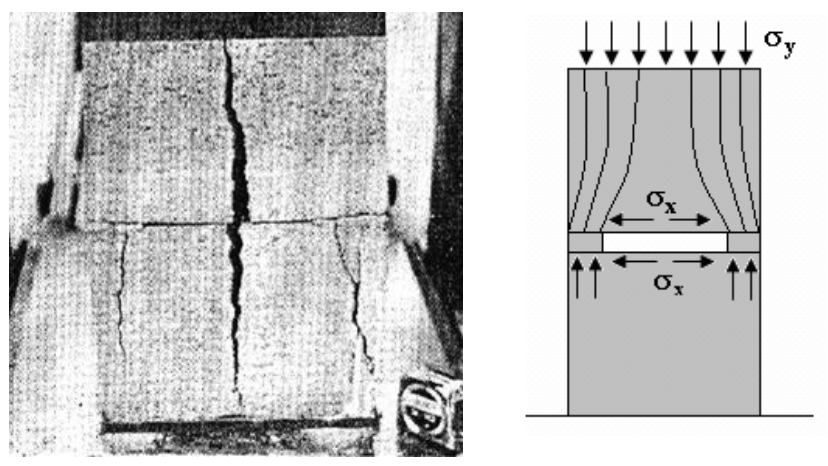

Figura 3.4 - Modo de ruptura e mecanismo gerador de tensões horizontais em prismas de blocos de concreto, com argamassamento nas faces longitudinais (Fonte: Mohamad, 1998) 
Romagna (2000) avaliou o comportamento mecânico de prismas de bloco de concreto submetidos à compressão e com argamassamento total. As fissuras aconteceram, na maioria das vezes, na interseção entre as paredes transversais e longitudinais. As rupturas caracterizadas visualmente demonstraram uma perda da capacidade resistente da argamassa em pontos específicos por onde se propagaram tensões laterais causadas pela sobreposição das unidades. A Figura 3.5 ilustra esse tipo de ruptura nos prismas.

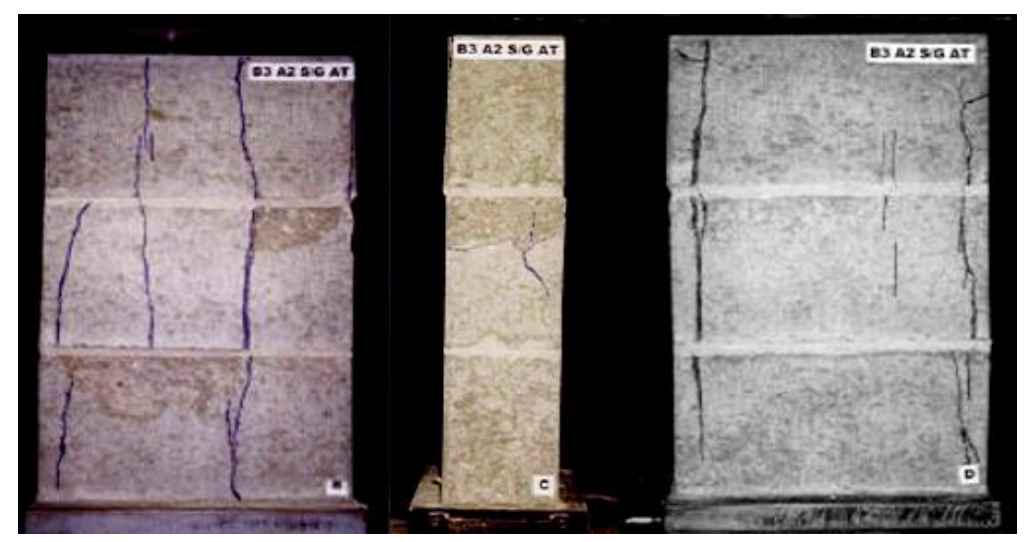

Figura 3.5 - Modo de ruptura de prismas com argamassamento total (Fonte: Romagna, 2000)

Mohamad (1998) realizou estudos experimentais em prismas de blocos de concreto com diferentes traços de argamassa, cujos modos de rupturas são mostrados na Figura 3.6. Nos construídos com argamassa menos resistente (1: 1:6) nota-se o fendilhamento da superfície do bloco em contato com a argamassa, ou seja, aparentemente houve esmagamento localizado da junta de assentamento. O esmagamento da junta não se traduziu na perda da capacidade resistente do conjunto, mas sim no surgimento de fissuras por fendilhamento. Já nos prismas com argamassa mais resistente $(1: 0,5: 4,5)$ foram observadas fissuras na vertical devidas à indução de tensões de tração no bloco que cortavam os septos transversais do bloco e toda a altura do prisma .
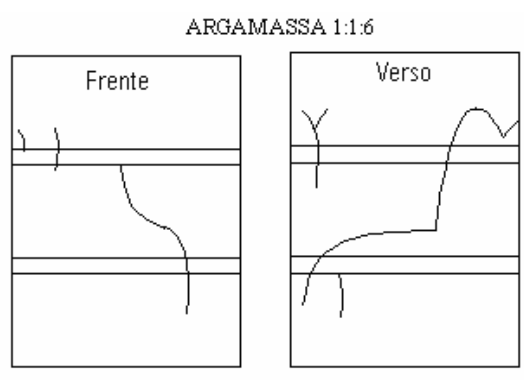

(a)

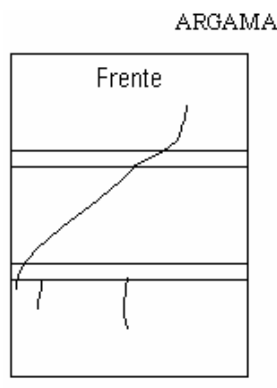

(b)

Figura 3.6 - Modo de ruptura dos prismas concreto com diferentes traços de argamassa: (a) prismas com argamassa 1: 1: 6 e (b) prisma com argamassa 1: 0,5: 4,5 (Fonte: Mohamad, 1998). 
Hamid e Drysdale (1979) sugerem que o mecanismo de indução de ruptura na alvenaria acontece devido ao surgimento de um estado de tensão biaxial tração e compressão, por consequência da pouca rigidez da argamassa de assentamento. O impedimento da deformação lateral da argamassa, pela unidade, faz surgir tensões de confinamento na mesma. Os autores afirmaram que os testes experimentais indicaram que, quando a relação tensão atuante/resistência à compressão dos prismas $(\sigma / f c)$ atingirem um nível de cerca de $80 \%$, acontece o surgimento de micro-fissuras ao longo de toda a extensão dos prismas. Os autores citam que o surgimento de tensões de tração lateral é relativamente pequeno quando comparado com a resistência à tração uniaxial. Pode ser visto na Figura 3.7 que, a região que mostra um significativo aumento nas deformações laterais coincide com o aumento das nãolinearidades do diagrama tensão-deformação à compressão do conjunto. Portanto, pode concluir-se que o surgimento das não-linearidades do diagrama tensão vs deformação vertical corresponde ao aumento das deformações laterais, associando-as à extensiva fissuração do material e a um aumento progressivo do coeficiente de Poisson.
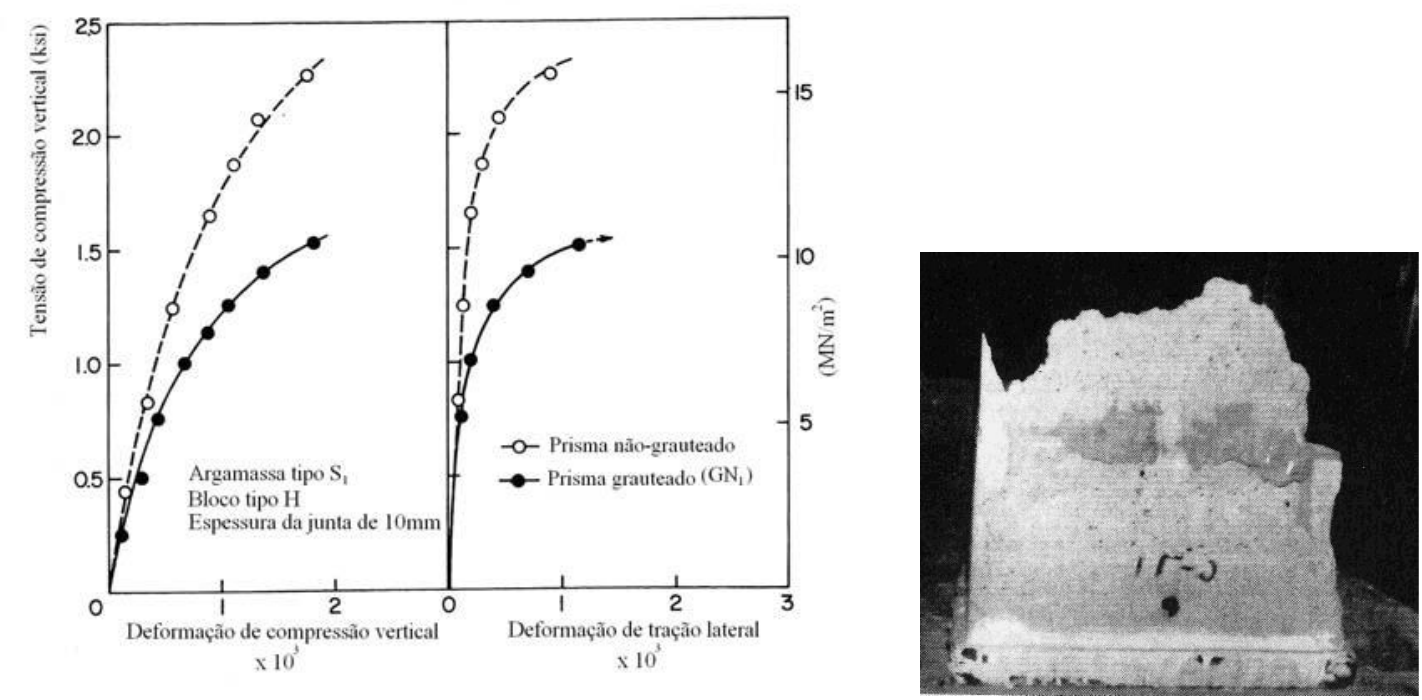

Figura 3.7 - Diagrama tensão-deformação axial e lateral dos prismas com o modo de ruptura do conjunto (Fonte: Hamid e Drysdale, 1979)

Shrive e El-Rahman (1985) afirmam que as causas principais da propagação de microfissuras em concreto e a consequente perda de capacidade resistente devem ser corretamente diagnosticadas através das condições de teste. Os autores asseguram que o concreto possui um comportamento semelhante ao de outros materiais frágeis e, portanto, a trinca desenvolve-se a partir dos vazios internos. A confirmação dessa teoria foi feita pela comparação entre os resultados experimentais e os previstos em ensaios experimentais, sob estados de tensão combinados. A Figura 3.8 permite a visualização das fissuras devidas a um carregamento de 
compressão em prismas com diferentes materiais. Notam-se na Figura 3.8 (a) o esmagamento da argamassa e o esfacelamento das faces do bloco na região indicada com circunferências. Portanto, o início da trinca começa com o esmagamento da junta de argamassa gerando concentrações de tensões no bloco. O tipo de ruptura é, muitas vezes, sem aviso. O fendilhamento apresentado na Figura 3.8 (a) não foi gerado pela indução de tensões de tração, mas sim pelo esmagamento da junta. A Figura 3.8 (b) mostra fissuras generalizadas ao longo de todo o componente, o que pode sugerir modos diferentes de ruptura nos prismas construídos com blocos de concreto.

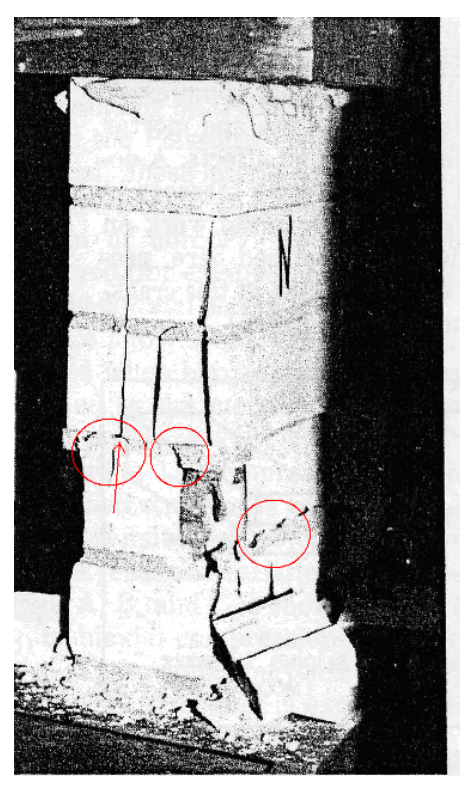

(a)

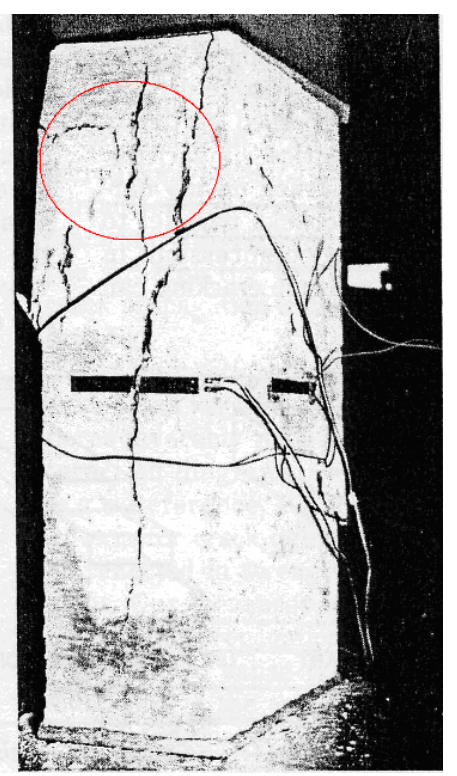

(b)

Figura 3.8 - Ensaio de compressão em prismas com diferentes materiais: (a) em prismas de tijolos cerâmicos e (b) ensaios de compressão em prismas de blocos de concreto (Fonte: Shrive e El-Rahman, 1985)

Hegemeir et al. (1978) forneceram uma explicação para um tipo de ruptura que ocorre nos blocos dos prismas quando as paredes dos blocos rompem por tração despreendendo-se em placas. Conforma pode ser visto na Figura 3.9 (a), tem-se uma junta de argamassa entre as paredes de dois blocos, em corte. Para uma carga de compressão relativamente pequena (30 a $40 \%$ da carga de ruptura) forma-se no centro da junta uma região onde a argamassa está confinada (Figura 3.9, (b)). A argamassa nessa região é mais resistente que a localizada nas regiões externas. Quando a carga aumenta seu valor, essas regiões de menor resistência tendem a romper primeiro, induzindo tração nos blocos, conforme a Figura 3.9 (c). 


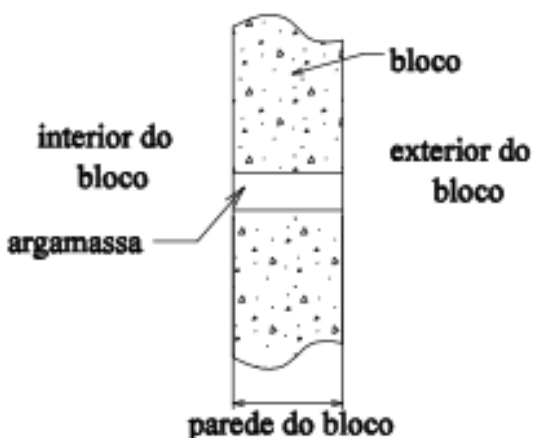

(a)

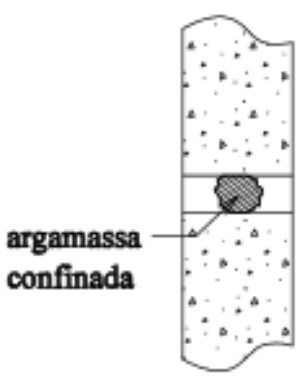

(b)

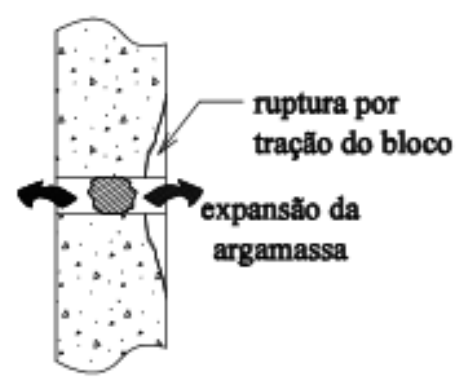

(c)

Figura 3.9 - Ruptura das paredes por tração: (a) junta de argamassa entre os blocos, (b) argamassa confinada na região central da junta e (c) ruptura por tração dos blocos. (Fonte: Hegemeir et al.:1978).

Por conseguinte, para alvenaria de blocos de concreto a ruptura normalmente ocorre devido à ruptura por tração do bloco. Dessa maneira, a função das fibras existentes nos blocos de concreto seria a de permitir as transferências dos esforços de tração, diminuindo a propagação de fissuras, controlando suas aberturas e podendo trazer uma ruptura retardada das unidades de alvenaria.

\subsection{Avaliação do módulo de elasticidade da alvenaria à compressão simples $\left(E_{a l v}\right)$}

Segundo Mohamad (1998), o módulo de elasticidade (E) é a declividade do diagrama tensão vs deformação sob um carregamento uniaxial. É uma propriedade importante na previsão da capacidade de deformação à compressão das alvenarias, blocos, argamassas e graute.

A NBR 8522: 2008 “Concreto - Determinação do módulo estático de elasticidade à compressão" retrata que E pode ser obtido de diferentes maneiras, em função dos pontos selecionados no diagrama tensão $v s$ deformação, conforme mostra a Figura 3.10. O módulo de elasticidade pode, normalmente, ser designado de três formas: módulo de elasticidade tangente $\left(\mathrm{E}_{\mathrm{tg}}\right)$, é a declividade de uma reta tangente ao diagrama em relação a qualquer ponto da mesma; módulo de elasticidade secante $\left(\mathrm{E}_{\mathrm{sec}}\right)$, é a declividade de uma reta traçada de um nível de tensão de $0,5 \mathrm{MPa}$ e uma tensão qualquer correspondente a valores entre $40 \%$ à $80 \%$ da tensão de ruptura $\left(\sigma_{\mathrm{n}}\right)$; módulo de elasticidade tangente inicial $\left(\mathrm{E}_{0}\right)$, é a declividade de uma reta passante pelo nível de tensão de $0,5 \mathrm{MPa}\left(\sigma_{\text {inf }}\right)$ e uma tensão correspondente a $30 \%$ da tensão de ruptura $\left(\sigma_{\text {sup }}\right)$. 


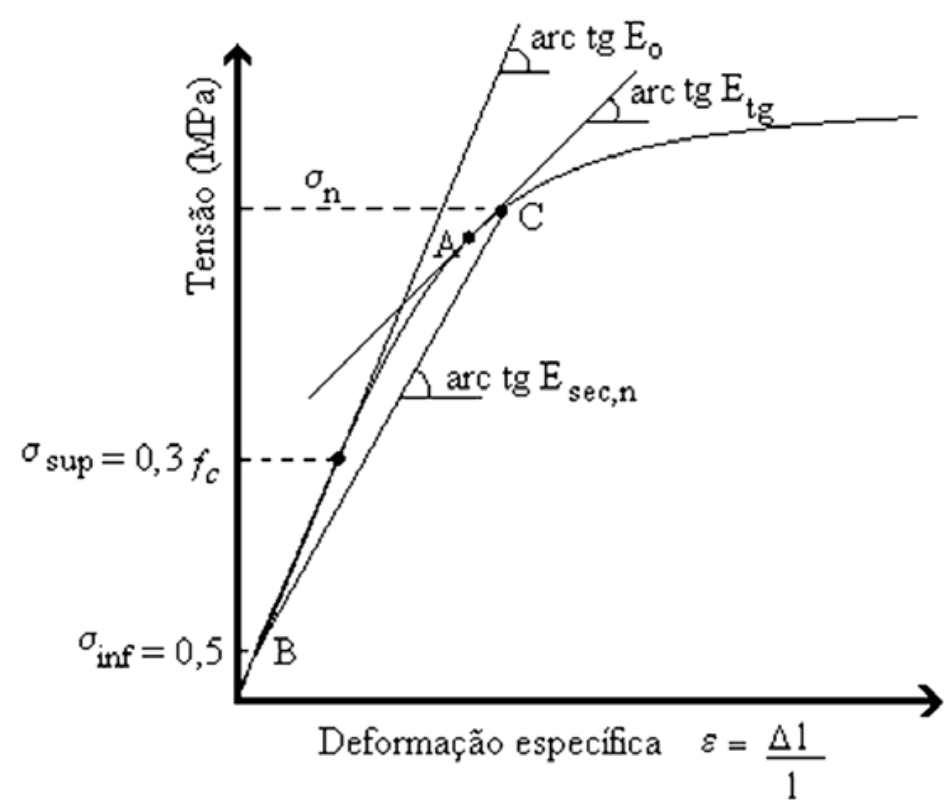

Figura 3.10 - Características dos módulos de elasticidade obtidos a partir do diagrama tensãodeformação (Fonte NBR 8522: 2008).

Knutson (1993) analisou o diagrama de tensões vs deformações da alvenaria para diferentes combinações de argamassa e tijolos (três sólidos e um vazado), como mostra a Figura 3.11. O número indica à resistência do tijolo $\mathrm{e}^{*}$ a argamassa forte. $\mathrm{O}$ autor concluiu que a relação tensão $v s$ deformação pode ser obtida através das equações 3 e 4 , onde $\sigma$ é a tensão normal, $\varepsilon$ é a deformação normal, $\mathrm{f}_{\mathrm{c}}$ é a resistência à compressão da alvenaria e $\mathrm{E}_{0}$ é o módulo de elasticidade tangente inicial. Os estudos desenvolvidos mostraram que os diagramas tensão $v s$ deformação foram diferentes em função do tipo de unidade e argamassa.

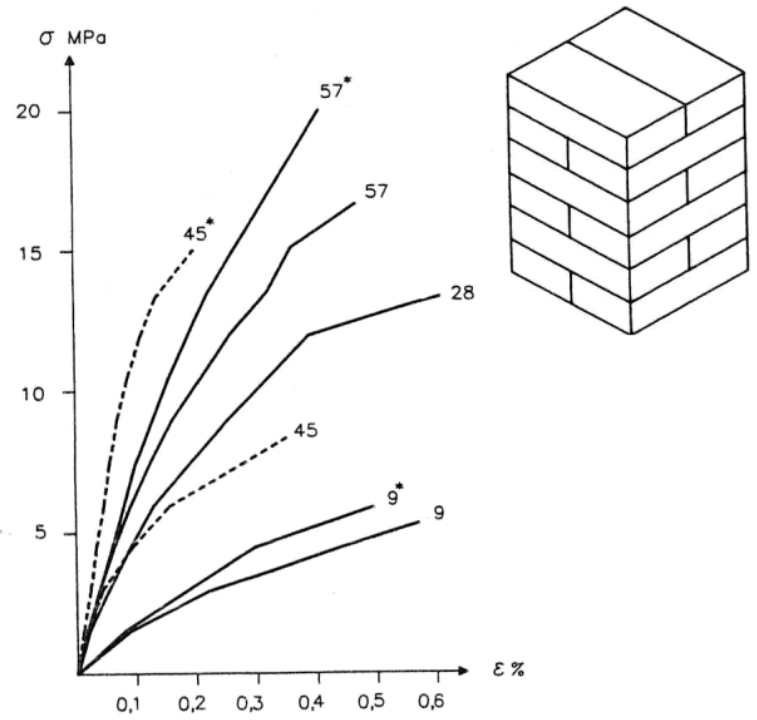

Figura 3.11 - Diagrama tensão-deformação de alvenarias à compressão obtidos usando unidades sólidas e vazadas (linha sólida e tracejada) (Fonte: Knutson, 1993) 


$$
\begin{aligned}
& \varepsilon=-\frac{f_{c}}{E_{0}} \ln \left(1-\frac{\sigma}{f_{c}}\right), \text { se } \sigma / f_{c} \leq 0,75 \\
& \varepsilon=-4 \frac{f_{c}}{E_{0}}\left(0,403-\frac{\sigma}{f_{c}}\right), \text { se } \sigma / f_{c}>0,75
\end{aligned}
$$

Knutson e Nielsen (1995) apresentaram um método padronizado para a obtenção do módulo de elasticidade da alvenaria. As curvas do diagrama tensão $v s$ deformação dos materiais são aproximadas por uma parábola ou por uma curva logarítmica. O método proposto consiste na determinação da inclinação de uma secante entre dois pontos na curva tensão $v s$ deformação. Os corpos de prova são carregados a uma taxa constante de deformação ou alternativamente em aumentos de carga em tempos iguais até $75 \%$ da resistência estimada. Depois disso, o corpo de prova deve ser carregado até a ruptura em um período fixo de tempo $(15 \pm 3)$ minutos. Os resultados do ensaio por esse método pode ser usado para determinar o módulo de elasticidade secante da alvenaria, através da equação 5.

$$
E_{\text {alv }}=\frac{0,35 * f_{c}-0,05 * f_{c}}{\varepsilon_{0,35}-\varepsilon_{0,05}}
$$

Na qual:

$\mathrm{E}_{\mathrm{alv}}=$ inclinação da secante entre os pontos de 0,05 e 0,35 da carga de ruptura;

$\mathrm{f}_{\mathrm{c}}=$ resistência da alvenaria;

$\varepsilon_{0,05}=$ deformação correspondente a uma tensão de 0,05 da tensão de ruptura;

$\varepsilon_{0,35}=$ deformação correspondente a uma tensão de 0,35 da tensão de ruptura.

O módulo de elasticidade da alvenaria com diferentes tipos de unidades e argamassas é um parâmetro bastante variável e por esse motivo, várias equações têm sido sugeridas para a sua determinação. Segundo Colville, Miltenberger e Wolde-Tinsae (1993), alguns pesquisadores chegaram a considerar relações para estimar o módulo de elasticidade a partir da resistência da unidade e do tipo da argamassa. No entanto, tais relações se mostraram muito complexas para uso prático, principalmente porque exigiam uma precisão na estimativa de $\mathrm{E}_{a l v}$ que de fato não existe.

Dhanasekar (1985) relacionou o módulo de elasticidade da alvenaria com a resistência última da mesma $\left(\mathrm{f}_{\mathrm{c}}\right)$. $\mathrm{O}$ autor sugere o uso da fórmula definida pela S.A.A Brickwork Code (Standards Association of Australia) apresentada na equação 6, onde k é uma constante que depende do bloco.

$$
E_{\text {alv }}=k * f_{c}
$$

Tipicamente, as paredes de alvenaria exibem um diagrama tensão vs deformação nãolinear. Muitas das não-linearidades nas deformações da alvenaria de tijolos maciços ocorrem 
na junta de argamassa, pois é usual que o tijolo apresente um comportamento tensãodeformação linear. Dhanasekar (1985) sugere uma relação não-linear para estabelecer o módulo de elasticidade da alvenaria em função da resistência à compressão, apresentada na equação 7 .

$$
E_{\text {alv }}=1180 *\left(f_{c}\right)^{0,83}
$$

Já Henry, Sinha e Davies (2003) definiram o $\mathrm{E}_{\text {alv }}$ pela equação 8, na qual $\sigma_{\mathrm{c}}$ é a resistência ao esmagamento da alvenaria, que é definido em torno de $75 \%$ da resistência última.

$$
E_{\text {alv }}=700 * \sigma^{\prime}
$$

O ACI 530:2011 relata que o projeto de alvenaria de blocos de concreto deve considerar o valor do módulo de elasticidade dado pela equação 9 ou deve ser usado o módulo de elasticidade secante, obtido entre 5\% e 33\% da resistência à compressão máxima do elemento. Este último foi o adotado nesta pesquisa para o cálculo do módulo de elasticidade dos prismas e das pequenas paredes.

$$
E_{\text {alv }}=900 * f_{\text {alv }}
$$

EN 1996-1-1: 2005 fornece uma aproximação simples para determinar o módulo de elasticidade da alvenaria como $k \cdot f_{k}$, onde $f_{k}$ é a resistência à compressão característica da alvenaria, sendo que o valor recomendado para k é 1000.

\subsection{Comportamento do diagrama tensão $v s$ deformação para a alvenaria à compressão}

O comportamento do diagrama tensão vs deformação para as alvenarias à compressão depende de algumas variáveis, tais como resistência à compressão da unidade, a forma da unidade (maciça ou vazada), a resistência à compressão da argamassa, o estado de tensão desenvolvido durante o ciclo de carregamento nos materiais, entre outros (MOHAMAD, 1998).

Mohamad, Lourenço e Roman (2004) analisaram os resultados das curvas tensão vs deformação de prismas confeccionados com duas resistências de blocos (M1 e M2) e quatro traços de argamassas como mostra a Figura 3.12. 


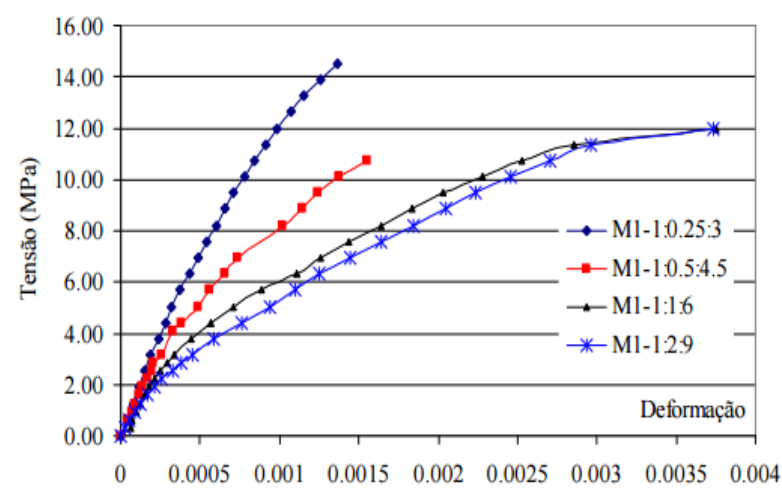

(a)

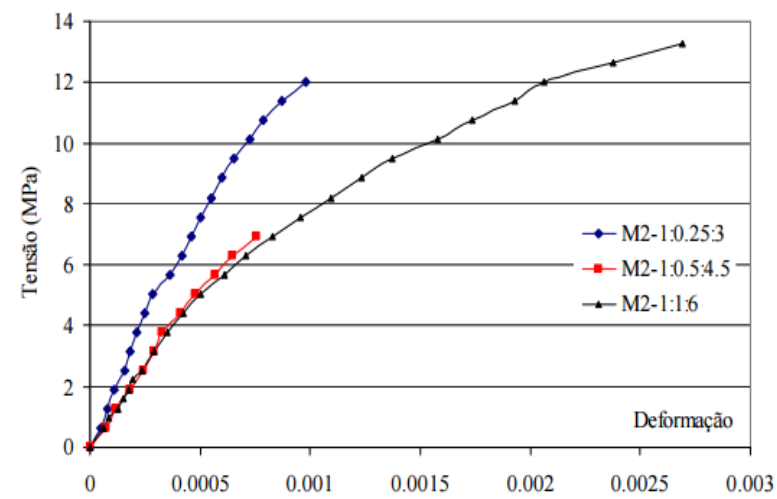

(b)

Figura 3.12 - Diagrama tensão-deformação de prismas de blocos de concreto: (a) Bloco M1 e (b)

Bloco M2. (Fonte: Mohamad, Lourenço e Roman, 2004)

Observa-se que o diagrama tensão $v s$ deformação é dependente da resistência à compressão da junta de assentamento. Quanto menor a resistência à compressão da argamassa, maior é as não linearidades do conjunto. Portanto, os autores concluíram que a não-linearidades da curva tensão $v s$ deformação do conjunto dependem da argamassa utilizada.

Já Romagna (2000) estudou a curva tensão vs deformação de prismas com distinto tipo de assentamento e blocos e argamassas com diferentes resistências à compressão. A Figura 3.13 (a), para prisma com assentamento total e argamassa menos resistente A1 (1:1:6), mostra que há uma lenta deformação até a ruptura total dos prismas. Essa deformação foi tanto maior quanto mais resistente o bloco. Comportamento inverso apresentaram os prismas com argamassa mais resistente A2 (1:0,5:4,5). Nesses observa-se um comportamento linear da curva tensão $v s$ deformação até ocorrer ruptura brusca, Figura 3.13 (b).

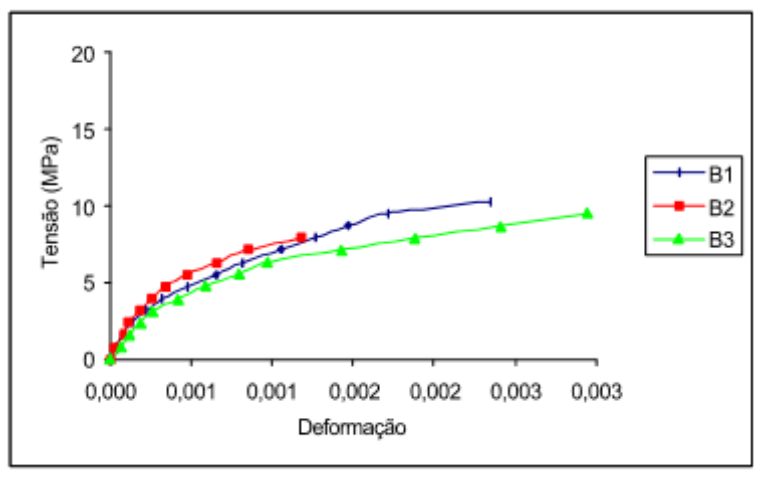

(a)

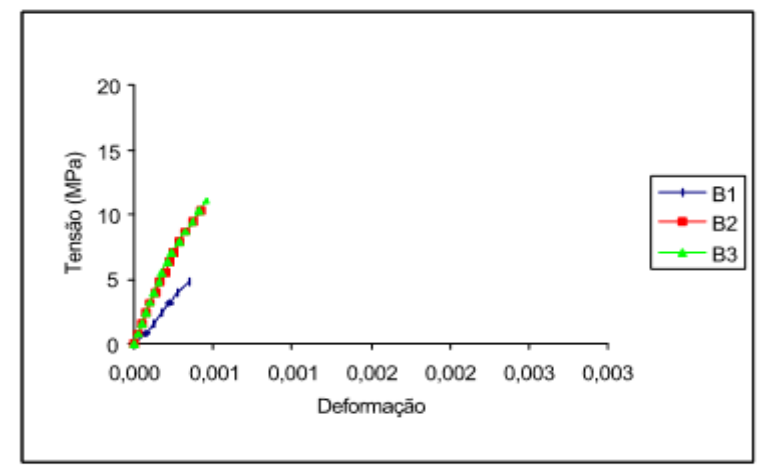

(b)

Figura 3.13 - Diagrama tensão vs deformação de prismas com assentamento total: (a) argamassa A1 (1:1:6) e (b) argamassa A2 (1:0,5:4,5) (Fonte: Romagna, 2000)

Para os prismas com assentamento apenas nas laterais, o comportamento é ligeiramente diferente. Observa-se uma maior ductilidade nos prismas com argamassa mais resistente A2, 
Figura 3.14 (b), quando comparado com o assentamento total, embora ainda neste caso, as deformações antes da ruptura sejam menores do que as obtidas com argamassa A1, Figura 3.14 (a).

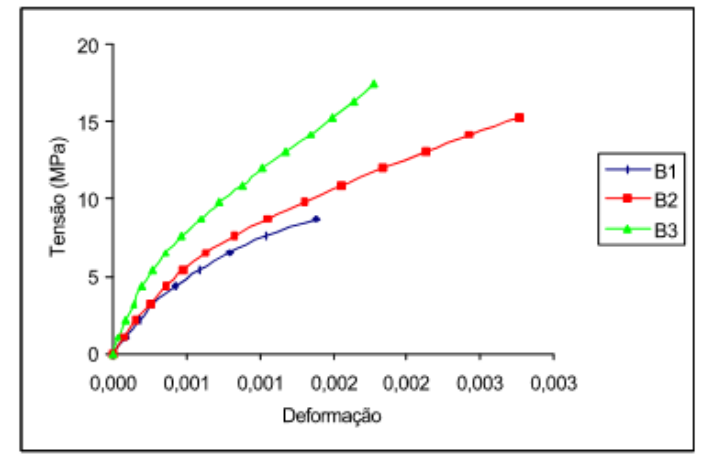

(a)

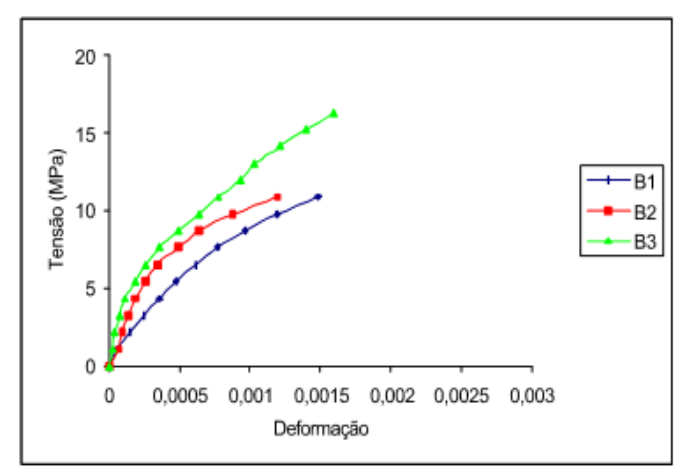

(b)

Figura 3.14 - Diagrama tensão vs deformação de prismas prisma não grauteados com assentamento lateral: (a) argamassa A1 (1:1:6) e (b) argamassa A2 (1:0,5:4,5) (Fonte: Romagna, 2000)

Logullo (2006) realizou ensaios em prismas e paredes vazias, prismas e paredes grauteadas com as diferentes combinações de classes de bloco e graute e com a combinação de blocos, grautes e taxas de armadura. As curvas tensão vs deformação mostraram que os prismas grauteados apresentaram diminuição na deformação de ruptura com a utilização de grautes mais rígidos, e, o grauteamento homogeneizou o comportamento de deformabilidade da alvenaria e do bloco que a constitui, no prisma e na parede. Constatou-se, também, que as armaduras não alteraram o comportamento estrutural dos prismas e paredes, nem na sua resistência à compressão axial e nem na sua deformabilidade.

Izquierdo e Corrêa (2014) estudaram prismas de blocos de concreto grauteados que foram comparados com prismas ocos. Nos prismas grauteados evidenciou-se uma ruptura por desprendimento das faces dos prismas devido á expansão do graute ao ser solicitado axialmente. Segundo a Figura 3.15 (b), as curvas tensão vs deformação mudam de sentido com o incremento das solicitações, correspondendo às tensões de tração que surgem nos corpos de prova. Já os prismas ocos mantiveram o mesmo padrão de ruptura, em que se percebe esmagamento dos blocos, com fissuras verticais bem acentuadas ao longo das suas espessuras, além de serem essas fissuras as primeiras a aparecerem. 


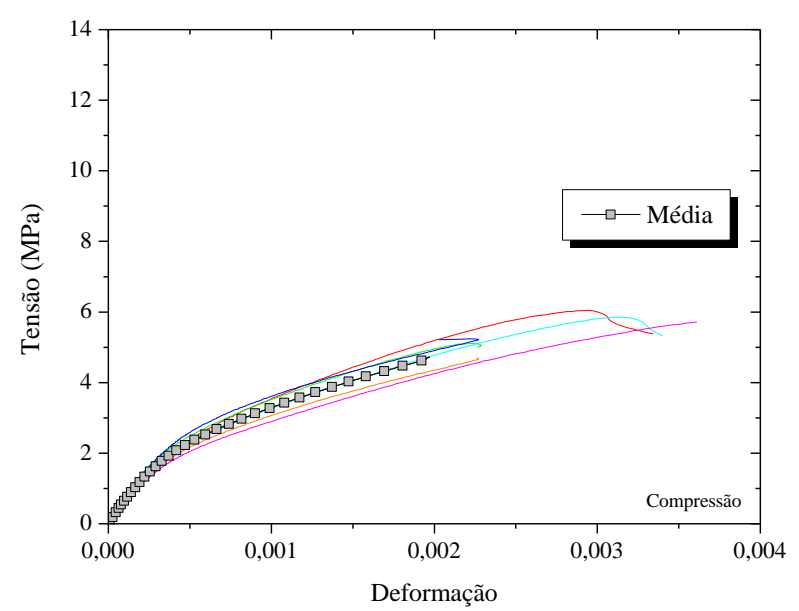

(a)

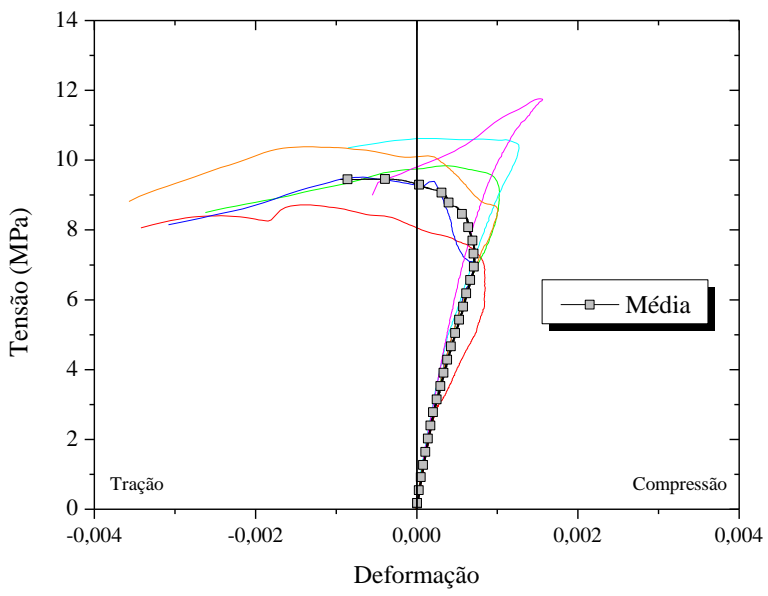

(b)

Figura 3.15 - Curva tensão vs deformação dos prismas de concreto: (a) prisma oco e (b) prisma grauteado (Fonte: Izquierdo e Corrêa, 2014) 


\section{DESENVOLVIMENTO EXPERIMENTAL}

Neste capítulo são descritos os materiais e os métodos empregados para o desenvolvimento do programa experimental da pesquisa. Para atingir os objetivos propostos, a metodologia empregada foi dividida em doze etapas:

$1^{\text {a }}$. Etapa: Descrição do processo para a obtenção dos pós residuais e da fibra de sisal;

$2^{\mathrm{a}}$. Etapa Caracterização química e física do pó residual orgânico, do pó de pedra e da fibra de sisal;

$3^{\text {a }}$. Etapa: Caracterização dos materiais empregados no concreto para fabricação dos blocos;

4 . Etapa: Escolha do método de dosagem e traço para a fabricação do concreto;

$5^{\mathrm{a}}$. Etapa: Produção de corpos de prova cilíndricos $(5 \mathrm{~cm}$ x $10 \mathrm{~cm})$;

6 . Etapa: Caracterização do concreto no estado fresco e endurecido;

$7^{\text {a }}$. Etapa: Avaliação da resistência à compressão do concreto, por meio da técnica do Bootstrap;

8 . Etapa: Escolha da porcentagem ideal de pós residuais que causou o melhor comportamento mecânico e físico no concreto;

$9^{\text {a }}$. Etapa: Produção dos blocos estruturais;

$10^{\mathrm{a}}$. Etapa: Avaliação e caracterização dos blocos

11 ${ }^{\text {a }}$ Etapa: Fabricação dos prismas e das pequenas paredes e análise do desempenho mecânico

12 . Etapa: Avaliação da durabilidade das fibras no concreto.

São apresentados também os equipamentos e procedimentos utilizados durante os ensaios executados no Laboratório de Estruturas.

\subsection{Processo para a obtenção dos pós residuais e da fibra de sisal}

Neste item são descritos os processos para a obtenção do pó de resíduo orgânico, pó de pedra e fibra de sisal utilizados na pesquisa.

\subsubsection{Sistema de tratamento e beneficiamento do resíduo orgânico}

A empresa Gold Press Máquinas e Reciclagem Ltda., localizada em Barretos, São Paulo, desenvolveu um tratamento de resíduos orgânicos, constituindo uma técnica inovadora no país. Essa solução transforma o resíduo em um produto comercial, que pode ser utilizado na 
construção civil. A empresa foi criada em 1979 e desde o início trabalha com reciclagem e fabricação de máquinas, como prensas, moinhos, secadores, sistemas de trituração e lavagem.

O processo que origina o pó residual por meio de reações químicas encontra-se patenteado e certificado pela UNESP de Botucatu, que assegura a qualidade e veracidade do tratamento, podendo ser utilizado em qualquer cidade do Brasil (JERONIMO, 2013). O tratamento é constituído por várias etapas até obter-se o produto final, as quais são explicadas a seguir.

Inicialmente, todo o resíduo urbano que é recebido pelo caminhão é colocado em uma esteira de seleção com rolete magnético para a extração do material metálico. Através da seleção manual são retirados todos os materiais inorgânicos, como madeira, vidro, plástico, borracha, baterias etc., até sobrarem basicamente os resíduos orgânicos (Figura 4.1). Os inorgânicos seguem a linha da reciclagem e os orgânicos seguem a linha destinada ao tratamento.

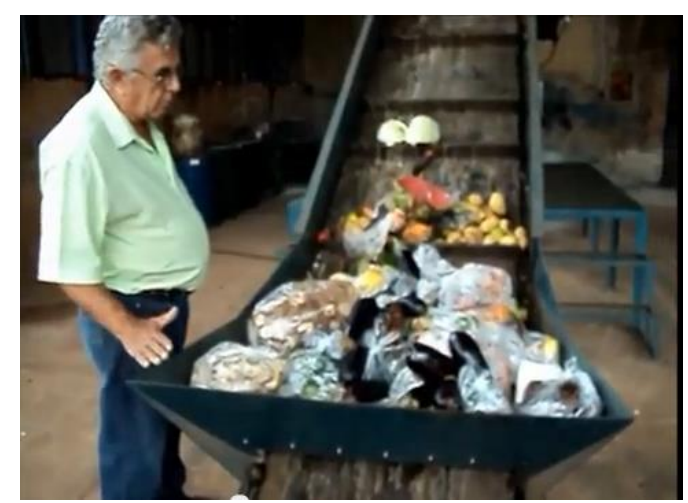

(a)

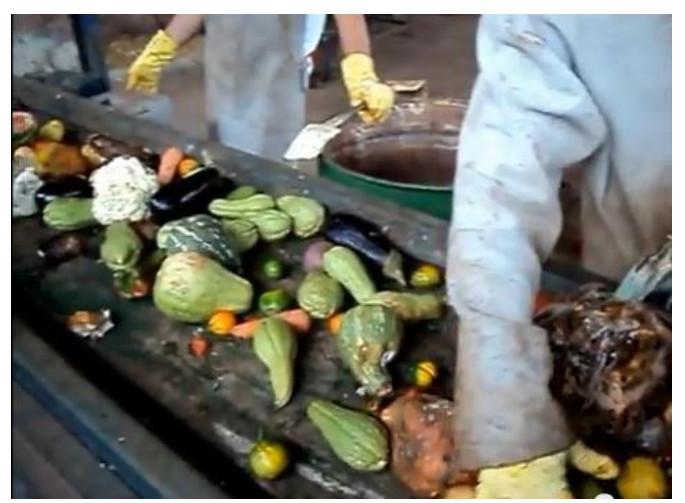

(b)

Figura 4.1 - Etapa inicial: (a) resíduo urbano colocado na esteira de seleção e (b) seleção manual deixando os materiais orgânicos (Fonte: Gold Press Máquinas e Reciclagem)

Ao final da esteira, os resíduos orgânicos passam por um moinho triturador para reduzir a granulometria. Na sequência, são conduzidos para uma câmara onde recebem a adição de produtos químicos para a decomposição do material (Figura 4.2). 


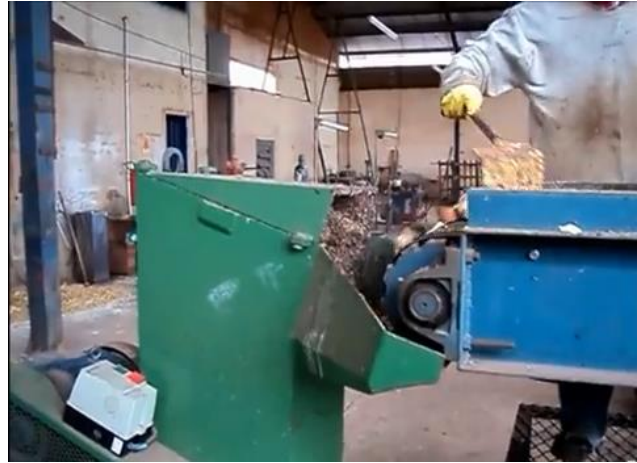

(a)

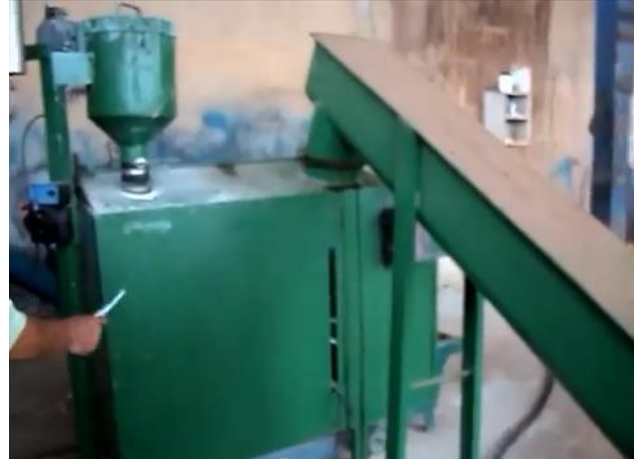

(b)

Figura 4.2 - Etapa intermediária: (a) trituração do resíduo orgânico e (b) transporte até a câmara de reação química (Fonte: Gold Press Máquinas e Reciclagem)

Os produtos químicos, aplicados de forma adequada às características regionais, possibilitam a estabilização de resíduos graxos, chorume, dejetos animais, dejetos humanos e ainda realizam o encapsulamento químico dos metais pesados. O produto final do processo, que dura 40 minutos, é uma massa livre de contaminação química, patogênica e biológica. Essa massa é retirada do reator e secada para depois passar por um processo de micronização e ser transformada em pó (Figura 4.3). A micronização consiste em um processo de moagem ultrafina de produtos por meio de moinhos com ar comprimido. A moagem acontece devido ao choque entre as partículas do próprio produto que, recebendo a energia do ar comprimido, ganha velocidades de até $500 \mathrm{~m} / \mathrm{seg}$. Com o choque, as partículas vão diminuindo de dimensão até atingir a qualidade desejada.

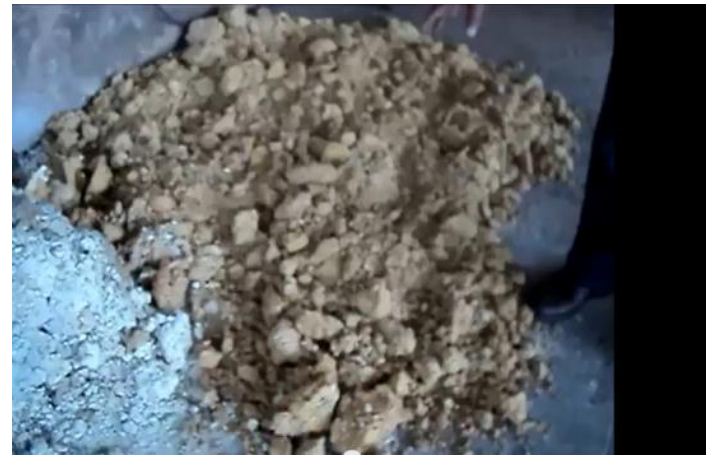

(a)

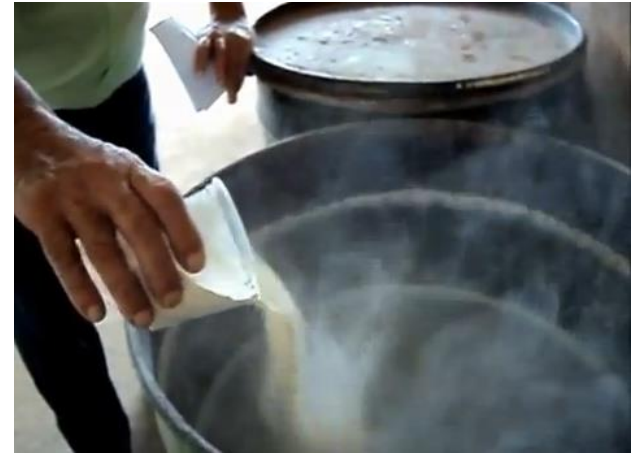

(b)

Figura 4.3 - Etapa final: (a) massa retirada do reator e (b) produto transformado em pó (Fonte: Gold Press Máquinas e Reciclagem)

\subsubsection{Obtenção do pó de pedra por meio do processo de produção da brita}

Segundo Guimaraes et al. (2007), o processo de produção de pedra britada consiste na transformação do maciço rochoso em um produto final acabado. Para tanto, deve-se obedecer diferentes operações unitárias de um processo sequencial. $\mathrm{O}$ desmonte e a britagem da rocha compreendem os seguintes processos: 
1) Decapagem do terreno - Nesse processo é efetuada a limpeza das bancadas, com máquinas e caminhões a fim de remover a argila e outros materiais impróprios para a britagem;

2) Perfuração e colocação de explosivos - Através de uma perfuratriz pneumática sobre esteiras perfura-se a rocha, deixando-a pronta para a colocação de explosivos. Na continuação são colocados os explosivos na quantidade previamente calculada e posteriormente é feita a detonação;

3) Transporte da mina para a britagem - $\mathrm{O}$ carregamento do material detonado é feito com escavadeira hidráulica em caminhões basculantes que transportam o material da mina até britagem primária;

4) Britagem primária - $\mathrm{O}$ material proveniente da mina é descarregado na baia de alimentação e lançado para dentro do britador de mandíbulas, onde é triturado;

5) Britagem secundária - Esse processo tem como função receber o material proveniente da britagem primária, o qual é lançado dentro do britador e triturado de acordo com a abertura do britador, reduzindo ainda mais suas dimensões;

6) Britagem terciária - $\mathrm{O}$ material gerado no processo anterior é conduzido ao britador de impacto vertical (VSI). Nesse processo, o material é arremessado dentro de um compartimento circular fechado, onde ocorrem diversas colisões entre as partículas de pedra e também com as paredes revestidas do VSI, propiciando com isso uma correção no formato dos grãos do agregado, tornando-os arredondados;

7) Peneiramento e classificação - $\mathrm{O}$ material proveniente da britagem é submetido a processos de peneiramento em peneiras vibratórias inclinadas. A seguir são realizados os ensaios de granulometria para sua classificação.

Os produtos finais são brita 4 e $5(50$ a $100 \mathrm{~mm})$, brita 3 (22 a $62 \mathrm{~mm})$, brita 2 (22 a $32 \mathrm{~mm})$, brita $1(12,5$ a $22 \mathrm{~mm})$ e brita $0(5$ a $12 \mathrm{~mm})$. O britador cônico constitui o equipamento mais empregado nas usinas de britagem de pedreiras para dar um formato mais cúbico às britas, podendo ser aplicado a rochas de qualquer dureza (Figura 4.4). 


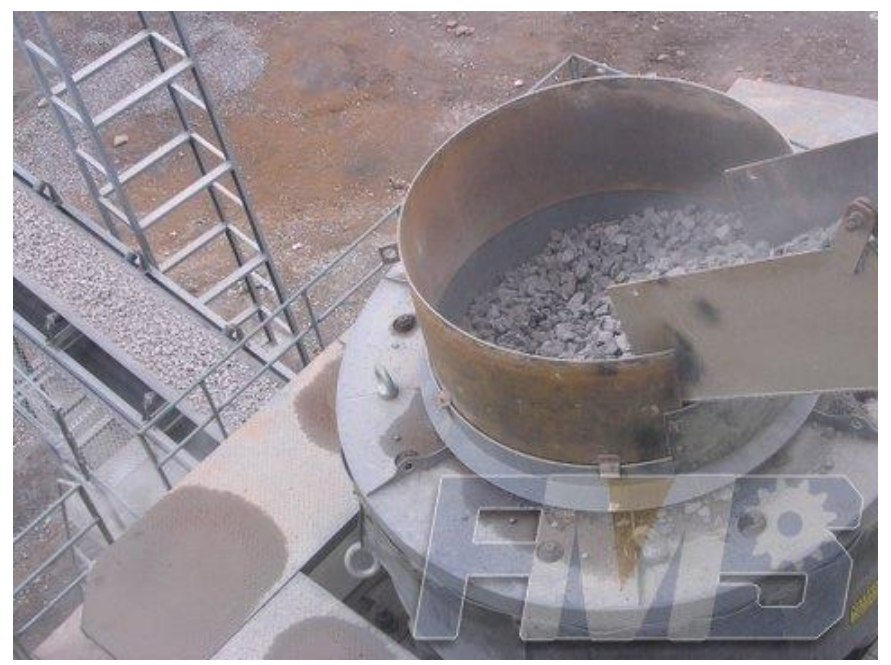

Figura 4.4 - Britador cônico (Fonte: http://www.google.com.br)

Como resultado das diversas britagens e triturações a que é submetida a rocha para a obtenção da brita obtém-se o pó de pedra (0 a $5 \mathrm{~mm}$ ), resíduo que apresenta uma destinação inadequada.

\subsubsection{Colheita e pós-colheita da fibra de sisal}

No cultivo da Agave sisalana o ciclo varia entre 8 e 10 anos. O primeiro corte é realizado aproximadamente aos 36 meses após o plantio, no qual podem ser colhidas de 50 a 60 folhas por planta. As fibras representam apenas $4 \%$ a $5 \%$ da massa bruta da folha do sisal, cortadas a cada 6 meses durante toda vida útil da planta.

As operações de corte, enfeixamento, transporte e desfibramento devem ser sincronizadas. Dessa maneira, as folhas cortadas são beneficiadas no mesmo dia para evitar o murchamento, que dificulta o desfibramento e causa depreciação da fibra.

O desfibramento do sisal é a principal etapa da pós-colheita. Consiste no processo de eliminação da polpa ou mucilagem que envolve a fibra da folha mediante raspagem mecânica. No Nordeste brasileiro, o desfibramento é realizado por meio de uma máquina denominada "Máquina Paraibana" (Figura 4.5). Essa máquina, que envolve um número elevado de pessoas em sua operacionalização, desfibra em torno de 150 a $200 \mathrm{~kg}$ de fibra seca em um turno de 10 horas de trabalho (SILVA; BELTRÃO, 1999). 


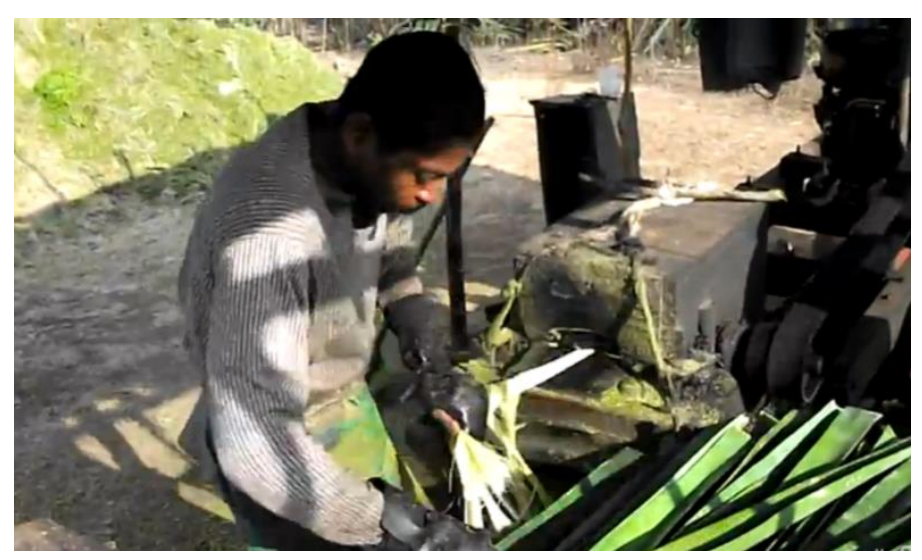

Figura 4.5 - Desfibramento do sisal (Fonte: http://www.veengle.com/s/desfibradora/3.html)

Após o término da operação diária de desfibramento, a fibra obtida é transportada para tanques com água limpa, onde deve ficar imersa durante 8 a 12 horas. Isso é necessário para a eliminação dos resíduos da mucilagem péctica e da seiva clorofílica, que ficam aderidas à fibra de sisal.

A próxima etapa é o batimento, que consiste em remover o pó que envolve a fibra de sisal. Essa etapa se processa em máquinas denominadas batedeiras, localizadas dentro de um galpão fechado. Após o batimento, a fibra é classificada e enfardada para ser comercializada.

A cadeia de serviços de atividades sisaleira abrange desde os trabalhos de extração até as atividades de industrialização para fins artesanais. A indústria do sisal traz diversos benefícios aos municípios localizados no semiárido nordestino nos aspectos econômicos, sociais e ambientais. Dessa forma, com um novo valor agregado às fibras na construção civil existe a possibilidade de abertura de um novo mercado, que pode impactar na economia local, gerando divisas, emprego e renda, servindo de cobertura do solo e impedindo a desertificação.

\subsection{Caracterização química e física dos pós residuais e da fibra de sisal}

A seguir será feita uma descrição dos ensaios de caracterização dos materiais não convencionais utilizados na pesquisa para a fabricação de blocos estruturais em substituição ao cimento e à areia.

\subsubsection{Pó residual de resíduo orgânico}

A Tabela 4.1 apresenta um resumo dos ensaios e metodologia empregados para caracterização do pó de resíduo orgânico. 
Tabela 4.1 - Ensaios e metodologia empregados para caracterização do pó de resíduo orgânico (Fonte: autor)

\begin{tabular}{ccc}
\hline Material & Ensaios & Metodologia \\
\hline & Análise da forma e tamanho & Microscopia eletrônica de varredura \\
& Análise química & $\begin{array}{c}\text { Espectroscopia de energia dispersiva } \\
\text { por raios-X (EDS) }\end{array}$ \\
Pó residual & Análise dos metais pesados & Espectrometria de emissão atômica \\
orgânico & Massa específica & NBR NM 23: 2001 \\
& Módulo de finura & NBR 11579: 2013 \\
& Granulometria & NBR NM 248: 2003 \\
& Superfície específica & NBR 16372: 2015 \\
& Massa unitária & NBR NM 45:2006 \\
\hline
\end{tabular}

\subsubsection{Microscopia eletrônica de varredura (MEV)}

A técnica de microscopia de varredura é rotineiramente utilizada para gerar imagens de alta resolução das formas dos objetos e para mostrar variações espaciais na composição química. Além disso, possibilita identificar fases por meio de análises químicas qualitativas.

No processo de interação do feixe eletrônico com a matéria, os sinais de maior interesse para formação das imagens são os elétrons secundários e os retroespalhados. Os elétrons secundários fornecem imagem de topografia de superfície da amostra e são responsáveis pelas imagens de alta resolução, enquanto que os elétrons retroespalhados fornecem imagens características de variação de composição (BOZZOLA; RUSSELL, 1992).

A técnica tornou-se mais poderosa com o acoplamento de detectores de energia dispersiva de raios-X, possibilitando a realização de análises químicas durante a observação, como é o caso da atual pesquisa, realizando assim a espectroscopia de energia dispersiva por raio-X (EDS).

As imagens foram feitas no Laboratório da Central de Análises Químicas e Instrumentais do Instituto de Química de São Carlos da Universidade de São Paulo. As três amostras analisadas passaram por moagem durante 3 minutos, na rotação 65 RPM, em moinho tipo almofariz-pistilo da marca Marconi, apenas para homogeneização.

\subsubsection{Espectroscopia de energia dispersiva por raio-X (EDS)}

A espectroscopia de energia dispersiva por raio-X (energy dispersive $\mathrm{X}$-ray detector, EDS) é uma técnica essencial no estudo de caracterização microscópica dos materiais. Por EDS podem ser caracterizados elementos com número atômico superior a 11. Quando o feixe de elétrons incide sobre o mineral, os elétrons mais externos dos átomos e os íons constituintes são excitados, mudando de níveis energéticos. Ao retornarem para sua posição 
inicial liberam a energia adquirida, a qual é emitida em comprimento de onda no espectro de raios-X. Como os elétrons de um determinado átomo possuem energias distintas, é possível, no ponto de incidência do feixe, determinar quais os elementos químicos que estão presentes naquele local e assim identificar em instantes que mineral está sendo observado (BOZZOLA; RUSSELL, 1992).

A técnica EDS foi realizada na análise de três amostras de pó de resíduo orgânico no Laboratório de Central de Análises Químicas e Instrumentais do Instituto de Química de São Carlos da Universidade de São Paulo. O equipamento utilizado foi um Microscópio Eletrônico ZEISS LEO 440 (Cambridge, England). O mesmo possui acoplado um sistema de microanálises EDS LINK (Isis System Series 200), com detector de SiLi Link Pentafet, janela ultrafina ATW II (Atmosphere Thin Window), de resolução de $133 \mathrm{eV}$ à 5,9keV. As análises quantitativas por EDS foram calibradas a partir de padrões de cobalto de pureza 99,995\% analisadas a cada hora, de forma a eliminar ou minimizar os efeitos de flutuação na intensidade do feixe. As curvas para todos os elementos analisados foram adquiridas de padrões certificados, em condições idênticas às das análises.

Pode-se resumir que o uso em conjunto do EDS com e MEV é de grande importância na caracterização de materiais. Enquanto o MEV proporciona nítidas imagens, o EDS permite sua imediata identificação. Além da identificação mineral, o equipamento ainda permite o mapeamento da distribuição de elementos químicos por minerais, gerando mapas composicionais de elementos desejados.

\subsubsection{Análise dos metais pesados}

A presença de metais pesados no pó de resíduo orgânico, em teores acima dos recomendados, pode ser um risco de contaminação à saúde e ao meio ambiente. Chumbo, cádmio, níquel, manganês, cobalto, cromo e cobre são alguns dos metais pesados, os quais são altamente reativos e não podem ser destruídos.

Além disso, com relação às interações com a matriz cimentícia, a presença de metais pesados pode afetar o desenvolvimento das resistências e da hidratação dos produtos cimentícios como é apresentado na Tabela 4.2 (CHANDRA, 1997). 
Tabela 4.2 - Influência dos metais pesados na reatividade hidráulica e na qualidade do cimento e concreto (Fonte: Chandra, 1996).

\begin{tabular}{|c|c|c|c|c|}
\hline \multirow[b]{2}{*}{ Metal } & \multirow{2}{*}{\multicolumn{2}{|c|}{$\begin{array}{c}\text { Influência na reatividade } \\
\text { hidráulica }\end{array}$}} & \multicolumn{2}{|c|}{ Influência na qualidade do cimento e } \\
\hline & & & $\begin{array}{c}\begin{array}{c}\text { Início e fim de } \\
\text { pega }\end{array} \\
\end{array}$ & $\begin{array}{c}\text { Desenvolvimento } \\
\text { das resistências }\end{array}$ \\
\hline Cádmio & Não afet: & & retarda & não afeta \\
\hline Chumbo & $\downarrow \mathrm{C}_{2} \mathrm{~S}$ & $\uparrow \mathrm{C}_{3} \mathrm{~A}$ & retarda & diminui \\
\hline Cloretos & $\uparrow \mathrm{C}_{3} \mathrm{~S}$ & $\uparrow \mathrm{C}_{3} \mathrm{~A}$ & acelera & aumenta \\
\hline Cromo & \multicolumn{2}{|c|}{$\downarrow \mathrm{C}_{2} \mathrm{~S}$} & acelera & diminui \\
\hline Manganês & $\uparrow \mathrm{C}_{3} \mathrm{~S}$ & ${ }_{\mathrm{F}} \mathrm{C}_{3} \mathrm{~A}$ & depende do teor & diminui \\
\hline
\end{tabular}

A determinação dos constituintes inorgânicos foi realizada pela técnica analítica de espectrometria de emissão atômica com plasma acoplado indutivamente (ICP - OES). Tal técnica se baseia na emissão de radiação eletromagnética das regiões visíveis e ultravioletas do espectro eletromagnético por átomos neutros ou átomos ionizados excitados. Constitui uma poderosa ferramenta analítica para a determinação de metais e simi-metais em diversos tipos de amostras.

A técnica ICP - OES foi realizada na análise de três amostras de pó de resíduo orgânico no Laboratório Global Análise e Consultoria na cidade de São Carlos.

\subsubsection{Massas específica e unitária e análise granulométrica}

O ensaio de massa unitária das amostras de pó de resíduo foi executado segundo os procedimentos da NBR NM 45: 2006 “Agregados - Determinação da massa unitária e do volume de vazios". A única alteração deu-se em relação ao recipiente, que nesta pesquisa foi alterado para 3 litros, diferentemente do que a norma exige. Essa mudança foi necessária devido à característica dos resíduos, já que não se trata de um agregado e sim de um material pulverulento.

O ensaio de massa específica das amostras foi realizado seguindo as recomendações da norma NBR NM 23: 2001 "Cimento Portland e outros materiais em pó - Determinação da massa específica", utilizando como líquido o querosene e $50 \mathrm{~g}$ de material seco.

A composição granulométrica foi determinada segundo a NBR NM 248: 2003 “Agregados - Determinação da composição granulométrica". As amostras de pó foram peneiradas por 10 minutos no peneirador automático de agregados miúdos, com a seguinte série de peneiras de malha quadrada: 4,8 mm (\#4), 2,4 mm (\#8), 1,2 mm (\#16), 0,6 mm (\#30), 
0,3 mm (\#50), 0,150 mm (\#100), 0,075 mm (\#200) e 0,044 mm (\#375). As porções retidas nas peneiras foram medidas e, a seguir, calculadas as porcentagens retidas acumuladas.

\subsubsection{Pó de pedra}

O pó de pedra utilizado foi rejeito do processo de extração de brita basáltica.

A determinação das massas específicas real e aparente foram feitas conforme a NBR NM 52: 2009 "Agregado miúdo - Determinação de massa específica e massa específica aparente" e a massa unitária, obtida segundo o procedimento da NBR NM 45: 2006. A composição granulométrica do agregado foi determinada de acordo com a NBR NM 248: 2003.

A determinação do teor de material pulverulento do pó de pedra foi feita seguindo os procedimentos da NBR NM 46: 2003 “Agregados - Determinação do material fino que passa através da peneira $75 \mu \mathrm{m}$ por lavagem”, que fixa os valores máximos de material passante na peneira $0,075 \mathrm{~mm}$.

Os equipamentos utilizados nesses ensaios foram agitador mecânico de peneiras da marca Produtest com controle de vibração e temporizador, balança da marca Metter Toledo, modelo SB4001 Delta Range com precisão de 0,1 g e capacidade de 24000 g, estufa da marca Quimes com termostato de $50{ }^{\circ} \mathrm{C}$ a $300{ }^{\circ} \mathrm{C}$, escovas com cerdas de náilon e peneiras da série normal e intermediária. Para o ensaio de massas unitárias foi preciso uma concha, haste de socamento com extremidade semiesférica e recipiente de três litros.

\subsubsection{Fibra de sisal}

A fibra de sisal utilizada na pesquisa foi fornecida pela empresa Tecelagem de Sisal (Tecsal), localizada no estado de Bahia. Segundo a Norma de Identidade, Qualidade, Apresentação e Embalagem da Fibra Beneficiada de Sisal ou Agave e seus Resíduos de Valor Econômico, existem quatro tipos de fibras de sisal: Tipo superior, Tipo 1, Tipo 2 e Tipo 3. O sisal foi do Tipo 3. Esse tipo de fibra é usado para fazer fios em geral e Bale Twine (fios agrícolas para exportação). Caracterizam-se por serem fibras secas, bem batidas ou escovadas, em bom estado de maturação, com brilho e resistências normais, ásperas, com umidade máxima de 13,5\%, soltas, desembaraçadas e isentas de impurezas, como ilustra a Figura 4.6. 


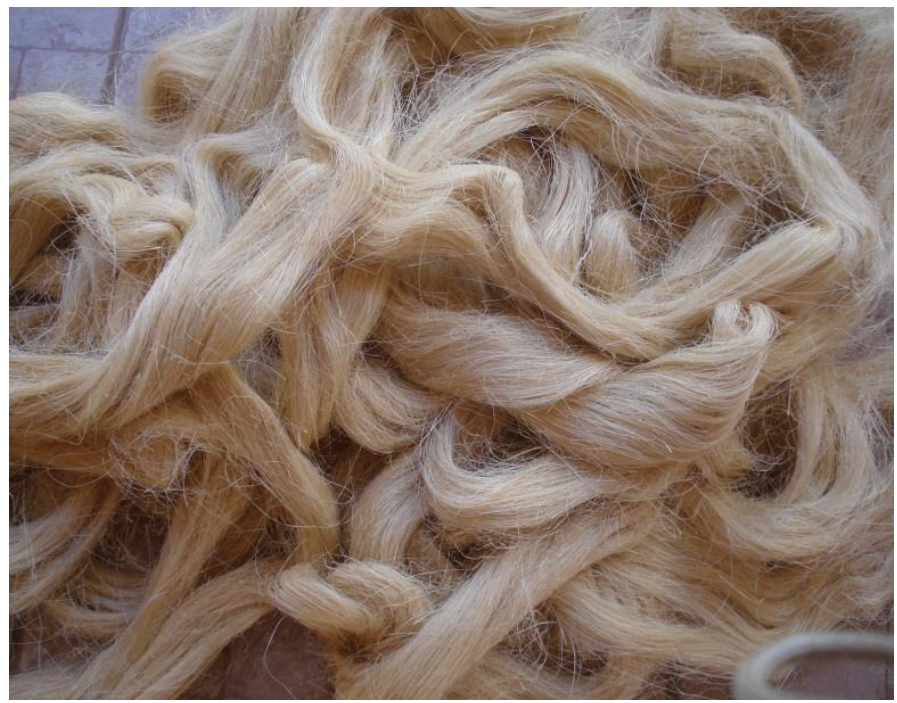

Figura 4.6 - Fibra de sisal Tipo 3 (Fonte: autor)

Logo após o recebimento do material foi determinada a massa específica das fibras, a absorção de água e o teor de umidade para se obter as informações necessárias para a utilização delas como reforço no concreto para blocos.

\subsubsection{Massa específica real e aparente}

As fibras foram cortadas com o auxílio de uma tesoura em comprimento médio de $20 \mathrm{~mm}$, aferido com auxílio de uma régua com precisão de $0,5 \mathrm{~mm}$.

Foi colocada uma quantidade suficiente para o ensaio em um depósito adequado com água durante 24 horas. Após a saturação dos poros permeáveis, a amostra foi disposta sobre uma superfície plana exposta a uma suave corrente de ar. Depois foi pesada em uma balança com sensibilidade de 0,001 g, obtendo-se a massa saturada seca ao ar $\left(\mathrm{M}_{\mathrm{sat}}\right)$. Em seguida colocou-se a amostra em uma proveta graduada com um volume inicial de $600 \mathrm{ml}$ de água (Vi) e fez-se a leitura do volume final $\left(\mathrm{V}_{\mathrm{f}}\right)$, conforme ilustra a Figura 4.7. 


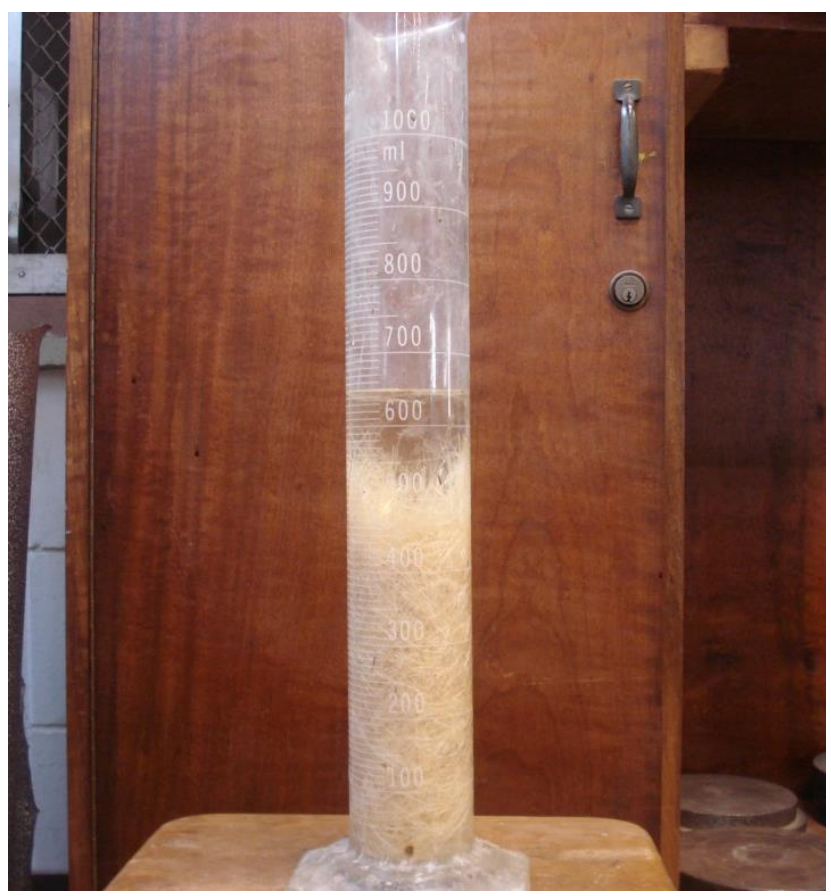

Figura 4.7 - Ensaio da fibra no frasco de $1,000 \mathrm{ml}$ (Fonte: autor)

A amostra saturada, colocada em uma bandeja, foi seca em estufa por 24 horas a uma temperatura de $600{ }^{\circ} \mathrm{C}$. Durante esse período, o material perdeu toda água que se encontrava nos poros permeáveis. Posteriormente, a amostra foi pesada na balança, obtendo-se a massa seca $(\mathrm{Ms})$.

A massa específica real foi calculada por meio da equação 10:

$\rho_{\text {espec real }}=\frac{M s}{\left.(V f-V i)-\left[(M s a t-M s) / \rho_{\text {água }}\right)\right]}$

Na qual:

$\rho_{\text {espec apar: }}$ massa específica aparente da fibra de sisal $\left(\mathrm{g} / \mathrm{cm}^{3}\right)$;

$\mathrm{M}_{\mathrm{s}}$ : massa seca da fibra de sisal após 24 horas na estufa $(\mathrm{g})$;

$\mathrm{M}_{\text {sat }}$ : massa saturada seca ao ar (g);

$\mathrm{V}_{\mathrm{i}}$ : volume inicial do frasco $\left(\mathrm{cm}^{3}\right)$;

$\mathrm{V}_{\mathrm{f}}$ : volume final do frasco $\left(\mathrm{cm}^{3}\right)$.

A massa específica aparente foi calculada por meio da equação 11:

$\rho_{\text {espec apar }}=\frac{M s}{(V f-V i)}$

Na qual:

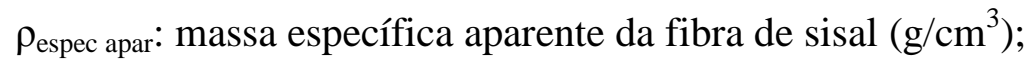

$\mathrm{M}_{\mathrm{s}}$ : massa seca da fibra de sisal após 24 horas na estufa $(\mathrm{g})$;

$\mathrm{V}_{\mathrm{i}}$ : volume inicial do frasco $\left(\mathrm{cm}^{3}\right)$; 
$\mathrm{V}_{\mathrm{f}}$ : volume final do frasco $\left(\mathrm{cm}^{3}\right)$.

\subsubsection{Teor de umidade inicial}

Foi determinado o teor de umidade que a fibra de sisal apresenta quando é exposta ao ar no ambiente de laboratório. As fibras foram secas em estufa a $60{ }^{\circ} \mathrm{C}$ até constância de massa, obtendo-se a massa seca (Ms), como ilustra a Figura 4.8 .

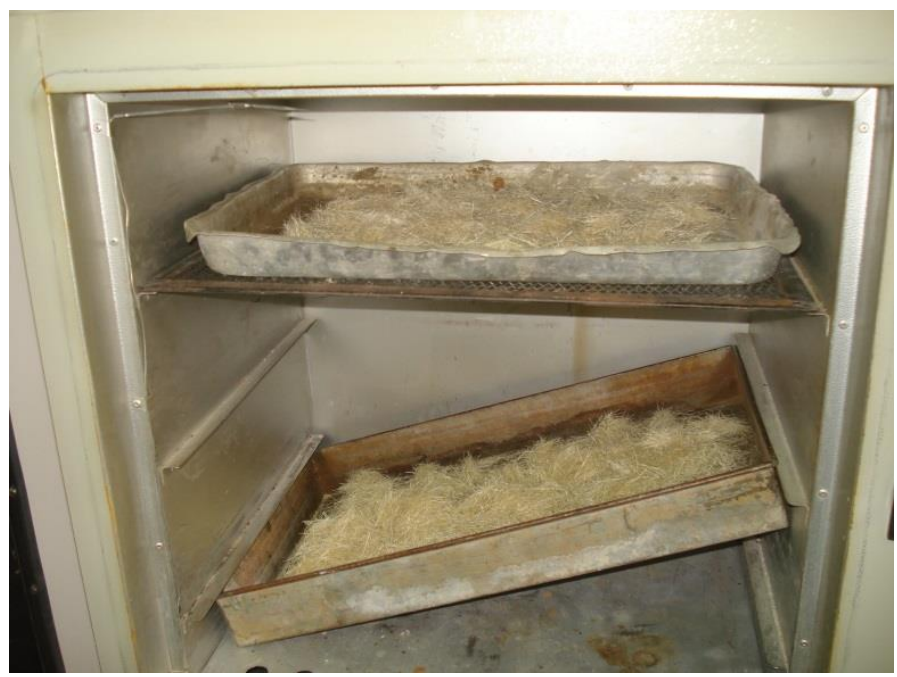

Figura 4.8 - Fibras colocadas na estufa (Fonte: autor)

Em seguida foram retiradas da estufa e expostas ao ar por 24 horas, obtendo-se a massa seca ao ar (Msa).

O teor de umidade das fibras foi calculado conforme a equação 12:

$U=\frac{M s a-M s}{M s} \times 100$

Na qual:

$\mathrm{U}$ : teor de umidade das fibras (\%);

$\mathrm{M}_{\mathrm{sa}}$ : massa das fibras secas ao ar (g);

$\mathrm{M}_{\mathrm{s}}$ : massa seca da fibra de sisal após 24 horas na estufa (g).

\subsubsection{Absorção de água}

Para a determinação da absorção da água, as fibras foram colocadas na estufa a $60{ }^{\circ} \mathrm{C}$ até a constância de massa (Ms). Em seguida foram imersas em água (Figura 4.9) e tiveram sua massa determinada. Para essa determinação foi utilizado papel absorvente para retirar o excesso de água das amostras. 


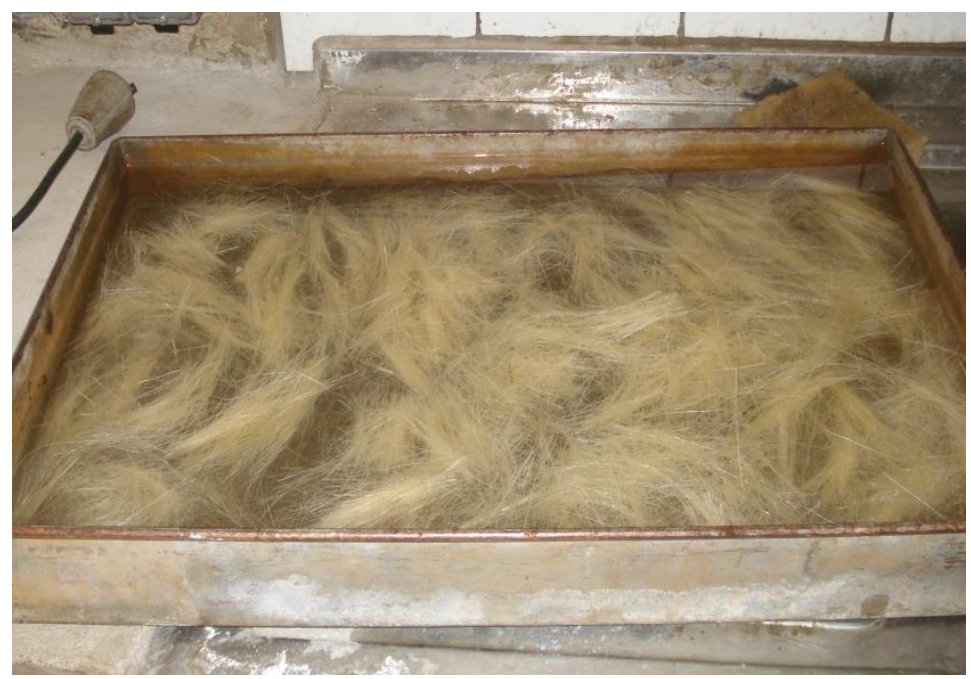

Figura 4.9 - Fibras de sisal imersas em água (Fonte: autor)

Procedeu-se então às determinações de massa em intervalos de 5, 30, 60 e 120 minutos. A partir daí foram feitas as determinações em intervalos de 24 horas até o sexto dia. Para calcular a absorção foi utilizada a equação 13:

$A=\frac{M h t-M s}{M s} \times 100$

Na qual:

A: absorção de água da fibra (\%);

$\mathrm{M}_{\mathrm{ht}}$ : massa úmida da fibra no tempo $\mathrm{t}(\mathrm{g})$;

$\mathrm{M}_{\mathrm{s}}$ : massa seca da fibra de sisal após 24 horas na estufa (g).

\subsection{Caracterização dos materiais empregados no concreto para blocos}

Os ensaios de caracterização dos materiais foram realizados no laboratório seguindo-se as recomendações das normas brasileiras. Os materiais são facilmente encontrados no mercado e foram utilizados nas mesmas condições em que são empregados usualmente na construção civil (Figura 4.10).

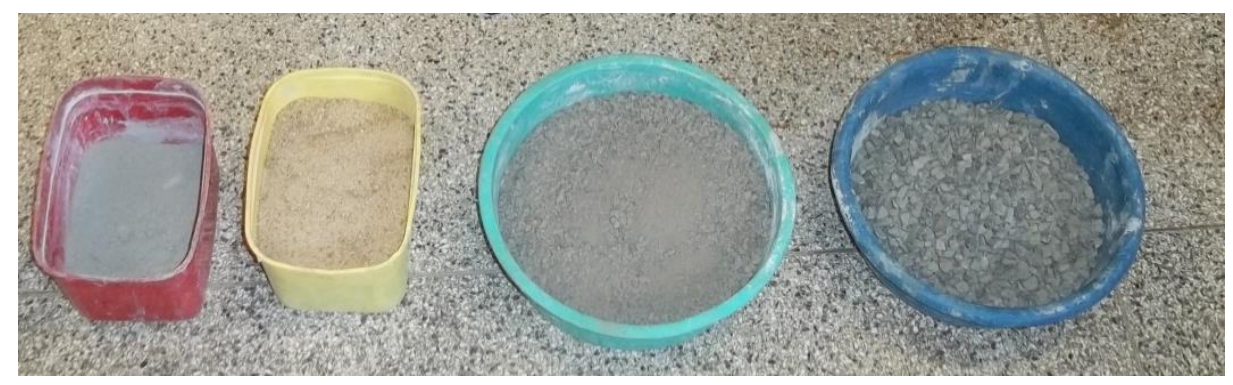

Figura 4.10 - Materiais empregados no concreto para blocos (Fonte: autor) 


\subsubsection{Cimento Portland}

O cimento utilizado foi o CPV ARI RS da marca Holcim. As características físicas, químicas e mecânicas atendem aos requisitos da NBR 5733: 1991 "Cimento Portland de alta resistência inicial". Tal material constitui um tipo particular de cimento Portland que tem a peculiaridade de atingir alta resistência já nos primeiros dias da aplicação. O desenvolvimento da alta resistência inicial é conseguido pela utilização de uma dosagem diferente de calcário e argila na produção do clínquer, bem como pela moagem mais fina do cimento, de modo que, ao reagir com a água, ele adquira elevadas resistências com maior velocidade.

\subsubsection{Agregados miúdo e graúdo}

O agregado miúdo usado foi a areia fina proveniente do Rio Mogi-Guaçu, adquirida na cidade de São Carlos, no estado de São Paulo, e o agregado graúdo foi brita basáltica de graduação zero (pedrisco).

Com a areia e o pedrisco foram adotados os mesmos procedimentos de caracterização realizados para o pó de pedra e utilizados os mesmo equipamentos. Assim, foi determinada massa específica real e aparente, massa unitária solta e compactada e composição granulométrica.

\subsection{Método de dosagem}

Para o desenvolvimento do programa experimental foi utilizado o Método de Dosagem do Menor Volume de Vazios para a definição do esqueleto da mistura e determinação da composição ideal de agregados.

Segundo Rebmann (2011), o procedimento baseia-se no empacotamento dos agregados por meio de misturas sucessivas, visando alcançar um mínimo de vazios possível com as maiores massas unitárias. A busca por um menor volume de vazios tem como objetivo encontrar uma proporção entre agregados que resulte em uma mistura mais compacta, por isso ter relação direta com a resistência à compressão. O empacotamento pode ser empregado em qualquer local e considera a interação entre as partículas reais, inclusive o seu formato e textura superficial.

Descrevem-se a seguir as etapas desse procedimento feitas na pesquisa. Foi feito o empacotamento do agregado graúdo e miúdo: pedrisco e areia.

Tomou-se uma quantidade do pedrisco suficiente para preencher, no estado compactado, o recipiente de três litros utilizado na determinação da massa unitária compactada. Inicialmente realizou-se o preenchimento do recipiente com o pedrisco em três camadas, 
recebendo cada camada compactação com 25 golpes de uma barra de aço $16 \mathrm{~mm}$ (Figura 4.11). Ao final da terceira camada e após o nivelamento da superfície superior, o recipiente foi pesado. A razão entre a massa de material compactado e o volume do recipiente é a massa unitária compactada. Devido à variabilidade no processo de compactação, utilizou-se neste trabalho a média de três medidas.

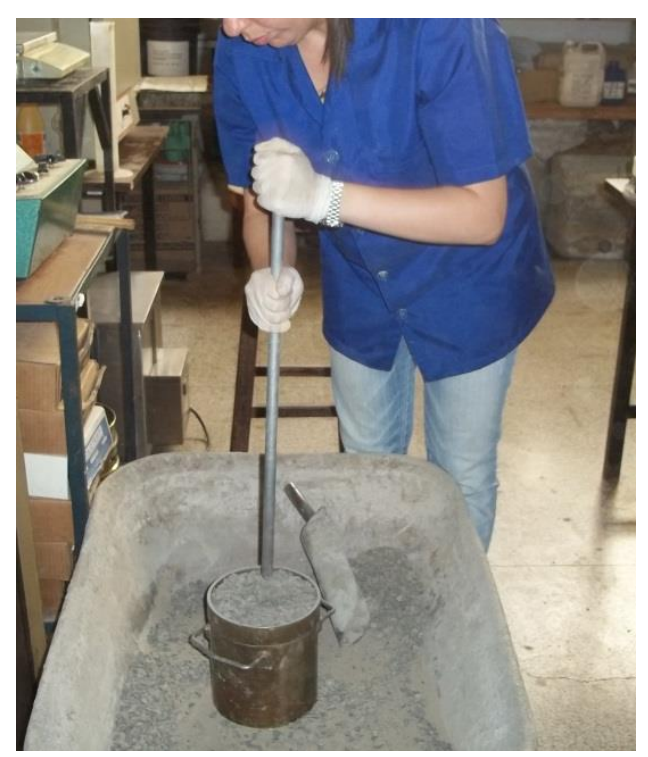

Figura 4.11 - Preenchimento do recipiente com o pedrisco (Fonte: autor)

O passo seguinte foi repetir esse procedimento com misturas de pedrisco e areia em diversas proporções (Figura 4.12). Por razões de economia de material, o pedrisco já utilizado foi reaproveitado, acrescentando-se a quantidade necessária de areia para se obter a proporção desejada. A quantidade a ser acrescentada foi calculada em cada etapa pela equação 14:

$\Delta \mathrm{m}_{\mathrm{B}}^{\mathrm{i}}=\frac{\mathrm{m}_{\mathrm{A}}}{\%_{\mathrm{A}}^{\mathrm{i}}}-\mathrm{m}_{\mathrm{A}}-\mathrm{m}_{\mathrm{B}}^{\mathrm{i}-1}$

Na qual:

$\Delta \mathrm{m}_{\mathrm{B}}^{\mathrm{i}}$ : massa de areia a ser acrescentada na etapa $\mathrm{i}$;

$\mathrm{m}_{\mathrm{A}}$ : massa do pedrisco constante durante o ensaio;

$\mathrm{m}_{\mathrm{B}}^{\mathrm{i}-1}$ : total de pedrisco presente na etapa anterior;

$\%{ }_{\mathrm{A}}^{\mathrm{i}}$ : porcentagem do pedrisco na etapa i. 


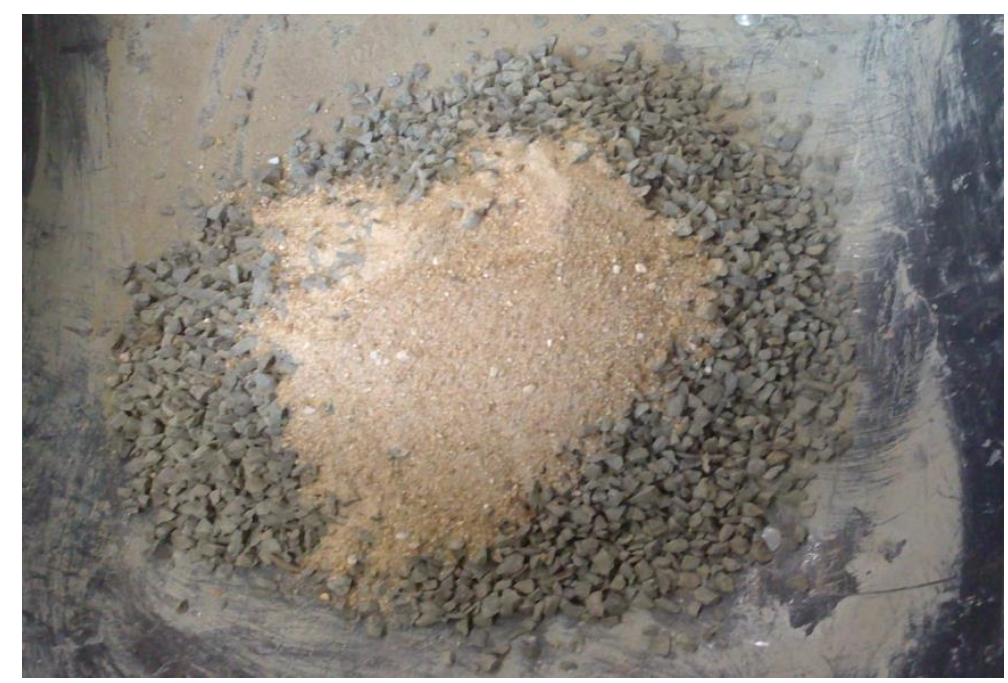

Figura 4.12 - Misturas do pedrisco e da areia em diversas proporções (Fonte: autor)

Observou-se que à medida que a porcentagem de pedrisco foi decrescendo, foram necessários acréscimos cada vez maiores de areia. Todo o espectro de misturas (0 a $100 \%$ ) foi analisado, portanto, realizado em duas partes, partindo-se de $100 \%$ de brita até $50 \%$, acrescentando-se a areia, e depois partindo-se de $100 \%$ da areia e acrescentando pedrisco até $50 \%$. Com isso pôde-se obter a curva completa de empacotamento sem gasto muito grande de material. Para cada mistura realizada obteve-se a massa unitária compactada.

Rebmann (2011) explica que o resultado de massa unitária compactada (M.U.C.) já fornece uma boa ideia do melhor preenchimento dos vazios com material sólido. No entanto, a melhor forma de expressar isso é por meio do índice de vazios. Principalmente quando a densidade dos dois materiais é diferente, podendo ocorrer que o ponto de máxima massa unitária compactada seja diferente do ponto de menor índice de vazios. Devido a isso, optouse neste trabalho por utilizar o índice de vazios na determinação do ponto ótimo de mistura. Conhecendo-se as massas específicas de cada material pôde-se calcular o volume real ocupado pelos sólidos em cada mistura. O índice de vazios (I.V.) é a porcentagem de volume de vazios em relação ao volume total.

Matematicamente, isso pode ser expresso pela equação 15:

I. V $=100 \%-\left(\frac{\%_{A}}{\gamma_{A}}+\frac{\%_{B}}{\gamma_{B}}\right) *($ M. U. C. $)$

Na qual:

$\%_{\mathrm{A}}$ : porcentagem do pedrisco;

$\%_{\mathrm{B}}$ : porcentagem da areia;

$\gamma_{\mathrm{A}}$ : massa específica do pedrisco;

$\gamma_{\mathrm{B}}$ : massa específica da areia; 
M. U. C.: massa unitária compactada da mistura.

Os resultados para cada uma das composições encontram-se na Tabela 4.3.

Tabela 4.3 - Resultados de massa unitária e volume de vazios para cada uma das composições de pedrisco e areia (Fonte: autor)

\begin{tabular}{ccccc}
\hline \multicolumn{5}{c}{ \% Pedrisco } \\
\% Areia & $\begin{array}{c}\text { Massa da } \\
\text { mescla } \\
\text { compactada (g) }\end{array}$ & M.U.C (g/l) & I.V (\%) \\
\hline 100 & 0 & 4739,80 & 1579,93 & 44,76 \\
90 & 10 & 4915,00 & 1638,33 & 42,23 \\
80 & 20 & 5310,50 & 1770,17 & 37,05 \\
70 & 30 & 5629,00 & 1876,33 & 32,70 \\
60 & 40 & 5805,50 & 1935,17 & 30,30 \\
50 & 50 & 5840,50 & 1946,83 & 29,40 \\
40 & 60 & 5752,50 & 1917,50 & 28,90 \\
30 & 70 & 5557,50 & 1852,50 & 30,20 \\
20 & 80 & 5393,00 & 1797,67 & 32,62 \\
10 & 90 & 5197,00 & 1732,33 & 34,48 \\
0 & 100 & 4937,00 & 1645,67 & 37,19 \\
\hline
\end{tabular}

O resultado da mistura de pedrisco e areia em termos de índice de vazios é apresentado na Figura 4.13. A conclusão do ensaio foi que a melhor proporção entre pedrisco e areia corresponde a $40 \%$ de pedrisco e $60 \%$ de areia. Nessa condição restam ainda $28,90 \%$ de vazios, volume esse a ser preenchido com a pasta de cimento.

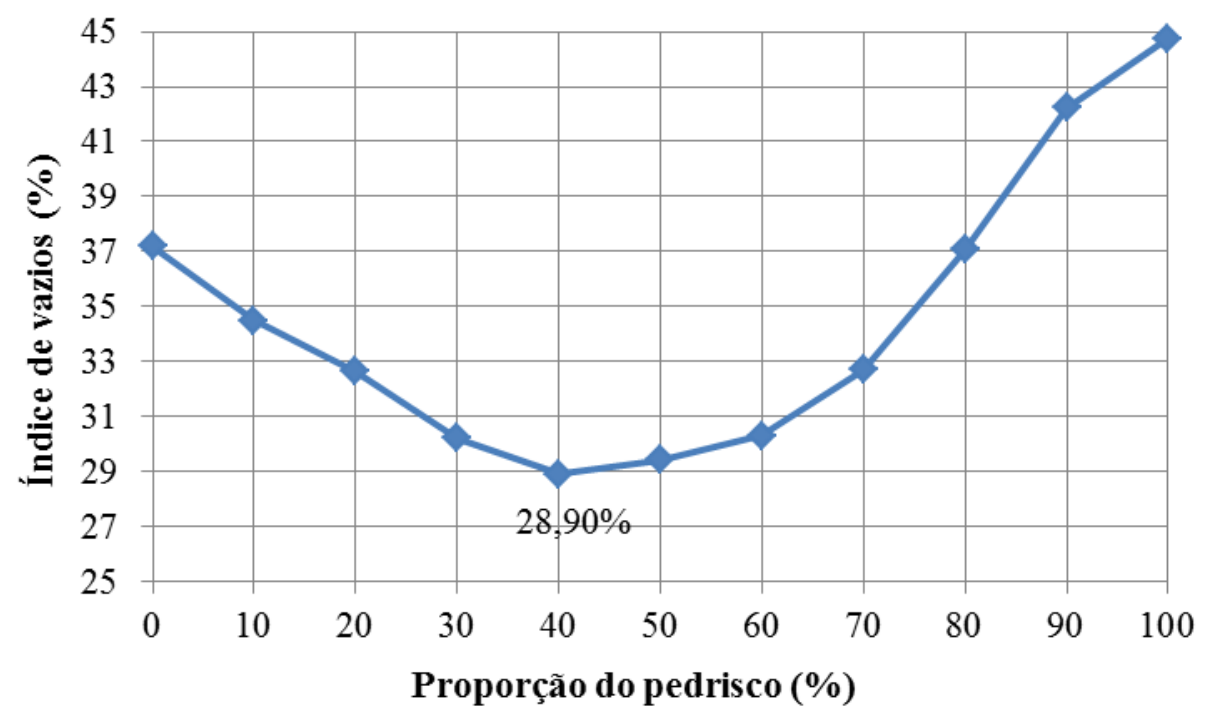

Figura 4.13 - Curva do menor volume de vazios das composições pedrisco e areia (Fonte: autor) 
As dosagens utilizadas para cada traço: 1:15, 1:10 e 1:6 (pobre, médio e rico), com a finalidade de produzir blocos estruturais das classes de resistência de 4, 8 e $12 \mathrm{Mpa}$, respectivamente, são apresentadas na Tabela 4.4 .

Tabela 4.4 - Composições de materiais para $1 \mathrm{~m}^{3}$ (Fonte: autor)

\begin{tabular}{cccc}
\hline \multirow{2}{*}{ Materiais } & \multicolumn{3}{c}{ Relação cimento/agragado } \\
\cline { 2 - 4 } & $\mathbf{1 : 1 5}$ & $\mathbf{1 : 1 0}$ & $\mathbf{1 : 6}$ \\
\hline Cimento (kg) & 141,00 & 205,20 & 322,10 \\
Pedrisco (kg) & 846,06 & 820,52 & 773,14 \\
Areia (kg) & 1269,09 & 1230,78 & 1159,70 \\
Água (kg) & 143,80 & 143,60 & 144,90 \\
Fator a/c & 1,02 & 0,70 & 0,45 \\
Traço em massa (c:a:p) & $1: 9: 6$ & $1: 6: 4$ & $1: 3.6: 2.4$ \\
Teor de argamassa (\%) & 62,5 & 63,6 & 65,7 \\
Umidade (\%) & & 6,0 & \\
Módulo de finura da mistura & & 3,63 & \\
\hline
\end{tabular}

Nota-se na Tabela 4.4 que a umidade para todos os traços foi fixada em 6,0\%, em relação à quantidade total de materiais secos.

\subsection{Produção de corpos de prova cilíndricos $(5 \mathrm{~cm} \times 10 \mathrm{~cm})$}

Em um estudo piloto foram produzidos corpos de prova cilíndricos $(5 \mathrm{~cm} \times 10 \mathrm{~cm})$ utilizando-se concreto de consistência seca de característica similar ao empregado nos blocos estruturais (Figura 4.14). O objetivo foi avaliar as porcentagens ideais dos pós residuais no concreto para, segundo os resultados obtidos, proceder à fabricação dos blocos. Assim foram avaliadas características do concreto, como coesão, massa específica, absorção de água, índice de vazios e resistência à compressão. Esse estudo foi um excelente indicativo das características que serão obtidas nos blocos com e sem adição de resíduos. Julgou-se fundamental o desenvolvimento de fôrmas cilíndricas de $5 \mathrm{~cm}$ x $10 \mathrm{~cm}$ que possibilitassem uma moldagem rápida e, principalmente, uma desforma precisa e rápida, sem comprometer a integridade do corpo de prova. Além disso, elas permitem a produção de grande quantidade de corpos consumindo menos material, sem a necessidade de uma prensa hidráulica, necessária para moldar fôrmas maiores. $\mathrm{O}$ total de corpos de prova foi oito para cada tipo de concreto, totalizando 240 exemplares. 


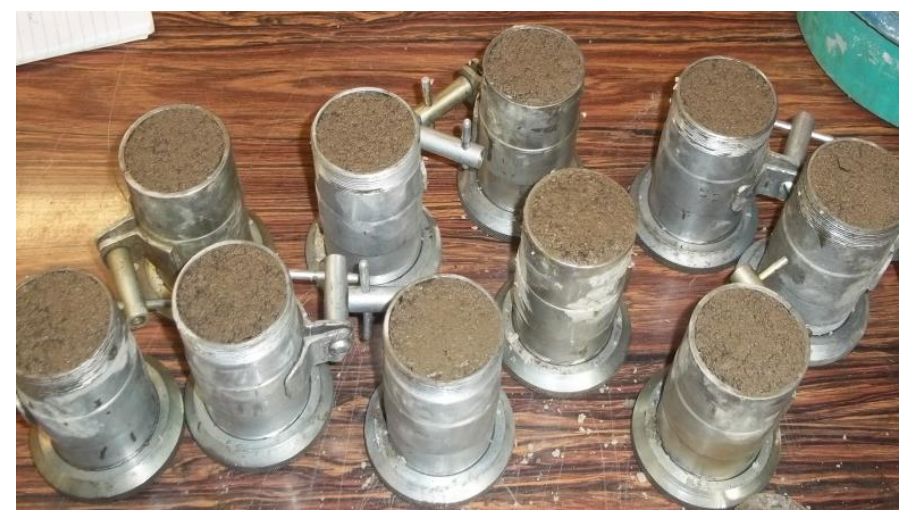

Figura 4.14 - Moldagem de corpos de prova cilíndricos $(5 \mathrm{~cm}$ x $10 \mathrm{~cm})$ (Fonte: autor)

A primeira finalidade desse estudo foi avaliar a substituição da areia natural por pó de pedra com teores de 0\%, 20\%, 40\%, 60\% e 80\% para cada um dos traços (pobre, médio e rico). Com o estudo estatístico por meio da Técnica do Bootstrap foi determinada a porcentagem ideal do rejeito de britagem. A Tabela 4.5 apresenta a nomenclatura adotada para cada série de concreto produzida.

Tabela 4.5 - Dados da moldagem dos corpos de prova com substituição do pó de pedra (Fonte: autor)

\begin{tabular}{|c|c|c|c|c|c|c|}
\hline \multicolumn{7}{|c|}{ Teores de Pó de Pedra substituindo a areia } \\
\hline Grupo/Traço & $0 \%$ & $20 \%$ & $40 \%$ & $60 \%$ & $80 \%$ & Comentário \\
\hline GRUPO 4/1:15 & 4-REF & 4-P.P20 & 4-P.P40 & 4-P.P60 & 4-P.P80 & $\begin{array}{l}\text { Relação } \\
\text { cimento/agregado } 1: 15 \\
\text { e fbk }=4 \mathrm{MPa}\end{array}$ \\
\hline GRUPO 8/1:10 & 8-REF & 8-P.P20 & 8-P.P40 & 8-P.P60 & 8-P.P80 & $\begin{array}{l}\text { Relação } \\
\text { cimento/agregado } \quad 1: 10 \\
\text { e fbk }=8 \mathrm{MPa}\end{array}$ \\
\hline GRUPO 12/1:6 & 12-REF & 12-P.P20 & 12-P.P40 & 12-P.P60 & 12-P.P80 & $\begin{array}{l}\text { Relação } \\
\text { cimento/agregado } 1: 6 \mathrm{e} \\
\text { fbk }=12 \mathrm{MPa}\end{array}$ \\
\hline
\end{tabular}

Com a proporção de pó de pedra que gerou as melhores características mecânicas no concreto precedeu-se à fabricação de corpos empregando-se substituições do cimento por pó de resíduo orgânico com teores de $0 \%, 5 \%, 10 \%, 15 \%$ e 20\% (Tabela 4.6). O estudo estatístico foi novamente empregado, para contribuir na tomada de decisões e obter a porcentagem de pó de resíduo que originou o concreto com melhor comportamento mecânico. 
Tabela 4.6 - Dados da moldagem dos corpos de prova com substituição do pó de resíduo (Fonte: autor)

\begin{tabular}{ccccccc}
\hline \multicolumn{7}{c}{ Teores de pó de resíduo substituindo o cimento } \\
\hline Grupo/Traço & $\mathbf{0 \%}$ & $\mathbf{5 \%}$ & $\mathbf{1 0 \%}$ & $\mathbf{1 5 \%}$ & $\mathbf{2 0 \%}$ & Comentário \\
\hline GRUPO 4/1:15 & 4-REF & 4-P.L5 & 4-P.L10 & 4-P.L15 & 4-P.L20 & $\begin{array}{l}\text { Relação } \\
\text { cimento/agregado 1:15 e } \\
\text { fibk = MPa } \\
\text { Relação } \\
\text { cimento/agregado 1:10 e } \\
\text { fik = 8 MPa } \\
\text { Relação } \\
\text { cimento/agregado 1:6 e } \\
\text { fik =12 MPa }\end{array}$ \\
\hline
\end{tabular}

Todas as misturas foram realizadas na argamasseira mecânica marca G. Paniz. Os materiais foram misturados à temperatura de $25 \pm 3{ }^{\circ} \mathrm{C}$ e umidade relativa do ar de $55 \pm 15 \%$, até a obtenção de uma mistura homogênea, durante cinco minutos aproximadamente.

A ordem de colocação dos materiais foi a seguinte:

$1^{\text {a }}$ - Mistura e homogeneização dos agregados graúdo e miúdo, incluindo-se o pó de pedra no caso do concreto com adição desse resíduo;

$2^{\mathrm{a}}$ - Adição de metade da quantidade de água prevista;

$3^{\mathrm{a}}$ - Adição do cimento, incluindo-se o pó de resíduo no caso do concreto com adição desse resíduo, e homogeneização da mistura;

$4^{\mathrm{a}}$ - Incorporação do sisal no caso dos concretos reforçados com a fibra;

$5^{\mathrm{a}}$ - Adição do restante da água e homogeneização final da mistura.

Durante o processo de mistura e produção dos corpos de prova foram registradas a temperatura e a umidade no ambiente do laboratório. $\mathrm{O}$ processo de mistura pode ser visualizado na Figura 4.15.

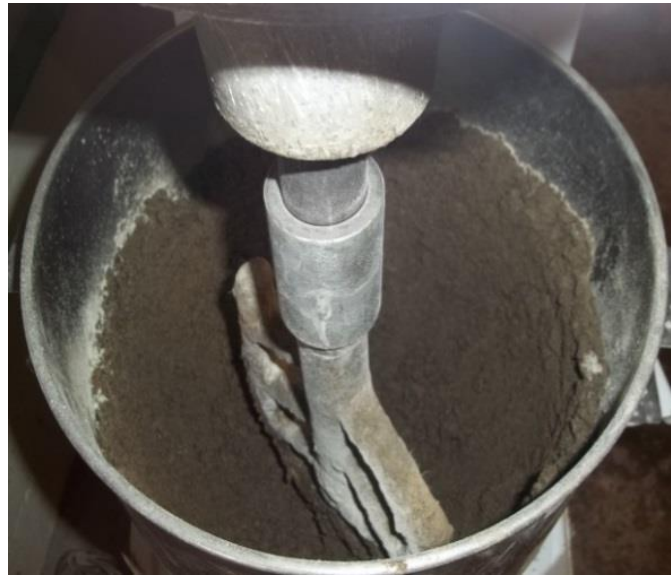

(a)

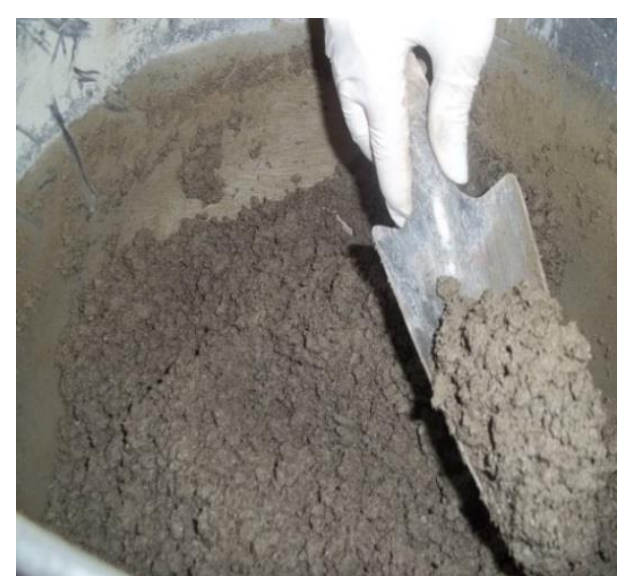

(b)

Figura 4.15 - Mistura do concreto: (a) mistura dos materiais e (b) homogeneização final do concreto (Fonte: autor) 
Com relação à compactação dos corpos de prova cilíndricos (quantidade de golpes com haste metálica), foi estabelecido 20 golpes em quatro camadas. A força aplicada nos golpes com o soquete foi igualmente distribuída em cada camada. Segundo Buttler (2007), essa energia de adensamento deve equilibrar a energia de compactação utilizada nas vibroprensas para a fabricação dos blocos, conferindo maior compacidade à mistura (Figura 4.16).

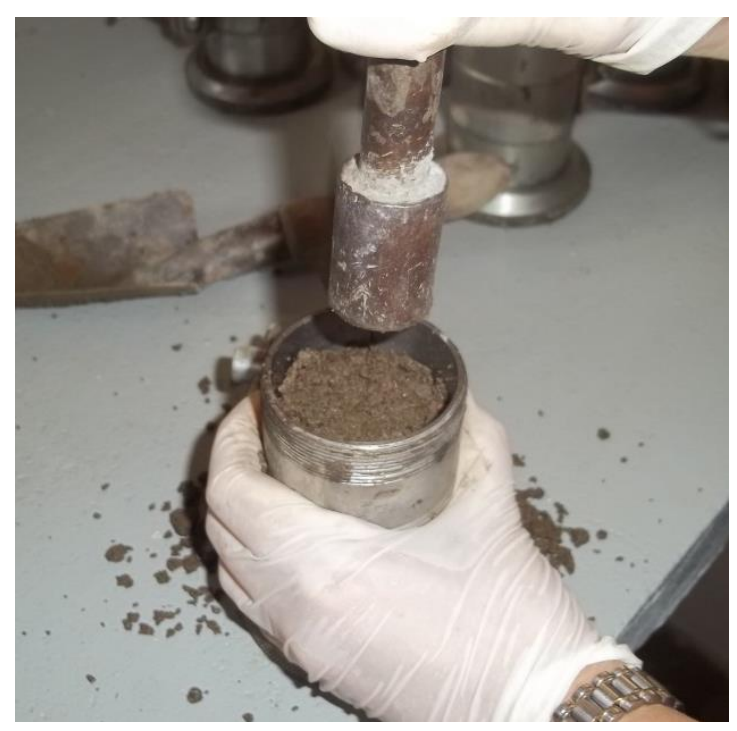

Figura 4.16 - Compactação de 20 golpes em quatro camadas (Fonte: autor)

Após a moldagem, todos os corpos de prova foram pesados e depois colocados na câmara úmida até a data de ensaio.

As principais propriedades físicas e mecânicas dos corpos de prova cilíndricos analisadas encontram-se na Tabela 4.7.

Tabela 4.7 - Ensaios referentes ao concreto fresco e endurecido dos corpos de prova (Fonte: autor)

\begin{tabular}{ll}
\hline Propriedades & Norma \\
\hline Massa específica fresca & NBR 9833:2008 \\
$\begin{array}{l}\text { Absorção de água, massa } \\
\text { específica e índice de vazios }\end{array}$ & NBR 9778:2009 \\
$\begin{array}{l}\text { Resistência à compressão axial } \\
\text { Coesão da mistura }\end{array}$ & NBR 5739: 2007 \\
\hline
\end{tabular}

O ensaio de coesão deve-se realizar, principalmente, em situações mais críticas como traços com pouco consumo de cimento. A coesão do concreto para a fabricação de blocos vai influenciar nas etapas de transporte das unidades recém-produzidas (transporte manual, emprego de empilhadeiras, etc). 
Segundo Prudêncio, Oliveira e Frasson (2000), a coesão do concreto fresco é determinada comprimindo-se diametralmente os corpos de prova cilíndricos recém-moldados. Para tal, dois corpos de prova são dispostos sobre uma superfície horizontal, em paralelo segundo seus eixos longitudinais, distanciados de $30 \mathrm{~cm}$ (eixo a eixo). Sobre os referidos corpos de prova é posicionada uma chapa plana de madeira de $50 \mathrm{~cm}$ x $20 \mathrm{~cm}$ e espessura mínima de 1,5 cm, cujo objetivo é servir de elemento de transferência de carga. Sobre a chapa de madeira é posicionado um recipiente a ser preenchido com água, de forma a gerar um carregamento uniforme de aproximadamente $1 \mathrm{~kg} / \mathrm{s}$. $\mathrm{O}$ ensaio mede a carga necessária para esmagamento dos dois corpos de prova de $5 \mathrm{~cm}$ x $10 \mathrm{~cm}$ que servem de apoio, conforme se verifica no detalhe apresentado na Figura 4.17. Segundo recomendação de Frasson Júnior (2000), valores de coesão superiores a 6 kg significam que as misturas são apropriadas para a produção de blocos de concreto. Por outro lado, Prudêncio, Oliveira e Frasson (2000) recomenda valores que estejam entre 5 e $8 \mathrm{~kg}$.
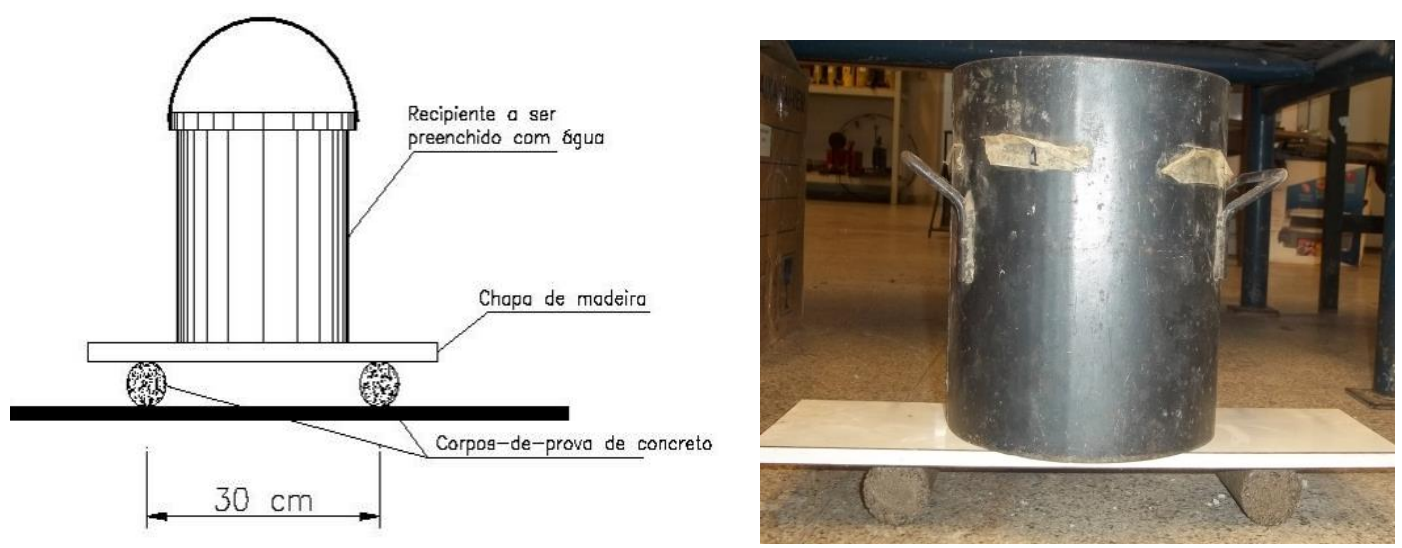

Figura 4.17 - Esquema e foto de ensaio para avaliação da coesão das misturas (Fonte: autor).

Nos ensaios de absorção de água, massa específica e índice de vazios (propriedades físicas dos corpos de prova) foram utilizados os seguintes equipamentos: estufa da marca Quimis, balança da marca Mettler com precisão de 0,1 g e capacidade de 24000 g. O ensaio de resistência à compressão foi realizado na máquina computadorizada marca ELE Modelo Autotest. A superfície dos corpos foi retificada por meio de máquina adequada para esse tratamento, resultando em superfícies bem regulares e lisas. Na Figura 4.18 são apresentados alguns detalhes desses ensaios, bem como dos equipamentos utilizados. 


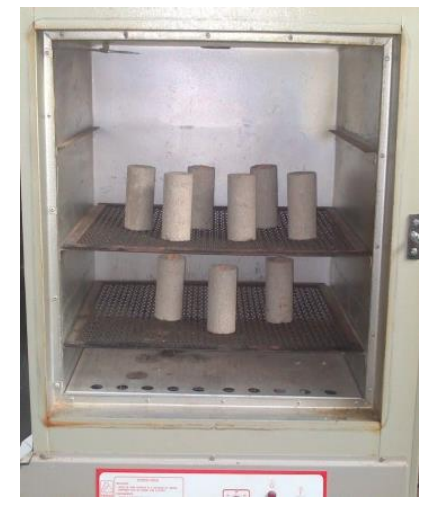

(a)

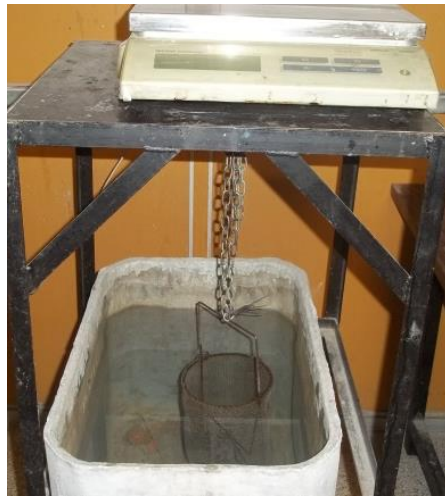

(b)

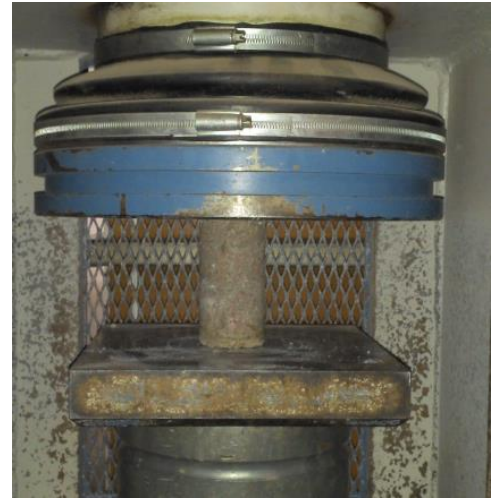

(c)

Figura 4.18 - Execução dos ensaios referentes às propriedades físicas dos corpos de prova: (a) secagem na estufa, (b) determinação da massa imersa na balança hidrostática e (c) ensaio de compressão na máquina ELE (Fonte: autor)

\subsection{Fabricação dos blocos de concreto}

Os blocos modificados com os pós residuais e a fibra foram fabricados no Laboratório de Estruturas por meio do uso de uma vibroprensa corretamente equipada. Dessa forma foi possível obter melhor controle no processo de produção, contribuindo para o correto desenvolvimento da pesquisa.

A máquina de blocos de marca Makipen Modelo Pen 200 tem capacidade de produção de até 2000 blocos de 14 × 19 × $39 \mathrm{~cm}$ em oito horas. É definida como uma máquina semiautomática dotada de mesa vibratória para o preenchimento de concreto na fôrma (Figura 4.19). A vibração é dada por dois eixos excêntricos de alta rotação banhados a óleo e acionados por motor trifásico de 3 HP. Uma das suas características principais é a energia de compactação utilizada na vibração, a qual é adequada para se obterem blocos com a resistência desejada, bom acabamento, consistência rija e bom adensamento do concreto. 


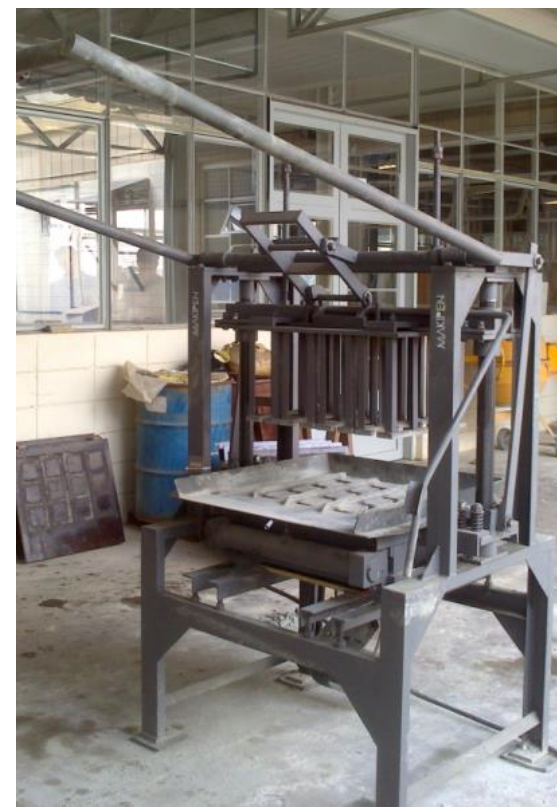

Figura 4.19 - Vibroprensa Makipen utilizada para a fabricação dos blocos no laboratório (Fonte: autor)

Foram fabricadas diferentes séries de blocos diferenciadas pelas porcentagens ideais dos pós substituindo o cimento e a areia, e pelo comprimento e teor de fibras adicionado em relação ao volume do concreto. A partir dos resultados obtidos nos ensaios dos corpos de prova cilíndricos, foram definidas oito séries de blocos como mostra a Tabela 6.1 e para cada série foram fabricados 72 blocos, totalizando 576 unidades.

Materiais como os agregados e o cimento foram recebidos e armazenados em lugares adequados no laboratório: baias de armazenagem para o pedrisco, o pó de pedra e a areia e sacos para cimento, colocado em uma área fechada a temperatura ambiente. Todos os insumos foram dosados em massa para se ter um maior controle e maior qualidade na produção das unidades.

No preparo do concreto foi utilizado um misturador mecânico de eixo vertical, cuba fixa e pás móveis com capacidade aproximada de $300 \mathrm{~kg}$. O tempo mínimo de mistura foi de três minutos, suficiente para obtenção da perfeita homogeneidade do concreto.

Esta foi a ordem de colocação dos materiais:

$1^{\text {a }}$ - Dosagem e mistura de todos os agregados;

$2^{\mathrm{a}}$ - Adição de metade da quantidade de água prevista;

$3^{\mathrm{a}}$ - Introdução do cimento, incluindo-se o pó residual orgânico, no caso dos blocos com adição desse resíduo, e as fibras, no caso das unidades reforçadas com sisal;

$5^{\mathrm{a}}$ - Mistura dos materiais durante um minuto;

$6^{\mathrm{a}}$ - Adição do restante da água e homogeneização final da mistura. 
Depois da mistura, o concreto foi despejado em um carrinho de mão com caçamba metálica. Esse foi posicionado na frente da máquina ligada e com o uso de uma pá de bico foi colocado o material na mesa vibratória para o preenchimento da fôrma. Após o concreto encher a matriz, o excesso foi retirado com um rastelo e a seguir a trava foi solta da prensa para que as hastes metálicas ou contramoldes comprimissem e compactassem a massa no interior da fôrma. O braço da máquina foi abaixado para elevar a caixa da matriz e assim retirar os blocos prontos. Finalizada a prensagem, os blocos recém-moldados foram transferidos para o interior da câmara de cura úmida e estocados no pátio do laboratório até a data dos ensaios. A sequência desse processo é mostrada na Figura 4.20.

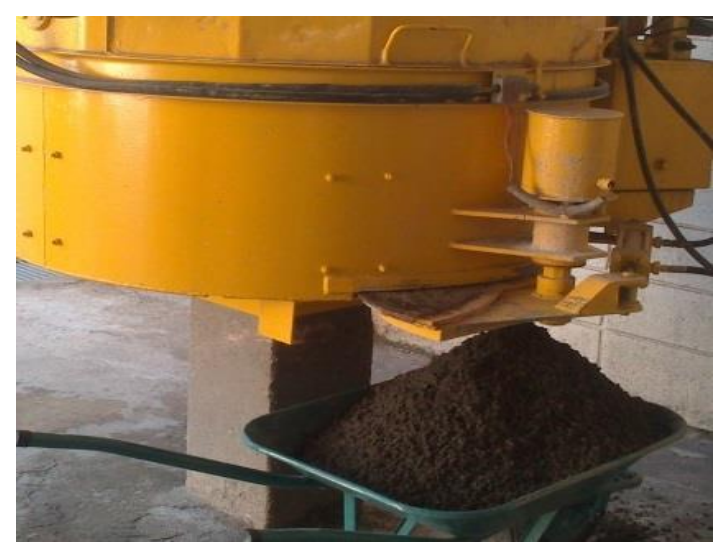

(a)

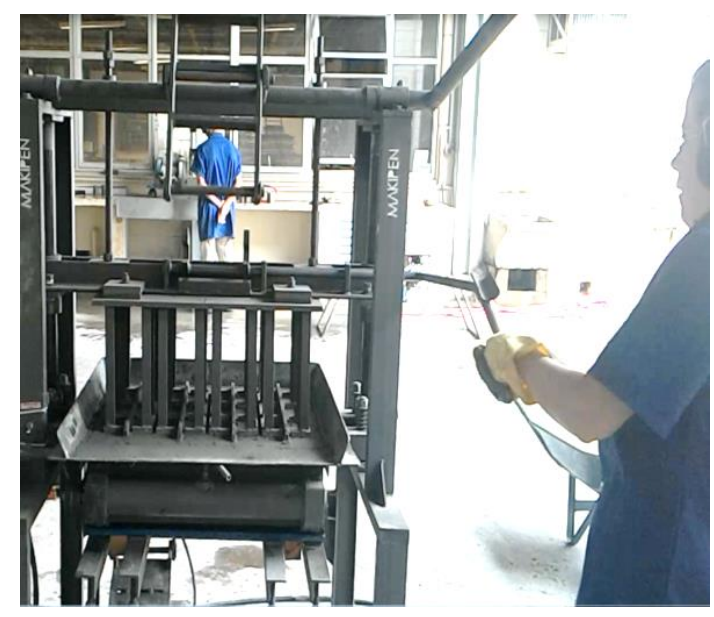

(c)

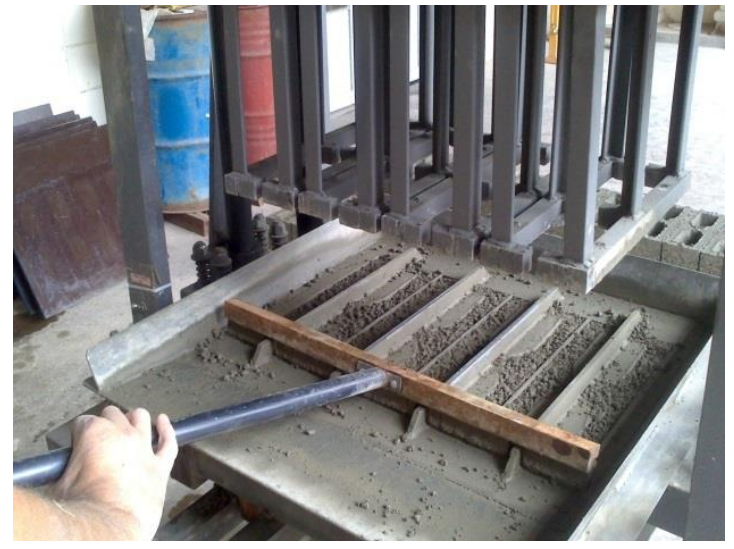

(b)

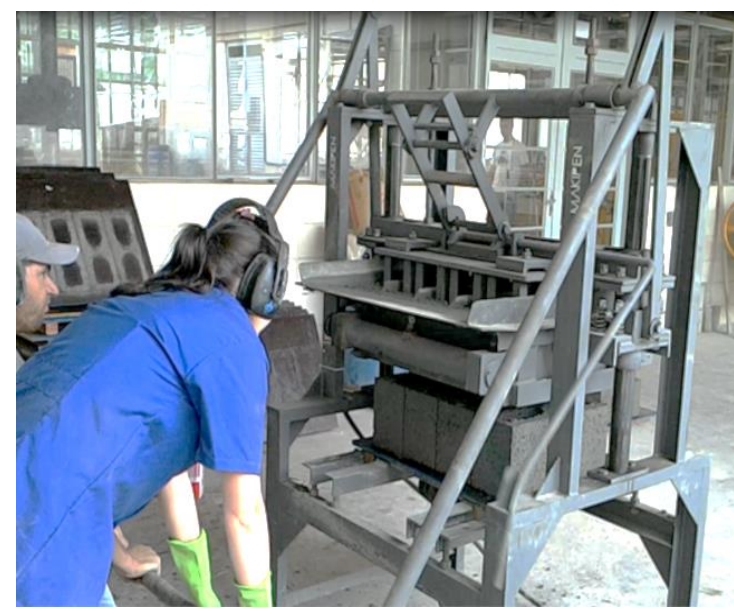

(d) 


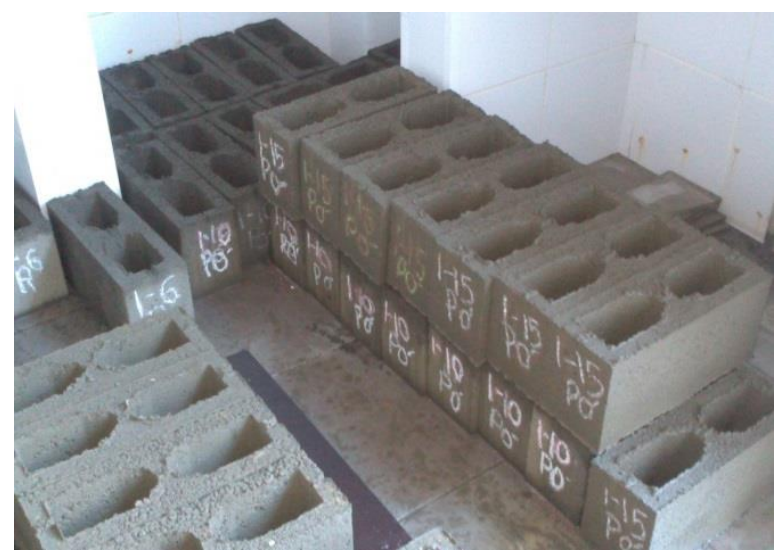

(e)

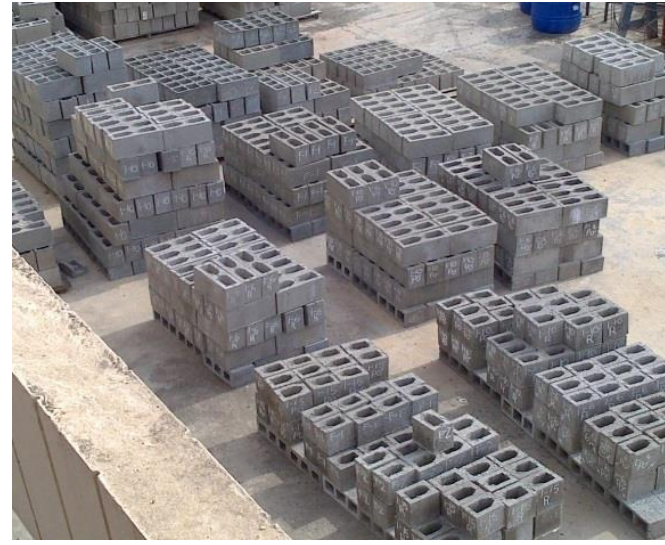

(f)

Figura 4.20 - Sequência na execução dos blocos estruturais: (a) concreto despejado no carrinho de mão, (b) retirada do excesso de concreto com o uso de um rastelo, (c) hastes metálicas comprimindo e compactando a massa no interior da fôrma, (d) descida do braço da máquina para a elevação da caixa da matriz e retirada dos blocos, (e) cura dos blocos na câmera úmida e (f) blocos estocados no pátio do laboratório até a data dos ensaios (Fonte: autor)

O tempo de alimentação da fôrma, vibração, compactação e desforma foram definidos de acordo com o critério visual da pesquisadora, mas de maneira geral foi em torno de três minutos para cada tipo de blocos. Quando a primeira chapa de blocos não era produzida corretamente, ou seja, se havia coesão insuficiente, quebra de cantos e altura superior à especificada, eram ajustados novos tempos de produção.

A fabricação dos meios blocos seguiu a mesma sequência dos blocos inteiros, mas foi necessário colocar na vibroprensa a fôrma adequada para produzir este tipo de unidade, a qual é usada na fabricação das pequenas paredes. Foram feitos 12 meio-blocos para cada série de bloco (oito), totalizando 96 elementos.

\subsection{Avaliação e caracterização dos blocos}

O bom desempenho das unidades é garantido desde que atendam aos limites impostos pelas normas técnicas quanto às propriedades físicas e mecânicas, como análise dimensional, absorção de água, teor de umidade, área líquida, massa específica, resistência à compressão e módulo de deformação. Essa investigação engloba principalmente uma análise comparativa entre as características dos blocos produzidos com os materiais não convencionais (fibras de sisal, pó de resíduo orgânico e pó de pedra) e os blocos de referência. A retração dos blocos não será tratada nesta pesquisa, sendo estudada em trabalhos futuros. 


\subsubsection{Análise dimensional}

Seguindo as prescrições da norma NBR 6136: 2014 foram controlados os aspectos visuais dos blocos, não apresentando defeitos sistemáticos, como trincas, rachaduras, quebras, superfícies irregulares ou deformações que impeçam a sua utilização.

Os blocos foram fabricados com fôrmas de modo que apresentem dimensões de 140 mm x 190 mm x 390 mm (largura, altura, comprimento). Segundo a norma, as tolerâncias são de $\pm 2 \mathrm{~mm}$ para a largura e $\pm 3 \mathrm{~mm}$ para a altura e o comprimento. As espessuras das paredes transversais e longitudinais devem ser de no mínimo $25 \mathrm{~mm}$ para os blocos estruturais da classe M-15 e a menor dimensão dos furos devem ser $\geq 70 \mathrm{~mm}$.

Para cada série de blocos foi utilizada uma amostra de seis blocos, escolhidos aleatoriamente para determinar largura, comprimento, altura, espessura mínima das paredes e dimensões dos furos. Assim, para cada uma dessas dimensões foram anotadas pelo menos três medidas em pontos distintos de cada face, sendo necessário o uso de uma régua metálica com graduação de $1 \mathrm{~mm}$, um esquadro metálico de $90^{\circ}$ e um paquímetro digital com precisão de 0,1 mm. A dimensão final foi obtida pela média dessas medições. Na Figura 4.21 são apresentadas algumas imagens quando foi realizada a análise dimensional.

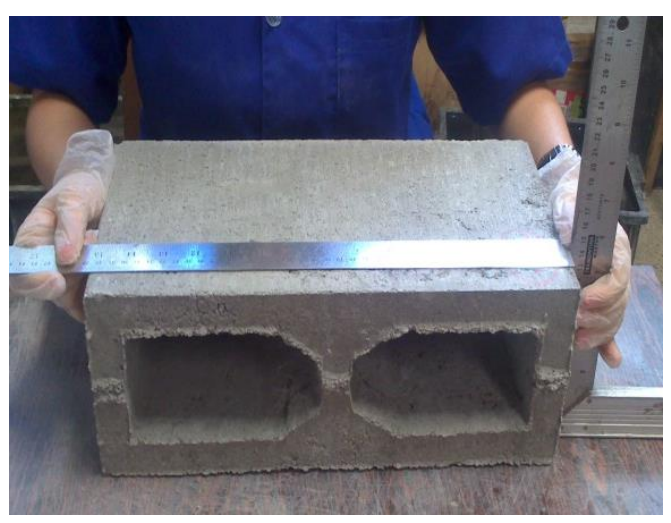

(a)

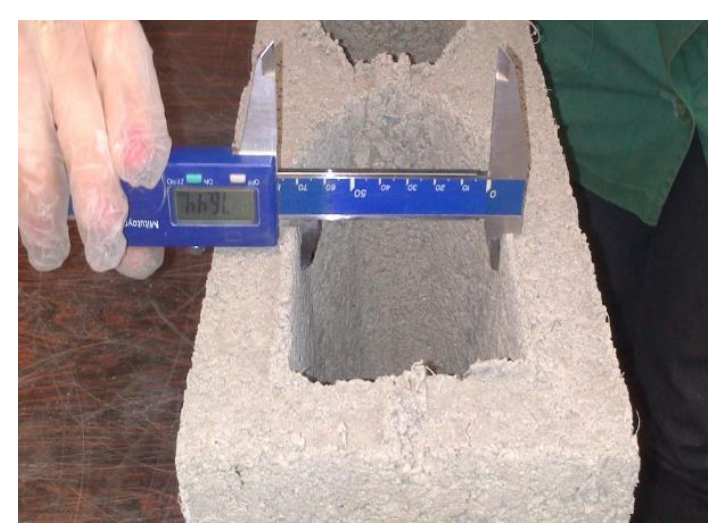

(b)

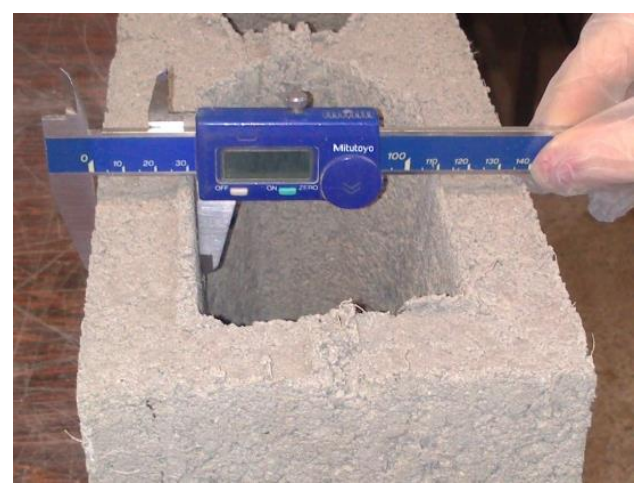

(c)

Figura 4.21 - Execução da análise dimensional nos blocos: (a) medição do comprimento, (b) medição da menor dimensão dos furos e (c) medição da espessura das paredes (Fonte: autor) 


\subsubsection{Absorção de água e área líquida}

O processo de ensaio para a determinação da absorção de água e da área líquida foi baseado na NBR 12118: 2013. Para cada série de blocos foi ensaiada uma amostra de três unidades.

Após da estocagem dos blocos no pátio do laboratório, os mesmos foram pesados em uma balança de marca Mettler Toledo, obtendo-se assim a massa denominada $\mathbf{M}_{3}$ (Figura 4.22).

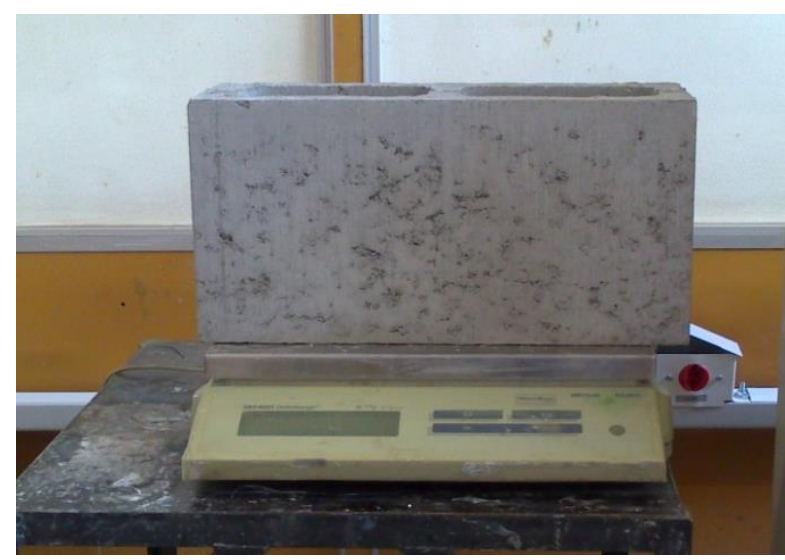

Figura 4.22 - Pesagem dos blocos na balança (Fonte: autor)

Em seguida, as unidades foram levadas à estufa a uma temperatura de $110 \pm 5^{\circ} \mathrm{C}$ para o processo de secagem, permanecendo lá por 24 horas, conforme especifica a NBR 12118: 2013. Após o resfriamento, cada bloco teve sua massa determinada e foram colocados novamente na estufa por duas horas. A operação de pesagem dos blocos resfriados foi repetida, verificando para que a diferença de massa seja inferior a $0,5 \%$ da anterior. $\mathrm{O}$ valor da massa seca foi anotado e denominado como $\mathrm{M}_{1}$ (Figura 4.23).

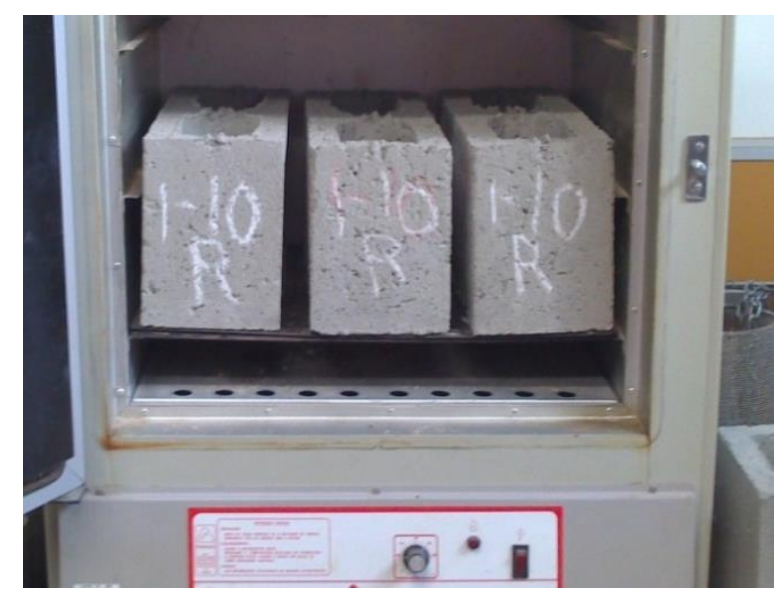

Figura 4.23 - Blocos sendo secados na estufa (Fonte: autor) 
Posteriormente, os blocos foram imersos em água a uma temperatura de $(23 \pm 5)^{\circ} \mathrm{C}$ por 24 horas. Depois, as unidades foram retiradas da água, pesadas e imersas novamente em água. Essa operação se repete a cada duas horas até que em duas pesagens sucessivas não ocorra registro de diferença de massa superior a $0,5 \%$. Dessa forma foi obtida a massa saturada denominada $\mathrm{M}_{2}$ (Figura 4.24).

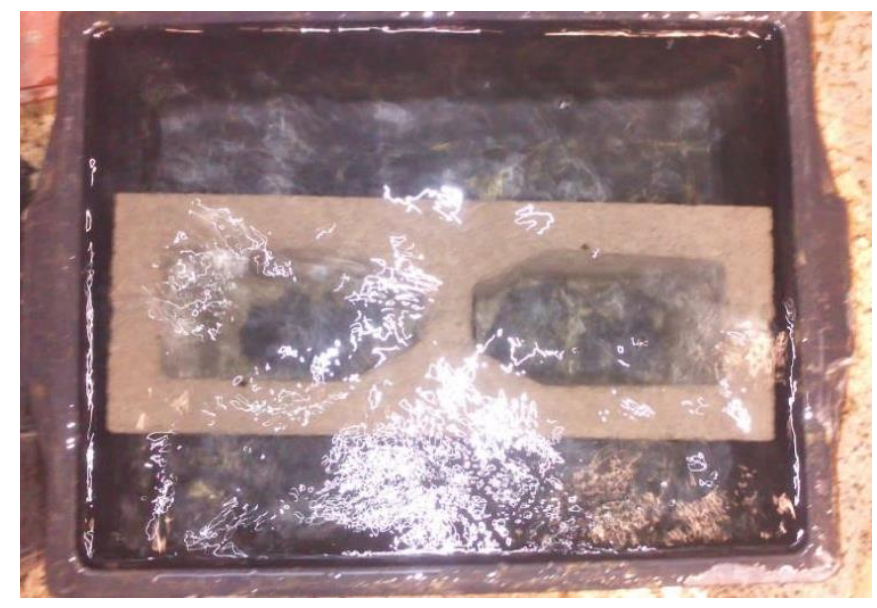

Figura 4.24 - Blocos imergidos em água (Fonte: autor)

O valor da absorção de água, expresso em porcentagem de cada bloco (A\%), é calculado por meio da equação 16 :

$$
A=\frac{M_{2}-M_{1}}{M_{1}} \times 100
$$

Na qual:

A: absorção de água dos blocos (\%);

$\mathrm{M}_{1}$ : massa do bloco seco em estufa $(\mathrm{g})$;

$\mathrm{M}_{2}$ : massa do bloco saturado (g).

A NBR 6136: 2014 especifica que para blocos de concreto com função estrutural a absorção de água deve ser menor ou igual a $10 \%$.

A área líquida foi obtida por meio do peso submerso do bloco e do consequente cálculo do empuxo produzido, ou seja, volume de líquido deslocado. A divisão entre o volume de líquido deslocado e a altura do bloco fornece a área líquida média como mostra a equação 17. A altura do bloco e o valor de $\mathrm{M}_{2}$ foram obtidos como explicado nos itens anteriores. $\mathrm{O}$ bloco saturado foi imerso em água à temperatura de $\left(23 \pm 5^{0} \mathrm{C}\right)$ por meio da balança hidrostática (Figura 4.225) e o valor encontrado foi denominado massa aparente $\mathrm{M}_{4}$. 


$$
A_{l i q}=\frac{M_{2}-M_{4}}{H \times \rho_{a}} \times 1000
$$

Na qual:

$\mathrm{A}_{\text {liq }}$ : área líquida dos blocos $\left(\mathrm{mm}^{2}\right)$;

$\mathrm{M}_{2}$ : massa do bloco saturado (g);

$\mathrm{M}_{4}$ : massa aparente do bloco (g);

$\mathrm{H}$ : altura média do bloco $(\mathrm{mm})$;

$\rho_{\mathrm{a}}$ : massa específica da água $\left(\mathrm{g} / \mathrm{cm}^{3}\right)$.

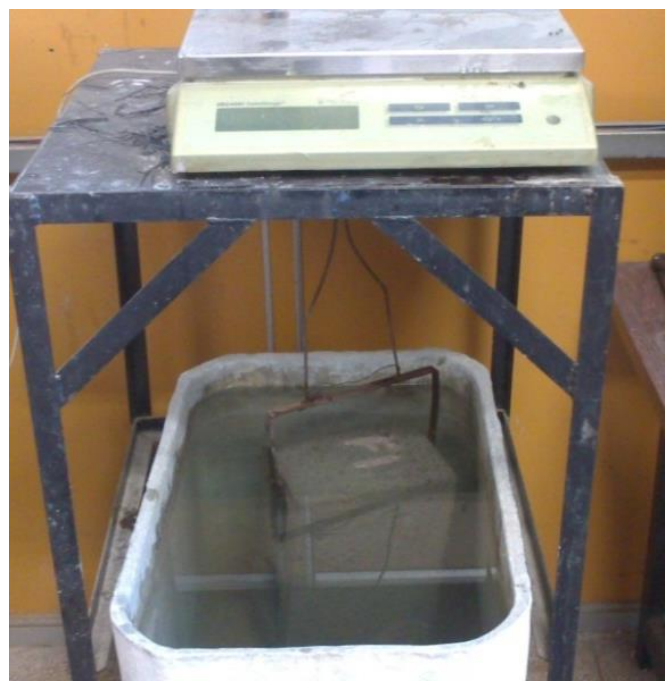

Figura 4.25 - Massa dos blocos determinada por meio da balança hidrostática (Fonte: autor)

\subsubsection{Teor de umidade}

A porcentagem de umidade de cada unidade foi determinada conforme ao descrito por Romagna (2000), por meio da equação 18:

$$
U=\frac{M_{3}-M_{1}}{M_{2}-M_{1}} \times 100
$$

na qual:

$\mathrm{U}$ : umidade dos blocos (\%);

$\mathrm{M}_{3}$ : massa do bloco seco ao ar (g);

$\mathrm{M}_{1}$ : massa do bloco seco em estufa $(\mathrm{g})$;

$\mathrm{M}_{2}$ : massa do bloco saturado (g).

\subsubsection{Massas específicas}

As massas específicas da amostra seca e saturada foram determinadas utilizando a NBR 9778: 2005 “Argamassas e concretos endurecidos: determinação da absorção de água 
por imersão - índice de vazios e massa específica", e as equações 12 e 13. Essa norma é aplicável para argamassas e concretos endurecidos e foi adaptada para as unidades de alvenaria.

$$
\begin{aligned}
& \gamma_{\text {espec sec } a .}=\frac{M_{3}}{\left(M_{2}-M_{4}\right) / \rho_{a}} \\
& \gamma_{\text {espec sat. }}=\frac{M_{2}}{\left(M_{2}-M_{4}\right) / \rho_{a}}
\end{aligned}
$$

Na qual:

$\gamma_{\text {espec seca: }}$ massa específica seca dos blocos $\left(\mathrm{g} / \mathrm{cm}^{3}\right)$;

$\gamma_{\text {espec sat }}:$ massa específica saturada dos blocos $\left(\mathrm{g} / \mathrm{cm}^{3}\right)$;

$\mathrm{M}_{3}$ : massa do bloco seco ao ar (g);

$\mathrm{M}_{2}$ : massa do bloco saturado (g);

$\mathrm{M}_{4}$ : massa aparente do bloco $(\mathrm{g})$;

$\rho_{\mathrm{a}}$ : massa específica da água $\left(\mathrm{g} / \mathrm{cm}^{3}\right)$.

\subsection{Argamassa de assentamento}

A Tabela 4.8 apresenta a resistência à compressão esperada para diferentes traços de argamassas em volume, correspondente à proporção em cimento, cal e areia, segundo a norma britânica BS 5628 - 1: 1992. Os traços mais comuns usados em obras de alvenaria no Brasil são (ii) e (iii) para argamassa de média e baixa resistência, respetivamente.

Tabela 4.8 - Resistência à compressão e traço em volume da argamassa (Fonte: BS 5628 - 1, 1992).

\begin{tabular}{cccc}
\hline \multirow{2}{*}{ Tipo Traço em Volume } & \multicolumn{2}{c}{ Resistência } \\
\cline { 3 - 4 } & & Laborat. & Situ \\
\hline i & $1: 0$ à $1 / 4: 3$ & $16 \mathrm{MPa}$ & $11 \mathrm{Mpa}$ \\
ii & $1: 1 / 2: 4$ à 4.5 & $6,5 \mathrm{MPa}$ & $4,5 \mathrm{MPa}$ \\
iii & $1: 1: 5$ à 6 & $3,6 \mathrm{MPa}$ & $2,5 \mathrm{MPa}$ \\
iv & $1: 2: 8$ à 9 & $1,5 \mathrm{MPa}$ & $1,0 \mathrm{MPa}$ \\
\hline
\end{tabular}

Segundo Mohamad (1998), deve existir uma compatibilidade entre a resistência da argamassa e a resistência do bloco. O referido autor recomenda que a resistência à compressão da argamassa varie entre 0,7 e 1 da resistência à compressão do bloco na área bruta. Como o objetivo da pesquisa é fabricar blocos com três resistências características diferentes, foi feito um estudo piloto avaliando a argamassa de baixa resistência do tipo (iii) que corresponderia aos blocos com resistência característica de $4 \mathrm{MPa}$ (traço 1:15) e a argamassa de média resistência do tipo (ii) para as unidades com resistência característica 8 e 
12 Mpa (traço 1:10 e 1:6, respectivamente). Outra análise foi feita variando a relação água/cimento da argamassa tipo (ii) para se obtiver diferentes resistências e assim poder escolher uma menos resistente adequada para a resistência característica dos blocos de $8 \mathrm{MPa}$ e outra mais resistente apropriada para os elementos com as unidades de $12 \mathrm{MPa}$.

Ainda para a produção das argamassas, foi utilizado o cimento CPII-Z-32 da marca Itaú e cal hidratada classe CH-II, também da marca Itaú, fabricados de acordo com a NBR 11578: 1997 “Cimento Portland composto - Especificação” e a NBR 7175: 2003 "Cal hidratada para argamassas - Requisitos", respectivamente. O agregado miúdo usado foi areia fina proveniente do Rio Mogi-Guaçu, da cidade de São Carlos, no estado de São Paulo.

Para garantir a qualidade e manter as características das argamassas semelhantes em diferentes betonadas, uma vez determinadas as massas unitárias do cimento, cal e areia, os traços em volume foram convertidos para proporções em massa. No preparo das argamassas, tanto no estudo piloto como na fabricação de prismas e paredes, utilizou-se um misturador mecânico com eixo vertical, conforme recomenda a NBR 15961-2:2011 “Alvenaria estrutural - Blocos de concreto - Execução e controle de obras" obedecendo a seguinte ordem de colocação dos materiais: adição do cimento e areia, mistura dos materiais e adição de $50 \%$ da água, adição gradual e mistura da cal e a colocação do restante de água. A consistência das argamassas foi determinada conforme a NBR 13276: 2005 “Argamassa para assentamento e revestimento de paredes e tetos - Preparo da mistura e determinação do índice de consistência” e o ensaio pode ser visualizado na Figura 4.26.

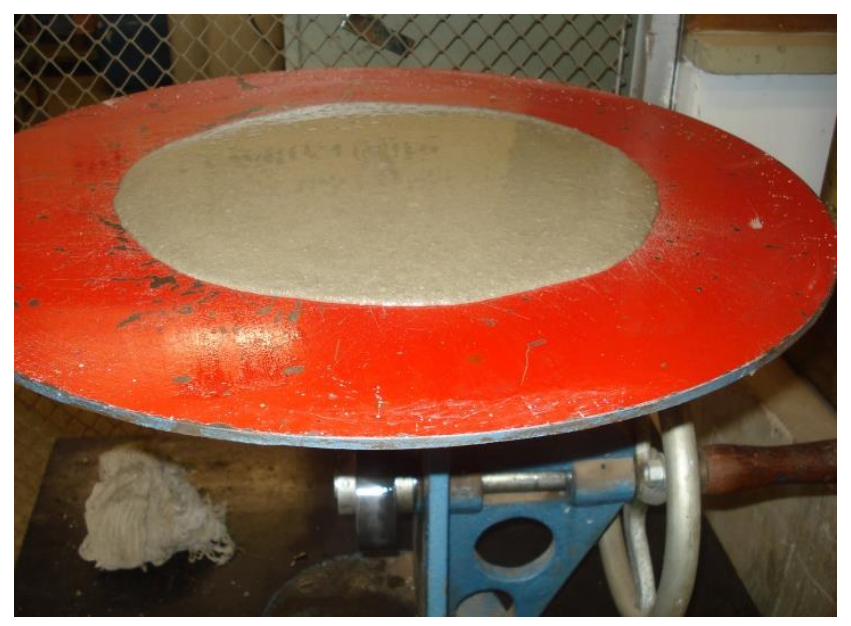

Figura 4.26 - Ensaio de consistência da argamassa (Fonte: autor)

Após o preparo da argamassa, tanto no estudo piloto como na fabricação de prismas e paredes, foram moldados corpos de prova cúbicos de 4 x 4 x $4 \mathrm{~cm}$ em moldes metálicos para a determinação da resistência à compressão. A moldagem dos corpos foi feita com adensamento 
manual, em duas camadas, com 30 golpes do soquete (Figura 4.27). O total de amostras no estudo piloto foi 24, seis para avaliar a argamassa do tipo (iii) e seis para cada relação água/cimento que foram variadas na argamassa do tipo (ii) (três variações). Na fabricação dos prismas e das pequenas paredes o número de amostra foi 48 , sendo seis para cada série de blocos, constituindo oito séries. As argamassas foram retiradas das fôrmas após 24 horas, identificadas e levadas à câmara úmida até o instante do ensaio de resistência à compressão.

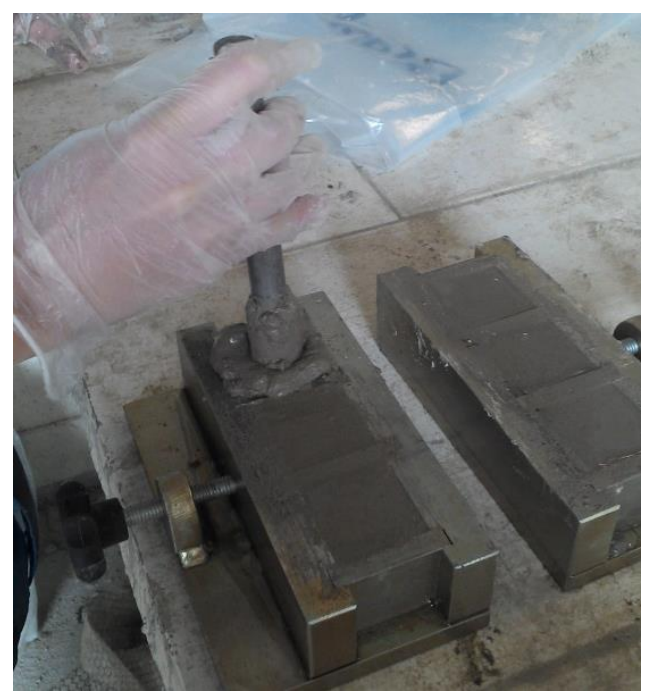

Figura 4.27 - Moldagem da argamassa em corpos de prova cúbicos (Fonte: autor)

\subsubsection{Ensaio de resistência à compressão da argamassa de assentamento}

O ensaio de resistência à compressão das argamassas seguiram a idade dos ensaios das peças de alvenaria correspondentes, que foi sempre a partir dos 28 dias. No estudo piloto a idade do ensaio foi 28 dias também. O ensaio cumpriu com as prescrições do Anexo D da NBR 15961-2: 2011 e foi realizado na máquina computadorizada da marca ELE e Modelo Autotest 2000, com capacidade de $2000 \mathrm{kN}$ e velocidade de imposição de carregamento de $500 \pm 50 \mathrm{~N} / \mathrm{s}$ até a ruptura do material. Os corpos de prova foram posicionados de modo que a face rasada não ficou em contato com os pratos da máquina como mostra a Figura 4.28. 


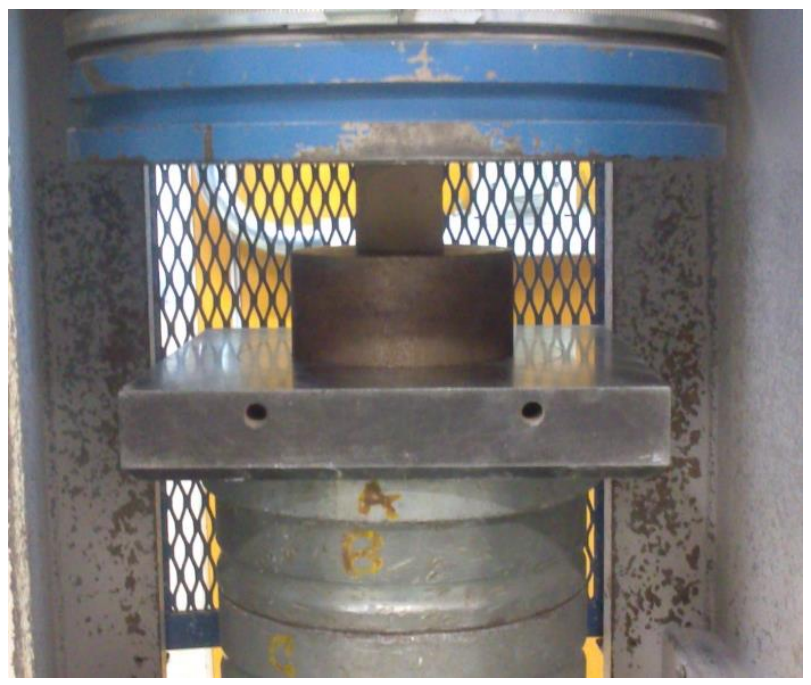

Figura 4.28 - Ensaio de resistência a compressão da argamassa (Fonte: autor)

A Tabela 4.9 apresenta o resumo dos valores médios de resistência à compressão e índice de consistência das argamassas correspondentes ao estudo piloto.

Tabela 4.9 - Características das argamassas utilizadas no ensaio piloto (Fonte: autor)

\begin{tabular}{cccccc}
\hline Denominação & $\begin{array}{c}\text { Traço em volume } \\
\text { (cimento:cal:areia) }\end{array}$ & $\begin{array}{c}\text { Tipo de } \\
\text { argamassa }\end{array}$ & $\begin{array}{c}\text { Índice de } \\
\text { consistência } \\
\text { (mm) }\end{array}$ & $\begin{array}{c}\text { Relação } \\
\text { água/cimento }\end{array}$ & $\begin{array}{c}\text { Resistência } \\
\text { média (fa) } \\
\text { (MPa) }\end{array}$ \\
\hline A1 & $1: 1: 6$ & (iii) & 280 & 1,60 & 3,61 \\
\hline B 1 & & & 243 & 1,35 & 6,45 \\
B 2 & $1: 0.5: 5$ & (ii) & 221 & 1,25 & 7,28 \\
B 3 & & & 119 & 1,15 & 8,13 \\
\hline
\end{tabular}

A argamassa A1 foi escolhida para a fabricação de prismas e pequenas paredes correspondentes aos blocos do traço pobre $\left(f_{b k}=4 \mathrm{MPa}\right)$. Já a argamassa do tipo (ii) apresentou três resistências em função da variação da relação água/cimento. Para os elementos de alvenaria correspondente aos blocos do traço médio $\left(\mathrm{f}_{\mathrm{bk}}=8 \mathrm{MPa}\right)$ foi escolhida a argamassa B1 com resistência média de 6,45 MPa. A argamassa B3 com resistência média de 8,13 MPa seria a certa para os prismas e as paredes com as unidades com base na resistência característica de $12 \mathrm{MPa}$ mas apresentou uma consistência baixa, ficando a mistura seca e pouco fluída, o que impossibilitaria ao pedreiro a fabricação dos elementos de alvenaria. Dessa maneira a argamassa escolhida para os blocos de maior resistência foi a B2 com resistência média de 7,28 MPa. 


\subsection{Ensaio de resistência à compressão dos blocos, prismas e pequenas paredes}

Para avaliar o uso de resíduos e fibras nos blocos de concreto e cumprir com o objetivo proposto na pesquisa foi necessário realizar o ensaio de resistência à compressão das unidades, prismas e pequenas paredes.

\subsubsection{Ensaio de resistência à compressão dos blocos}

A NBR 12118: 2013 prescreve o método de determinação da resistência à compressão em blocos vazados de concreto simples para alvenaria estrutural. A caracterização dos blocos foi feita em termos de resistência média $\left(f_{b m}\right)$ e de resistência característica $\left(f_{b k}\right)$. A norma especifica que para a realização do ensaio é necessário uma prensa equipada com dois pratos de aço que são usados como apoio. Por esse motivo foi utilizada a máquina computadorizada marca ELE e Modelo Autotest 2000, com capacidade de 2000 kN e velocidade de imposição de carregamento 2,03 kN/s. Os blocos foram ensaiados secos ao ar como mostra a Figura 4.29.

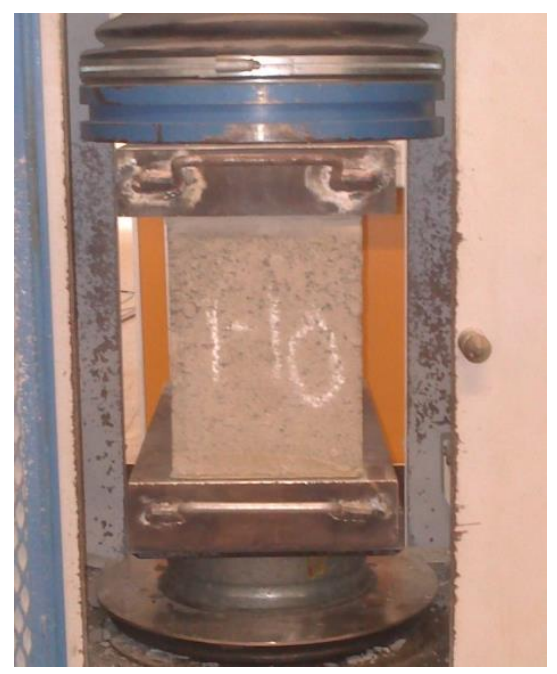

Figura 4.29 - Ensaio de resistência a compressão do bloco (Fonte: autor)

Realizou-se o ensaio de resistência à compressão em 12 blocos para cada série, totalizando 96 blocos (oito séries, ver Tabela 6.1). A carga foi aplicada na direção do esforço que o bloco deve suportar em serviço. $\mathrm{O}$ alinhamento do bloco na prensa é um item de extrema importância, sendo o seu centro de gravidade coincidente com o alinhamento do centro de carga dos pratos de aço usados como apoio na prensa. Para a regularização das faces dos blocos foi feito o capeamento com pasta de cimento. Esse procedimento se encontra detalhado no item 4.10 .

Antes do ensaio foi determinada a área bruta dos blocos. Ela deve ser calculada como o valor médio de pelo menos três determinações em pontos distintos: um em cada extremidade 
e um no meio, sem desconto das áreas dos furos. A resistência de cada bloco, expressa em $\mathrm{MPa}$, é obtida dividindo a carga de ruptura pela área bruta.

\subsubsection{Ensaio de resistência à compressão dos prismas}

A NBR 15961 - 1: 2011 adota prismas de dois blocos como os elementos que podem ser utilizados para estimar resistência à compressão de paredes de alvenaria estrutural de blocos vazados de concreto. Assim, o estudo de prismas compostos por unidades com adição de materiais alternativos permitiu esclarecer se essa adição influencia na resistência à compressão e no módulo de deformação desses elementos e, por consequência, nas características da própria alvenaria. Isso foi feito através da comparação com os resultados obtidos para prismas de referência.

Foram ensaiados um total de 80 prismas (10 para cada série) com dimensões totais de $14 \mathrm{~cm}$ x $19 \mathrm{~cm}$ x $39 \mathrm{~cm}$ (espessura x largura x altura), sendo $1 \mathrm{~cm}$ de espessura a junta de argamassa.

Os prismas foram moldados diretamente no piso do laboratório sempre controlando o nível, o prumo e a espessura da junta. A produção foi iniciada pelo nivelamento do bloco inferior com auxílio de nível de bolha e posterior disposição dos cordões de argamassa nas paredes transversais e longitudinais como se visualiza na Figura 4.30. A cura foi feita no ambiente do laboratório até a data de ensaio aos 28 dias.

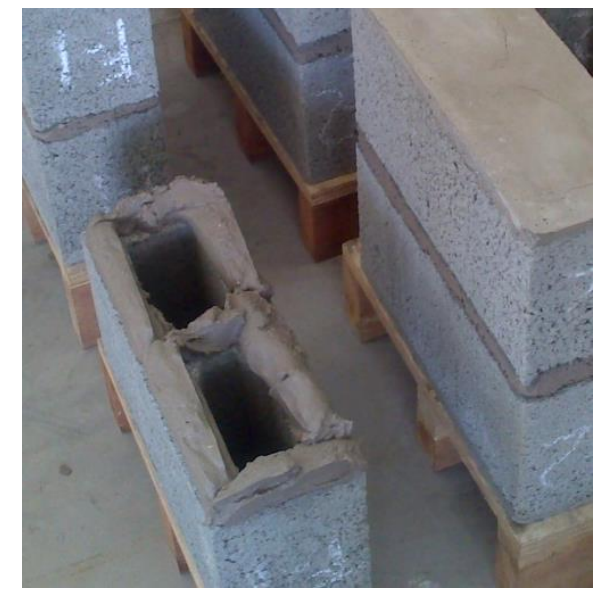

Figura 4.30 - Disposição dos cordões de argamassa nos prismas (Fonte: autor)

Os elementos foram ensaiados na máquina servo-controlada INSTRON modelo 8506 acoplada a um sistema de aquisição de dado (SYSTEM 5000) conforme recomendação da NBR 15961 - 2: 2011. O carregamento foi aplicado com controle de deslocamentos a uma velocidade de $0,02 \mathrm{~mm} / \mathrm{s}$. Na parte superior dos corpos de prova foi disposta uma placa de aço 
de espessura de $35 \mathrm{~mm}$ para distribuição uniforme do carregamento como mostra a Figura 4.31 .

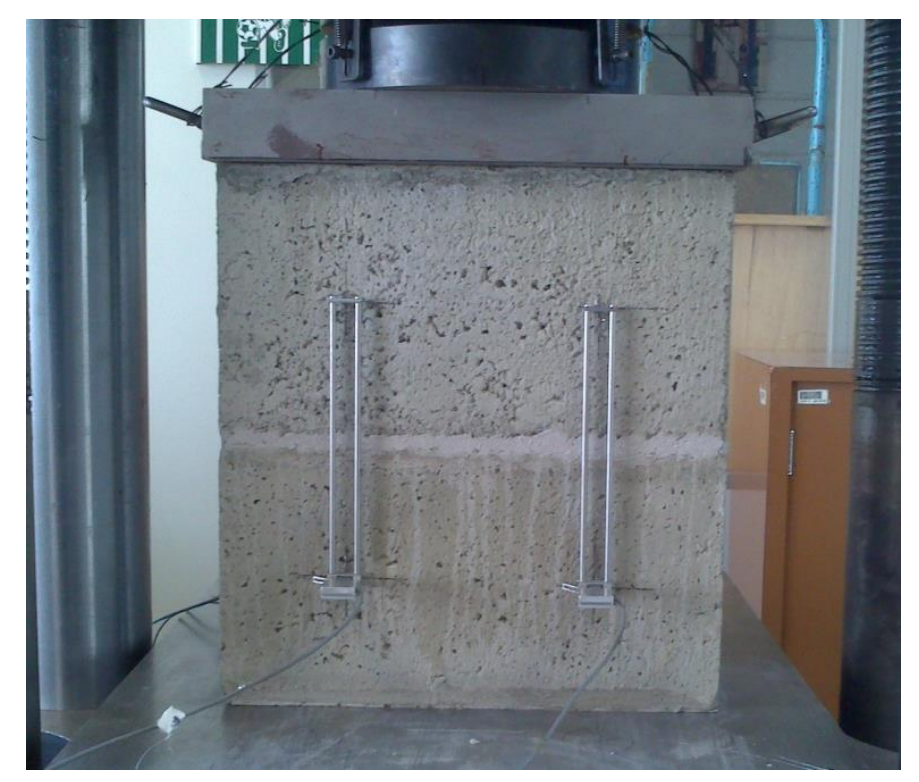

Figura 4.31 - Ensaio de resistência à compressão dos prismas (Fonte: autor)

\subsubsection{Ensaio de resistência à compressão das pequenas paredes}

As pequenas paredes também são elementos que podem ser utilizados como estimativa da resistência de paredes de alvenaria. A NBR 15961 - 1: 2011 menciona as pequenas paredes, inclusive indicando que as resistências das paredes são iguais a $85 \%$ da sua resistência. Além disso, a NBR 15812-2: 2010 “Alvenaria estrutural - blocos cerâmicos: execução e controle de obras" traz em seu anexo B todas as recomendações necessárias à montagem do corpo de prova e ao ensaio.

Foram construídas 5 pequenas paredes com os blocos de cada série totalizando 40 elementos a serem ensaiados. O número de fiadas foi de cinco, constituindo um total de oito blocos e quatro meio-blocos por elemento. As dimensões totais foram $14 \mathrm{~cm}$ x $79 \mathrm{~cm}$ x $99 \mathrm{~cm}$ (espessura x largura x altura), com $1 \mathrm{~cm}$ de espessura para as juntas da argamassa vertical e horizontal.

Os elementos foram construídos sobre uma base de madeira possibilitando seu futuro transporte. A construção foi feita por um pedreiro experiente, iniciando pelo nivelamento de dois blocos inferiores com auxílio do nível de bolha. Posteriormente foi feita a disposição dos cordões de argamassa nas paredes transversais e longitudinais e na junta vertical. Em seguida, foram assentadas as fiadas superiores verificando-se o nível, o prumo e a planeza (Figura 4.32). A cura foi feita no ambiente do laboratório até a data de ensaio. 


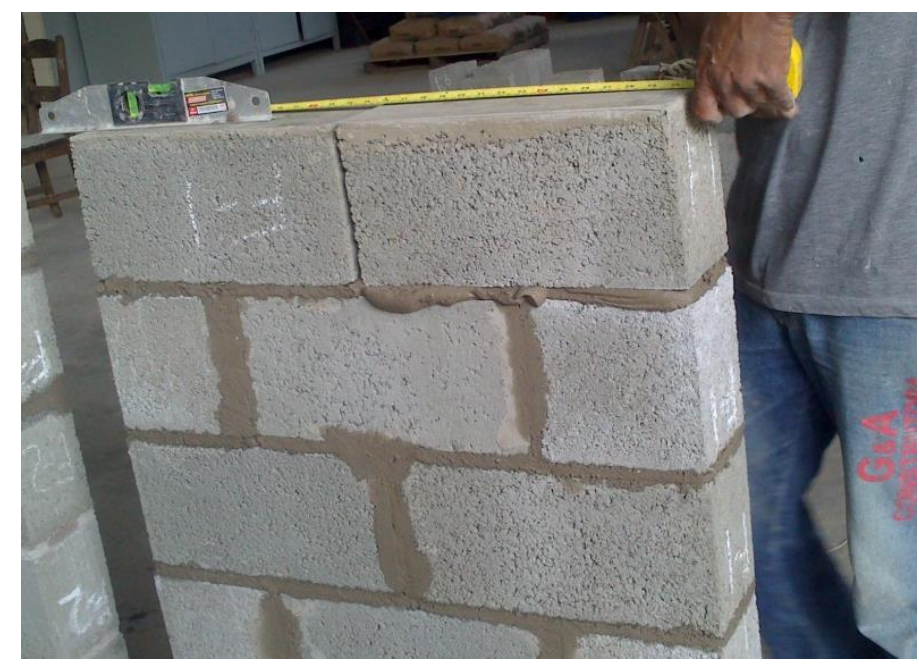

Figura 4.32 - Assentamento das fiadas superiores verificando-se o nível, o prumo e a planeza (Fonte: autor)

Os ensaios foram realizados na máquina servo-controlada INSTRON, modelo 8506 acoplada a um sistema de aquisição de dado (SYSTEM 5000). O carregamento foi aplicado com controle de deslocamentos a uma velocidade de $0,01 \mathrm{~mm} / \mathrm{s}$. Um perfil de aço colocado no topo da parede garantiu a distribuição uniforme do carregamento sobre o corpo de prova como mostra a Figura 4.33.

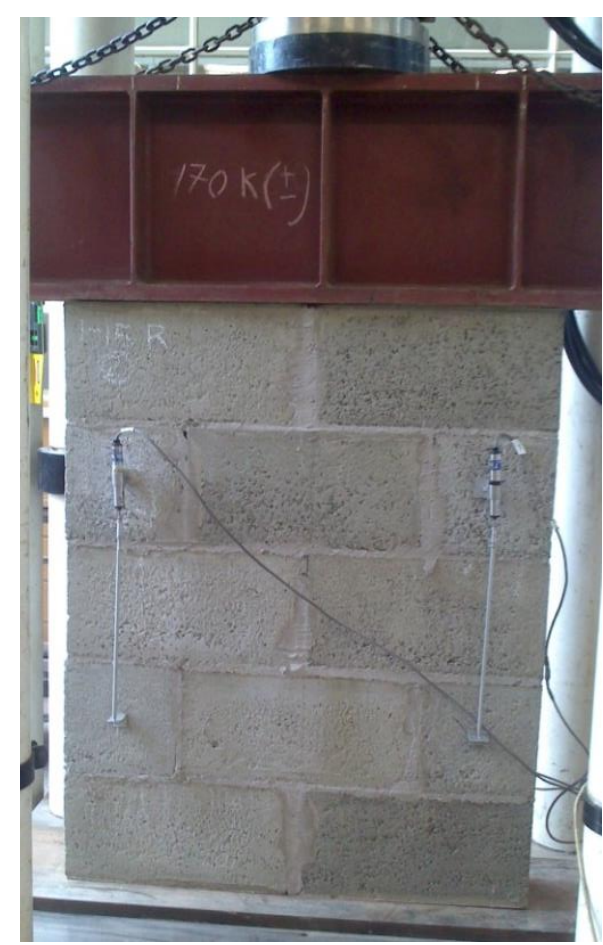

Figura 4.33 - Ensaio de resistência à compressão das pequenas paredes (Fonte: autor) 


\subsection{Capeamento dos blocos}

O capeamento é uma fina camada de um determinado material disposta na superfície dos elementos. É utilizado para reduzir os efeitos das irregularidades no topo e na base a fim de proporcionar uma distribuição mais uniforme das tensões e minimizando as concentrações. Nos ensaios de compressão axial, o capeamento fica em contato direto com as placas de ensaio.

Segundo NBR 12118: 2013, a regularização das faces dos blocos de concreto deve ser feita com um material que ofereça resistência no mínimo igual à do bloco a ser ensaiado. $\mathrm{O}$ capeamento pode ser realizado com pastas ou argamassas formando uma fina camada e não excedendo os $3 \mathrm{~mm}$ de espessura.

A argamassa foi dosada na proporção 1:1 (cimento CPV ARI : areia fina) com quantidade de água suficiente para a consistência necessária. Corpos de prova $(5 \times 10 \mathrm{~cm})$ executados com a argamassa obtiveram resistência à compressão de $60 \mathrm{MPa}$ aos 28 dias, valor bem acima da resistência dos blocos escolhidos para o trabalho experimental.

Para execução do capeamento seguiram-se as seguintes etapas:

$1^{\text {a }}$ - Nivelamento de uma chapa metálica colocada em uma mesa metálica;

$2^{\mathrm{a}}$ - Distribuição de óleo na superfície da chapa; distribuição da pasta com espessura de $3 \pm 1 \mathrm{~mm}$ e assentamento do bloco;

$3^{\mathrm{a}}$ - Nivelamento da superfície do bloco com o auxílio do nível de bolha;

$4^{\mathrm{a}}$ - Retirada do excesso de massa das laterais do bloco;

$6^{\mathrm{a}}$ - Desforma dos blocos após 12 horas.

A Figura 4.34 mostra algumas das etapas desse processo.

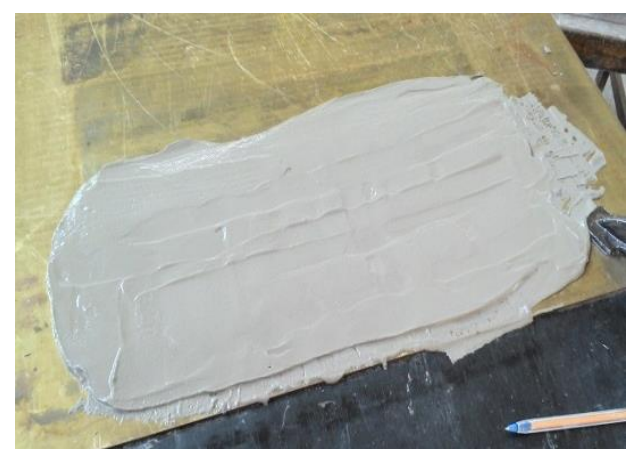

(a)

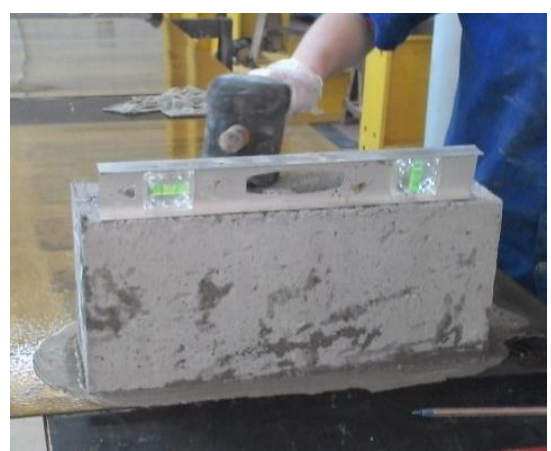

(b) 


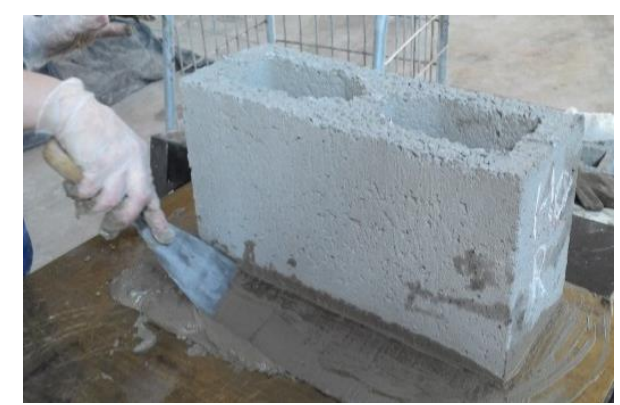

(c)

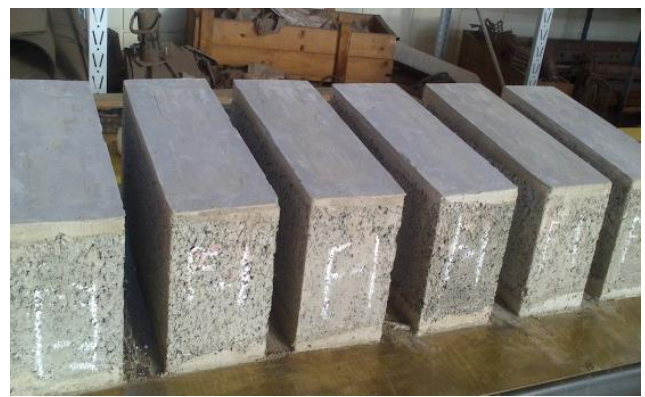

(d)

Figura 4.34 - Capeamento dos blocos: (a) distribuição da pasta com espessura de $3 \pm 1 \mathrm{~mm}$, (b) nivelamento do bloco com o auxílio do nível de bolha, (c) retirada do excesso de massa das laterais do bloco e (d) desforma dos blocos após 12 horas (Fonte: autor).

\subsection{Módulo de deformação de prismas e pequenas paredes}

O módulo de deformação foi calculado para os prismas e as pequenas paredes de acordo com as prescrições do ACI 530: 2011 "Building code requirements for masonry structures and specification". Segundo esse texto, o módulo é dado pela inclinação da reta secante no diagrama tensão versus deformação entre 5\% e 33\% da tensão de ruptura.

As curvas de tensão versus deformação foram traçadas tomando-se a tensão na área bruta e calculando-se a deformação específica, dividindo-se a média dos deslocamentos pelo comprimento da haste dos clip-gauges e dos transdutores.

\subsubsection{Módulo de deformação dos prismas}

A instrumentação foi constituída de quatro clip-gauges, de base igual a $200 \mathrm{~mm}$, posicionados simetricamente nas faces dos prismas. A velocidade de imposição de deslocamento foi de $0,02 \mathrm{~mm} / \mathrm{s}$ e os registros foram feitos a cada 1,5 segundos. As leituras e o armazenamento de dados foram realizados pelo sistema de aquisição SYSTEM 5000.

A Figura 4.35 ilustra a posição da instrumentação onde foram colocados os clip-gauges.
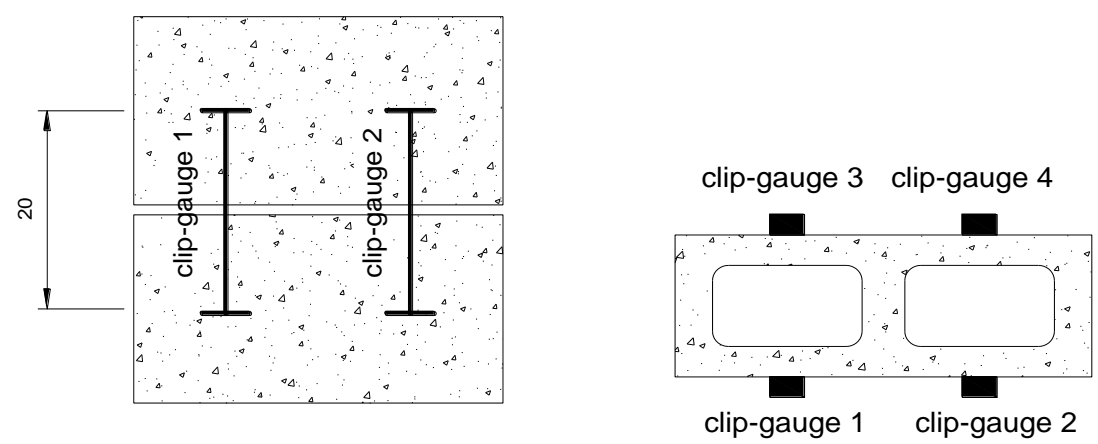

Figura 4.35 - Vista frontal e em planta da localização dos clip-gauges nos prismas (Fonte: autor). 
Foram realizados ciclos de carga e descarga com o objetivo de acomodar e diminuir prováveis excentricidades do corpo de prova. A carga aplicada para a acomodação foi igual a $10 \%$ da carga de ruptura prevista para os prismas. Assim, os corpos de prova foram submetidos a essa carga e descarregados totalmente, sendo essa operação repetida novamente. Em seguida, os prismas foram submetidos à carregamentos até alcançarem a ruptura, obtendose a sua resistência à compressão.

\subsubsection{Módulo de deformação das pequenas paredes}

A instrumentação foi constituída por transdutores de deslocamento conhecidos como LVDT de base de medida igual a $20 \mathrm{~mm}$ e resolução de $0,001 \mathrm{~mm}$. A velocidade de imposição de deslocamento foi de $0,01 \mathrm{~mm} / \mathrm{s}$ e os registros foram feitos a cada 1,5 segundos. As leituras e o armazenamento de dados foram realizados pelo sistema de aquisição SYSTEM 5000.

A instrumentação para a determinação dos deslocamentos foi colocada exatamente nas regiões centrais das cavidades das unidades, como ilustra o esquema da Figura 4.36.
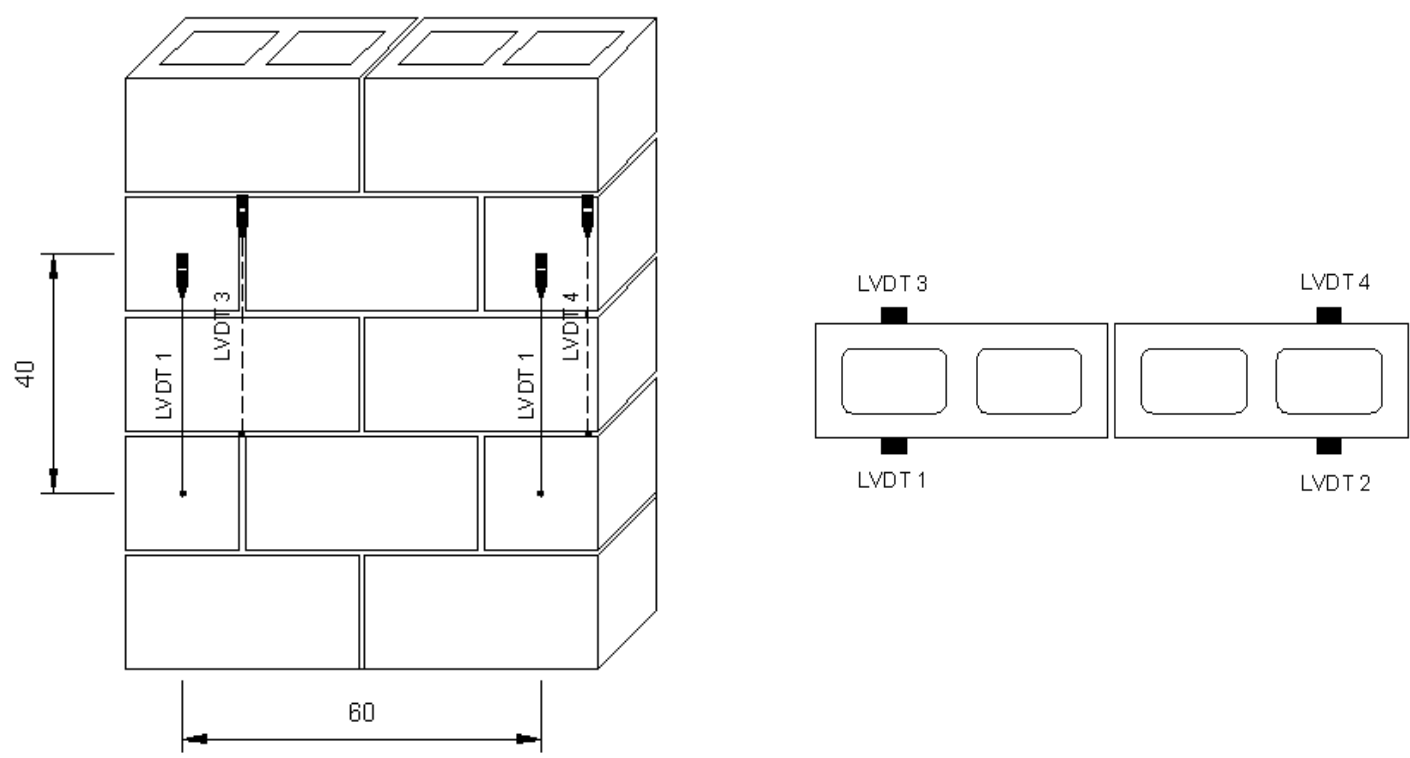

Figura 4.36 - Vista frontal e em planta da localização dos transdutores de deslocamento nas pequenas paredes (Fonte: autor).

Foram realizadas etapas de carga e descarga com o mesmo objetivo explicitado anteriormente. A carga aplicada para a acomodação foi igual a $10 \%$ da carga de ruptura prevista para as pequenas paredes. Assim, os corpos de prova foram submetidos a essa carga e descarregados totalmente, sendo essa operação repetida novamente. Em seguida, as pequenas 
paredes foram submetidas à carregamentos até alcançarem a ruptura, obtendo-se a sua resistência à compressão.

\subsection{Aumento e avaliação da durabilidade da fibra de sisal no concreto}

Como foi descrito no Capítulo 2, a baixa durabilidade do sisal no concreto é dado pela petrificação da fibra devido à formação do hidróxido de cálcio $(\mathrm{CH})$ nos seus vazios. Existem duas vertentes para atenuar os efeitos da interação fibra-matriz e assim aumentar a durabilidade e o desempenho do sisal no concreto. A primeira consiste em modificar a composição da matriz a fim de reduzir o composto alcalino $\mathrm{CH}$ e a segunda em modificar a superfície das fibras com tratamentos químicos ou físicos. Nesta pesquisa optou-se pela primeira variante, ou seja, tornar a matriz menos alcalina com um $\mathrm{pH}$ baixo e obter menor formação do $\mathrm{CH}$. Dessa forma, dois tipos de concretos reforçados com sisal foram produzidos, o primeiro foi feito com o cimento Portland CPV ARI RS, escolhido para a fabricação dos blocos; e o segundo com o cimento CP III 40 RS e adição de $10 \%$ de sílica com relação ao volume do cimento. Esses cimentos apresentam características muito distintas em termos de porcentual de clínquer presente. O cimento CP V-ARI constitui-se de no mínimo $95 \%$ de clínquer. Já o CP III-40-RS possui grande parte do clínquer substituído por escória de alto forno (35 a $70 \%$ ), tornando-o menos alcalino e, por conseguinte, menos agressivo às fibras vegetais.

Os materiais pozolânicos, como são neste caso a sílica e a escória de alto forno presente no CP III, causam na matriz cimentícia um efeito químico chamado reação pozolânica que altera o processo de hidratação. As partículas das adições pozolânicos reagem com as partículas de $\mathrm{CH}$ que durante a hidratação do cimento se formaram preferencialmente na região mais porosa da zona de interface. O produto dessa reação é uma quantidade adicional de silicato de cálcio hidratado $(\mathrm{C}-\mathrm{S}-\mathrm{H})$. Com isto substitui-se um produto mais frágil e solúvel, e que favorece a microfissuração devido ao seu formato e orientação como é $\mathrm{CH}$, por um produto mais resistente como é C-S-H. A adição desses materiais pozolânicos melhora não só a interface da pasta com a fibra, mas, também a pasta como um todo, diminuindo a dimensão e quantidade dos poros. O resultado é um concreto mais resistente, com menor porosidade, menos alcalino, menos agressivo e com menor teor de $\mathrm{CH}$.

Dessa forma, a adição de sílica ativa e o uso de cimentos com baixa alcalinidade podem conferir melhora do desempenho do sisal a longo prazo. Já a presença da fibra em meios agressivos, como é o caso de matrizes à base de cimento com alto teor de clínquer, pode levar à deterioração e à perda de ductilidade do sisal. Para avaliar o desempenho do sisal, os blocos 
reforçados com fibras de comprimento $20 \mathrm{~mm}$ e teor $1 \%$ com relação ao volume do concreto foram expostos a ciclos de umedecimento e secagem por um período de 9 meses. Cumprido esse prazo, foi realizado o ensaio de resistência à tração indireta dos blocos e o ensaio de resistência à compressão dos blocos, prismas e pequenas paredes. Adicionalmente, fragmentos de blocos foram analisados em microscópico eletrônico de varredura (MEV) para adquirir microimagens das fibras imersas na matriz e também foi realizada a análise por EDS para obter a composição química na superfície da fibra e na zona de transição fibra-pasta de cimento.

O cimento CP III 40 RS (cimento Portland de alto forno resistente a sulfatos) atende à norma NBR 5735: 1991 "Cimento Portland de alto-forno". O CP III é comercializado, também, pelo Grupo Holcim, com a denominação comercial ULTRA FORTE - CP III 40 RS. A sílica ativa (Elkem Microsilica ${ }^{\circledR}$ 920D), proveniente da fabricação de ligas de ferrosilício, possui massa específica de $2,23 \mathrm{~g} / \mathrm{cm}^{3}$. O fabricante, Elkem Materials South America Ltda., indica ainda área superficial específica (BET) mínima de $150000 \mathrm{~cm}^{2} / \mathrm{g}$ da sílica dispersa, teor de sílica amorfa de 85 a $99 \%$, carbono de 1 a $6 \%$ e o restante composto de óxidos de ferro, alumínio e magnésio. O produto apresenta retenção inferior a $10 \%$ na peneira \# 325 (abertura $45 \mu \mathrm{m}$ ).

A resistência à tração indireta do bloco foi determinada de acordo com o procedimento da norma americana ASTM C1006-7: 2010 "Standard Test Method for Splitting Tensile Strength of Masonry Units", pois não existe nenhuma norma brasileira similar. O procedimento consistiu em dispor duas barras cilíndricas de $16 \mathrm{~cm}$ de comprimento e $2 \mathrm{~cm}$ de diâmetro na face superior e inferior da unidade e aplicar uma força de compressão que resultará no surgimento de tensões de tração ao longo da altura da unidade. As barras foram colocadas na região central de um dos furos onde há apenas paredes ortogonais ao carregamento (Figura 4.37). Isso se deve a que testes preliminares indicaram que ao aplicar o carregamento no centro do bloco ocorria ruptura por esmagamento e não por tração indireta. Acredita-se que isso tenha ocorrido devido à presença de paredes internas na mesma direção do carregamento. O carregamento foi aplicado com controle de deslocamentos a uma velocidade de $0,001 \mathrm{~mm} / \mathrm{s}$. 


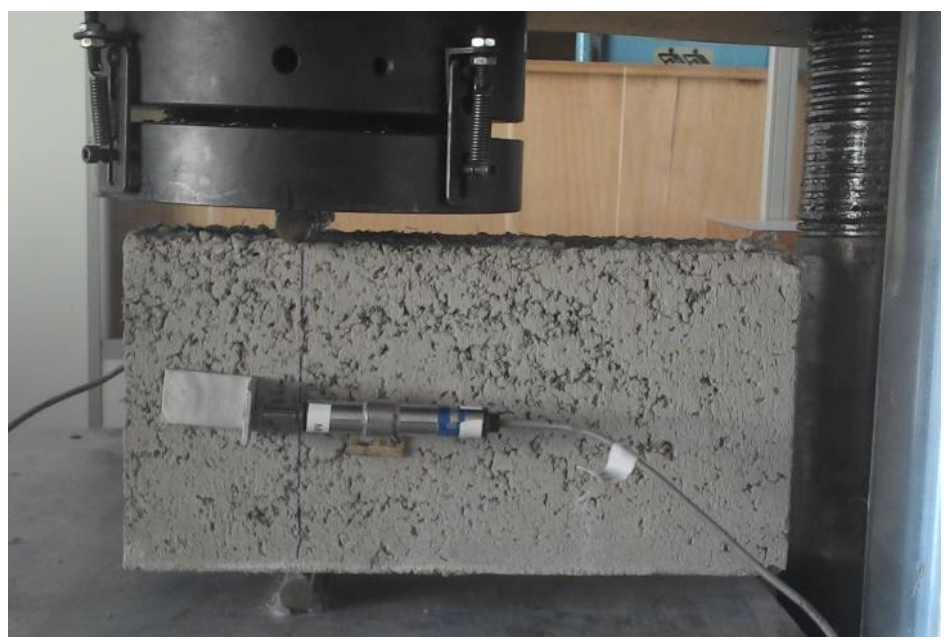

Figura 4.37 - Ensaio de resistência à tração indireta dos blocos (Fonte: autor)

A equação 19 foi utilizada para determinação da tração indireta dos blocos.

$\mathrm{f}_{\mathrm{tb}, \text { ind }}=\frac{2 \mathrm{~F}}{\pi \cdot \mathrm{l} \cdot \mathrm{h}}$

Em que:

$\mathrm{f}_{\mathrm{tb}, \text { ind }}$ - resistência à tração indireta do bloco, em MPa;

$\mathrm{F}$ - carga aplicada, em N;

l - largura do bloco, em mm;

$\mathrm{h}$ - altura do bloco, em mm.

A resistência à tração indireta das unidades foi calculada considerando a largura líquida (soma das espessuras das paredes ortogonais ao carregamento). 



\section{RESULTADOS E DISCUSSÕES: MATERIAIS E CORPOS DE PROVA}

Este capítulo tem como finalidade apresentar a avaliação de algumas propriedades físicas e químicas do pó residual orgânico e do pó de pedra e a influência desses materiais na substituição de parte da matéria-prima no concreto, como o cimento e a areia. Também foram analisadas as características da fibra de sisal e dos materiais usados na fabricação dos blocos como o cimento e os agregados miúdo e graúdo. Do mesmo modo, são mostrados os ensaios realizados nos corpos de prova que foram fabricados com o objetivo de definir a porcentagem que cause o melhor comportamento no concreto. Para isso, um estudo estatístico foi realizado nos resultados de resistência à compressão do concreto para uma melhor interpretação dos resultados. Uma vez definido o teor ideal de pó de pedra substituindo a areia e o teor ideal de pó orgânico substituindo o cimento em cada um dos traços, foi realizada a fabricação dos blocos estruturais.

\subsection{Caracterização do pó de resíduo orgânico}

Neste item são apresentadas as análises dos resultados da caracterização do pó proveniente do resíduo orgânico.

\subsubsection{Microscopia eletrônica de varredura (MEV)}

Utilizou-se a análise por MEV para serem obtidas microimagens das partículas do pó residual em três amostras, como mostra a Figura 5.1.
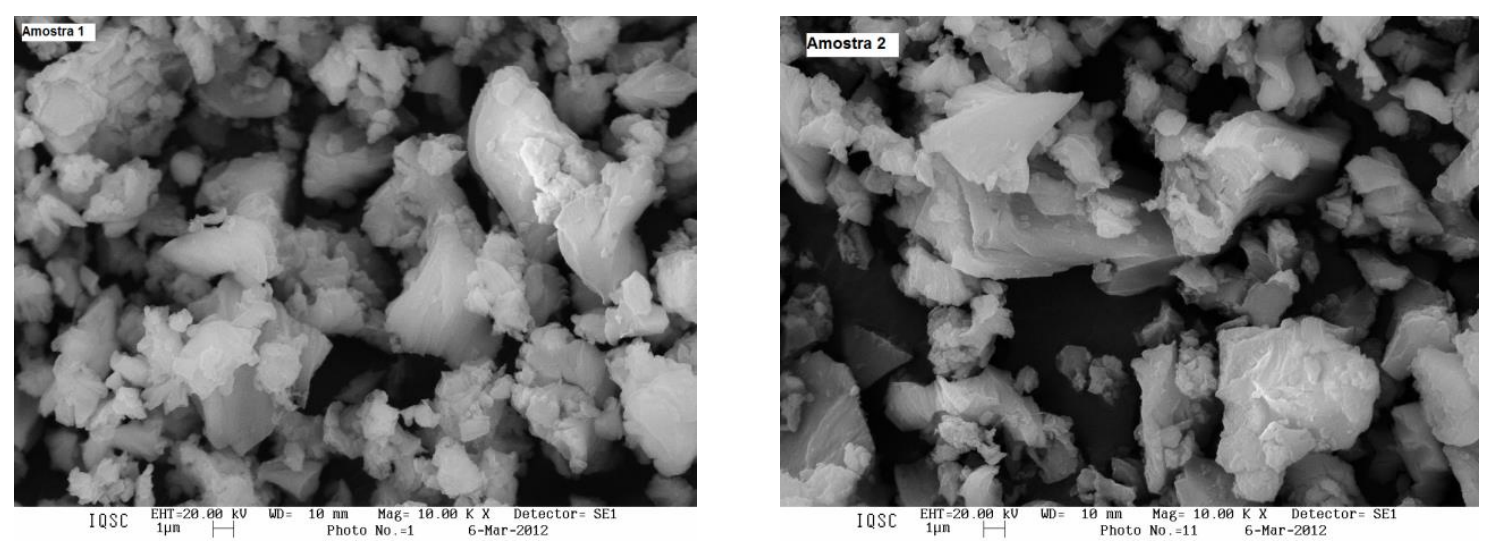


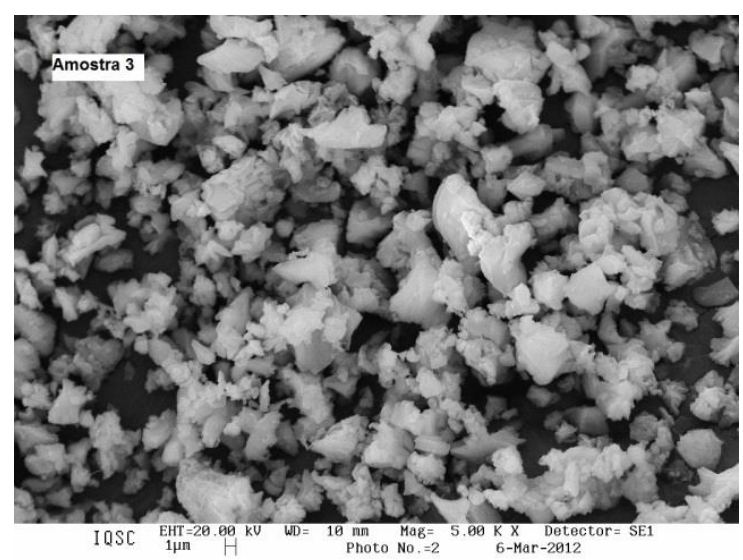

Figura 5.1 - Microimagens das partículas do pó residual orgânico (Fonte: autor)

Nota-se que as partículas do pó residual são formadas por grãos de dimensão e formatos variados. Algumas possuem aspecto circular e outras lamelares, com camadas sobrepostas e com pequenas partículas aderidas à superfície. Com a utilização do programa Image J, foi possível medir a dimensão das partículas do material. A Tabela 5.1 apresenta os valores para algumas amostras.

Tabela 5.1 - Dimensão das partículas do pó residual orgânico (Fonte: autor).

\begin{tabular}{cccc}
\cline { 2 - 4 } & $\begin{array}{c}\text { Amostra 1 } \\
(\boldsymbol{\mu m})\end{array}$ & $\begin{array}{c}\text { Amostra 2 } \\
(\boldsymbol{\mu m})\end{array}$ & $\begin{array}{c}\text { Amostra 3 } \\
(\boldsymbol{\mu m})\end{array}$ \\
\cline { 2 - 4 } & 3,88 & 2,94 & 4,56 \\
& 3,50 & 4,36 & 6,37 \\
& 5,03 & 2,08 & 3,82 \\
& 5,31 & 2,75 & 2,79 \\
& 1,89 & 5,27 & 7,31 \\
& 2,18 & 2,26 & 3,69 \\
& 2,89 & 2,95 & 2,16 \\
& 1,75 & 1,59 & 1,34 \\
& 2,74 & 2,07 & 1,47 \\
& 1,70 & 2,89 & 1,84 \\
& 5,46 & 1,63 & 2,13 \\
& 5,17 & 3,06 & 1,69 \\
& 2,95 & 4,56 & 3,95 \\
\hline Média & $\mathbf{3 , 2 8}$ & $\mathbf{3 , 1 6}$ & $\mathbf{3 , 2 6}$ \\
\hline SD & $\mathbf{1 , 4 6}$ & $\mathbf{1 , 2 2}$ & $\mathbf{1 , 8 3}$ \\
\hline
\end{tabular}

Na Tabela 5.1 podem-se notar dimensões variáveis das partículas do pó residual. Isso pode ser favorável, já que esse material pode atuar como um fíler no concreto, permitindo maior preenchimento dos espaços vazios na matriz cimentícia. 


\subsubsection{Análise química}

Conforme se mencionou na metodologia, a análise química foi feita por meio da espectroscopia de energia dispersiva por raio-X (EDS), que determina quais elementos da tabela periódica estão presentes e em que proporção. A Figura 5.2 ilustra os espectros obtidos de três amostras de pó de resíduo orgânico.

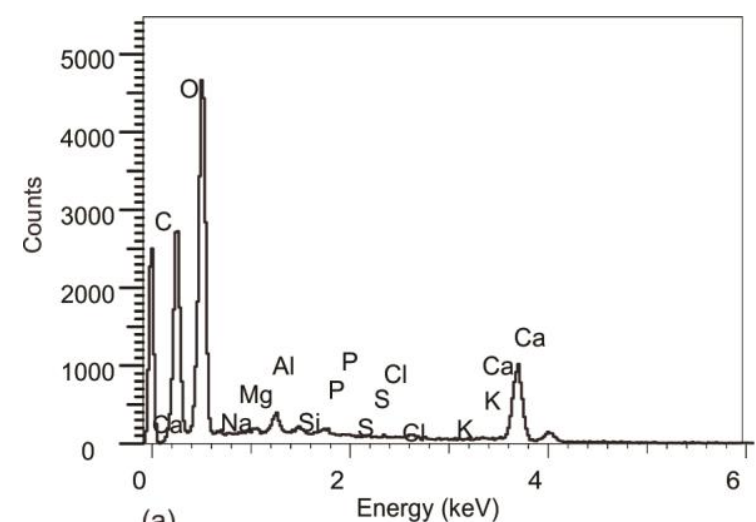

(a)
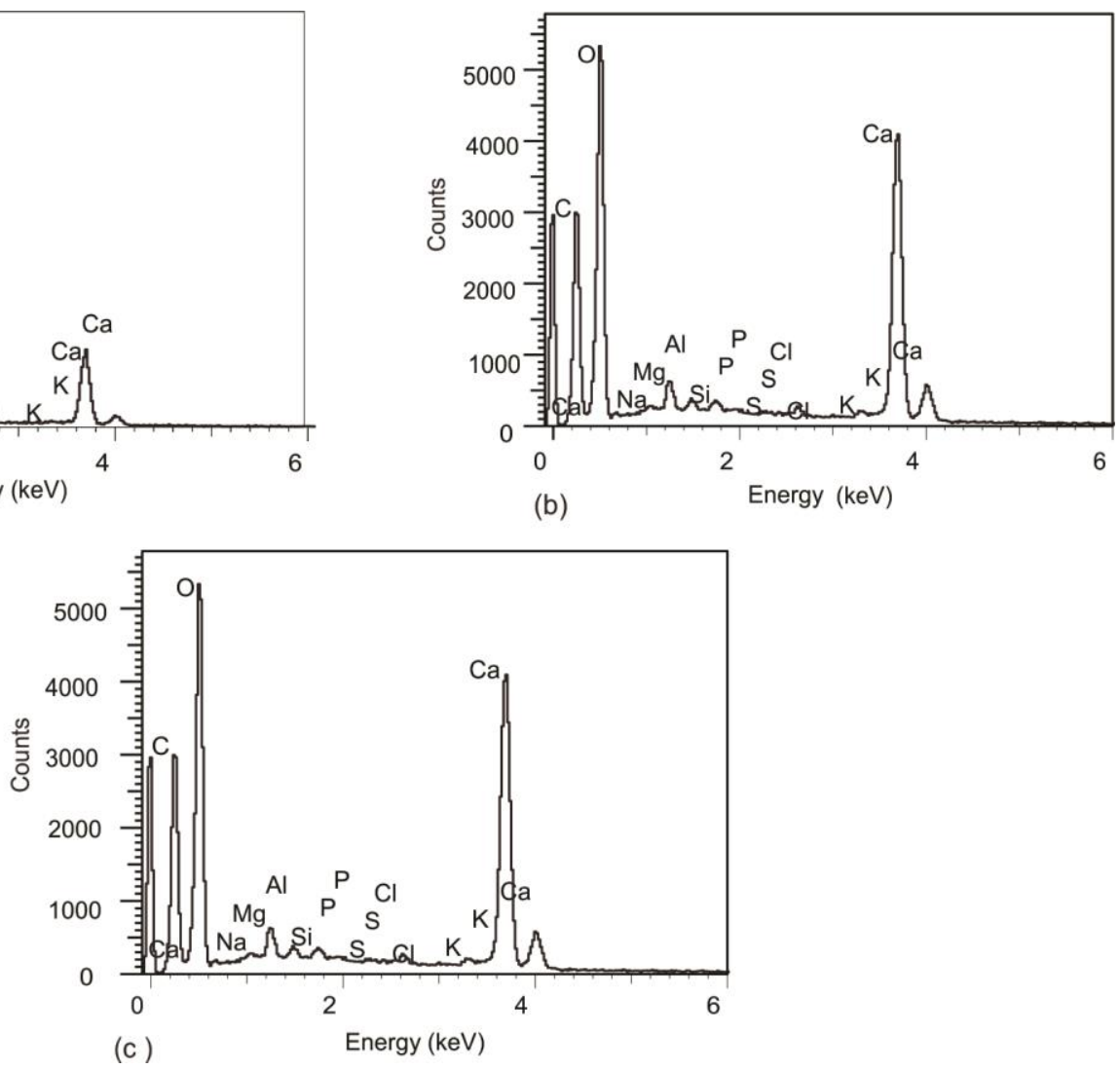

Figura 5.2 - Espectros obtidos por EDS de três amostras de pó de resíduo orgânico (Fonte: autor)

Para uma melhor compreensão dos resultados, a Tabela 5.2 apresenta um resumo com a média dos valores da composição química das três amostras do pó de resíduo orgânico.

Tabela 5.2 - Composição química das três amostras do pó de resíduo orgânico (Fonte: autor)

\begin{tabular}{ccc}
\hline $\begin{array}{c}\text { Tipo de } \\
\text { elemento }\end{array}$ & $\begin{array}{c}\text { \% Elemento } \\
\text { (em massa) }\end{array}$ & \% Átomos \\
\hline $\mathrm{C}$ & 21,37 & 29,50 \\
$\mathrm{O}$ & 58,19 & 61,00 \\
$\mathrm{Na}$ & 0,28 & 0,21 \\
$\mathrm{Mg}$ & 1,19 & 0,83 \\
$\mathrm{Al}$ & 0,21 & 0,13 \\
$\mathrm{Si}$ & 0,32 & 0,19 \\
$\mathrm{P}$ & 0,07 & 0,04 \\
$\mathrm{~S}$ & 0,06 & 0,03 \\
$\mathrm{Cl}$ & 0,34 & 0,17 \\
$\mathrm{Ca}$ & 18,00 & 7,90 \\
\hline Total & 100,00 & 100,00 \\
\hline
\end{tabular}


Os elementos presentes em uma proporção inferior a $1 \%$ foram sódio, magnésio, alumínio, sílica, fósforo, enxofre, cloro, apresentando-se em proporções baixas. Os elementos mais abundantes foram o carbono, oxigênio e cálcio. $\mathrm{O}$ carbono constitui o pilar básico das substâncias de origem animal e vegetal e o oxigênio é caracterizado por ser um elemento não metálico altamente reativo, que forma os compostos, especialmente os óxidos.

\subsubsection{Análise dos metais pesados}

Os metais analisados nas amostras do pó residual orgânico foram: cobre, cromo, arsênio, cádmio, chumbo, cobalto, fósforo, níquel e zinco, os quais são apresentados na Tabela 5.3. Quando apresentado o símbolo < LOD, isso significa que a concentração encontrada foi muito baixa, não sendo possível quantifica-la com precisão.

Tabela 5.3 - Metais analisados nas amostras do pó residual orgânico (Fonte: autor)

\begin{tabular}{ccc}
\hline Metais & $\begin{array}{c}\text { Valores } \\
(\mathbf{m g} / \mathbf{l})\end{array}$ & $\begin{array}{c}\text { Límite máximo } \\
(\mathbf{m g} / \mathbf{l})\end{array}$ \\
\hline Cobre & 7,76 & - \\
Cromo & $<$ LOD & 5,00 \\
Arsênio & $<$ LOD & 1,00 \\
Cádmio & $<$ LOD & 0,50 \\
Chumbo & $<$ LOD & 1,00 \\
Cobalto & $<$ LOD & - \\
Fósforo & 72,59 & - \\
Níquel & $<$ LOD & - \\
Zinco & 15,41 & - \\
Mercúrio & $<$ LOD & 0,10 \\
\hline
\end{tabular}

Os elementos considerados metais pesados são cromo, arsênio, cádmio, chumbo e mercúrio, os quais encontram-se em concentrações muito baixas, cumprindo com os limites impostos no anexo F da NBR 10004: 2004 "Resíduos sólidos - Classificação", que identifica os resíduos perigosos devido à sua toxicidade. Dessa forma, o resíduo de pó de resíduo orgânico pode ser classificado como "Resíduo Não Perigoso - Classe II A - Inertes".

\subsubsection{Caracterização física}

Com relação à caracterização física, o pó residual teve superfície específica de $4987 \mathrm{~cm}^{2} / \mathrm{g}$, massa específica de $3,72 \mathrm{~g} / \mathrm{cm}^{3}$, massa unitária $1,54 \mathrm{~g} / \mathrm{cm}^{3}$, módulo de finura de 1,04, material retido acumulado na peneira \# 200 de $0,07 \%$ e na peneira \# 325 de 0,13\%. Comparando com o cimento CPV ARI, o pó apresenta maior superfície específica e menor 
material retido acumulado na peneira \#200, portanto, constitui um produto mais fino que pode atuar como material de enchimento causando melhor empacotamento na pasta de cimento.

\subsection{Caracterização da fibra de sisal}

Na Tabela 5.4 são apresentados os resultados dos ensaios de caracterização física das fibras, como as massas específicas real e aparente e o teor de umidade.

Tabela 5.4 - Massas específicas real e aparente e teor de umidade das fibras de sisal (Fonte: autor)

\begin{tabular}{cccc}
\hline Valores & $\begin{array}{c}\text { Massa específica } \\
\text { real }\left(\mathbf{k g} / \mathbf{m}^{\mathbf{3}}\right)\end{array}$ & $\begin{array}{c}\text { Massa específica } \\
\text { aparente }\left(\mathbf{k g} / \mathbf{m}^{\mathbf{3}}\right)\end{array}$ & $\begin{array}{c}\text { Teor de } \\
\text { umidade }(\boldsymbol{\%})\end{array}$ \\
\hline Média & 970,62 & 740,22 & 10,47 \\
Sd & 31,42 & 30,52 & 0,59 \\
$\mathrm{CV}(\%)$ & 3,24 & 4,12 & 5,68 \\
\hline
\end{tabular}

Segundo Campos (2008), a massa específica real é a relação entre a massa do material seco e seu volume, excluindo-se os poros permeáveis; e a massa específica aparente é a relação entre a massa do material seco e seu volume, incluindo-se os poros permeáveis. Desse modo, a baixa massa específica aparente e a elevada absorção de água constituem características comuns das fibras vegetais, pela grande incidência de poros permeáveis que incluem as lacunas e os lumens.

Em relação ao teor de umidade, essa propriedade apresentou um valor inferior à umidade máxima de 13,5\% estabelecida pela Norma de Identidade, Qualidade, Apresentação e Embalagem da Fibra de Sisal (1984). O motivo desse resultado poderia ser a diferença nas condições ambientais a que as fibras ficaram exposta, com valores baixos de umidade ambiental no interior do laboratório.

A Tabela 5.5 e a Figura 5.3 mostram a absorção de água das fibras medida em tempos preestabelecidos com relação à massa seca. 
Tabela 5.5 - Absorção de água das fibras no tempo (Fonte: autor)

\begin{tabular}{cc}
\hline Tempos & $\begin{array}{c}\text { Absorção de } \\
\text { Água }(\%)\end{array}$ \\
\hline 5 min & 62 \\
30 min & 83 \\
1 hora & 90 \\
2 horas & 101 \\
24 horas & 139 \\
48 horas & 144 \\
72 horas & 149 \\
96 horas & 152 \\
\hline
\end{tabular}

Nos primeiros 30 minutos ocorreu pelo menos 55\% da absorção total, atingindo cerca de $90 \%$ do total após 24 horas. A partir das 36 horas de imersão fica evidente a estabilização do processo.

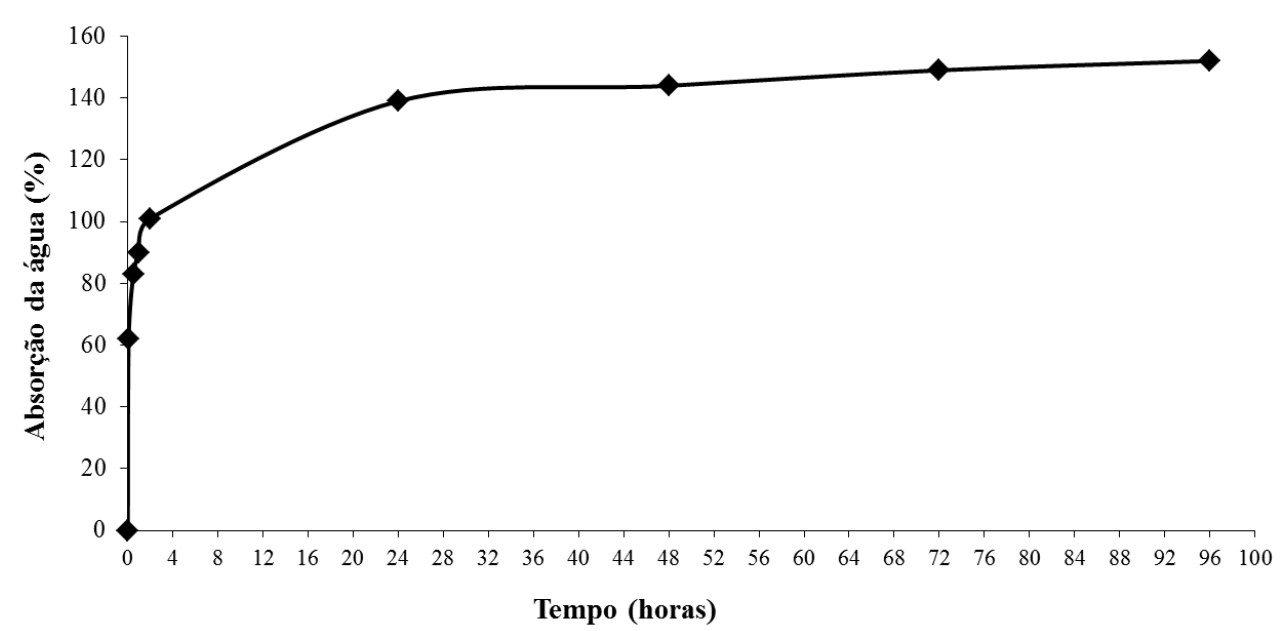

Figura 5.3 - Absorção de água das fibras de sisal ao longo do tempo (Fonte: autor)

Os valores de absorção máxima em 24 horas foram inferiores aos obtidos por Silva (2010) e Savastano (2009), em 193\% e 151\%, respectivamente. Apesar de as fibras estudadas terem capacidade de absorção menor do que as analisadas por diferentes pesquisadores, elas continuaram apresentando valores de absorção significativos, o que pode afetar o grau de aderência com a matriz cimentícia e comprometer a trabalhabilidade da mistura.

\subsection{Caracterização do pó de pedra, areia, pedrisco e cimento.}

A seguir são apresentados os resultados dos ensaios referente à caracterização dos materiais, como pó de pedra, areia, pedrisco e cimento. Por meio dessa caracterização pretende-se obter dados que servirão de base para a pesquisa. 


\subsubsection{Cimento Portland}

As principais características físicas, químicas e mecânicas do cimento CP V-ARI RS e CP III-40 RS constam-se na Tabela 5.6.

Tabela 5.6 - Características físicas e mecânicas do cimento CP V-ARI RS e CP III-40 RS (Fonte: autor).

\begin{tabular}{|c|c|c|}
\hline \multirow{2}{*}{ Ensaio } & \multicolumn{2}{|c|}{ Resultados } \\
\hline & CP V-ARI RS & CP III-40 RS \\
\hline $\begin{array}{l}\text { Finura- Resíduo na peneira \#200 } \\
\text { (abertura } 75 \mu \mathrm{m})(\%)\end{array}$ & 0,15 & 0,24 \\
\hline Massa específica $\left(\mathrm{g} / \mathrm{cm}^{3}\right)$ & 3,12 & 2,96 \\
\hline Área específica $\left(\mathrm{cm}^{2} / \mathrm{g}\right)$ & 4743,00 & 4371,00 \\
\hline Início de pega (h: min) & $1: 50$ & $2: 55$ \\
\hline Fim de pega (h:min) & $2: 43$ & 3:30 \\
\hline Resistência 3 dias (MPa) & 44,40 & 30,00 \\
\hline Resistência 7 dias (MPa) & 47,90 & 38,00 \\
\hline Resistência 28 dias (MPa) & 52,20 & 48,00 \\
\hline Perda ao fogo $(\%)$ & 4,06 & 3,50 \\
\hline $\mathrm{SiO}_{2}(\%)$ & 19,20 & 35,64 \\
\hline $\mathrm{Al}_{2} \mathrm{O}_{3}(\%)$ & 5,97 & 10,24 \\
\hline $\mathrm{CaO}(\%)$ & 63,47 & 41,69 \\
\hline $\mathrm{MgO}(\%)$ & 0,59 & 3,32 \\
\hline Equivalente alcalino (\%) & 0,71 & 0,63 \\
\hline $\mathrm{Cal}$ livre em $\mathrm{CaO}(\%)$ & 2,19 & 1,04 \\
\hline
\end{tabular}

\subsubsection{Agregados miúdos}

A análise granulométrica da areia e do resíduo pó de pedra encontra-se na Tabela 5.7.

Tabela 5.7 - Análise granulométrica da areia e do pó de pedra utilizados nos blocos (Fonte: autor)

\begin{tabular}{cccccc}
\hline & \multicolumn{2}{c}{ Areia } & & \multicolumn{2}{c}{ Pó de pedra } \\
\cline { 2 - 3 } \cline { 5 - 6 } $\begin{array}{c}\text { Peneiras } \\
(\text { mm) }\end{array}$ & $\begin{array}{c}\text { \% Retida } \\
\text { Acumulada }\end{array}$ & $\begin{array}{c}\text { \% Passante } \\
\text { Acumulada }\end{array}$ & & $\begin{array}{c}\text { \% Retida } \\
\text { Acumulada }\end{array}$ & $\begin{array}{c}\text { \% } \\
\text { Passante } \\
\text { Acumulada }\end{array}$ \\
\hline 4,8 & & & & 1,30 & 98,70 \\
2,4 & 2,90 & 99,40 & & 41,00 & 59,00 \\
1,2 & 10,30 & 89,70 & & 65,00 & 35,00 \\
0,6 & 34,20 & 65,80 & & 78,70 & 21,30 \\
0,3 & 70,60 & 29,40 & & 86,40 & 13,60 \\
0,15 & 96,30 & 3,70 & & 91,10 & 8,90 \\
Fundo & 100,00 & 0,00 & & 100,00 & 0,00 \\
\hline
\end{tabular}

O pó de pedra possui uma quantidade de finos $(<0,3 \mathrm{~mm})$ menor do que a areia, 13,6\% do total no pó de pedra e $29,4 \%$ na areia. Uma quantidade excessiva dessa fração pode afetar 
negativamente a resistência mecânica dos blocos (alta superfície específica do material demandando quantidades elevadas de água e pasta de cimento).

A areia atendeu aos requisitos da NBR 7211: 2009 "Agregados para concreto Especificação" e pode ser classificada como areia fina na zona 2 (Figura 5.4).

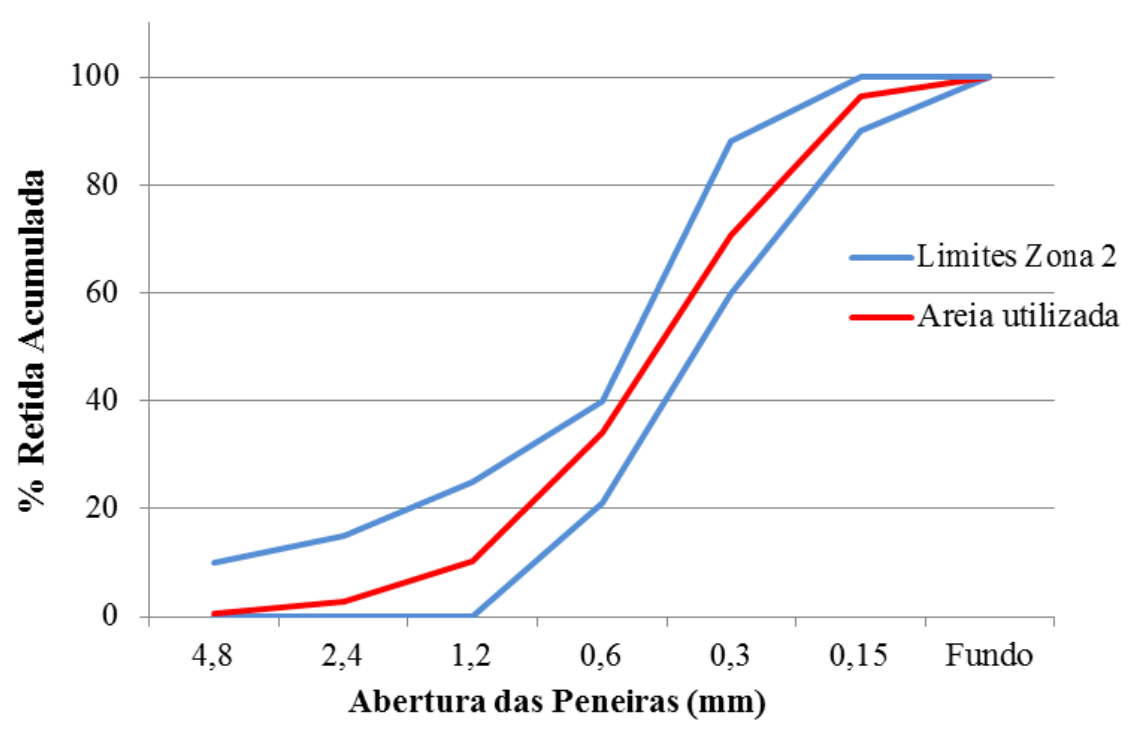

Figura 5.4 - Comparação entre a areia utilizada e a especificada pela NBR 7211: 2009 (Fonte: autor)

A Figura 5.5 mostra a distribuição granulométrica do pó de pedra, que respeitou as especificações da NBR 7211: 2009 para a faixa granulométrica da zona 4 e pode ser considerado como uma areia grossa.

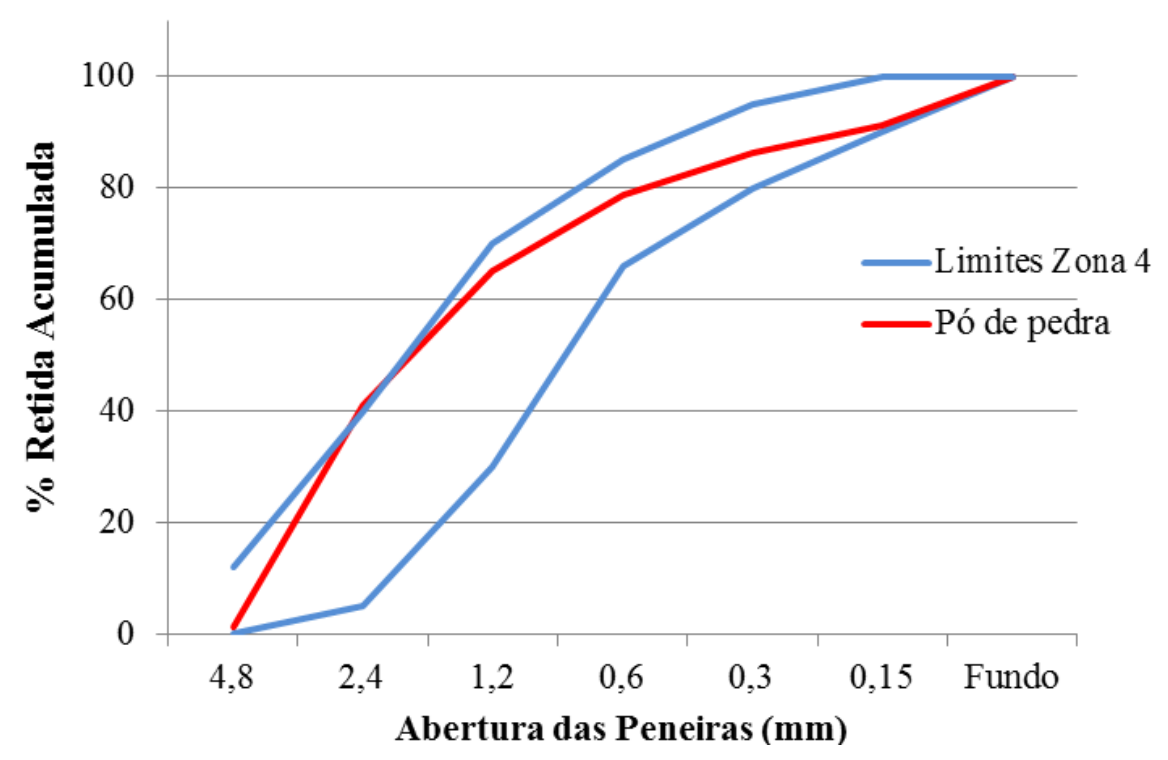

Figura 5.5 - Comparação entre o pó de pedra e os limites especificados NBR 7211: 2009 (Fonte: autor) 
Os resultados obtidos da caracterização dos agregados miúdos são apresentados na Tabela 5.8.

Tabela 5.8 - Características físicas da areia e do pó de pedra (Fonte: autor)

\begin{tabular}{|c|c|c|c|c|c|c|c|}
\hline \multirow[t]{2}{*}{ Materiais } & \multicolumn{2}{|c|}{$\begin{array}{c}\text { Massa } \\
\text { específica } \\
\left(\mathrm{g} / \mathrm{cm}^{3}\right) \\
\end{array}$} & \multicolumn{2}{|c|}{$\begin{array}{l}\text { Massa unitária } \\
\qquad\left(\mathrm{g} / \mathrm{cm}^{3}\right)\end{array}$} & \multirow{2}{*}{$\begin{array}{l}\text { Mod. de } \\
\text { finura }\end{array}$} & \multirow{2}{*}{$\begin{array}{l}\text { Dim. máx. } \\
\text { caract. (mm) }\end{array}$} & \multirow{2}{*}{$\begin{array}{c}\text { Mat. } \\
\text { Pulverulento } \\
(\%)\end{array}$} \\
\hline & Real & Aparente & $\begin{array}{c}\text { Estado } \\
\text { solto }\end{array}$ & $\begin{array}{c}\text { Estado } \\
\text { compactado }\end{array}$ & & & \\
\hline Areia & 2,62 & 2,59 & 1,68 & 1,77 & 2,15 & 2,40 & 0,31 \\
\hline Pó de pedra & 2,89 & 2,80 & 1,72 & 1,92 & 3,64 & 4,80 & 12,58 \\
\hline
\end{tabular}

Ambos os agregados apresentaram o mesmo empacotamento das partículas. Isso pode ser comprovado quando a massa unitária compactada é divida pela massa aparente de cada material, resultando no mesmo número em porcentagem (68\%).

O teor de material pulverulento do pó de pedra mostrou-se acima do permitido pela NBR NM 46: 2003, que fixa os valores máximos de material passante na peneira 0,075 mm em 3\% para concretos submetidos a desgaste superficial e em 5\% para os demais concretos. Segundo Buttler (2007), estudos realizados mostraram que, para o pó de pedra, esse limite pode chegar até $20 \%$, pois estaria melhorando a compacidade, coesão e textura superficial dos blocos.

\subsubsection{Agregado graúdo}

A caracterização física do pedrisco ou brita zero é apresentada na Tabela 5.9.

Tabela 5.9 - Caracterização física do agregado graúdo (Fonte: autor)

\begin{tabular}{|c|c|c|}
\hline \multicolumn{2}{|c|}{ Propriedades } & \multirow{2}{*}{$\begin{array}{c}\text { Brita } \\
\text { \% Retida } \\
\text { acumulada }\end{array}$} \\
\hline \multirow{7}{*}{ 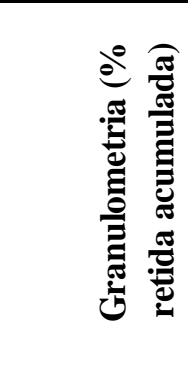 } & $\begin{array}{c}\text { Abertura } \\
\text { peneiras }(\mathbf{m m})\end{array}$ & \\
\hline & 12,5 & 0,00 \\
\hline & 9,5 & 0,50 \\
\hline & 6,3 & 48,30 \\
\hline & 4,8 & 86,00 \\
\hline & 2,4 & 98,80 \\
\hline & Fundo & 100,00 \\
\hline \multicolumn{2}{|c|}{ Dimensão máxima característica } & 9,50 \\
\hline \multicolumn{2}{|c|}{ Módulo de finura } & 5,85 \\
\hline \multicolumn{2}{|c|}{ Massa específica real $\left(\mathrm{g} / \mathrm{cm}^{3}\right)$} & 2,86 \\
\hline \multicolumn{2}{|c|}{ Massa específica aparente $\left(\mathrm{g} / \mathrm{cm}^{3}\right)$} & 2,70 \\
\hline \multicolumn{2}{|c|}{ Massa unitária solta (g/cm³) } & 1,49 \\
\hline \multicolumn{2}{|c|}{ Massa unitária compactada $\left(\mathrm{g} / \mathrm{cm}^{3}\right)$} & 1,68 \\
\hline
\end{tabular}




\subsection{Avaliação das propriedades dos corpos de prova de concreto para cada traço estudado}

São apresentados os resultados dos ensaios realizados nos corpos de prova cilíndricos com o pó de pedra substituindo a areia e com o pó de resíduo orgânico substituindo o cimento. Foram avaliadas as propriedades físicas do concreto fresco e endurecido e a resistência á compressão.

\subsubsection{Corpos de prova com pó de pedra substituindo a areia}

Como foi mencionado no Capítulo 4, foi avaliada a substituição da areia natural por pó de pedra com teores de 0\%, 20\%, 40\%, 60\% e 80\% para cada um dos traços (pobre, médio e rico). A Tabela 4.5 mostrou um resumo da nomenclatura utilizada para cada um dos corpos de prova em função do tipo de traço e dos teores de substituição. Essa terminologia é usada a seguir para cada um dos concretos.

\subsubsection{Propriedades físicas do concreto fresco}

Os ensaios realizados ao concreto fresco foram massa específica, teor de ar e coesão. Os resultados desses ensaios para o traço 1:15 ( $f_{\mathrm{bk}}=4 \mathrm{MPa}$, pobre $)$ encontram-se na Tabela 5.10 .

Tabela 5.10 - Propriedades físicas do concreto fresco com pó de pedra para o traço 1:15 (Fonte: autor).

\begin{tabular}{|c|c|c|c|c|c|c|c|c|c|}
\hline \multirow{2}{*}{$\begin{array}{l}\text { Tipo de } \\
\text { CPs }\end{array}$} & \multicolumn{3}{|c|}{$\begin{array}{c}\text { Massa específica } \\
\text { fresca }\left(\mathrm{g} / \mathrm{cm}^{3}\right)\end{array}$} & \multicolumn{3}{|c|}{ Teor de $\operatorname{ar}(\%)$} & \multicolumn{3}{|c|}{ Coesão (kg) } \\
\hline & Média & Sd & $\mathrm{CV}(\%)$ & Média & Sd & $\mathrm{CV}(\%)$ & Média & Sd & CV (\%) \\
\hline 4-REF & 2,05 & 0,038 & 1,85 & 9,12 & 0,38 & 4,24 & 6,32 & 0,08 & 1,93 \\
\hline 4-P.P20 & 2,07 & 0,026 & 1,25 & 8,96 & 0,29 & 3,18 & 5,70 & 0,07 & 1,37 \\
\hline 4-P.P40 & 2,10 & 0,025 & 1,19 & 8,36 & 0,35 & 4,18 & 6,72 & 0,05 & 0,86 \\
\hline 4-P.P60 & 2,18 & 0,023 & 1,05 & 7,93 & 0,31 & 3,90 & 7,10 & 0,06 & 0,88 \\
\hline 4-P.P80 & 2,09 & 0,016 & 0,76 & 9,42 & 0,47 & 4,99 & 6,55 & 0,10 & 1,58 \\
\hline
\end{tabular}

A massa específica mais elevada observada corresponde ao concreto com $60 \%$ de pó de pedra e é resultante do melhor empacotamento dos agregados. Com relação à taxa de ar incorporado, o menor valor corresponde ao mesmo concreto. No que concerne ao ensaio de coesão, o maior valor obtido também foi para o corpo de prova 4-P.P60.

A Tabela 5.11 mostra os resultados dos mesmos ensaios realizados ao concreto fresco para o traço 1:10 $\left(\mathrm{f}_{\mathrm{bk}}=8 \mathrm{MPa}\right.$, médio $)$. 
Tabela 5.11 - Propriedades físicas do concreto fresco com pó de pedra para o traço 1:10 (Fonte: autor)

\begin{tabular}{|c|c|c|c|c|c|c|c|c|c|}
\hline \multirow{2}{*}{$\begin{array}{l}\text { Tipo de } \\
\text { CPs }\end{array}$} & \multicolumn{3}{|c|}{$\begin{array}{c}\text { Massa específica } \\
\text { fresca }\left(\mathrm{g} / \mathrm{cm}^{3}\right)\end{array}$} & \multicolumn{3}{|c|}{ Teor de $\operatorname{ar}(\%)$} & \multicolumn{3}{|c|}{ Coesão (kg) } \\
\hline & Média & Sd & $\mathrm{CV}(\%)$ & Média & Sd & $\mathrm{CV}(\%)$ & Média & Sd & $\mathrm{CV}(\%)$ \\
\hline 8-REF & 2,10 & 0,041 & 1,91 & 7,91 & 0.31 & 3,93 & 7,87 & 0.24 & 3,05 \\
\hline 8-P.P20 & 2,14 & 0,039 & 1.85 & 7,89 & 0.26 & 3,28 & 6,65 & 0.35 & 5,26 \\
\hline 8-P.P40 & 2,16 & 0,031 & 1,43 & 6,59 & 0.36 & 5,46 & 6,79 & 0.45 & 6,62 \\
\hline 8-P.P60 & 2.21 & 0,040 & 1,80 & 6,42 & 0,41 & 6,38 & 8,11 & 0,30 & 3,70 \\
\hline 8-P.P80 & 2,13 & 0,035 & 1,64 & 7,10 & 0.35 & 4,92 & 7,42 & 0.21 & 2,83 \\
\hline
\end{tabular}

Para o traço médio, os melhores resultados de massa específica, teor de ar e coesão correspondem ao concreto com $60 \%$ de pó de pedra substituindo a areia.

A Tabela 5.12 apresenta agora os resultados do concreto fresco para o traço 1:6 $\left(\mathrm{f}_{\mathrm{bk}}=\right.$ $12 \mathrm{MPa}$, rico).

Tabela 5.12 - Propriedades físicas do concreto fresco com pó de pedra para o traço 1:6 (Fonte: autor)

\begin{tabular}{|c|c|c|c|c|c|c|c|c|c|}
\hline \multirow{2}{*}{$\begin{array}{l}\text { Tipo de } \\
\text { CPs }\end{array}$} & \multicolumn{3}{|c|}{$\begin{array}{c}\text { Massa específica } \\
\text { fresca }\left(\mathrm{g} / \mathrm{cm}^{3}\right)\end{array}$} & \multicolumn{3}{|c|}{ Teor de ar $(\%)$} & \multicolumn{3}{|c|}{ Coesão (kg) } \\
\hline & Média & Sd & $\mathrm{CV}(\%)$ & Média & Sd & $\overline{C V}(\%)$ & Média & Sd & $\mathrm{CV}(\%)$ \\
\hline 12-REF & 2,18 & 0,052 & 2,38 & 5,40 & 0,39 & 7,22 & 9,54 & 0,26 & 2,72 \\
\hline 12-P.P20 & 2,19 & 0,058 & 2,64 & 5,38 & 0,37 & 6,87 & 10,17 & 0,48 & 4,72 \\
\hline 12-P.P40 & 2,23 & 0,047 & 2,10 & 5,29 & 0,35 & 6,61 & 14,08 & 0,37 & 2,63 \\
\hline 12-P.P60 & 2,20 & 0,062 & 2,82 & 5,35 & 0,51 & 9,53 & 13,65 & 0,51 & 3,74 \\
\hline 12-P.P80 & 2,06 & 0,059 & 2,86 & 6,22 & 0,42 & 6,75 & 12,84 & 0,29 & 2,26 \\
\hline
\end{tabular}

Segundo os valores mostrados na Tabela 5.12, a maior massa específica, menor taxa de ar e maior coesão correspondem ao concreto com $40 \%$ de pó de pedra substituindo a areia.

Fazendo-se uma comparação entre os três traços estudados, pode-se observar que os maiores valores de massa específica foram obtidos para as dosagens com maior consumo de cimento, o seja, o traço rico 1:6. Do mesmo modo, à medida que aumentou o consumo do cimento, houve uma diminuição do teor de ar incorporado. Assim, as dosagens do traço 1:6 e do traço 1:15 apresentaram os menores e maiores teores de ar incorporado, respectivamente. Com relação ao ensaio de coesão, foram obtidos os maiores valores para as dosagens do traço 1:6 e os menores valores para o traço 1:15. Diante dos resultados, pode-se afirmar que a coesão é proporcional ao aumento do consumo de cimento da mistura e a elevação do teor de finos. Todos os concretos são adequados para a produção de blocos, uma vez que os valores de coesão foram superiores a $6 \mathrm{~kg}$.

Quanto às propriedades físicas do concreto fresco, pode-se concluir que os concretos com $60 \%$ de pó de pedra substituindo a areia para os traços 1:15 e 1:10 e com 40\% para o 
traço 1:6 apresentaram maior massa específica, menor taxa de ar incorporado e maior coesão. Isso se deve ao melhor empacotamento dos agregados causado pelo resíduo, que preencheu os vazios e diminuiu a porosidade.

\subsubsection{Propriedades físicas do concreto endurecido}

Os ensaios realizados para a caracterização física do concreto endurecido foram massa específica, absorção de água e índice de vazios. Os resultados desses ensaios para o traço 1:15 $\left(\mathrm{f}_{\mathrm{bk}}=4 \mathrm{MPa}\right.$, pobre) encontram-se na Tabela 5.13.

Tabela 5.13 - Propriedades físicas do concreto endurecido com pó de pedra para o traço 1:15 (Fonte: autor)

\begin{tabular}{|c|c|c|c|c|c|c|c|c|c|}
\hline \multirow{2}{*}{$\begin{array}{l}\text { Tipo de } \\
\text { CPs }\end{array}$} & \multicolumn{3}{|c|}{$\begin{array}{l}\text { Massa específica } \\
\text { endurecida }\left(\mathrm{g} / \mathrm{cm}^{3}\right)\end{array}$} & \multicolumn{3}{|c|}{$\begin{array}{c}\text { Absorção de água } \\
(\%)\end{array}$} & \multicolumn{3}{|c|}{$\begin{array}{c}\text { Índice de vazios } \\
(\%)\end{array}$} \\
\hline & Média & Sd & $\mathrm{CV}(\%)$ & Média & Sd & CV (\%) & Média & Sd & CV (\%) \\
\hline 4-REF & 2,53 & 0,036 & 1,42 & 7,43 & 0,38 & 5,11 & 12,64 & 0,69 & 5,46 \\
\hline 4-P.P20 & 2,60 & 0,047 & 1,81 & 6,95 & 0,36 & 5,18 & 11,14 & 0,71 & 6,37 \\
\hline 4-P.P40 & 2,67 & 0,040 & 1,50 & 6,94 & 0,42 & 6,04 & 11,01 & 0,49 & 5,44 \\
\hline 4-P.P60 & 2,74 & 0,051 & 1,86 & 6,39 & 0,27 & 4,27 & 10,86 & 0,56 & 5,21 \\
\hline 4-P.P80 & 2,71 & 0,034 & 1,26 & 7,06 & 0,35 & 4,99 & 10,99 & 0,52 & 4,77 \\
\hline
\end{tabular}

O maior valor de massa específica do concreto endurecido e os menores valores de absorção e índice de vazios correspondem ao concreto 4-P.P60. Dessa forma, o teor de 60\% de pó de pedra substituindo a areia ocupou o maior número de vazios na mistura, quando comparado com os teores de $20 \%, 40 \%$ e $80 \%$.

A Tabela 5.14 mostra os resultados dos ensaios para o traço 1:10 ( $f_{\mathrm{bk}}=8 \mathrm{MPa}$, médio).

Tabela 5.14 -Propriedades físicas do concreto endurecido com pó de pedra para o traço 1:10 (Fonte: autor)

\begin{tabular}{|c|c|c|c|c|c|c|c|c|c|}
\hline \multirow{2}{*}{$\begin{array}{l}\text { Tipo de } \\
\text { CPs }\end{array}$} & \multicolumn{3}{|c|}{$\begin{array}{l}\text { Massa específica } \\
\text { endurecida }\left(\mathrm{g} / \mathrm{cm}^{3}\right)\end{array}$} & \multicolumn{3}{|c|}{$\begin{array}{c}\text { Absorção de água } \\
(\%)\end{array}$} & \multicolumn{3}{|c|}{$\begin{array}{c}\text { Índice de vazios } \\
(\%) \\
\end{array}$} \\
\hline & Média & Sd & $\mathrm{CV}(\%)$ & Média & Sd & CV (\%) & Média & Sd & $\mathrm{CV}(\%)$ \\
\hline 8-REF & 2,62 & 0,046 & 1,74 & 5,84 & 0,31 & 5,30 & 11,62 & 0,65 & 5,59 \\
\hline 8-P.P20 & 2,68 & 0,052 & 1,94 & 5,62 & 0,27 & 4,80 & 11,55 & 0,58 & 5,04 \\
\hline 8-P.P40 & 2,72 & 0,048 & 1,78 & 5,59 & 0,32 & 5,68 & 11,04 & 0,51 & 4,61 \\
\hline 8-P.P60 & 2,78 & 0,052 & 1,88 & 4,81 & 0,23 & 4,96 & 10,85 & 0,49 & 4,55 \\
\hline 8-P.P80 & 2,67 & 0,045 & 1,68 & 5,67 & 0,31 & 5,58 & 11,59 & 0,68 & 5,03 \\
\hline
\end{tabular}

Segundo os resultados da Tabela 5.14, o concreto que teve o maior valor de massa específica e os menores valores de absorção de água e índice de vazios foi o 8-P.P60. Nesse caso, a porcentagem de $60 \%$ de pó provocou o melhor empacotamento dos agregados. 
Já a Tabela 5.15 mostra os resultados dos concretos estudados para o traço 1:6 $\left(f_{\mathrm{bk}}=\right.$ $12 \mathrm{MPa}$, rico).

Tabela 5.15 - Propriedades físicas do concreto endurecido com pó de pedra para o traço 1:6 (Fonte: autor)

\begin{tabular}{|c|c|c|c|c|c|c|c|c|c|}
\hline \multirow{2}{*}{$\begin{array}{l}\text { Tipo de } \\
\text { CPs }\end{array}$} & \multicolumn{3}{|c|}{$\begin{array}{l}\text { Massa específica } \\
\text { endurecida }\left(\mathrm{g} / \mathrm{cm}^{3}\right)\end{array}$} & \multicolumn{3}{|c|}{$\begin{array}{c}\text { Absorção de água } \\
(\%)\end{array}$} & \multicolumn{3}{|c|}{$\begin{array}{c}\text { Índice de vazios } \\
(\%)\end{array}$} \\
\hline & Média & Sd & $\mathrm{CV}(\%)$ & Média & Sd & $\mathrm{CV}(\%)$ & Média & Sd & CV (\%) \\
\hline 12-REF & 2,66 & 0,053 & 2,00 & 5,31 & 0,26 & 5,08 & 10,14 & 0,45 & 4,41 \\
\hline 12-P.P20 & 2,69 & 0,048 & 1,81 & 5,17 & 0,30 & 5,92 & 10,10 & 0,47 & 4,62 \\
\hline 12-P.P40 & 2,81 & 0,051 & 1,82 & 5,01 & 0,28 & 5,58 & 9,98 & 0,47 & 4,72 \\
\hline 12-P.P60 & 2,77 & 0,047 & 1,70 & 5,13 & 0,27 & 5,36 & 10,06 & 0,41 & 4,07 \\
\hline 12-P.P80 & 2,76 & 0,052 & 1,88 & 5,16 & 0,30 & 5,89 & 10,03 & 0,45 & 4,49 \\
\hline
\end{tabular}

Na dosagem correspondente ao maior consumo de cimento, a porcentagem ideal de pó de pedra no concreto foi $40 \%$. Os resultados mostraram, para esse concreto, o melhor comportamento da mistura nas propriedades avaliadas.

Com relação aos três traços, o traço 1:6 apresentou os maiores valores de massa específica e os menores valores de absorção de água e índice de vazios com relação aos traços 1:10 e 1:15. Pode-se afirmar que o aumento de cimento na mistura é proporcional à maior massa específica e menor absorção e índice de vazios.

Do mesmo modo que aconteceu no concreto fresco, a porcentagem ideal de pó de pedra para o concreto endurecido foi de $60 \%$ para os traços 1:15 e 1:10 e de $40 \%$ para o traço 1:6.

\subsubsection{Resistência à compressão dos corpos de prova com pó de pedra}

Os resultados de resistência à compressão dos corpos de prova com pó de pedra para cada um dos traços são apresentados no item a seguir. Para a análise desses resultados foi utilizado a técnica do Bootstrap que permite obterem-se intervalos de confiança dos parâmetros estatísticos da população para uma confiabilidade determinada. Os intervalos de confiança são mais informativos do que um resultado simples de apenas um valor, já que proporcionam uma gama de valores plausíveis para um parâmetro desconhecido. Dessa forma, pode-se fazer uma melhor interpretação dos resultados e formar base para que as decisões sejam tomadas sob o menor risco possível. Esse estudo é apresentado no Apêndice A, no qual é explicado em que consiste a técnica do Bootstrap e como é realizado o procedimento para a análise dos resultados.

Também foi realizada a análise das diferenças entre duas médias aplicando-se a técnica do Bootstrap, com a qual as diferentes hipóteses nulas podem ser analisadas, como 
$H_{01}: u_{1}<u_{2}, H_{02}: u_{1}=u_{2}$, e $H_{03}: u_{1}>u_{2}$. Em vista disso foi possível avaliar a probabilidade tanto de aceitação quanto de rejeição das hipóteses nulas. Essas probabilidades são mais informativas do que um simples resultado do teste de hipótese, no qual apenas se aceita ou rejeita a hipótese nula. $\mathrm{O}$ procedimento encontra-se bem detalhado no Apêndice B.

\section{$\underline{\text { Traco 1:15 }}$}

A Tabela 5.16 mostra os intervalos de confiança da média, desvio padrão e coeficiente de variação da resistência à compressão da população de concretos estudados para uma confiabilidade de $95 \%$, correspondente ao traço 1:15.

Tabela 5.16 -Resistência à compressão do concreto com pó de pedra para o traço 1:15 (Fonte: autor)

\begin{tabular}{|c|c|c|c|c|c|c|}
\hline \multirow{3}{*}{$\begin{array}{l}\text { Tipo de } \\
\text { CPs }\end{array}$} & \multicolumn{6}{|c|}{ Resistência à compressão (MPa) } \\
\hline & \multirow{2}{*}{\multicolumn{2}{|c|}{$\frac{\text { Média }}{\text { Inferior Superior }}$}} & \multirow{2}{*}{\multicolumn{2}{|c|}{\begin{tabular}{|c|} 
Sd \\
Inferior Superior
\end{tabular}}} & \multirow{2}{*}{\multicolumn{2}{|c|}{$\begin{array}{c}\text { CV (\%) } \\
\text { Inferior Superior }\end{array}$}} \\
\hline & & & & & & \\
\hline $4-\mathrm{RI}$ & 14,80 & 15,60 & 0,33 & 0,78 & 2,23 & 5,00 \\
\hline 4-P.P20 & 15,87 & 42 & 0 & 0,5 & 1,20 & 3,53 \\
\hline 4-P.P40 & 16,96 & 17,70 & 0,38 & 0,66 & 2,24 & 3,73 \\
\hline 4-P.P60 & 21,64 & 22,42 & 0,30 & 0,81 & 1,38 & 3,61 \\
\hline 4-P.P80 & 14,33 & 15,04 & 0,30 & 0,64 & 2,09 & 4,25 \\
\hline
\end{tabular}

Pode-se notar que o intervalo de valores superiores corresponde ao concreto 4-P.P60. Para uma melhor compreensão dos resultados mostra-se na Figura 5.6 o diagrama de caixa dos valores médios da resistência de cada um dos concretos estudados. 


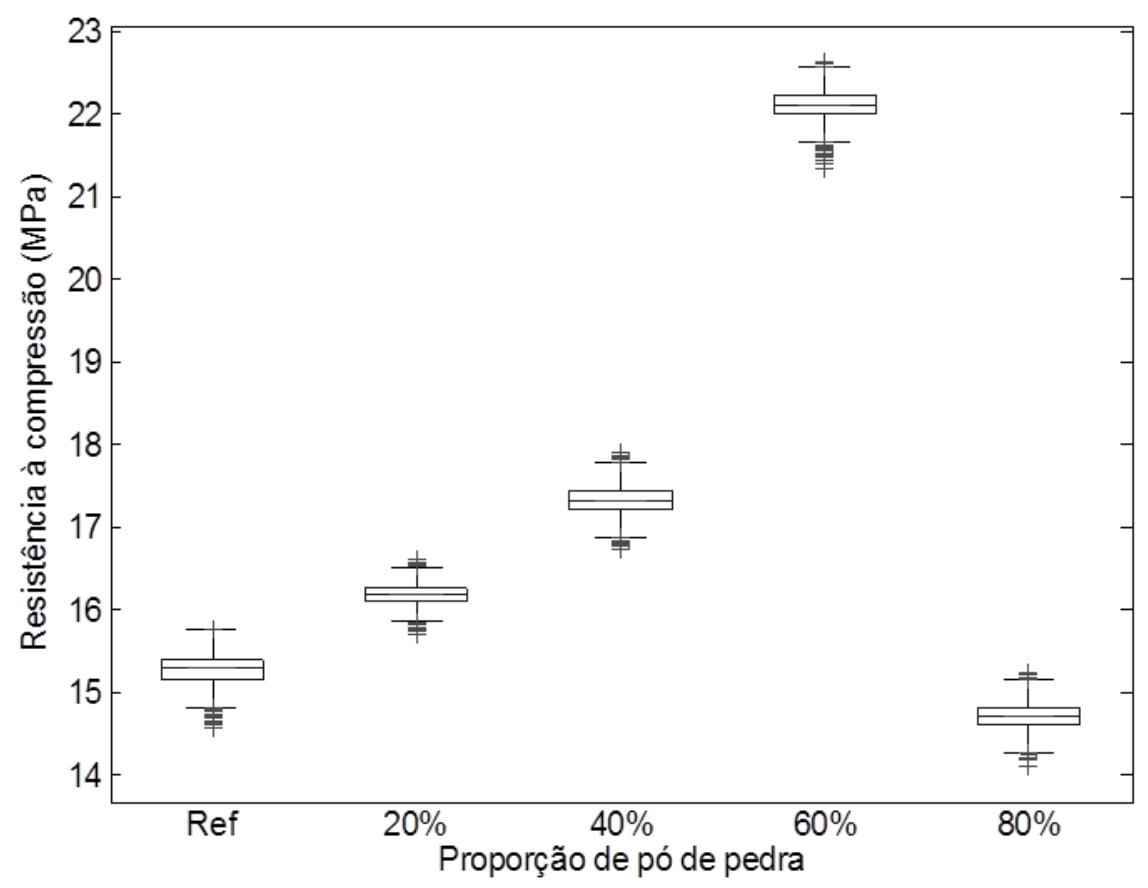

Figura 5.6 - Diagrama de caixa para os dados de resistência à compressão do concreto com pó de pedra para o traço 1:15 (Fonte: autor)

Segundo a posição relativa das caixas no diagrama, a caixa com o teor de $60 \%$ de pó está acima do resto. Por conseguinte, esse concreto alcançou o maior valor de resistência à compressão, indicando a melhor proporção de pó de pedra no concreto. Já para o resto dos concretos a resistência foi menor. Possivelmente, o excesso ou a falta de areia provocou maior número de vazios no concreto e a pasta de cimento não permitiu o preenchimento desses vazios.

Analisando a forma da distribuição dos valores nota-se que a posição da mediana dentro das caixas encontra-se equidistante dos extremos, portanto, os dados apresentam uma distribuição simétrica. Outra análise interessante é com relação à variabilidade dos valores dos cinco grupos por meio das dimensões das caixas, os quais mostram que não existe evidência de dispersão dos mesmos, sob o aspecto visual. Isso pode ser comprovado também nos intervalos de confiança do desvio padrão na Tabela 5.16, dado que os valores foram baixos e inferiores a $2 \mathrm{MPa}$, valor especificado na norma NBR 12655:2015 "Concreto - Preparo, controle e recebimento". À vista disso, pode-se disser que o processo de produção dos corpos de prova no laboratório com adição de pó de pedra no concreto foi rigoroso e homogêneo.

A Tabela 5.17 mostra a probabilidade de que as médias sejam estatisticamente iguais e diferentes para um nível de confiança de 95\%. A tabela é uma matriz, onde a cada valor correspondem duas populações, $u_{1}$ localizada na fila e $u_{2}$ na coluna. São mostradas as probabilidades de aceitação das três hipóteses nulas $\mathrm{H}_{01}\left(\mathrm{u}_{1}<\mathrm{u}_{2}\right), \mathrm{H}_{02}\left(\mathrm{u}_{1}=\mathrm{u}_{2}\right)$ e $\mathrm{H}_{03}\left(\mathrm{u}_{1}>\mathrm{u}_{2}\right)$. 
Na diagonal encontra-se sempre uma porcentagem de $100 \%$ para a hipótese nula $\mathrm{H}_{02}$, porque se está comparando a mesma população. Nos testes de hipóteses foi utilizado um nível de significância de $5 \%$.

Tabela 5.17 -Probabilidade de que as hipóteses nulas sejam aceitas para o concreto com pó de pedra para o traço 1:15 (Fonte: autor)

\begin{tabular}{|c|c|c|c|c|c|c|c|c|c|c|c|c|c|c|c|}
\hline \multirow{2}{*}{$\begin{array}{l}\text { Tipo de } \\
\text { concreto }\end{array}$} & \multicolumn{3}{|c|}{ 4-REF } & \multicolumn{3}{|c|}{ 4-P.P20 } & \multicolumn{3}{|c|}{ 4-P.P40 } & \multicolumn{3}{|c|}{ 4-P.P60 } & \multicolumn{3}{|c|}{ 4-P.P80 } \\
\hline & $\mathbf{H}_{01}$ & $\mathbf{H}_{02}$ & $\mathbf{H}_{\mathbf{0 3}}$ & $\mathbf{H}_{01}$ & $\mathbf{H}_{02}$ & $\mathrm{H}_{03}$ & $\mathbf{H}_{01}$ & $\mathbf{H}_{02}$ & $\mathbf{H}_{03}$ & $\mathbf{H}_{01}$ & $\mathbf{H}_{02}$ & $\mathbf{H}_{03}$ & $\mathbf{H}_{01}$ & $\mathbf{H}_{02}$ & $\mathbf{H}_{03}$ \\
\hline 4-REF & 0 & 100 & 0 & 100 & 0 & 0 & 100 & 0 & 0 & 100 & 0 & 0 & 0 & 30,48 & 69,52 \\
\hline 4-P.P20 & 0 & 0 & 100 & 0 & 100 & 0 & 100 & 0 & 0 & 100 & 0 & 0 & 0 & 0 & 100 \\
\hline 4-P.P40 & 0 & 0 & 100 & 0 & 0 & 100 & 0 & 100 & 0 & 100 & 0 & 0 & 0 & 0 & 100 \\
\hline 4-P.P60 & 0 & 0 & 100 & 0 & 0 & 100 & 0 & 0 & 100 & 0 & 100 & 0 & 0 & 0 & 100 \\
\hline 4-P.P80 & 69,52 & 30,48 & 0 & 100 & 0 & 0 & 100 & 0 & 0 & 100 & 0 & 0 & 0 & 100 & 0 \\
\hline
\end{tabular}

Segundo os valores da Tabela 5.17, comparando-se o concreto 4-P.P60 (fila 4) com o resto das misturas (todas as colunas $\mathrm{H}_{03}$ ), nota-se que ele apresentou $100 \%$ de probabilidade de que a hipótese nula $\mathrm{H}_{03}\left(\mathrm{u}_{1}>\mathrm{u}_{2}\right)$ seja aceita, portanto, existe $100 \%$ de probabilidade que a resistência à compressão seja estatisticamente maior. O concreto com $80 \%$ de pó de pedra (fila 5) alcançou resultados estatisticamente inferiores com relação ao concreto de referência (coluna 1), devido a que há $69,52 \%$ de probabilidade da sua resistência ser menor $\left(\mathrm{H}_{01}\right.$ : $\mathrm{u}_{1}<$ $\left.\mathrm{u}_{2}\right)$ e $30,48 \%$ de ser igual $\left(\mathrm{H}_{02}: \mathrm{u}_{1}=\mathrm{u}_{2}\right)$ à mistura sem pó.

\section{Traco 1:10}

Para esta dosagem de concreto, a Tabela 5.18 mostra os intervalos de confiança da média, desvio padrão e coeficiente de variação da resistência à compressão da população para uma confiabilidade de $95 \%$.

Tabela 5.18 - Resistência à compressão do concreto com pó de pedra para o traço 1:10 (Fonte: autor)

\begin{tabular}{|c|c|c|c|c|c|c|}
\hline \multirow{3}{*}{$\begin{array}{l}\text { Tipo de } \\
\text { CPs }\end{array}$} & \multicolumn{6}{|c|}{ Resistência à compressão (MPa) } \\
\hline & \multirow{2}{*}{\multicolumn{2}{|c|}{$\begin{array}{c}\text { Média } \\
\text { Inferior Superior }\end{array}$}} & \multirow{2}{*}{\multicolumn{2}{|c|}{\begin{tabular}{|c|} 
Sd \\
Inferior Superior
\end{tabular}}} & \multirow{2}{*}{\multicolumn{2}{|c|}{$\begin{array}{c}\text { CV (\%) } \\
\text { Inferior Superior }\end{array}$}} \\
\hline & & & & & & \\
\hline 8-REF & 26,68 & 27,82 & 0,48 & 1,11 & 1,80 & 3,99 \\
\hline 8-P.P20 & 27,61 & 28,71 & 0,51 & 1,09 & 1,85 & 3,79 \\
\hline 8-P.P40 & 30,23 & 31,09 & 0,37 & 0,85 & 1,22 & 2,73 \\
\hline 8-P.P60 & 32,66 & 33,92 & 0,65 & 1,17 & 1,97 & 3,41 \\
\hline 8-P.P80 & 30,61 & 31,74 & 0,43 & 1,13 & 1,40 & 3,56 \\
\hline
\end{tabular}


No traço médio nota-se que o concreto com $60 \%$ de pó teve resistência à compressão maior com relação ao resto dos concretos, como aconteceu com o traço pobre. A Figura 5.7 mostra o diagrama de caixa dos valores médios da resistência de cada um dos concretos.

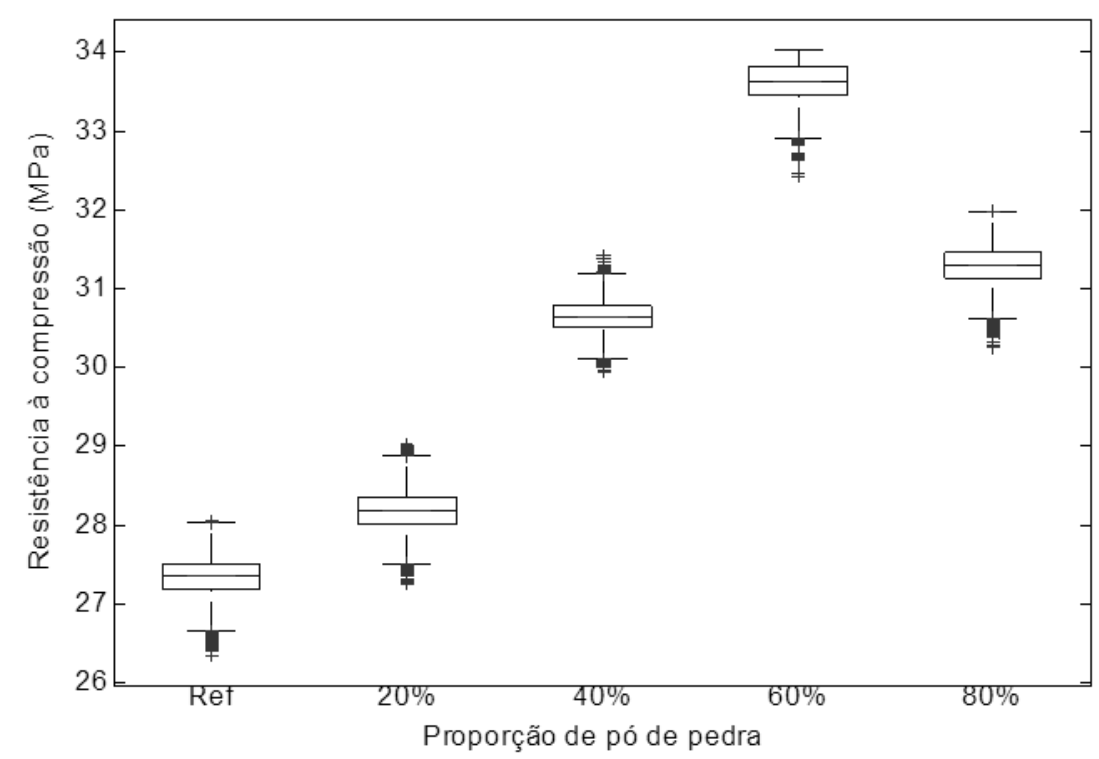

Figura 5.7 -Diagrama de caixa para os dados da resistência à compressão do concreto com pó de pedra para o traço 1:10 (Fonte: autor)

Para essa dosagem, o concreto de referência teve menor resistência. Com relação às misturas feitas com adição do pó, comprovando a afirmativa anterior, a porcentagem que ofereceu melhor comportamento mecânico ao concreto foi de $60 \%$. De forma geral, os dados dos cinco grupos apresentaram uma distribuição simétrica e não existe evidência de dispersão dos mesmos, sob o aspecto visual.

A Tabela 5.19 mostra a probabilidade, para um nível de confiança de 95\%, com que duas médias foram iguais ou diferentes.

Tabela 5.19 - Probabilidade de que as hipóteses nulas sejam aceitas para o concreto com pó de pedra para o traço 1:10 (Fonte: autor)

\begin{tabular}{|c|c|c|c|c|c|c|c|c|c|c|c|c|c|c|c|}
\hline \multirow{2}{*}{$\begin{array}{c}\text { Tipo de } \\
\text { concreto }\end{array}$} & \multicolumn{3}{|c|}{ 8-REF } & \multicolumn{3}{|c|}{ 8-P.P20 } & \multicolumn{3}{|c|}{ 8-P.P40 } & \multicolumn{3}{|c|}{ 8-P.P60 } & \multicolumn{3}{|c|}{ 8-P.P80 } \\
\hline & $\mathrm{H}_{01}$ & $\mathrm{H}_{02}$ & $\mathrm{H}_{03}$ & $\mathrm{H}_{01}$ & $\mathbf{H}_{02}$ & $\mathrm{H}_{03}$ & $\mathrm{H}_{01}$ & $\mathbf{H}_{02}$ & $\mathbf{H}_{03}$ & $\mathrm{I}_{01}$ & $\mathrm{H}_{02}$ & $\mathbf{H}_{03}$ & $\mathbf{H}_{01}$ & $\mathbf{H}_{02}$ & $\mathbf{H}_{03}$ \\
\hline 8-REF & 0 & 100 & 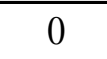 & 85,78 & 14,22 & 0 & 00 & 0 & - & 0 & 0 & ${ }_{1}$ & 100 & 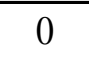 & 0 \\
\hline & 0 & 14,2 & 85 & 0 & 10 & 0 & 100 & 0 & 0 & 0 & 0 & & 100 & 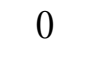 & 0 \\
\hline 8-P & 0 & 0 & 100 & 0 & 0 & 10 & 0 & 100 & 0 & 100 & 0 & ( & 61,83 & 38,17 & 0 \\
\hline 8-P.P & 0 & 0 & 100 & 0 & 0 & 100 & 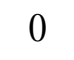 & 0 & 100 & 0 & 100 & 0 & 0 & 0 & 100 \\
\hline 8-P.P80 & 0 & 0 & 100 & 0 & 0 & 100 & 0 & 38,17 & 61,83 & 100 & 0 & 0 & 0 & 100 & 0 \\
\hline
\end{tabular}

Nota-se que o concreto 8-P.P60 teve $100 \%$ de probabilidade de a hipótese nula $\mathrm{H}_{03}\left(\mathrm{u}_{1}>\mathrm{u}_{2}\right)$ seja aceita, quando comparado com os concretos restantes. Desse modo, para um 
nível de significância de 5\%, a resistência à compressão da mistura com $60 \%$ de pó foi estatisticamente maior.

\section{$\underline{\text { Traco 1:6 }}$}

A Tabela 5.20 mostra os intervalos de confiança da média, desvio padrão e coeficiente de variação da resistência à compressão da população para uma confiabilidade de 95\%, correspondente ao traço 1:6.

Tabela 5.20 -Resistência à compressão do concreto com pó de pedra para o traço 1:6 (Fonte: autor)

\begin{tabular}{|c|c|c|c|c|c|c|}
\hline \multirow{3}{*}{$\begin{array}{l}\text { Tipo de } \\
\text { CPs }\end{array}$} & \multicolumn{6}{|c|}{ Resistência à compressão (MPa) } \\
\hline & & dia & & d & CV & $(\%)$ \\
\hline & Inferior & Superior & Inferior & Superior & Inferior & Superior \\
\hline 12-REF & 41,01 & 42,45 & 0,51 & 1,46 & 1,24 & 3,44 \\
\hline 12-P.P20 & 41,88 & 43,34 & 0,63 & 1,54 & 1,50 & 3,55 \\
\hline 12-P.P40 & 49,57 & 51,27 & 0,46 & 1,69 & 0,93 & 3,29 \\
\hline 12-P.P60 & 43,85 & 45,03 & 0,52 & 1,22 & 1,86 & 2,71 \\
\hline 12-P.P80 & 43,01 & 44,38 & 0,55 & 1,46 & 1,28 & 3,29 \\
\hline
\end{tabular}

O concreto que teve maior resistência foi o 12-P.P40. O diagrama de caixa apresentado na Figura 5.8 permite uma melhor visualização dos resultados.

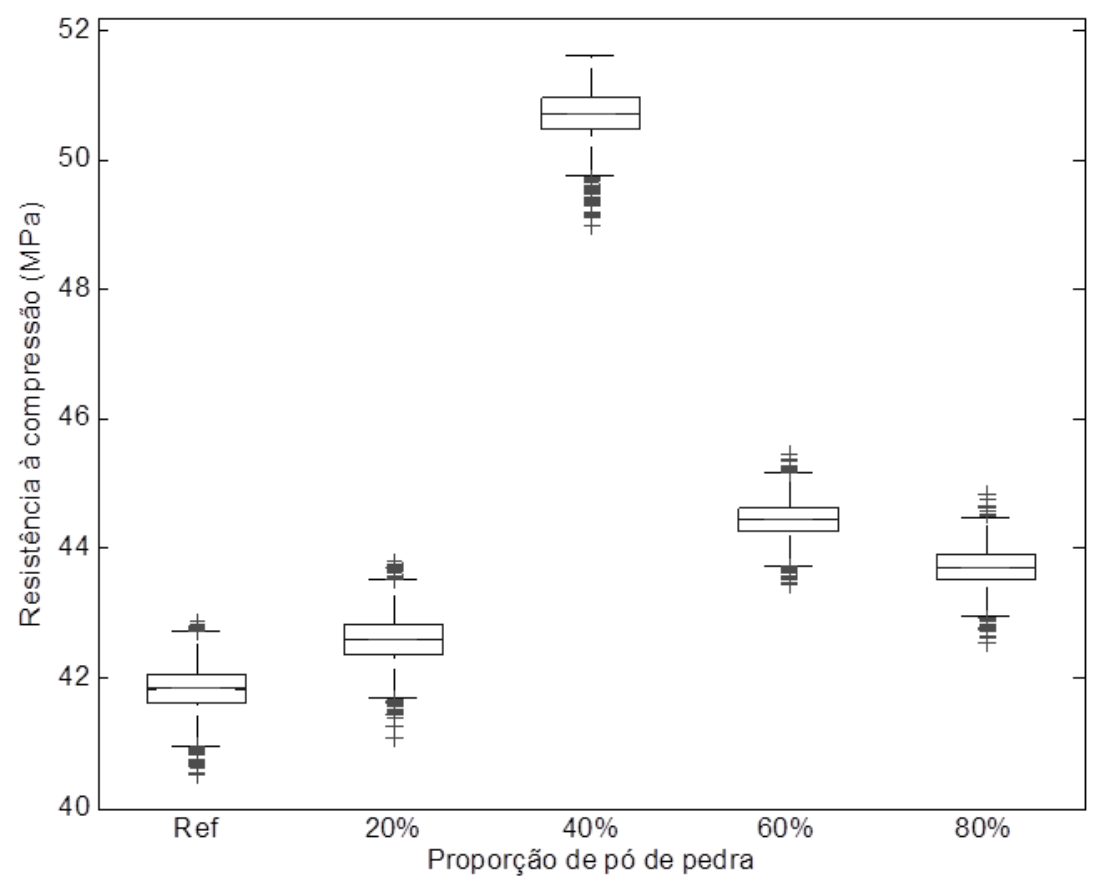

Figura 5.8 - Diagrama de caixa para os dados da resistência à compressão do concreto com pó de pedra para o traço 1:6 (Fonte: autor) 
Para essa dosagem que teve o maior consumo de cimento, a melhor proporção de pó de pedra no concreto foi $40 \%$. Para comprovar se a resistência à compressão foi significativamente superior é mostrada a Tabela 5.21.

Tabela 5.21 - Probabilidade de que as hipóteses nulas sejam aceitas para o concreto com pó de pedra para o traço 1:6 (Fonte: autor)

\begin{tabular}{|c|c|c|c|c|c|c|c|c|c|c|c|c|c|c|c|}
\hline \multirow{2}{*}{$\begin{array}{l}\text { Tipo de } \\
\text { concreto }\end{array}$} & \multicolumn{3}{|c|}{ 12-REF } & \multicolumn{3}{|c|}{ 12-P.P20 } & \multicolumn{3}{|c|}{ 12-P.P40 } & \multicolumn{3}{|c|}{ 12-P.P60 } & \multicolumn{3}{|c|}{ 12-P.P80 } \\
\hline & $\mathrm{H}_{01}$ & $\mathrm{H}_{02}$ & $\mathbf{H}_{03}$ & $\mathrm{H}_{01}$ & $\mathrm{H}_{02}$ & $\mathrm{H}_{03}$ & $\mathrm{H}_{01}$ & $\mathrm{H}_{02}$ & $H_{03}$ & $\mathrm{H}_{01}$ & $\mathrm{H}_{02}$ & $\mathrm{H}_{03}$ & $\mathrm{H}_{01}$ & $\mathrm{H}_{02}$ & $\mathrm{H}_{03}$ \\
\hline 12-REF & 0 & 100 & 0 & 34,90 & 64,94 & 0,16 & 100 & 0 & 0 & 100 & 0 & 0 & 100 & 0 & 0 \\
\hline 12-P.P20 & 0,16 & 64,94 & 34,90 & 0 & 100 & 0 & 100 & 0 & 0 & 98,06 & 1,89 & 0 & 63,28 & 36,68 & 0,04 \\
\hline 12-P.P40 & 0 & 0 & 100 & 0 & 0 & 100 & 0 & 100 & 0 & 0 & 0 & 100 & 0 & 0 & 100 \\
\hline 12-Р.P60 & 0 & 0 & 100 & 0 & 1,89 & 98,06 & 100 & 0 & 0 & 0 & 100 & 0 & 0,12 & 62,22 & 37,66 \\
\hline 12-P.P80 & 0 & 0 & 100 & 0,04 & 36,68 & 63,28 & 100 & 0 & 0 & 37,66 & 62,22 & 0,12 & 0 & 100 & 0 \\
\hline
\end{tabular}

Comparando a fila 3 (12-P.P40) com todas as colunas da hipótese nula $\mathrm{H}_{03}\left(\mathrm{u}_{1}>\mathrm{u}_{2}\right)$ pode-se notar que existe $100 \%$ de probabilidade de a hipótese não ser rejeitada. Logo, pode-se concluir que essa proporção de resíduo influenciou significativamente no comportamento mecânico do concreto devido a que a resistência à compressão desse concreto foi significativamente maior em referência aos outros concretos. Nota-se também que os concretos 12-REF e 12-P.P20 apresentaram 64,94\% de probabilidade de as resistências serem iguais $\left(H_{02}: u_{1}=u_{2}\right)$ e que os concretos 12-P.P60 e 12-P.P80 tiveram $62,22 \%$ de probabilidade de as resistências serem idênticas e 37,66\% de probabilidade de a resistência do teor de $60 \%$ ser maior do que a do teor de $80 \%$.

\subsubsection{Escolha da porcentagem ideal do pó de pedra no concreto}

Segundo os resultados obtidos na caracterização física do concreto no seu estado fresco e endurecido e dos resultados de resistência à compressão, conclui-se que a porcentagem ideal para a substituição da areia pelo pó de pedra no concreto é de $60 \%$ para os traços 1:15 e 1:10 e de 40\% para o traço 1:6. O fato de os exemplares com essas proporções terem obtido valores superiores nos ensaios pode ser explicado pelo melhor empacotamento proporcionado pela heterogeneidade granulométrica do resíduo. Desse modo, os vazios maiores foram preenchidos com partículas menores, cujos vazios foram novamente preenchidos com partículas ainda menores e assim sucessivamente. Esse efeito causou menor quantidade de vazios, menor porosidade, maior densidade, provocando um melhor comportamento físico e mecânico com relação aos outros concretos. 


\subsubsection{Corpos de prova com pó residual orgânico substituindo o cimento}

Como foi mencionado no Capítulo 3, foi avaliada a substituição de cimento por pó de resíduo orgânico com teores de 0\%,5\%,10\%, 15\%, 20\% para cada um dos traços (pobre, médio e rico). A Tabela 4.6 mostrou um resumo da nomenclatura utilizada para cada um dos corpos de prova em função do tipo de traço e dos teores de substituição. Essa terminologia é usada a seguir para cada um dos concretos. É importante destacar que todas as misturas, incluindo as de referência, foram produzidas com a porcentagem de pó de pedra que causou o melhor empacotamento dos agregados para cada um dos traços estudados, segundo as conclusões obtidas no item 5.4.1.4. Isso se deve a que o objetivo é produzir um bloco que apresente simultaneamente os dois tipos de pó residual estudados nesta pesquisa. Portanto, a partir da mistura com a porcentagem ideal de pó de pedra substituindo a areia foi feita a avaliação da proporção de pó de resíduo substituindo o cimento que causaria o melhor comportamento físico e mecânico do material.

\subsubsection{Propriedades físicas do concreto fresco}

Os ensaios realizados com o concreto fresco foram massa específica, teor de ar e coesão. Os resultados desses ensaios para o traço 1:15 ( $f_{b k}=4 \mathrm{MPa}$, pobre) encontram-se na Tabela 5.22. Os concretos foram feitos com $60 \%$ de pó de pedra substituindo a areia.

Tabela 5.22 - Propriedades físicas do concreto fresco com pó residual de resíduo orgânico para o traço 1:15 (Fonte: autor)

\begin{tabular}{|c|c|c|c|c|c|c|c|c|c|}
\hline \multirow{2}{*}{$\begin{array}{l}\text { Tipo de } \\
\text { CPs }\end{array}$} & \multicolumn{3}{|c|}{$\begin{array}{c}\text { Massa específica } \\
\text { fresca }\left(\mathbf{g} / \mathrm{cm}^{\mathbf{3}}\right)\end{array}$} & \multicolumn{3}{|c|}{ Teor de $\operatorname{ar}(\%)$} & \multicolumn{3}{|c|}{ Coesão $(\mathbf{k g})$} \\
\hline & Média & $\mathrm{Sd}$ & CV (\%) & Média & $\mathrm{Sd}$ & CV (\%) & Média & $\mathrm{Sd}$ & $\mathrm{CV}(\%)$ \\
\hline 4-REF & 2,18 & 0,023 & 1,05 & 8,93 & 0,41 & 4,59 & 7,10 & 0,06 & 0,88 \\
\hline 4-P.L5 & 2,17 & 0,029 & 1,34 & 8,95 & 0,52 & 6,81 & 7,06 & 0,09 & 1,27 \\
\hline 4-P.L10 & 2,15 & 0,026 & 1,21 & 9,14 & 0,39 & 4,36 & 6,97 & 0,07 & 0,99 \\
\hline 4-P.L15 & 2,16 & 0,021 & 0,99 & 9,17 & 0,37 & 4,76 & 6,42 & 0,05 & 0,82 \\
\hline 4-P.L20 & 2,11 & 0,028 & 1,36 & 9,21 & 0,45 & 5,09 & 6,13 & 0,07 & 1,11 \\
\hline
\end{tabular}

O exemplar sem adição de pó de resíduo orgânico obteve os melhores resultados nas propriedades físicas. Com relação aos concretos feitos com o resíduo substituindo o cimento, a proporção de 5\% apresentou o maior valor de massa específica, menor teor de ar e maior coesão.

A Tabela 5.23 mostra os resultados dos mesmos ensaios realizados com o concreto fresco para o traço 1:10 ( $\mathrm{f}_{\mathrm{bk}}=8 \mathrm{MPa}$, médio). Como já foi analisada anteriormente, $\mathrm{a}$ proporção ideal de pó de pedra para esse traço foi $60 \%$. 
Tabela 5.23 - Propriedades físicas do concreto fresco com pó residual de resíduo orgânico para o traço 1:10 (Fonte: autor)

\begin{tabular}{|c|c|c|c|c|c|c|c|c|c|}
\hline \multirow{2}{*}{$\begin{array}{l}\text { Tipo de } \\
\text { CPs }\end{array}$} & \multicolumn{3}{|c|}{$\begin{array}{c}\text { Massa específica } \\
\text { fresca }\left(\mathrm{g} / \mathrm{cm}^{3}\right)\end{array}$} & \multicolumn{3}{|c|}{ Teor de $\operatorname{ar}(\%)$} & \multicolumn{3}{|c|}{ Coesão (kg) } \\
\hline & Média & $\mathrm{Sd}$ & $\mathrm{CV}(\%)$ & Média & $\mathrm{Sd}$ & $\mathrm{CV}(\%)$ & Média & $\mathrm{Sd}$ & $\mathrm{CV}(\%)$ \\
\hline 8-REF & 2,23 & 0,04 & 1,80 & 6,42 & 0,41 & 6,38 & 8,11 & 0,30 & 3,70 \\
\hline 8-P.L5 & 2,25 & 0,04 & 1,86 & 5,34 & 0,38 & 7,11 & 8,62 & 0,28 & 3,25 \\
\hline 8-P.L10 & 2,22 & 0,04 & 1,76 & 6,41 & 0,40 & 6,24 & 8,34 & 0,34 & 4,07 \\
\hline 8-P.L15 & 2,20 & 0,04 & 1,61 & 6,53 & 0,46 & 7,04 & 8,07 & 0,35 & 4,33 \\
\hline 8-P.L20 & 2,17 & 0,04 & 1,91 & 6,74 & 0,39 & 5,78 & 8,02 & 0,31 & 3,86 \\
\hline
\end{tabular}

Dos concretos feitos com o resíduo, o 8-P.L5 teve maior valor de massa específica e de coesão e o menor valor de teor de ar com relação ao concreto de referência. Possivelmente, a porcentagem de $5 \%$ provocou uma pasta de cimento mais densa e menos porosa.

A Tabela 5.24 mostra os resultados do concreto fresco para o traço 1:6 $\left(\mathrm{f}_{\mathrm{bk}}=12 \mathrm{MPa}\right.$, rico). Para essa dosagem, as misturas foram feitas com $40 \%$ de pó de pedra substituindo a areia.

Tabela 5.24 - Propriedades físicas do concreto fresco com pó residual orgânico para o traço 1:6 (Fonte: autor)

\begin{tabular}{|c|c|c|c|c|c|c|c|c|c|}
\hline \multirow{2}{*}{$\begin{array}{l}\text { Tipo de } \\
\text { CPs }\end{array}$} & \multicolumn{3}{|c|}{$\begin{array}{l}\text { Massa específica } \\
\text { fresca }\left(\mathrm{g} / \mathrm{cm}^{3}\right)\end{array}$} & \multicolumn{3}{|c|}{ Teor de $\operatorname{ar}(\%)$} & \multicolumn{3}{|c|}{ Coesão (kg) } \\
\hline & Média & $\mathrm{Sd}$ & CV (\%) & & $\mathrm{Sd}$ & & & $\mathrm{Sd}$ & 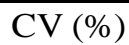 \\
\hline & 2,23 & 0,047 & & & & & 8 & 037 & \\
\hline & 2,25 & 0,041 & 1,8 & & 0, & & 11 & 0,35 & 2,48 \\
\hline 12-P.L10 & 2,23 & 0,046 & 2,03 & 5,40 & 0,34 & 6,29 & 14,14 & 0,32 & 2,26 \\
\hline 12-P.L15 & 2,21 & 0,051 & 2,30 & 5,43 & 0,32 & 5,89 & 14,07 & 0,41 & 2,91 \\
\hline 12-P.L20 & 2,20 & 0,048 & 2,24 & 5,48 & 0,39 & 7,11 & 13,84 & 0,36 & 2,60 \\
\hline
\end{tabular}

Para essa dosagem com maior consumo de cimento, os concretos com o resíduo apresentaram melhor comportamento físico com relação aos traços anteriores. As porcentagens de $5 \%$ e $10 \%$ alcançaram resultados de massa específica acima e iguais do exemplar de referência, respetivamente.

Segundo os resultados obtidos nos traços 1:10 e 1:6, pode-se inferir que o pó de resíduo orgânico atuou como fíler no concreto possibilitando o preenchimento dos vazios entre as partículas de cimento disperso, promovendo aumento na compacidade da mistura e, consequentemente, o refinamento dos poros. Esse mesmo comportamento foi encontrado também por Joudi-Bahri et al. (2012) quando substituíram parte do cimento por materiais mais finos. O resultado foi um concreto mais denso e com melhoria do vínculo pastaagregados. 
Quanto às propriedades físicas do concreto fresco, pode-se concluir que para o traço pobre (1:15) a substituição do cimento por pó de resíduo não apresentou resultados acima do concreto de referência. Já para o traço médio (1:10), a proporção de 5\% teve valores similares à mistura sem pó e para o traço de maior consumo de cimento (1:6), os concretos com 5\% e $10 \%$ obtiveram valores relativamente superiores ao concreto padrão.

\subsubsection{Propriedades físicas do concreto endurecido}

Os ensaios realizados para a caracterização física do concreto endurecido foram massa específica, absorção de água e índice de vazios. Os resultados desses ensaios para o traço 1:15 $\left(f_{b k}=4 \mathrm{MPa}\right.$, pobre) encontram-se na Tabela 5.25.

Tabela 5.25 -Propriedades físicas do concreto endurecido com pó residual de resíduo orgânico para o traço 1:15 (Fonte: autor)

\begin{tabular}{|c|c|c|c|c|c|c|c|c|c|}
\hline \multirow{2}{*}{$\begin{array}{l}\text { Tipo de } \\
\text { CPs }\end{array}$} & \multicolumn{3}{|c|}{$\begin{array}{l}\text { Massa específica } \\
\text { endurecida }\left(\mathrm{g} / \mathrm{cm}^{3}\right)\end{array}$} & \multicolumn{3}{|c|}{$\begin{array}{c}\text { Absorção de água } \\
(\%)\end{array}$} & \multicolumn{3}{|c|}{$\begin{array}{c}\text { Índice de vazios } \\
(\%)\end{array}$} \\
\hline & Média & $\mathrm{Sd}$ & $\mathrm{CV}(\%)$ & Média & $\mathrm{Sd}$ & $\mathrm{CV}(\%)$ & Média & $\mathrm{Sd}$ & $\mathrm{CV}(\%$ \\
\hline 4-REF & 2,71 & 0,034 & 1,26 & 6,39 & 0,27 & 4,2 & 10,86 & 0,56 & 5,21 \\
\hline & 2,69 & 0,028 & 1,06 & 6,42 & 0,32 & 4,9 & 10,82 & 0,52 & 4,80 \\
\hline 4-P.L10 & 2,66 & 0,032 & 1,19 & 6,47 & 0,25 & 3,86 & 10,69 & 0,59 & 5,52 \\
\hline 4-P & 2,62 & 0,036 & 1,36 & 6,54 & 0,31 & 4,7 & 9,98 & 0,57 & 5,71 \\
\hline 4-P.L20 & 2,59 & 0,033 & 1,30 & 6,61 & 0,36 & 5,44 & 9,75 & 0,61 & 6,25 \\
\hline
\end{tabular}

Na mistura endurecida, o pó residual orgânico não causou avanços nos resultados com relação ao concreto de referência, apresentando esse último maior valor de massa específica e menores valores de absorção de água e índice de vazios. Entre os exemplares feitos com pó de resíduo orgânico, a porcentagem de 5\% teve melhor comportamento nas propriedades físicas.

A Tabela 5.26 mostra os resultados dos ensaios para o traço 1:10 ( $\mathrm{f}_{\mathrm{bk}}=8 \mathrm{MPa}$, médio).

Tabela 5.26 - Propriedades físicas do concreto endurecido com pó residual orgânico para o traço 1:10 (Fonte: autor)

\begin{tabular}{|c|c|c|c|c|c|c|c|c|c|}
\hline \multirow{2}{*}{$\begin{array}{l}\text { Tipo de } \\
\text { CPs }\end{array}$} & \multicolumn{3}{|c|}{$\begin{array}{l}\text { Massa específica } \\
\text { endurecida }\left(\mathrm{g} / \mathrm{cm}^{3}\right)\end{array}$} & \multicolumn{3}{|c|}{$\begin{array}{c}\text { Absorção de água } \\
(\%)\end{array}$} & \multicolumn{3}{|c|}{$\begin{array}{c}\text { Índice de vazios } \\
(\%) \\
\end{array}$} \\
\hline & Média & $\mathrm{Sd}$ & $\overline{\mathrm{CV}(\%)}$ & Média & $\mathrm{Sd}$ & $\mathrm{CV}(\%)$ & Média & $\mathrm{Sd}$ & $\overline{\mathrm{CV}(\%)}$ \\
\hline 8-REF & 2,78 & 0,051 & 1,88 & 5,81 & 0,29 & 4,96 & 10,85 & 0,49 & 4,55 \\
\hline 8-P.L5 & 2,80 & 0,047 & 1,67 & 5,76 & 0,30 & 5,25 & 10,81 & 0,45 & 4,16 \\
\hline 8-P.L10 & 2,77 & 0,052 & 1,88 & 5,80 & 0,33 & 5,62 & 10,86 & 0,50 & 4,60 \\
\hline 8-P.L15 & 2,74 & 0,050 & 1,85 & 6,02 & 0,33 & 5,54 & 10,92 & 0,41 & 3,75 \\
\hline 8-P.L20 & 2,69 & 0,045 & 1,68 & 6,24 & 0,32 & 5,05 & 11,11 & 0,46 & 4,14 \\
\hline
\end{tabular}


Para essa dosagem, o concreto com $5 \%$ de pó orgânico teve maior valor de massa específica e menor valor de absorção e índice de vazios com relação ao concreto sem adição de pó.

Já a Tabela 5.27 mostra os resultados dos concretos estudados para o traço 1:6 $\left(\mathrm{f}_{\mathrm{bk}}=\right.$ $12 \mathrm{MPa}$, rico).

Tabela 5.27 - Propriedades físicas do concreto endurecido com pó residual de resíduo orgânico para o traço 1:6 (Fonte: autor)

\begin{tabular}{|c|c|c|c|c|c|c|c|c|c|}
\hline \multirow{2}{*}{$\begin{array}{l}\text { Tipo de } \\
\text { CPs }\end{array}$} & \multicolumn{3}{|c|}{$\begin{array}{l}\text { Massa específica } \\
\text { endurecida }\left(\mathrm{g} / \mathrm{cm}^{3}\right)\end{array}$} & \multicolumn{3}{|c|}{$\begin{array}{l}\text { Absorção de água } \\
(\%)\end{array}$} & \multicolumn{3}{|c|}{$\begin{array}{c}\text { Índice de vazios } \\
(\%)\end{array}$} \\
\hline & Média & $\mathrm{Sd}$ & $\mathrm{CV}(\%)$ & édia & $\mathrm{Sd}$ & $\mathrm{V}$ & Média & $\mathrm{Sd}$ & $\mathrm{CV}($ \\
\hline 12-REF & 2,81 & 0,051 & 1,82 & 5,01 & 0,28 & 5,58 & 9,98 & 0,4 & 4,72 \\
\hline 12-P.L5 & 2,84 & 0,052 & 1,83 & 4,96 & 0,31 & 6,2 & 9,86 & 0,4 & 4,9 \\
\hline 12-P.L10 & 2,82 & 0,049 & 1,75 & 4,98 & 0,29 & 5,82 & 9,89 & 0,42 & 4,25 \\
\hline 12-P.L15 & 2,78 & 0,055 & 1,99 & 5,09 & 0,32 & 6,28 & 10,08 & 0,46 & 4,56 \\
\hline 12-P.L20 & 2,75 & 0,047 & 1,76 & 5,15 & 0,27 & 5,24 & 10,67 & 0,50 & 4,68 \\
\hline
\end{tabular}

Para o traço de maior consumo de cimento, as porcentagens de substituição de $5 \%$ e $10 \%$ apresentaram os melhores valores das propriedades físicas. Para elas foram obtidas a maior massa específica e, consequentemente, a menor absorção de água e o menor índice de vazios, resultados obtidos pelo refinamento dos poros na pasta de cimento.

Segundo os resultados obtidos nos traços 1:10 e 1:6, várias pesquisas, como Lagerblad e Vogt (2008), Vogt (2010) e Elyamany et al,.(2014) comprovaram que o uso de materiais de enchimento substituindo parte do cimento trazem melhorias nas propriedades físicas do concreto endurecido, como maior massa específica e menor índice de vazios devido ao melhor empacotamento na mistura.

Com relação às propriedades físicas do concreto endurecido, à semelhança do ocorrido com o concreto fresco, pode-se concluir que, para o traço pobre (1:15), a substituição do cimento por pó de resíduo orgânico não apresentou resultados acima do concreto de referência. Já para o traço médio (1:10), a proporção de 5\% teve valores similares à mistura sem pó e para o traço de maior consumo de cimento (1:6), os concretos com $5 \%$ e $10 \%$ obtiveram valores superiores ao concreto de referência.

\subsubsection{Resistência à compressão dos corpos de prova com pó residual orgânico}

A mesma análise feita para a resistência à compressão dos corpos de prova com pó de pedra foi realizada para o concreto com as diferentes porcentagens de pó residual orgânico. 
Dessa forma, são apresentados os valores por meio dos intervalos de confiança, os diagramas de caixa e as análises da diferença entre duas médias usando a técnica do Bootstrap.

\section{$\underline{\text { Traco 1:15 }}$}

A Tabela 5.28 mostra os intervalos de confiança da média, desvio padrão e coeficiente de variação da resistência à compressão da população dos concretos para uma confiabilidade de $95 \%$ do traço 1:15.

Tabela 5.28 - Resistência à compressão do concreto com pó de resíduo orgânico para o traço 1:15 (Fonte: autor)

\begin{tabular}{|c|c|c|c|c|c|c|}
\hline \multirow{3}{*}{$\begin{array}{l}\text { Tipo de } \\
\text { CPs }\end{array}$} & \multicolumn{6}{|c|}{ Resistência à compressão (MPa) } \\
\hline & \multirow{2}{*}{\multicolumn{2}{|c|}{$\begin{array}{c}\text { Média } \\
\text { Inferior Superior }\end{array}$}} & \multirow{2}{*}{\multicolumn{2}{|c|}{$\frac{\text { Sd }}{\text { Inferior Superior }}$}} & \multicolumn{2}{|c|}{ CV (\%) } \\
\hline & & & & & Inferior & Superior \\
\hline 4-REF & 21,64 & 22,42 & 0,30 & 0,81 & 1,38 & 3,61 \\
\hline 4-P.L5 & 20,01 & 21,25 & 0,53 & 1,22 & 2,64 & 5,74 \\
\hline 4-P.L10 & 15,82 & 17,04 & 0,57 & 1,25 & 3,60 & 7,33 \\
\hline 4-P.L15 & 10,97 & 12,03 & 0,49 & 1,10 & 4,46 & 9,14 \\
\hline 4-P.L20 & 2,53 & 3,57 & 0,41 & 0,97 & 16,20 & 27,17 \\
\hline
\end{tabular}

Pode-se notar que o intervalo de valores mais alto corresponde ao concreto de referência, que teve $60 \%$ de pó de pedra substituindo a areia e $0 \%$ do pó de resíduo. No que concerne aos concretos feitos com o resíduo substituindo o cimento, a proporção de 5\% apresentou o maior valor de resistência à compressão. Segundo os intervalos do desvio padrão, os valores foram inferiores a $2 \mathrm{MPa}$, portanto não existe evidência de dispersão dos resultados devido a um correto controle no processo de produção do concreto.

Comparando de forma prática os resultados dos cinco grupos de concreto, na Figura 5.9 é mostrado o diagrama de caixa dos valores médios da resistência à compressão. 


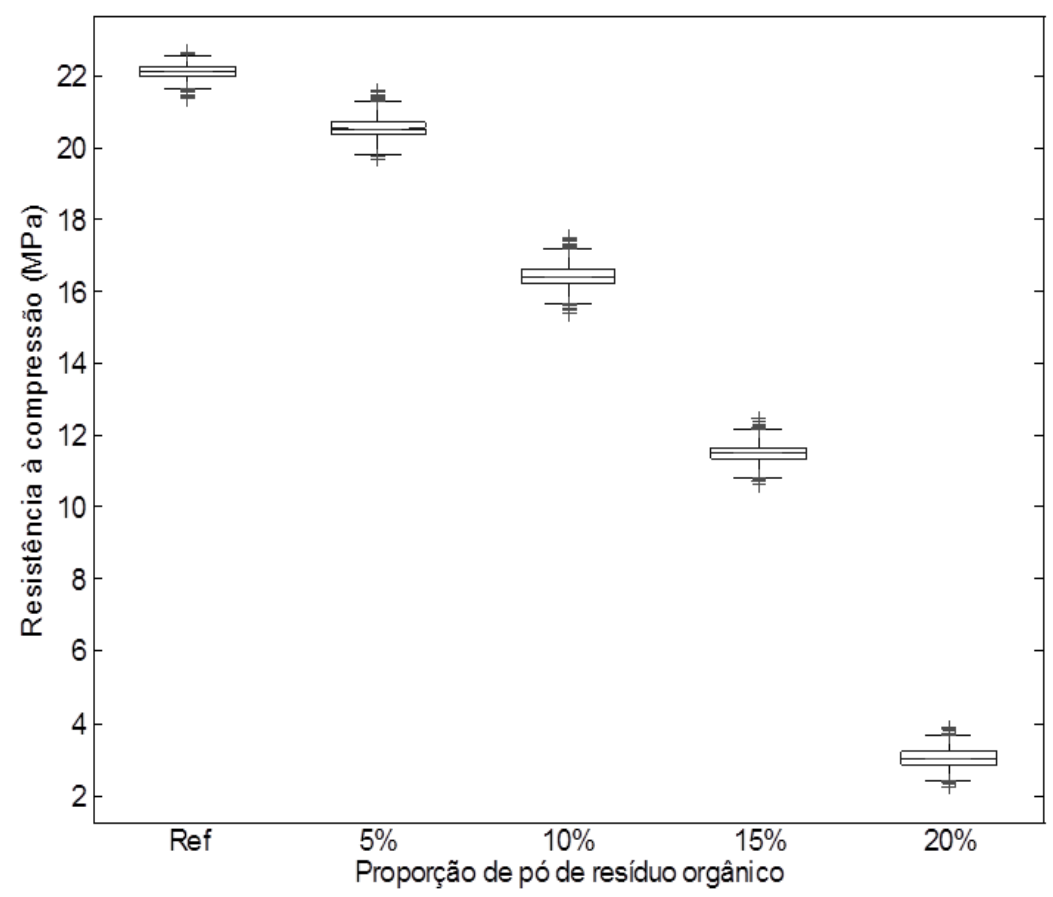

Figura 5.9 - Diagrama de caixa para os dados da resistência à compressão do concreto com pó residual orgânico para o traço 1:15 (Fonte: autor)

A resistência dos concretos feitos com o resíduo orgânico não superou a do concreto padrão. Portanto, pode-se dizer que o pó residual não apresenta propriedades aglomerantes e que a diminuição da quantidade do cimento efetivamente piorou as propriedades resistentes do concreto.

A Tabela 5.29 mostra a probabilidade de aceitação das hipóteses nulas da resistência média à compressão sempre entre duas populações, uma localizada nas filas e a outra nas colunas.

Tabela 5.29 - Probabilidade de que as hipóteses nulas sejam aceitas para o concreto com pó residual orgânico para o traço 1:15 (Fonte: autor)

\begin{tabular}{|c|c|c|c|c|c|c|c|c|c|c|c|c|c|c|c|}
\hline \multirow{2}{*}{$\begin{array}{l}\text { Tipo de } \\
\text { concreto }\end{array}$} & \multicolumn{3}{|c|}{ 4-REF } & \multicolumn{3}{|c|}{ 4-P.L5 } & \multicolumn{3}{|c|}{ 4-P.L10 } & \multicolumn{3}{|c|}{ 4-P.L15 } & \multicolumn{3}{|c|}{ 4-P.L20 } \\
\hline & $\mathbf{H}_{01}$ & $\mathbf{H}_{02}$ & $\mathbf{H}_{03}$ & $\mathbf{H}_{01}$ & $\mathbf{H}_{02}$ & $\mathbf{H}_{03}$ & $\mathbf{H}_{01}$ & $\mathbf{H}_{02}$ & $\mathbf{H}_{\mathbf{0 3}}$ & $\mathbf{H}_{01}$ & $\mathbf{H}_{02}$ & $\mathbf{H}_{03}$ & $\mathbf{H}_{01}$ & $\mathbf{H}_{02}$ & $\mathbf{H}_{03}$ \\
\hline 4-REF & 0 & 100 & 0 & 0 & 5,23 & 94,77 & 0 & 0 & 100 & 0 & 0 & 100 & 0 & 0 & 100 \\
\hline 4-P.L5 & 94,77 & 5,23 & 0 & 0 & 100 & 0 & 0 & 0 & 100 & 0 & 0 & 100 & 0 & 0 & 100 \\
\hline 4-P.L10 & 100 & 0 & 0 & 100 & 0 & 0 & 0 & 100 & 0 & 0 & 0 & 100 & 0 & 0 & 100 \\
\hline 4-P.L15 & 100 & 0 & 0 & 100 & 0 & 0 & 100 & 0 & 0 & 0 & 100 & 0 & 0 & 0 & 100 \\
\hline 4-P.L20 & 100 & 0 & 0 & 100 & 0 & 0 & 100 & 0 & 0 & 100 & 0 & 0 & 0 & 100 & 0 \\
\hline
\end{tabular}

Existe evidência estatística que o concreto sem adição do pó de resíduo orgânico alcançou os maiores valores médios de resistência à compressão com relação aos concretos com adição desse resíduo. Para a comparação envolvendo os exemplares 4-REF (fila 1) e 4P.L5 (coluna 2) pode-se afirmar que existe 5,23\% de probabilidade de que as resistências 
sejam iguais $\left(\mathrm{H}_{02}: \mathrm{u}_{1}=\mathrm{u}_{2}\right)$ e $94,77 \%$ de que a resistência do concreto de referência seja superior $\left(\mathrm{H}_{03}: \mathrm{u}_{1}>\mathrm{u}_{2}\right)$.

\section{$\underline{\text { Traco 1:10 }}$}

Para essa dosagem de concreto, a Tabela 5.30 mostra os intervalos de confiança da média, desvio padrão e coeficiente de variação da resistência à compressão da população para uma confiabilidade de $95 \%$.

Tabela 5.30 - Resistência à compressão do concreto com pó de resíduo orgânico para o traço 1:10 (Fonte: autor)

\begin{tabular}{|c|c|c|c|c|c|c|}
\hline \multirow{3}{*}{$\begin{array}{c}\text { Tipo de } \\
\text { CPs }\end{array}$} & \multicolumn{6}{|c|}{ Resistência à compressão (MPa) } \\
\hline & \multirow{2}{*}{\multicolumn{2}{|c|}{$\frac{\text { Média }}{\text { Inferior Superior }}$}} & \multirow{2}{*}{\multicolumn{2}{|c|}{$\begin{array}{c}\text { Sd } \\
\text { Inferior Superior }\end{array}$}} & \multicolumn{2}{|c|}{ CV $(\%)$} \\
\hline & & & & & Inferior & Superior \\
\hline 8-REF & 32,66 & 33,92 & 0,65 & 1,17 & 1,97 & 3,41 \\
\hline 8-P.L5 & 33,69 & 34,98 & 0,51 & 1,33 & 1,51 & 3,80 \\
\hline 8-P.L10 & 27,40 & 28,95 & 0,66 & 1,60 & 2,40 & 5,52 \\
\hline 8-P.L15 & 19,31 & 20,63 & 0,63 & 1,17 & 3,26 & 5,67 \\
\hline 8-P.L20 & 9,54 & 10,93 & 0,47 & 1,24 & 4,92 & 11,34 \\
\hline
\end{tabular}

No traço médio, o concreto com $5 \%$ de pó de resíduo orgânico alcançou resultados acima do exemplar de referência. A utilização de teores maiores de 5\% não apresentou resultados satisfatórios, sendo a resistência inferior ao concreto sem pó do resíduo orgânico.

O diagrama de caixa dos valores médios da resistência de cada um dos concretos é mostrado na Figura 5.10. 


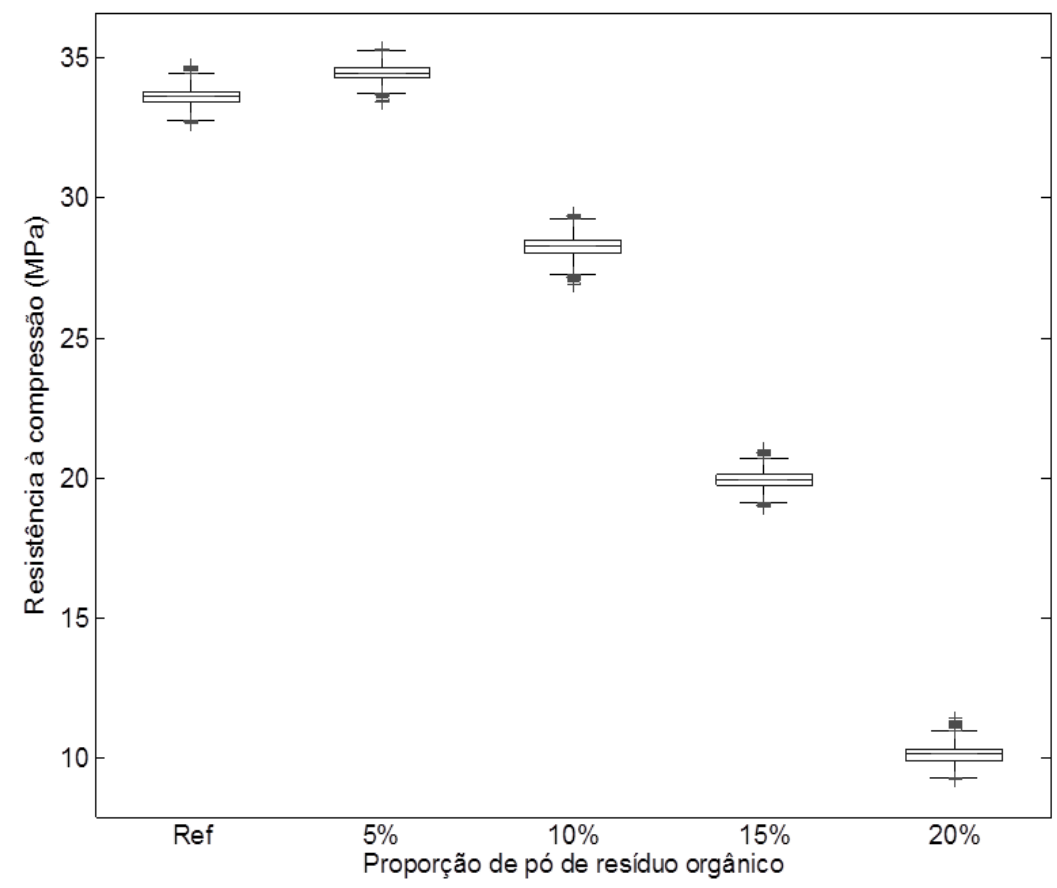

Figura 5.10 - Diagrama de caixa para os dados da resistência à compressão do concreto com pó residual orgânico para o traço 1:10 (Fonte: autor)

A adição de $5 \%$ de pó residual orgânico substituindo o cimento melhorou a pasta diminuindo a dimensão e quantidade de poros. O resultado é um concreto mais resistente e com menor porosidade. De forma geral, os dados dos cinco grupos apresentaram uma distribuição simétrica e não existe evidência de dispersão dos mesmos, sob o aspecto visual.

Para uma confirmação estatística da afirmação anterior é apresentada a Tabela 5.31, a qual mostra a porcentagem de probabilidade de que as hipóteses nulas sejam aceitas.

Tabela 5.31 - Probabilidade de que as hipóteses nulas sejam aceitas para o concreto com pó de resíduo orgânico para o traço 1:10 (Fonte: autor)

\begin{tabular}{|c|c|c|c|c|c|c|c|c|c|c|c|c|c|c|c|}
\hline \multirow{2}{*}{$\begin{array}{c}\text { Tipo de } \\
\text { concreto }\end{array}$} & \multicolumn{3}{|c|}{ 8-REF } & \multicolumn{3}{|c|}{ 8-P.L5 } & \multicolumn{3}{|c|}{ 8-P.L10 } & \multicolumn{3}{|c|}{ 8-P.L15 } & \multicolumn{3}{|c|}{ 8-P.L20 } \\
\hline & $\mathrm{H}_{01}$ & $\mathrm{H}_{02}$ & $\mathrm{H}_{03}$ & $\mathrm{H}_{01}$ & $\mathrm{H}_{02}$ & $\mathrm{H}_{03}$ & $\mathrm{H}_{01}$ & $\mathrm{H}_{02}$ & $\mathrm{H}_{03}$ & $\mathrm{H}_{01}$ & $\mathrm{H}_{02}$ & $\mathrm{H}_{03}$ & & $\mathrm{H}_{02} \mathrm{H}$ & $\mathrm{H}_{03}$ \\
\hline 8-REI & 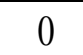 & 100 & 0 & 54,22 & 45,75 & 0,03 & 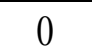 & 0 & 10 & 0 & & 10 & 0 & $\begin{array}{ll}0 & 1\end{array}$ & 100 \\
\hline 8-P.I & 0,03 & 45,75 & 54,22 & 0 & 100 & 0 & & & 10 & & & & & 0 & \\
\hline -P.L1 & 100 & 0 & 0 & 10 & 0 & ( & & 100 & & & 0 & 100 & 0 & $\begin{array}{ll}0 & 1\end{array}$ & \\
\hline P.L & 100 & 0 & 0 & 100 & ( & 0 & 100 & 0 & & & 100 & 0 & 0 & $\begin{array}{ll}0 & 1\end{array}$ & 100 \\
\hline P.L20 & 100 & 0 & 0 & 100 & 0 & 0 & 100 & 0 & 0 & 100 & 0 & 0 & 0 & 100 & 0 \\
\hline
\end{tabular}

Comparando-se a fila 2 (8-P.L5) com as primeiras colunas correspondentes ao concreto 8-REF pode-se dizer que existe $54,22 \%$ de probabilidade de que a resistência do concreto com $5 \%$ de pó de resíduo seja superior ao concreto de referência, $45,75 \%$ que sejam iguais e só $0,03 \%$ que seja menor. Á vista disso, pode-se concluir que o concreto modificado com $5 \%$ de 
pó teve o melhor comportamento mecânico não somente com relação ao concreto padrão, senão também com relação aos exemplares feitos com as porcentagens de $10 \%, 15 \%$ e $20 \%$. Isso é notado quando é feita a análise da fila 2 com as coluna 3, 4 e 5 correspondentes a esses exemplares, na qual pode ser observado que a hipótese nula $\mathrm{H}_{03}\left(\mathrm{u}_{1}>\mathrm{u}_{2}\right)$ apresenta $100 \%$ de probabilidade de a resistência ser estatisticamente superior.

Já comparando o concreto de referência e as misturas com as porcentagens de 10\%,15\% e $20 \%$ pode-se dizer que existe diferença na resistência à compressão, sendo a do concreto padrão estatisticamente maior.

\section{$\underline{\text { Traco 1:6 }}$}

A Tabela 5.32 mostra os intervalos de confiança da média, desvio padrão e coeficiente de variação da resistência à compressão da população para uma confiabilidade de $95 \%$ para o traço 1:6.

Tabela 5.32 - Resistência à compressão do concreto com pó de resíduo orgânico para o traço 1:6 (Fonte: autor)

\begin{tabular}{|c|c|c|c|c|c|c|}
\hline \multirow{3}{*}{$\begin{array}{l}\text { Tipo de } \\
\text { CPs }\end{array}$} & \multicolumn{6}{|c|}{ Resistência à compressão (MPa) } \\
\hline & \multirow{2}{*}{\multicolumn{2}{|c|}{$\begin{array}{c}\text { Média } \\
\text { Inferior Superior }\end{array}$}} & \multirow{2}{*}{\multicolumn{2}{|c|}{$\begin{array}{c}\text { Sd } \\
\text { Inferior Superior }\end{array}$}} & \multirow{2}{*}{\multicolumn{2}{|c|}{$\begin{array}{c}\text { CV }(\%) \\
\text { Inferior Superior }\end{array}$}} \\
\hline & & & & & & \\
\hline 12-REF & 49,57 & 51,27 & 0,46 & 1,69 & 0,93 & 3,29 \\
\hline 12-P.L5 & 56,64 & 58,09 & 0,59 & 1,67 & 1,04 & 2,87 \\
\hline 12-P.L10 & 56,59 & 57,88 & 0,61 & 1,23 & 1,07 & 2,12 \\
\hline 12-P.L15 & 34,35 & 35,77 & 0,54 & 1,40 & 1,57 & 3,91 \\
\hline 12-P.L20 & 20,15 & 21,52 & 0,64 & 1,21 & 3,17 & 5,62 \\
\hline
\end{tabular}

$\mathrm{Na}$ dosagem com maior consumo de cimento, os concretos produzidos com 5\% e $10 \%$ do pó residual tiveram maiores valores de resistência com relação ao concreto de referência. Já para as porcentagens de $15 \%$ e $20 \%$, a resistência diminuiu consideravelmente.

Para uma melhor visualização dos resultados é mostrado na Figura 5.11 o diagrama de caixa dos valores médios da resistência de cada um dos concretos. 


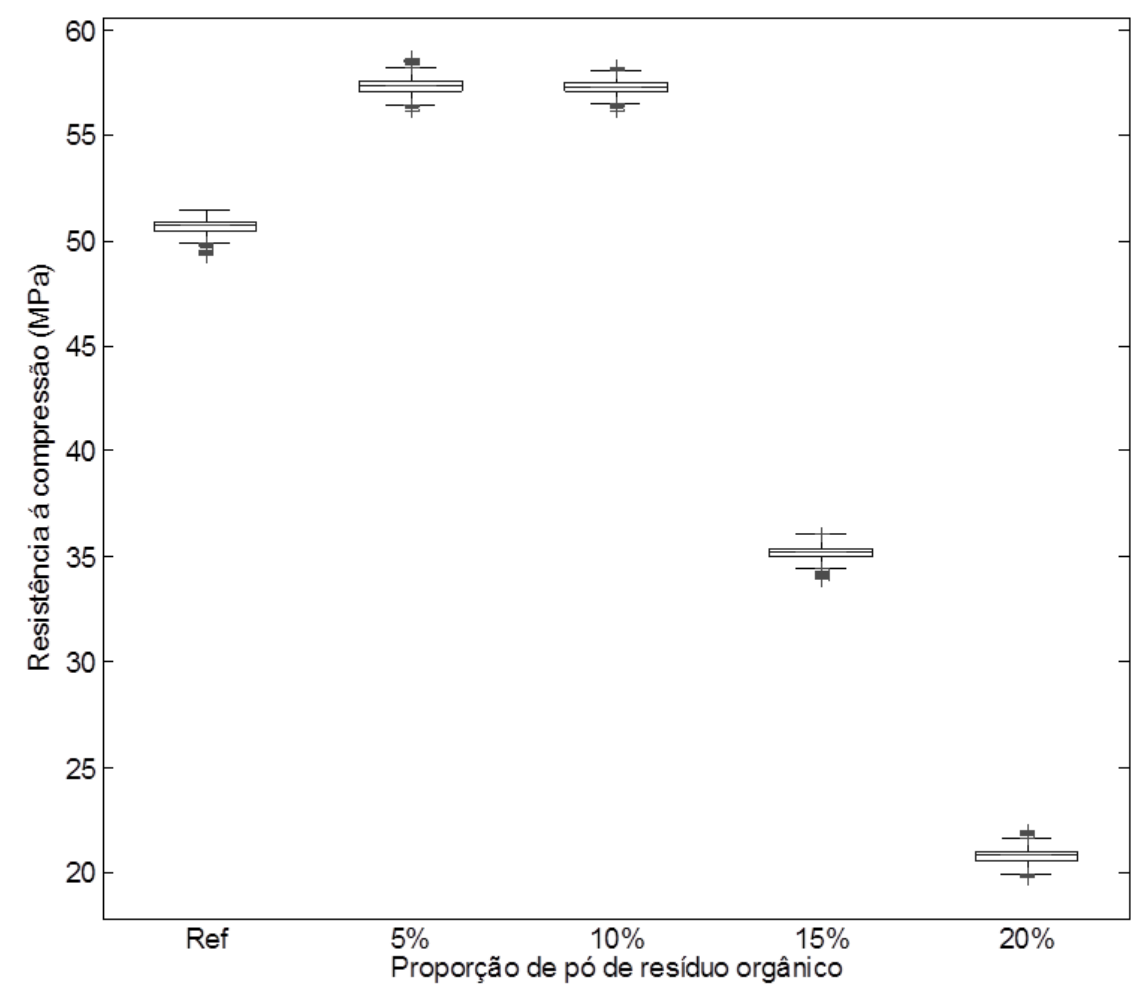

Figura 5.11 - Diagrama de caixa para os dados da resistência à compressão do concreto com pó residual orgânico do traço 1:6 (Fonte: autor)

O fato de os teores de $5 \%$ e $10 \%$ com pó derivado de resíduos orgânicos ter provocado maior resistência pode dever-se à obtenção de um concreto mais denso e menos poroso.

A Tabela 5.33 mostra a análise estatística da diferença das médias da resistência à compressão entre duas populações de concreto.

Tabela 5.33 - Probabilidade de que as hipóteses nulas sejam aceitas para o concreto com pó de resíduo orgânico para o traço 1:6 (Fonte: autor)

\begin{tabular}{|c|c|c|c|c|c|c|c|c|c|c|c|c|c|c|c|}
\hline \multirow{2}{*}{$\begin{array}{l}\text { Tipo de } \\
\text { concreto }\end{array}$} & \multicolumn{3}{|c|}{ 12-REF } & \multicolumn{3}{|c|}{ 12-P.L5 } & \multicolumn{3}{|c|}{ 12-P.L10 } & \multicolumn{3}{|c|}{ 12-P.L15 } & \multicolumn{3}{|c|}{ 12-P.L20 } \\
\hline & $\mathbf{H}_{01}$ & $\mathbf{H}_{02}$ & $\mathbf{H}_{03}$ & $\mathbf{H}_{01}$ & $\mathbf{H}_{02}$ & $\mathbf{H}_{03}$ & $\mathbf{H}_{01}$ & $\mathbf{H}_{02}$ & $\mathbf{H}_{03}$ & $\mathbf{H}_{01}$ & $\mathbf{H}_{02}$ & $\mathbf{H}_{03}$ & $\mathbf{H}_{01}$ & $\mathbf{H}_{02}$ & $\mathbf{H}_{\mathbf{0 3}}$ \\
\hline 12-REF & 0 & 100 & 0 & 100 & 0 & 0 & 100 & 0 & 0 & 0 & 0 & 100 & 0 & 0 & 100 \\
\hline 12-P.L5 & 0 & 0 & 100 & 0 & 100 & 0 & 0,05 & 99,79 & 0,16 & 0 & 0 & 100 & 0 & 0 & 100 \\
\hline 12-P.L10 & 0 & 0 & 100 & 0,16 & 99,79 & 0,05 & 0 & 100 & 0 & 0 & 0 & 100 & 0 & 0 & 100 \\
\hline 12-P.L15 & 100 & 0 & 0 & 100 & 0 & 0 & 100 & 0 & 0 & 0 & 100 & 0 & 0 & 0 & 100 \\
\hline 12-P.L20 & 100 & 0 & 0 & 100 & 0 & 0 & 100 & 0 & 0 & 100 & 0 & 0 & 0 & 100 & 0 \\
\hline
\end{tabular}

Segundo os dados da Tabela 5.33, os concretos com as porcentagens 5\% e 10\% apresentaram $100 \%$ de probabilidade de a resistência à compressão ser estatisticamente maior com relação ao concreto de referência. Isso pode ser comprovado comparando-se os valores correspondentes às filas 2 e 3 com a coluna da hipótese nula $\mathrm{H}_{03}$ relacionada ao concreto 12Ref. Já com relação aos concretos 12-P.L5 e 12-P.L10, existe 99,79\% de probabilidade de que 
a hipótese nula $\mathrm{H}_{02}\left(\mathrm{u}_{1}=\mathrm{u}_{2}\right)$ seja aceita, portanto, ambas resistências são muito parecidas. Dessa forma fica comprovado que as porcentagem de $5 \%$ e $10 \%$ influenciaram significativamente no desempenho mecânico do concreto, contribuindo para a obtenção de misturas mais resistentes.

\subsubsection{Escolha da porcentagem ideal do pó residual orgânico no concreto}

O pó residual orgânico apresentou diferente comportamento em função do tipo de traço empregado. Nos concretos com menor consumo de cimento e maior conteúdo de agregados (traço 1:15), tem-se maior área superficial de agregados e, portanto, mais zonas de interface. Possivelmente, a proporção de cimento junto a cada uma das porcentagens estudadas de pó não permitiu o correto empacotamento da mistura. É por essa razão que o concreto de referência teve melhor comportamento nos ensaios realizados. Para o traço médio (1:10), a porcentagem de 5\% substituindo o cimento pelo resíduo apresentou maior massa específica e maior resistência à compressão com relação ao concreto de referência. Já para o traço de maior consumo de cimento e menor conteúdo de agregados (1:6), as proporções $5 \%$ e $10 \%$ apresentaram os melhores resultados nos ensaios realizados. Isso mostra o correto empacotamento provocado pelo pó orgânico para essas proporções, preenchendo os vazios do material e refinando os poros da pasta de cimento. $\mathrm{O}$ resultado foi um concreto mais denso, com menor absorção, menor índice de vazios e maior resistência à compressão. Esse mesmo comportamento foi encontrado por Rebmann (2011) na sua pesquisa sobre concretos de baixo consumo de cimento. Com base em conceitos de empacotamento de agregados e o uso de fílers na pasta de cimento obtiveram-se concretos de alta resistência com redução do cimento até $30 \%$. 


\section{RESULTADOS E DISCUSSÕES: BLOCOS E ELEMENTOS DE ALVENARIA ESTRUTURAL}

Neste capítulo é estudado o comportamento mecânico dos blocos, prismas e pequenas paredes produzidos com a adição de pós residuais e fibra de sisal. De forma semelhante a outras análises realizadas neste trabalho, neste capítulo também foi utilizada a técnica do Bootstrap para realizar um estudo estatístico nos resultados de resistência à compressão dos blocos e elementos.

\subsection{Nomenclatura adotada para os blocos}

Diferentes séries de blocos foram produzidas as quais foram caracterizadas pela adição dos pós residuais substituindo o cimento e a areia, segundo os resultados obtidos nos ensaios dos corpos de prova. Também foram fabricados blocos com adição da fibra de sisal para avaliar o comportamento do reforço na alvenaria estrutural, além da durabilidade da fibra no concreto. Como já foi mencionado no item 4.12, dois tipos de blocos reforçados com sisal foram produzidos, o primeiro foi feito com o cimento Portland CP V-ARI RS, e o segundo com o cimento CP III-40 RS e adição de $10 \%$ de sílica ativa com relação ao volume do cimento. Essas duas séries foram comparadas com os blocos de referência sem adição da fibra. $\mathrm{O}$ traço escolhido para as misturas com e sem adição do sisal foi 1:10. Com relação às séries com adição do pó de resíduo orgânico, os blocos foram produzidos com a porcentagem do resíduo que provocou o melhor comportamento no concreto em cada traço e foram comparados com as unidades de referência sem adição do pó residual. É importante destacar que todas as misturas, incluindo as de referência, foram produzidas com a porcentagem de pó de pedra que causou o melhor empacotamento dos agregados em cada um dos traços. A Tabela 6.1 apresenta a terminologia adotada para os blocos, assim como as características de cada grupo. 
Tabela 6.1 - Terminologia e características de cada série de blocos (Fonte: autor)

\begin{tabular}{|c|c|}
\hline Série & $\mathrm{Ca}$ \\
\hline BE1:1 & $\begin{array}{l}\text { Bloco de referência do traço } 1: 15 \text { e fbk }=4 \mathrm{MPa} \text { com } 60 \% \text { de pó } \\
\text { de pedra substituindo areia e sem adição do pó de lixo }\end{array}$ \\
\hline BE1:15-5\%P.L & $\begin{array}{l}\text { Bloco do traço } 1: 15 \text { e } \mathrm{f}_{\mathrm{bk}}=4 \mathrm{MPa} \text { com } 60 \% \text { de pó de pedra } \\
\text { substituindo areia e } 5 \% \text { de pó de lixo substituindo o cimento }\end{array}$ \\
\hline BE1 & $\begin{array}{l}\text { Bloco de referência do traço 1:10 e } \mathrm{f}_{\mathrm{bk}}=8 \mathrm{MPa} \text { com } 60 \% \text { de pó } \\
\text { de pedra substituindo areia e sem adição do pó de lixo e do sisal }\end{array}$ \\
\hline oP.L & $\begin{array}{l}\text { Bloco do traço } 1: 10 \text { e } \mathrm{f}_{\mathrm{bk}}=8 \mathrm{MPa} \text { com } 60 \% \text { de pó de pedra } \\
\text { substituindo areia e } 5 \% \text { de pó de lixo substituindo o cimento }\end{array}$ \\
\hline BE1 & $\begin{array}{l}\text { e teor de } 1 \% \text { sem } \\
\text { d CP V-ARI } \\
\text { e teor de } 1 \% \text { com a }\end{array}$ \\
\hline BE1 & $\begin{array}{l}\text { matriz modificada utilizando cimento Portland CP III e } 10 \% \text { de } \\
\text { silica ativa }\end{array}$ \\
\hline BE1:6-Ref & $\begin{array}{l}\text { Bloco de referência do traço } 1: 6 \text { e } \mathrm{f}_{\mathrm{bk}}=12 \mathrm{MPa} \text { com } 40 \% \text { de pó } \\
\text { de pedra substituindo areia e sem adição do pó de lixo }\end{array}$ \\
\hline BE1:6-10\%P.L & $\begin{array}{l}\text { Bloco do traço } 1: 6 \text { e } \mathrm{f}_{\mathrm{bk}}=12 \mathrm{MPa} \text { com } 40 \% \text { de pó de pedra } \\
\text { substituindo areia e } 10 \% \text { de pó de lixo substituindo o cimento }\end{array}$ \\
\hline
\end{tabular}

\subsection{Propriedades geométricas dos blocos}

\subsubsection{Análise dimensional}

As dimensões dos blocos e meio-blocos estruturais estabelecidas pelos códigos normativos são condições essenciais para um correto desempenho das unidades. Dessa forma poderá ser evitado o surgimento de futuras patologias. É por essa razão que todas as unidades produzidas com os materiais não convencionais têm que obedecer a esses limites.

A Tabela C 1, no Apêndice C mostra a média das leituras realizadas em cada série de blocos para medir a largura, o comprimento e a altura real e os valores de tolerância estabelecidos pela NBR 6136: 2014. A

Tabela C 2 apresenta as dimensões para os meio-blocos. Todos os blocos com dimensões nominais de $140 \mathrm{~mm}$ x $190 \mathrm{~mm}$ x $390 \mathrm{~mm}$ (largura, altura, comprimento) e todos os meio-blocos com dimensões nominais de $140 \mathrm{~mm}$ x $190 \mathrm{~mm}$ x $190 \mathrm{~mm}$ satisfizeram os requisitos dimensionais da NBR 6136: 2014.

O bloco de concreto possuía furos tronco-cônicos, ou seja, as espessuras das paredes variavam ao longo de sua altura. Assim, foram determinadas as dimensões das paredes longitudinais e transversais na face de menor espessura (face inferior no momento do assentamento). As espessuras reais das paredes dos blocos são apresentadas na Tabela C 3. 
Nota-se que as medidas apresentaram valores médios superiores aos mínimos prescritos pela NBR 6136: 2014, cumprindo as exigências da norma.

Com relação à dimensão dos furos dos blocos, a NBR 6136: 2014 estabelece que o menor diâmetro deve ser maior que $70 \mathrm{~mm}$. A Tabela C 4 mostra que os blocos fabricados cumprem com esse requisito.

\subsection{2. Área bruta e área líquida}

As áreas bruta e líquida para cada um das séries dos blocos avaliados, assim como a relação entre área líquida e área bruta são apresentadas na Tabela 6.2.

Tabela 6.2 - Valores de área bruta e líquida dos blocos (Fonte: autor)

\begin{tabular}{|c|c|c|c|c|c|c|c|}
\hline \multirow{2}{*}{ Tipo de Bloco } & \multicolumn{3}{|c|}{ Área bruta $\left(\mathrm{mm}^{2}\right)$} & \multicolumn{3}{|c|}{ Área líquida $\left(\mathrm{mm}^{2}\right)$} & \multirow{2}{*}{$\mathrm{A}_{\mathrm{liq}} / \mathrm{A}_{\mathrm{br}}(\%)$} \\
\hline & Média & $S_{d}$ & C.V (\%) & Média & $S_{d}$ & C.V (\%) & \\
\hline BE1:15-Ref & 54471,50 & 382,92 & 0,70 & 30182,66 & 338,05 & 1,12 & 55,41 \\
\hline BE1:15-5\%P.L & 55050,40 & 445,91 & 0,81 & 31053,93 & 322,96 & 1,04 & 56,41 \\
\hline BE1:10-Ref & 54117,80 & 362,59 & 0,67 & 30203,14 & 289,95 & 0,96 & 55,81 \\
\hline BE1:10-5\%P.L & 54326,00 & 254,37 & 0,47 & 30265,01 & 269,36 & 0,89 & 55,71 \\
\hline BE1:10-F1 & 54328,11 & 227,59 & 0,42 & 30679,08 & 279,18 & 0,91 & 56,47 \\
\hline BE1:10-F2 & 54378,20 & 413,27 & 0,76 & 30457,23 & 231,47 & 0,76 & 56,01 \\
\hline BE1:6-Ref & 54412,10 & 271,20 & 0,50 & 31194,46 & 327,54 & 1,05 & 57,33 \\
\hline BE1:6-10\%P.L & 54626,10 & 295,30 & 0,54 & 30694,41 & 297,74 & 0,97 & 56,19 \\
\hline
\end{tabular}

Os blocos apresentaram valores de área líquida muito parecidos, uma vez que foram produzidas na mesma máquina com o mesmo molde. Como a razão entre a área líquida e a área bruta dos blocos apresentou valor médio menor do que $75 \%$, os mesmos foram classificados como blocos vazados segundo a NBR 6136: 2014.

\subsection{Propriedades físicas dos blocos}

\subsubsection{Massa específica}

\subsubsection{Blocos produzidos com os pós residuais}

Na Tabela 6.3 encontram-se os resultados das massas específicas seca ao ar e saturada para cada série de bloco fabricadas com os pós residuais. 
Tabela 6.3 - Massa específica dos blocos produzidos com os pós residuais (Fonte: autor)

\begin{tabular}{|c|c|c|c|c|c|c|}
\hline \multirow[t]{2}{*}{ Tipo de Bloco } & \multicolumn{3}{|c|}{$\begin{array}{l}\text { Massa específica } \\
\text { seca ao ar }\left(\mathrm{g} / \mathrm{cm}^{3}\right)\end{array}$} & \multicolumn{3}{|c|}{$\begin{array}{c}\text { Massa específica } \\
\text { saturada }\left(\mathrm{g} / \mathrm{cm}^{3}\right)\end{array}$} \\
\hline & Média & $S_{d}$ & C.V (\%) & Média & $\mathbf{S}_{\mathrm{d}}$ & C.V (\%) \\
\hline BE1:15-Ref & 2,35 & 0,02 & 0,68 & 2,43 & 0,02 & 0,64 \\
\hline BE1:15-5\%P.L & 2,34 & 0,01 & 0,43 & 2,42 & 0,01 & 0,41 \\
\hline BE1:10-Ref & 2,41 & 0,02 & 0,83 & 2,48 & 0,02 & 0,81 \\
\hline BE1:10-5\%P.L & 2,42 & 0,02 & 0,94 & 2,50 & 0,01 & 0,40 \\
\hline BE1:6-Ref & 2,45 & 0,01 & 0,41 & 2,51 & 0,01 & 0,40 \\
\hline BE1:6-10\%P.L & 2,47 & 0,02 & 0,79 & 2,52 & 0,02 & 0,98 \\
\hline
\end{tabular}

Os blocos feitos com o pó de resíduo orgânico apresentaram valores de massa específica semelhante aos blocos de referência para cada um dos traços estudados, exceto para o traço 1:15. Tal comportamento era esperado pelos resultados obtidos nos ensaios dos corpos de prova. Por consequência, a dosagem do resíduo causou um adequado empacotamento entre as partículas do pó e do cimento.

As dosagens pertencentes ao traço 1:6 apresentaram os maiores valores médios de massa específica e, as dosagens do traço 1:15, com menor consumo de cimento, obtiveram os menores valores médios para essa propriedade.

\subsubsection{Blocos com adição da fibra de sisal}

Na Tabela 6.4 encontram-se os resultados das massas específicas dos blocos com adição do sisal e do bloco de referência.

Tabela 6.4 - Massa específica dos blocos com adição da fibra de sisal (Fonte: autor)

\begin{tabular}{|c|c|c|c|c|c|c|}
\hline \multirow{2}{*}{$\begin{array}{l}\text { Tipo de } \\
\text { Bloco }\end{array}$} & \multicolumn{3}{|c|}{$\begin{array}{c}\text { Massa específica seca ao } \\
\operatorname{ar}\left(\mathrm{g} / \mathrm{cm}^{3}\right) \\
\end{array}$} & \multicolumn{3}{|c|}{$\begin{array}{c}\text { Massa específica saturada } \\
\left(\mathrm{g} / \mathrm{cm}^{3}\right)\end{array}$} \\
\hline & Média & $S_{d}$ & C.V $(\%)$ & Média & $S_{d}$ & C.V $(\%)$ \\
\hline BE1:10-Ref & 2,41 & 0,02 & 0,83 & 2,48 & 0,02 & 0,81 \\
\hline BE1:10-F1 & 2,21 & 0,04 & 1,70 & 2,35 & 0,03 & 1,49 \\
\hline BE1:10-F2 & 2,27 & 0,02 & 1,08 & 2,39 & 0,01 & 0,46 \\
\hline
\end{tabular}

Os valores de massa específica seca ao ar e saturada foram menores para os blocos reforçados com fibras que para os blocos sem fibras. Segundo Silva (2010) e Savastano Jr, Warden e Coutts (2003), compósitos com adição do sisal apresentam menor densidade e maior absorção devido à natureza porosa das fibras criando ao nível da microestrutura uma maior rede capilar e maior número de vazios no concreto. Além disso, as fibras atuam como agentes incorporadores de ar quando são introduzidas na mistura. 
O bloco com fibra que teve a matriz modificada pelo cimento Portland CP III e adição de sílica ativa (BE1:10-F2) apresentou maior valor médio de massa específica com relação ao bloco reforçado com cimento Portland ARI (BE1:10-F1). Isso é dado pela reação pozolânica que diminui a quantidade de $\mathrm{CH}$, produto frágil e solúvel, e favorece a formação de uma quantidade adicional de C-S-H melhorando a interface pasta/agregado. Além do efeito químico de reação pozolânica, as partículas extremamente finas da sílica atuam fisicamente aumentando a densidade da matriz e a zona de transição. $\mathrm{O}$ resultado foi um concreto mais denso e com menor quantidade de vazios.

\subsubsection{Absorção de água}

\subsubsection{Blocos produzidos com os pós residuais}

A realização do ensaio para o cálculo da absorção de água dos blocos foi a partir da determinação da massa saturada e a massa seca em estufa. A Tabela 6.5 apresenta a absorção para cada série de blocos com adição dos pós residuais.

Tabela 6.5 - Absorção de água dos blocos produzidos com os pós residuais (Fonte: autor)

\begin{tabular}{lccc}
\hline \multirow{2}{*}{ Tipo de Bloco } & \multicolumn{3}{c}{ Absorção de água (\%) } \\
\cline { 2 - 4 } & Média & $\mathbf{S}_{\mathbf{d}}$ & $\mathbf{C . V}(\boldsymbol{\%})$ \\
\hline BE1:15-Ref & 6,24 & 0,28 & 4,49 \\
BE1:15-5\%P.L & 6,46 & 0,18 & 2,79 \\
BE1:10-Ref & 5,78 & 0,20 & 3,46 \\
BE1:10-5\%P.L & 5,02 & 0,21 & 4,18 \\
BE1:6-Ref & 4,58 & 0,21 & 4,59 \\
BE1:6-10\%P.L & 4,32 & 0,16 & 3,70 \\
\hline
\end{tabular}

A NBR 6136: 2014 estabelece que a absorção de água, para blocos estruturais de concreto, deve ser menor ou igual a $10 \%$. Todos os blocos apresentaram valores inferiores ao limite da norma, cumprindo com o requisito estabelecido. Com relação ao tipo de traço, houve influência significativa da classe de resistência sobre a absorção de água. Nesse caso, os menores valores médios de absorção foram obtidos para as unidades do traço 1:6 (maior consumo de cimento) e os maiores valores médios para as unidades do traço 1:15 (menor consumo de cimento).

A absorção dos blocos com pó de resíduo orgânico foi menor com relação aos blocos de referência para os traços 1:10 e 1:6 devido a um concreto com menos porosidade. Já para o traço 1:15, produto do menor desempenho do pó como fíler para preencher os espaços vazios 
na pasta de cimento, a absorção de água do blocos BE1:15-5\%P.L foi maior com relação ao bloco BE1:15-Ref.

\subsubsection{Blocos com adição da fibra de sisal}

Os resultados da propriedade de absorção de água encontram-se na Tabela 6.6.

Tabela 6.6 - Absorção de água dos blocos com adição da fibra de sisal (Fonte: autor)

\begin{tabular}{lccc}
\hline \multirow{2}{*}{$\begin{array}{c}\text { Tipo de } \\
\text { Bloco }\end{array}$} & \multicolumn{3}{c}{ Absorção de água (\%) } \\
\cline { 2 - 4 } & Média & $\mathbf{S}_{\mathbf{d}}$ & C.V $(\boldsymbol{\%})$ \\
\hline BE1:10-Ref & 5,78 & 0,20 & 3,46 \\
BE1:10-F1 & 8,03 & 0,17 & 2,12 \\
BE1:10-F2 & 7,57 & 0,15 & 1,96 \\
\hline
\end{tabular}

Os blocos com adição de fibra apresentaram maior absorção quando comparados ao bloco de referência. Segundo Li e Ye (2000), a fibra tem uma região central vazia, o lúmen, que dá acesso à penetração da água, o que acarreta elevada absorção. No entanto, todas as unidades com adição do sisal cumpriram com os requisitos da NBR 6136: 2014, com relação à absorção máxima de água. O bloco BE1:10-F2 apresentou menor absorção que o bloco BE1:10-F1 devido a uma melhoria da zona de interface e refinamento da estrutura de poros pela reação pozolânica.

\subsubsection{Teor de umidade}

A NBR 6136: 2014 expressa que o máximo valor de umidade que pode apresentar os blocos é de $40 \%$ com variação da umidade relativa anual entre $50 \%$ e $75 \%$. Esse é o caso do Laboratório de Estruturas localizado em São Carlos no estado de São Paulo. Portanto, os blocos cumprem amplamente com as exigências da norma como mostra a Tabela 6.7.

Tabela 6.7 - Teor de umidade dos blocos (Fonte: autor)

\begin{tabular}{lccc}
\hline \multirow{2}{*}{ Tipo de Bloco } & \multicolumn{3}{c}{ Teor de umidade $(\%)$} \\
\cline { 2 - 4 } & Média & $\mathbf{S}_{\mathbf{d}}$ & $\mathbf{C . V}(\boldsymbol{\%})$ \\
\hline BE1:15-Ref & 36,56 & 3,00 & 8,20 \\
BE1:15-5\%P.L & 33,37 & 2,52 & 7,56 \\
BE1:10-Ref & 38,79 & 3,74 & 9,63 \\
BE1:10-5\%P.L & 32,35 & 2,23 & 6,89 \\
BE1:10-F1 & 24,79 & 1,39 & 5,61 \\
BE1:10-F2 & 28,94 & 2,35 & 8,11 \\
BE1:6-Ref & 34,39 & 2,48 & 7,21 \\
BE1:6-10\%P.L & 29,28 & 2,48 & 8,48 \\
\hline
\end{tabular}




\subsection{Resistência à compressão dos blocos e meio-blocos}

A mesma análise estatística, feita para a resistência à compressão dos corpos de prova com pó de pedra e pó de resíduo orgânico, foi realizada para os blocos e meio-blocos. Como foi mencionado no item 5.4.1.3, o valor médio da resistência à compressão das unidades obtido por meio de um número limitado de observações no laboratório não oferece a informação precisa dos parâmetros estatísticos da população, como média, desvio padrão e coeficiente de variação. Entretanto, por meio da reamostragem do Bootstrap pode ser conhecido o intervalo de confiança em cada série de blocos e meio-blocos que apresenta 95\% de probabilidade de conter os verdadeiros valores estatísticos populacionais. Para complementar o estudo estatístico é realizada também as análises da diferença entre duas médias.

\subsubsection{Blocos produzidos com os pós residuais}

A Tabela 6.8 mostra os intervalos de confiança da média, desvio padrão e coeficiente de variação da resistência à compressão, assim como a resistência característica da população dos blocos com os pós residuais para uma confiabilidade de 95\%. Esses resultados foram calculados em função da área bruta das unidades.

Tabela 6.8 - Resistência à compressão média e característica dos blocos com os pós residuais (Fonte: autor)

\begin{tabular}{|c|c|c|c|c|c|c|c|c|}
\hline \multirow{3}{*}{ Tipo de Bloco } & \multicolumn{8}{|c|}{ Resistência à compressão (MPa) } \\
\hline & \multicolumn{2}{|c|}{ Média (fbm) } & \multicolumn{2}{|c|}{ Sd } & \multicolumn{2}{|c|}{$\mathrm{CV}(\%)$} & \multicolumn{2}{|c|}{ Caract. (fbk) } \\
\hline & Inferior & Superior & Inferio & Superior & Inferio & Superior & Inferior & Superior \\
\hline BE1:15-Ref & 6,26 & 6,96 & 0,37 & 0,74 & 5,91 & 10,63 & 5,19 & 5,79 \\
\hline BE1:15-5\%P.L & 5,30 & 6,23 & 0,43 & 0,94 & 8,11 & 15,09 & 3,95 & 4,87 \\
\hline BE1:10-Ref & 10,77 & 12,31 & 1,06 & 1,90 & 9,84 & 15,43 & 8,04 & 10,18 \\
\hline BE1:10-5\%P.L & 11,09 & 12,86 & 0,95 & 1,20 & 8,57 & 9,33 & 8,23 & 10,86 \\
\hline BE1:6-Ref & 14,35 & 15,29 & 0,67 & 1,13 & 4,67 & 7,39 & 12,67 & 13,85 \\
\hline BE1:6-10\%P.L & 14,75 & 15,95 & 0,71 & 1,66 & 4,81 & 10,41 & 12,90 & 14,01 \\
\hline
\end{tabular}

Analisando-se os resultados de resistência à compressão média, os valores do intervalo das unidades com 5\% de pó de resíduo para o traço 1:15 (BE1:15-\%\%P.L) foram menores com relação aos valores do intervalo do bloco de referência (BE1:15-Ref). Tal comportamento era esperado pelos resultados obtidos nos ensaios dos corpos de prova. Possivelmente, o maior conteúdo de agregados para esse traço provocou maior área superficial de agregados e o pó residual não conseguiu o correto empacotamento na mistura. 
Por outro lado, esses blocos alcançaram resistência característica que pode variar de 3,95 a 4,87 MPa. A pesar de o limite inferior ser menor que $4 \mathrm{MPa}$, a diferença é mínima e podem ser enquadrados na classe de blocos estruturais de $4 \mathrm{MPa}$.

Com relação aos traços 1:10 e 1:6, nota-se que as unidades com 5\% e 10\% de pó de resíduo orgânico, respectivamente, apresentaram os intervalos de resistência média à compressão superiores aos blocos de referência. Uma maior densidade, menor índice de vazios e absorção na mistura implica um concreto mais resistente. Com relação à resistência característica, os intervalos de confiança de todos os blocos apresentaram os valores pretendidos para esses traços, que são 8 e $12 \mathrm{MPa}$, respectivamente.

Na Figura 6.1 é mostrado o diagrama de caixa dos valores médios da resistência de cada um dos blocos para os diferentes traços para uma melhor compreensão dos resultados.

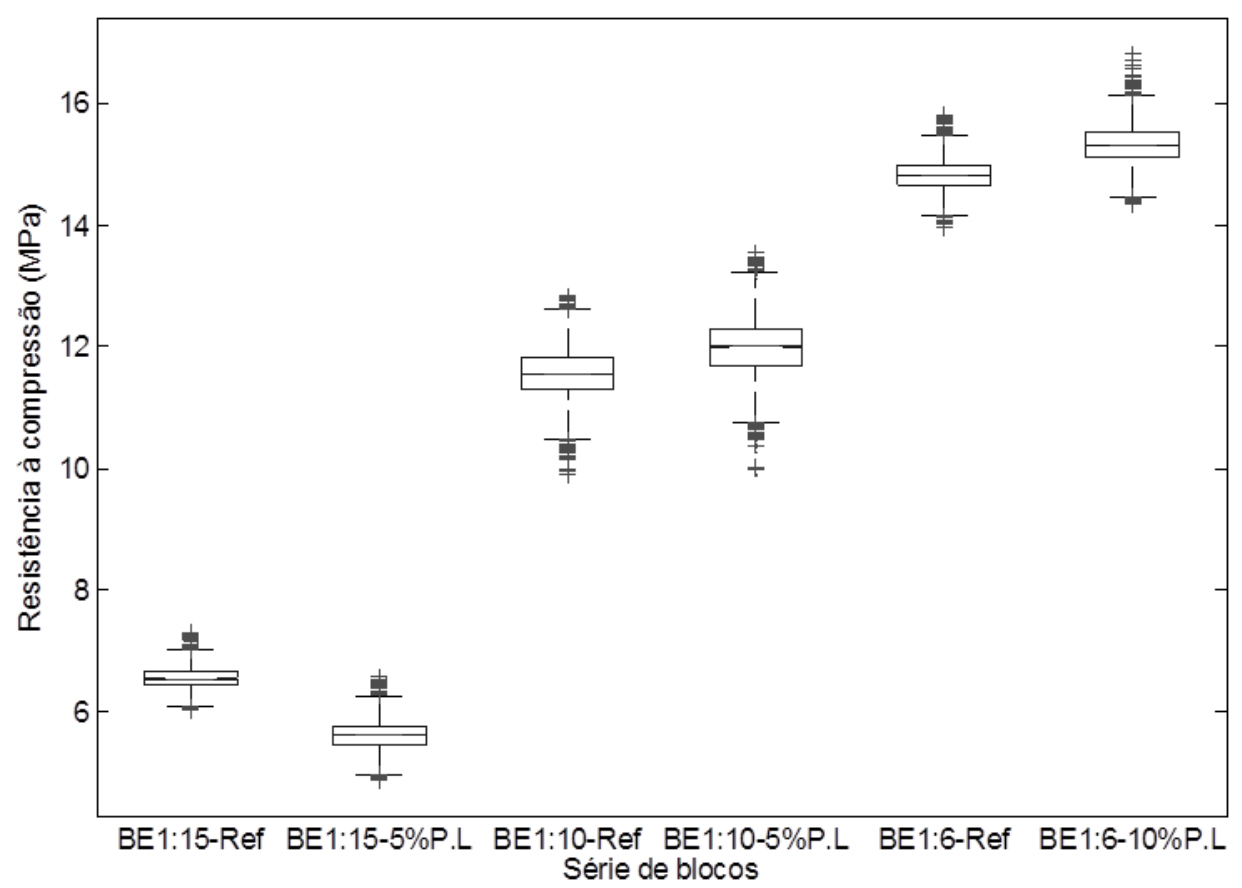

Figura 6.1 - Diagrama de caixa para os dados da resistência à compressão dos blocos com os pós residuais (Fonte: autor)

Fazendo-se uma comparação entre os três traços estudados, pode-se observar que a medida que aumentou o consumo de cimento houve um aumento da resistência dos blocos. As misturas com pó de resíduo orgânico substituindo o cimento apresentaram um ligeiro aumento da resistência média á compressão com relação aos blocos de referência exceto para o traço 1:15. Todos os blocos são classificados como blocos estruturais.

As séries BE1:10-Ref e BE1:10-5\%P.L apresentaram maior altura das caixas, portanto, seus valores foram mais dispersos e menos homogêneos com relação ao resto dos 
blocos. É por isso que os valores dos intervalos de confiança do desvio padrão para esses blocos foram maiores com relação ao resto das unidades.

A Tabela 6.9 mostra a probabilidade de aceitação das hipóteses nulas da resistência média à compressão de duas populações para cada série de blocos.

Tabela 6.9 - Probabilidade de que as hipóteses nulas sejam aceitas para os blocos com os pós residuais (Fonte: autor)

\begin{tabular}{|c|c|c|c|c|c|c|}
\hline \multirow{2}{*}{ Traço 1:15 } & \multicolumn{3}{|c|}{ BE1:15-Ref } & \multicolumn{3}{|c|}{ BE1:15-5\%P.L } \\
\hline & $\mathbf{H}_{01}$ & $\mathbf{H}_{02}$ & $\mathbf{H}_{\mathbf{0 3}}$ & $\mathrm{H}_{01}$ & $\mathrm{H}_{02}$ & $\mathbf{H}_{03}$ \\
\hline$\overline{\mathrm{BE} 1: 1}$ & 0 & 100 & 0 & 0 & 21,37 & 78,63 \\
\hline BE1: & 78,63 & 21,37 & 0 & 0 & 100 & 0 \\
\hline \multirow{2}{*}{ Traço 1:10 } & \multicolumn{3}{|c|}{ BE1:10-Ref } & \multicolumn{3}{|c|}{ BE1:10-5\%P.L } \\
\hline & $\mathbf{H}_{01}$ & $\mathbf{H}_{02}$ & $\mathbf{H}_{03}$ & $\mathrm{H}_{01}$ & $\mathbf{H}_{02}$ & $\mathbf{H}_{03}$ \\
\hline$\overline{\mathrm{BE} 1: 1 \mathrm{C}}$ & 0 & 100 & 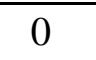 & 10,55 & 87,99 & 1,46 \\
\hline $\mathrm{BE} 1: 1 \mathrm{C}$ & 1,46 & 87,99 & 10 , & 0 & 100 & 0 \\
\hline \multirow{2}{*}{ Traço 1:6 } & \multicolumn{3}{|c|}{ BE1:6-Ref } & \multicolumn{3}{|c|}{ BE1:6-10\% P.L } \\
\hline & $\mathbf{H}_{01}$ & $\mathrm{H}_{02}$ & $\mathbf{H}_{03}$ & $\mathrm{H}_{01}$ & $\mathbf{H}_{02}$ & $\mathbf{H}_{03}$ \\
\hline BE1:6-Ref & 0 & 100 & 0 & 23,08 & 76,24 & 0,68 \\
\hline BE1:6-10\%P.L & 0,68 & 76,24 & 23,08 & 0 & 100 & 0 \\
\hline
\end{tabular}

Pode-se confirmar estatisticamente que, para o traço $1: 15$ existe $78,63 \%$ de probabilidade que a resistência média do bloco com 5\% de pó orgânico seja inferior ao bloco de referência e $21,37 \%$ que sejam iguais. Já para o traço 1:10, as unidades com adição do resíduo apresentaram $87,99 \%$ de probabilidade que a resistência seja igual ao bloco controle e $10,55 \%$ que seja superior. Com relação ao traço de maior consumo de cimento (1:6), o bloco com $10 \%$ de resíduo teve $23,08 \%$ de probabilidade de apresentar maior resistência comparada ao concreto de referência e $76,24 \%$ de serem iguais. Dessa forma, pode-se dizer que, para uma confiabilidade de 95\%, o pó residual orgânico substituindo parte do cimento na mistura causou um correto desempenho mecânico nos blocos de concreto para os traços médio e rico. Apesar de não apresentar propriedades aglomerantes, o resíduo atua como fíler capaz de preencher os vazios do material e refinar os poros da pasta de cimento.

\subsubsection{Meio-blocos produzidos com os pós residuais}

A Tabela 6.10 mostra os intervalos de confiança da média, desvio padrão e coeficiente de variação da resistência à compressão, assim como a resistência característica da população dos meio-blocos com os pós residuais para uma confiabilidade de 95\%. Esses resultados foram calculados em função da área bruta das unidades. 
Tabela 6.10 - Resistência à compressão média e característica dos meio-blocos com os pós residuais (Fonte: autor)

\begin{tabular}{|c|c|c|c|c|c|c|c|c|}
\hline \multirow{3}{*}{$\begin{array}{l}\text { Tipo de Meio- } \\
\text { Blocos }\end{array}$} & \multicolumn{8}{|c|}{ Resistência à compressão (MPa) } \\
\hline & \multicolumn{2}{|c|}{ Média (fbm) } & \multicolumn{2}{|c|}{ Sd } & \multicolumn{2}{|c|}{$\mathrm{CV}(\%)$} & \multicolumn{2}{|c|}{ Caract. (fbk) } \\
\hline & Inferior & Superior & Inferior & Superior & Inferior & Superior & Inferior & Superior \\
\hline$\overline{\text { BE1:15-Ref }}$ & 6,20 & 6,66 & 0,24 & 0,56 & 3,87 & 8,41 & 5,48 & 5,89 \\
\hline BE1:15-5\%P.L & 5,71 & 6,39 & 0,34 & 0,82 & 5,95 & 12,83 & 4,67 & 5,23 \\
\hline BE1:10-Ref & 9,54 & 10,62 & 0,75 & 1,33 & 7,86 & 12,52 & 7,66 & 9,14 \\
\hline BE1:10-5\%P.L & 9,97 & 11,22 & 0,88 & 1,58 & 8,83 & 14,08 & 7,62 & 9,50 \\
\hline BE1:6-Ref & 12,92 & 13,64 & 0,51 & 0,86 & 3,95 & 6,30 & 11,82 & 12,53 \\
\hline BE1:6-10\%P.L & 13,41 & 14,37 & 0,55 & 1,29 & 4,10 & 8,98 & 11,77 & 12,78 \\
\hline
\end{tabular}

Os meio-blocos apresentaram o mesmo comportamento mecânico dos blocos inteiros. Nota-se que os meio-blocos correspondentes aos traços 1:10 e 1:6 tiveram melhor desempenho aqueles com adição do pó residual orgânico. Já para o traço com menor consumo de cimento, os meio-blocos de referência alcançaram maior resistência.

A Figura 6.2 mostra o diagrama de caixa dos valores médios da resistência de cada um dos meio-blocos para os diferentes traços.

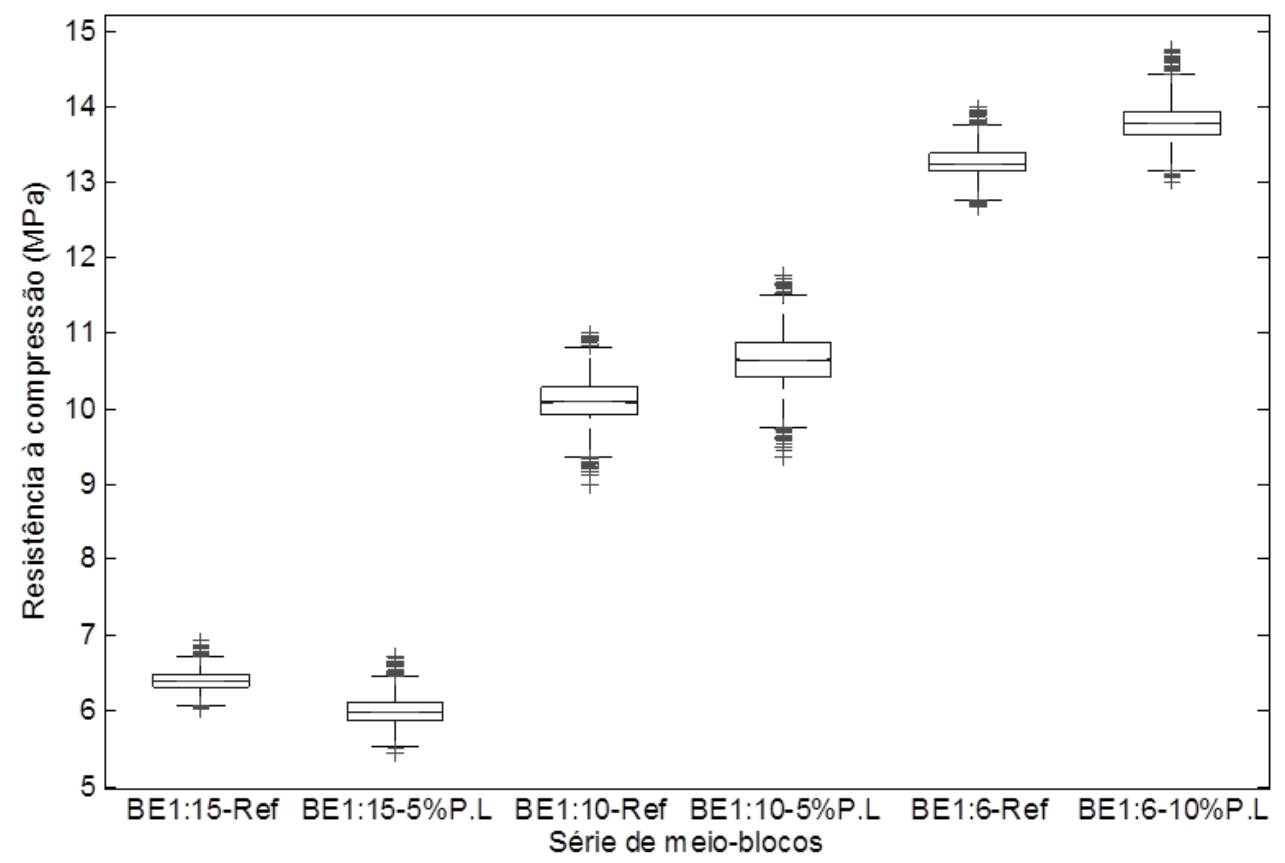

Figura 6.2 - Diagrama de caixa para os dados da resistência à compressão dos meio-blocos com os pós residuais (Fonte: autor)

Por meio do diagrama pode-se comprovar de forma visual o comportamento mecânico dos meio-blocos corroborando a análise anterior.

A Tabela 6.11 mostra a probabilidade de aceitação das hipóteses nulas da resistência média à compressão de duas populações para cada série de blocos. 
Tabela 6.11 - Probabilidade de que as hipóteses nulas sejam aceitas para os meio-blocos com os pós residuais (Fonte: autor)

\begin{tabular}{|c|c|c|c|c|c|c|}
\hline \multirow{2}{*}{ Traço 1:15 } & \multicolumn{3}{|c|}{ BE1:15-Ref } & \multicolumn{3}{|c|}{ BE1:15-5\%P.L } \\
\hline & $\mathbf{H}_{01}$ & $\mathbf{H}_{02}$ & $\mathbf{H}_{03}$ & $\mathbf{H}_{01}$ & $\mathbf{H}_{02}$ & $\mathbf{H}_{03}$ \\
\hline$\overline{\mathrm{BE} 1: 15-\mathrm{Ref}}$ & 0 & 100 & 0 & 0,06 & 45,06 & 54,88 \\
\hline BE1:15-5\%P.L & 54,88 & 45,06 & 0,06 & 0 & 100 & 0 \\
\hline \multirow{2}{*}{ Traço 1:10 } & \multicolumn{3}{|c|}{ BE1:10-Ref } & \multicolumn{3}{|c|}{ BE1:10-5\%P.L } \\
\hline & $\mathbf{H}_{01}$ & $\mathrm{H}_{02}$ & $\mathbf{H}_{03}$ & $\mathrm{H}_{01}$ & $\mathbf{H}_{02}$ & $\mathbf{H}_{03}$ \\
\hline BE1:10-Ref & 0 & 100 & 0 & 34,12 & 65,66 & 0,22 \\
\hline BE1:10-5\%P.L & 0,22 & 65,66 & 34,12 & 0 & 100 & 0 \\
\hline \multirow{2}{*}{ Traço 1:6 } & \multicolumn{3}{|c|}{ BE1:6-Ref } & \multicolumn{3}{|c|}{ BE1:6-10\%P.L } \\
\hline & $\mathbf{H}_{01}$ & $\mathbf{H}_{02}$ & $\mathbf{H}_{03}$ & $\mathbf{H}_{01}$ & $\mathbf{H}_{02}$ & $\mathbf{H}_{03}$ \\
\hline$\overline{B E 1: 6-R e f}$ & 0 & 100 & 0 & 51,54 & 48,04 & 0,42 \\
\hline BE1:6-10\%P.L & 0,42 & 48,04 & 51,54 & 0 & 100 & 0 \\
\hline
\end{tabular}

Analisando a Tabela 6.11, pode-se confirmar estatisticamente que, para o traço 1:15, existe $54,88 \%$ de probabilidade que a resistência média do meio-bloco com $5 \%$ de pó de resíduo orgânico seja inferior ao bloco de referência e 45,06\% que sejam iguais. Comparando os blocos e os meio-blocos para esse traço, os meio-blocos com o resíduo apresentaram maior porcentagem de valores iguais aos exemplares de referência, por conseguinte, o pó de resíduo orgânico teve melhor desempenho nos meio-blocos que nos blocos. Já para o traço 1:10, os meio-blocos com adição do resíduo apresentaram 65,66\% de probabilidade que a resistência seja igual ao bloco controle e $34,12 \%$ que seja superior. Com relação ao traço de maior consumo de cimento (1:6), o bloco com $10 \%$ de resíduo teve $51,54 \%$ de probabilidade de apresentar maior resistência comparada à unidade de referência e 48,04\% de serem iguais.

\subsubsection{Blocos com adição de fibra de sisal}

A Tabela 6.12 mostra os intervalos de confiança da média, desvio padrão e coeficiente de variação da resistência à compressão, assim como a resistência característica da população dos blocos com adição de fibra de sisal para uma confiabilidade de 95\%. Esses resultados foram calculados em função da área bruta das unidades. 
Tabela 6.12 - Resistência à compressão média e característica dos blocos com adição da fibra de sisal (Fonte: autor)

\begin{tabular}{|c|c|c|c|c|c|c|c|c|}
\hline \multirow{3}{*}{ Tipo de Bloco } & \multicolumn{8}{|c|}{ Resistência à compressão (MPa) } \\
\hline & \multicolumn{2}{|c|}{ Média (fbm) } & \multicolumn{2}{|c|}{$\mathrm{Sd}$} & \multicolumn{2}{|c|}{$\mathrm{CV}(\%)$} & \multicolumn{2}{|c|}{ Caract. (fbk) } \\
\hline & Inferiol & Superior & Inferio & Superior & Inferio & Superior & Inferio & Superior \\
\hline BE1:10-Ref & 10,77 & 12,31 & 1,06 & 1,90 & 9,84 & 15,43 & 8,18 & 10,18 \\
\hline BE1:10-F1 & 7,72 & 8,49 & 0,55 & 0,94 & 7,12 & 11,07 & 6,43 & 7,40 \\
\hline BE1:10-F2 & 8,92 & 9,73 & 0,56 & 1,07 & 6,28 & 11,00 & 8,03 & 8,71 \\
\hline
\end{tabular}

Os blocos com fibras apresentaram diminuição da resistência à compressão em relação aos blocos de referência. As fibras, além de diminuir a densidade, de provocar maior absorção e de aumentar o número de vazios no concreto; também permite a formação de mais uma zona de interface entre as fibras e a pasta de cimento, além da interface agregado/pasta. Dessa forma, existe no concreto reforçado maior número de regiões porosas, frágeis e microfissuradas com relação ao concreto sem fibras, provocando pior desempenho do material.

Com relação às unidades com sisal, o intervalo de confiança da resistência média à compressão do bloco BE1:10-F2 foi superior ao bloco BE1:10-F1. Esse comportamento era previsto pelos resultados de massa específica e absorção de água obtidos para essas unidades. À vista disso, fica comprovado que a reação pozolânica ocorrida na matriz modificada pela adição de sílica ativa (BE1:10-F2) melhorou a zona de interface entre a matriz e a fibra, refinou os poros e aumentou a resistência do concreto com relação ao bloco reforçado com o cimento Portland ARI (BE1:10-F1).

Segundo os intervalos de resistência característica, as unidades sem adição de fibras e as unidades com fibras que tiveram a matriz modificada podem ser enquadradas na classe de blocos estruturais de $8 \mathrm{MPa}$; já as unidades reforçadas usando o cimento Portland ARI podem ser enquadradas na classe de blocos estruturais de $6 \mathrm{MPa}$.

Comparando de forma prática os resultados dos três grupos de bloco, é mostrado na Figura 6.3 o diagrama de caixa dos valores médios da resistência à compressão. 


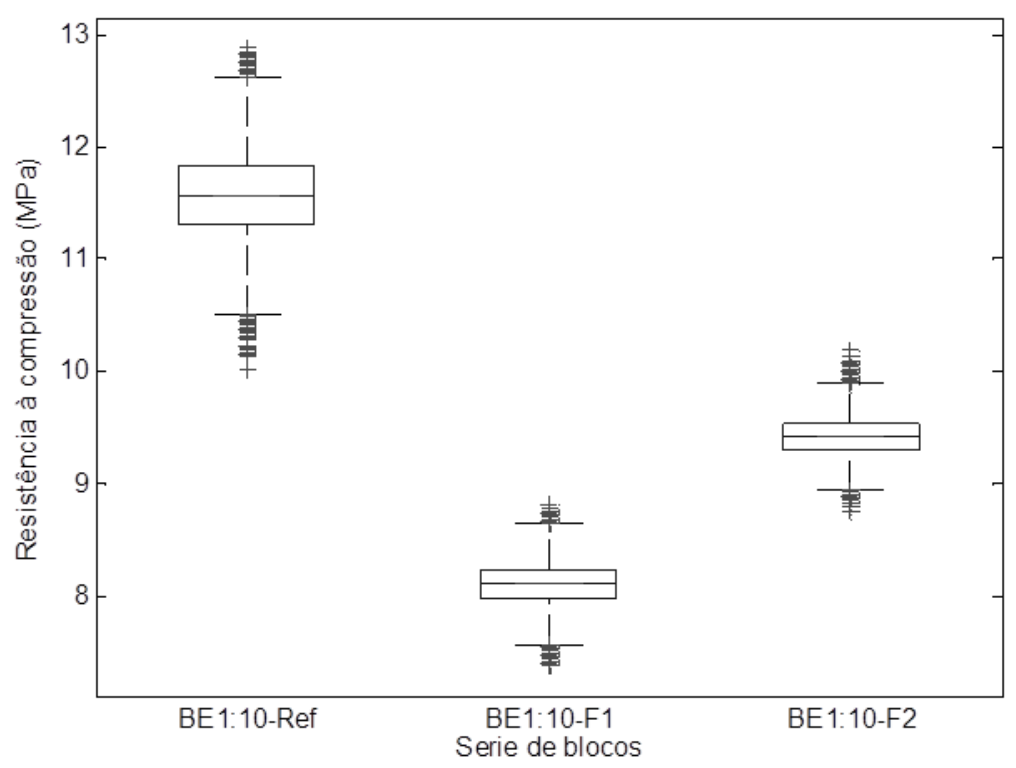

Figura 6.3 - Diagrama de caixa para os dados da resistência à compressão dos blocos com fibra de sisal (Fonte: autor)

De forma geral, os dados dos três grupos apresentaram uma distribuição simétrica e o bloco BE1:10 Ref teve valores mais dispersos com relação aos blocos reforçados com fibras devido a caixa apresentar uma maior altura.

A Tabela 6.13 mostra a probabilidade de aceitação das três hipóteses nulas da resistência à compressão sempre entre duas populações, uma localizada nas filas e a outra nas colunas.

Tabela 6.13 - Probabilidade de que as hipóteses nulas sejam aceitas para os blocos com fibra de sisal (Fonte: autor)

\begin{tabular}{|c|c|c|c|c|c|c|c|c|c|}
\hline \multirow{2}{*}{$\begin{array}{l}\text { Tipo de } \\
\text { Blocos } \\
\end{array}$} & \multicolumn{3}{|c|}{ BE1:10-Ref } & \multicolumn{3}{|c|}{ BE1:10-F1 } & \multicolumn{3}{|c|}{ BE1:10-F2 } \\
\hline & $\mathbf{H}_{01}$ & $\mathbf{H}_{02}$ & $\mathbf{H}_{03}$ & $\mathbf{H}_{01}$ & $\mathbf{H}_{02}$ & $\mathbf{H}_{03}$ & $\mathbf{H}_{01}$ & $\mathrm{H}_{02}$ & $\mathrm{H}_{03}$ \\
\hline BE1:10-Ref & 0 & 100 & 0 & 0 & 0 & 100 & 0 & 0 & 100 \\
\hline BE1:10-F1 & 100 & 0 & 0 & 0 & 100 & 0 & 100 & 0 & 0 \\
\hline BE1:10-F2 & 100 & 0 & 0 & 0 & 0 & 100 & 0 & 100 & 0 \\
\hline
\end{tabular}

O bloco BE1:10- Ref teve 100\% de probabilidade de a resistência à compressão ser estatisticamente maior com relação às unidades reforçadas com o sisal. Isso pode ser comprovado comparando-se os valores correspondentes à primeira fila (BE1:10-Ref) com a segunda coluna (BE1:10-F1) e a terceira coluna (BE1:10-F2) da hipótese nula $\mathrm{H}_{03}$. Já o bloco BE1:10-F2 (fila 3) quando comparado com o bloco BE1:10-F1 (coluna 2) apresentou 100\% de probabilidade de a hipótese nula $\mathrm{H}_{03}\left(\mathrm{u}_{1}>\mathrm{u}_{2}\right)$ ser aceita. Desse modo, para um nível de significância de 5\%, fica demostrado estaticamente que o bloco com a matriz modificada (BE1:10-F2) teve melhor desempenho mecânico que o bloco com o cimento de alto teor de clínquer (BE1:10-F1). 


\subsubsection{Meio-blocos com adição de fibra de sisal}

A Tabela 6.14 mostra os intervalos de confiança da média, desvio padrão e coeficiente de variação da resistência à compressão, assim como a resistência característica da população dos meio-blocos com adição do sisal para uma confiabilidade de 95\%. Esses resultados foram calculados em função da área bruta das unidades.

Tabela 6.14 - Resistência à compressão média e característica dos meio-blocos com adição de fibra de sisal (Fonte: autor)

\begin{tabular}{|c|c|c|c|c|c|c|c|c|}
\hline \multirow{3}{*}{$\begin{array}{c}\text { Tipo de Meio- } \\
\text { Bloco }\end{array}$} & \multicolumn{8}{|c|}{ Resistência à compressão (MPa) } \\
\hline & \multicolumn{2}{|c|}{ Média (fbm) } & \multicolumn{2}{|c|}{$\mathrm{Sd}$} & \multicolumn{2}{|c|}{$\mathrm{CV}(\%)$} & \multicolumn{2}{|c|}{ Caract. (fbk) } \\
\hline & Inferior & Superior & Inferior & Superior & Inferior & Superior & Inferior & Superior \\
\hline BEl:10-Ref & 9,54 & 10,62 & 0,75 & 1,33 & 7,86 & 12,52 & 7,66 & 9,14 \\
\hline BEl:10-F1 & 7,64 & 8,20 & 0,40 & 0,69 & 5,24 & 8,41 & 6,69 & 7,40 \\
\hline BE1:10-F2 & 8,64 & 9,14 & 0,35 & 0,62 & 4,05 & 6,78 & 7,86 & 8,36 \\
\hline
\end{tabular}

Os meio-blocos apresentaram o mesmo comportamento mecânico dos blocos inteiros. Nota-se que como os meio-blocos reforçados com a fibra tiveram menor desempenho com relação aos meio-blocos de referência, e as unidades BE1:10-F2 evidenciaram maior resistência à compressão comparadas com as unidades BE1:10-F1.

A Figura 6.4 mostra o diagrama de caixa dos valores médios da resistência de cada um dos meio-blocos com e sem adição de fibras. 


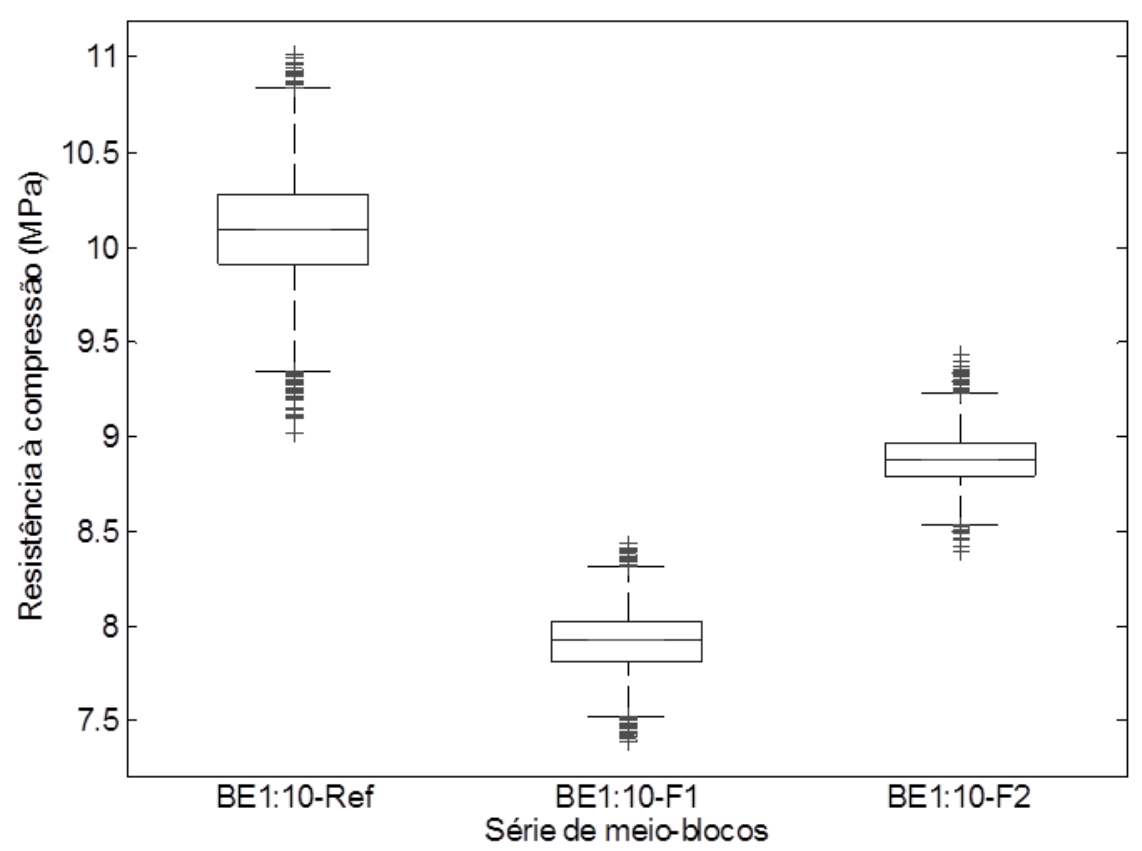

Figura 6.4 - Diagrama de caixa para os dados da resistência à compressão dos meio-blocos com fibra de sisal (Fonte: autor)

Por meio do diagrama pode-se comprovar de forma visual o comportamento mecânico dos meio-blocos corroborando a análise feita na Tabela 6.14 .

A Tabela 6.15 mostra a probabilidade de aceitação das hipóteses nulas da resistência média à compressão de duas populações para cada série de blocos.

Tabela 6.15 - Probabilidade de que as hipóteses nulas sejam aceitas para os meio-blocos com fibra de sisal (Fonte: autor)

\begin{tabular}{|c|c|c|c|c|c|c|c|c|c|}
\hline \multirow{2}{*}{$\begin{array}{c}\text { Tipo deMeio- } \\
\text { Blocos } \\
\end{array}$} & \multicolumn{3}{|c|}{ BE1:10-Ref } & \multicolumn{3}{|c|}{ BE1:10-F1 } & \multicolumn{3}{|c|}{ BE1:10-F2 } \\
\hline & $\mathrm{H}_{01}$ & $\mathbf{H}_{02}$ & $\mathbf{H}_{03}$ & $\mathrm{H}_{01}$ & $\mathrm{H}_{02}$ & $\mathbf{H}_{03}$ & $\mathrm{H}_{01}$ & $\mathbf{H}_{02}$ & $\mathbf{H}_{03}$ \\
\hline BE1:10-Ref & 0 & 100 & 0 & 0 & 0 & 100 & 0 & 1,08 & 98,92 \\
\hline BE1:10-F1 & 100 & 0 & 0 & 0 & 100 & 0 & 100 & 0 & 0 \\
\hline BE1:10-F2 & 98,92 & 1,08 & 0 & 0 & 0 & 100 & 0 & 100 & 0 \\
\hline
\end{tabular}

O meio-bloco BE1:10-Ref teve $100 \%$ e $98,92 \%$ de probabilidade de a hipótese nula $\mathrm{H}_{03}$ $\left(\mathrm{u}_{1}>\mathrm{u}_{2}\right)$ ser aceita com relação aos blocos BE1:10-F1 e BE1:10-F2, respectivamente. Portanto a resistência à compressão do bloco de referência é estatisticamente superior aos meio-blocos com adição do sisal. Com relação aos meio-blocos reforçados fica demostrado estaticamente que o meio-bloco com a matriz modificada (BE1:10-F2) teve melhor desempenho mecânico que o meio-bloco com o cimento Portland ARI (BE1:10-F1).

\subsection{Modos de ruptura dos blocos}

A Figura 6.5 apresenta a forma de ruptura dos blocos. 

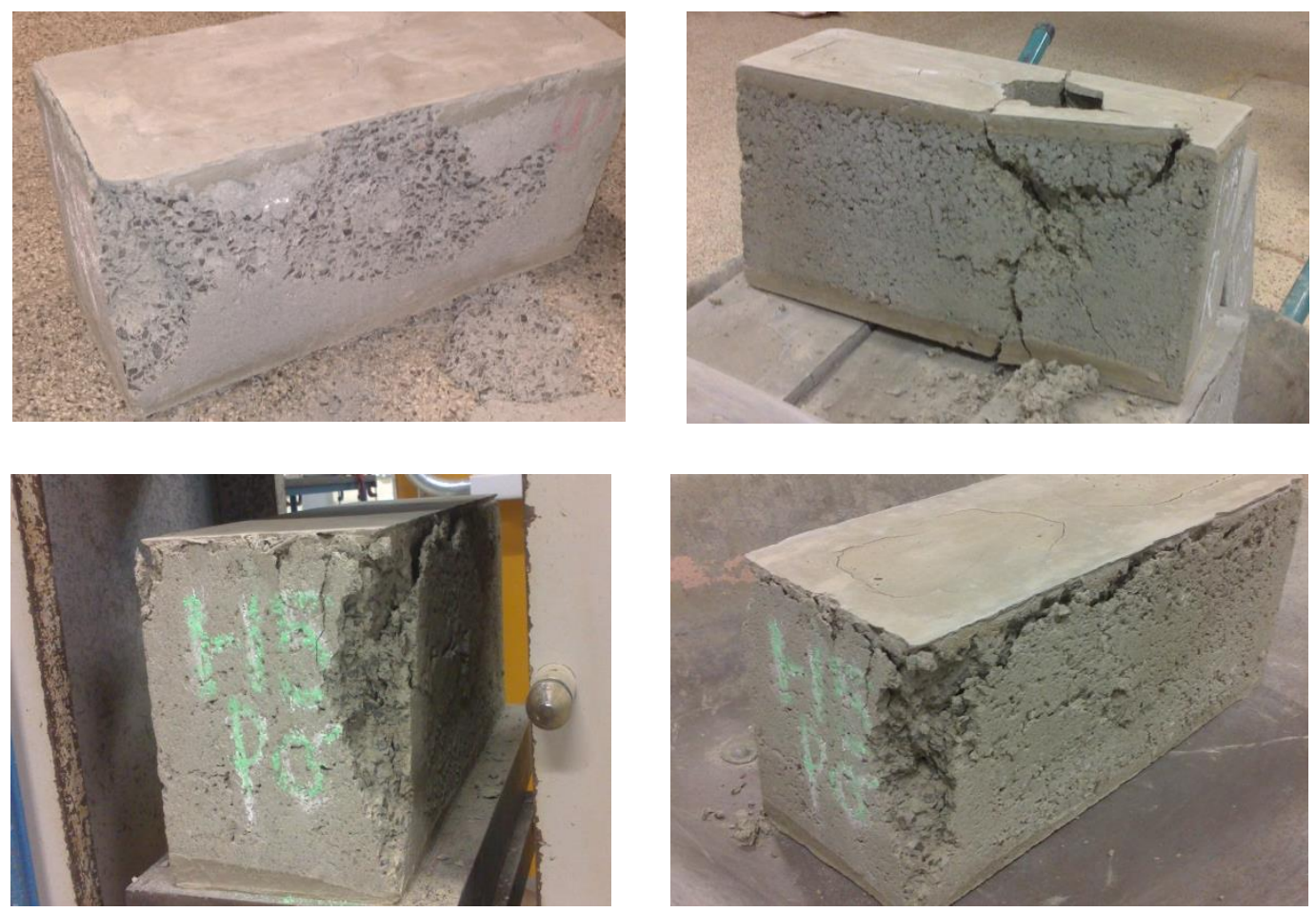

Figura 6.5 - Modo de ruptura dos blocos de concreto (Fonte: autor)

Segundo Mohamad, Lourenço e Roman (2007), o modo de ruptura dos blocos é dado pela restrição de deslocamento produzida pelo atrito entre a chapa e o bloco, ocasionando um estado de tensões multiaxiais. Isso leva a uma concentração de tensões fazendo com que a ruptura seja por esfacelamento das paredes do bloco. De forma geral, as unidades apresentaram rupturas em forma de cone, típica da compressão de um corpo de prova confinado nas extremidades com fissuras verticais nas paredes transversais.

Foi observado durante o ensaio de compressão que nas unidades pertencentes aos traços 1:15 e 1:10 ocorreu um rompimento com rápida propagação de fissuras. Já nos blocos mais resistentes correspondentes ao traço 1:6 ocorreu um colapso explosivo, como mostra a Figura 6.6. Entretanto, nas unidades com adição de fibra de sisal mostraram uma ruptura lenta, como se apresenta na Figura 6.7.

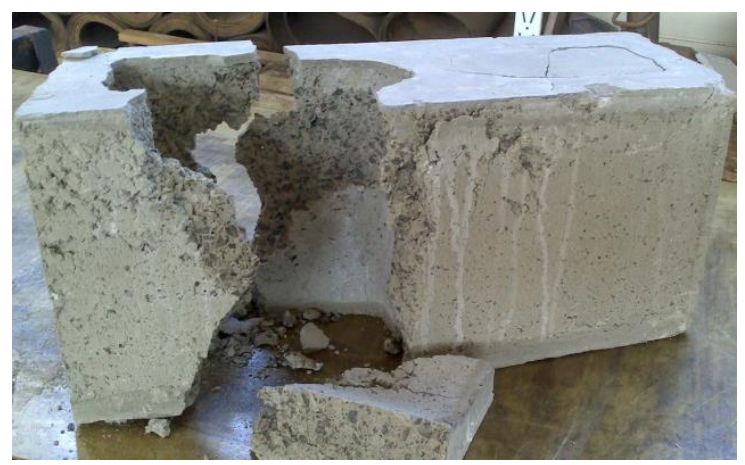

Figura 6.6 - Ruptura frágil dos blocos sem adição de fibra (Fonte: autor) 

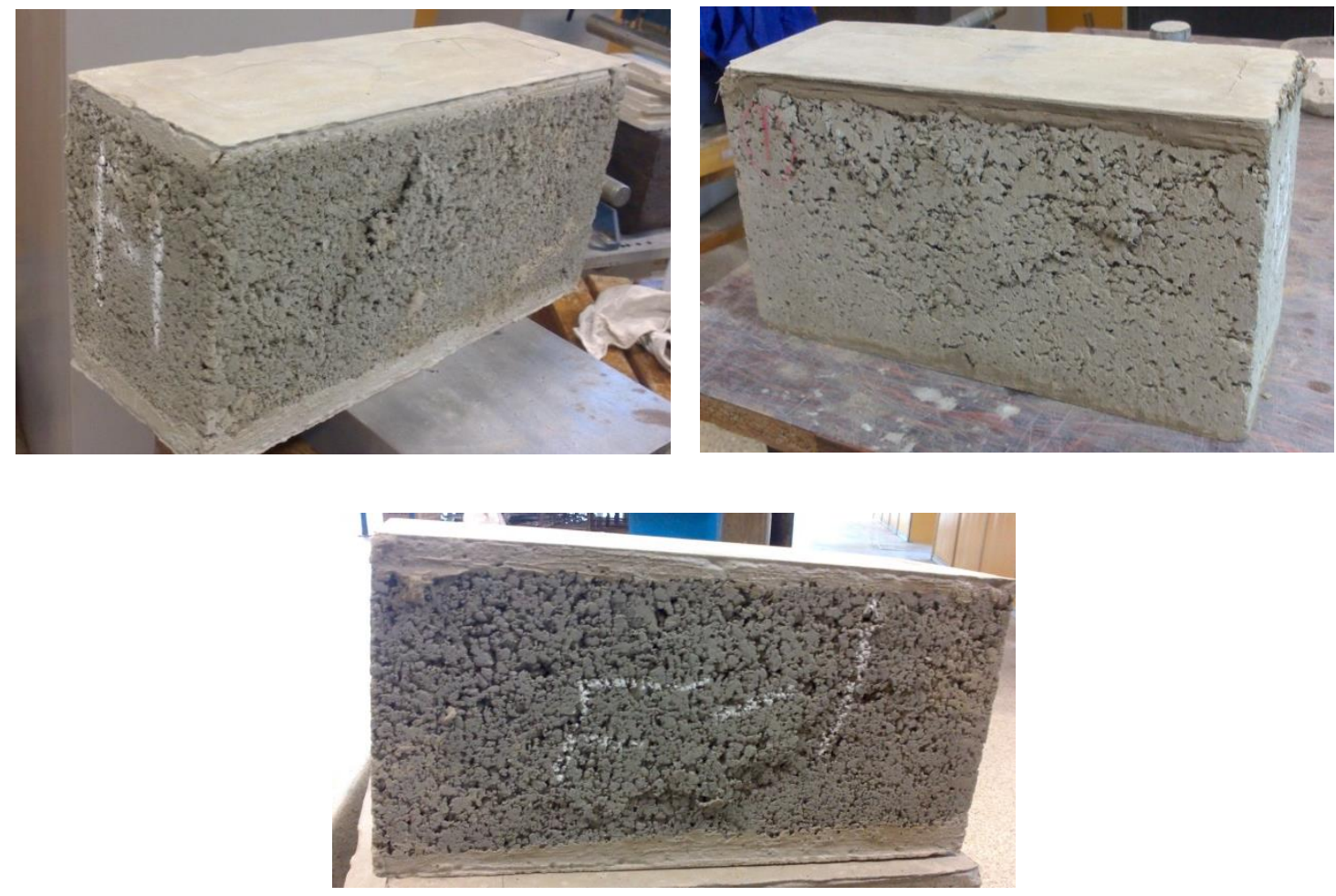

Figura 6.7 - Ruptura dos blocos com adição de fibra (Fonte: autor)

As unidades reforçadas, mesmo quando já rompidas, mantiveram suas partes unidas pelas fibras, não perdendo sua continuidade e tornando a ruptura um processo progressivo. Segundo Campos (2008), isso comprova o papel das fibras como materiais capazes de unir as faces das fissuras. Elas conferem ao material certa capacidade, embora pequena, de carregamento após a fissuração que pode contribuir para o aumento da tenacidade do elemento.

\subsection{Resistência à compressão da argamassa de assentamento}

Os prismas a as pequenas paredes análogos ao traço 1:15 foram feitos com a argamassa tipo (iii) de baixa resistência (A1) e para os elementos do traço 1:10 e 1:6 foram escolhidas duas argamassa (B1 e B2, respectivamente) com diferentes resistência que correspondem ao tipo (ii) de média resistência, conforme foi explicado no Capítulo 4.

A Tabela 6.16 mostra os intervalos de confiança da média, desvio padrão e coeficiente de variação da resistência à compressão das argamassas $\left(f_{a}\right)$, assim como a relação entre os valores de resistência das argamassas e das unidades. É importante apontar que como os valores de resistência foram dados em intervalos tanto para os blocos como para as argamassas para uma confiabilidade de $95 \%$, a relação $\mathrm{f}_{\mathrm{a}} / \mathrm{f}_{\mathrm{bm}}$ será dada também em uma faixa com a mesma confiabilidade. O valor correspondente à relação mínima de $\mathrm{f}_{\mathrm{a}} / \mathrm{f}_{\mathrm{bm}}$ é dado pela divisão do limite inferior da resistência da argamassa vezes o limite superior da resistência 
dos blocos e o valor correspondente à relação máxima de $\mathrm{f}_{\mathrm{a}} / \mathrm{f}_{\mathrm{bm}}$ é o limite superior da tensão da argamassa vezes o limite inferior dos blocos. Dessa forma foram obtidos os valores extremos do intervalo de confiança da relação resistência argamassa/bloco.

Tabela 6.16 - Resistência à compressão das argamassas (Fonte: autor)

\begin{tabular}{|c|c|c|c|c|c|c|c|c|c|}
\hline \multirow{3}{*}{ Tipo de Bloco } & \multirow{3}{*}{$\begin{array}{c}\text { Tipo de } \\
\text { argamassa }\end{array}$} & \multicolumn{6}{|c|}{ Resistência à compressão das argamassas (MPa) } & \multirow{2}{*}{\multicolumn{2}{|c|}{$\mathrm{fa} / \mathrm{fbm}(\%)$}} \\
\hline & & \multicolumn{2}{|c|}{ Média (fa) } & \multicolumn{2}{|c|}{ Sd } & \multicolumn{2}{|c|}{$\mathrm{CV}(\%)$} & & \\
\hline & & Inferior & Superior & Inferior & Superior & Inferior & Superior & Mínima & Máxima \\
\hline BE1:15-Ref & $\mathrm{A} 1$ & 3,53 & 3,67 & 0,24 & 0,56 & 6,80 & 15,26 & 51 & 59 \\
\hline BE1:15-5\%P.L & A1 & 3,56 & 3,63 & 0,24 & 0,42 & 6,74 & 11,57 & 57 & 68 \\
\hline BE1:10-Ref & B1 & 6,45 & 6,54 & 0,45 & 0,72 & 6,98 & 11,01 & 52 & 61 \\
\hline BE1:10-5\%P.L & B1 & 6,37 & 6,44 & 0,48 & 0,67 & 7,54 & 10,40 & 50 & 58 \\
\hline BE1:10-F1 & B1 & 6,31 & 6,39 & 0,31 & 0,56 & 4,91 & 8,76 & 74 & 83 \\
\hline BE1:10-F2 & B1 & 6,29 & 6,34 & 0,29 & 0,59 & 4,61 & 9,31 & 65 & 71 \\
\hline BE1:6-Ref & B2 & 7,20 & 7,41 & 0,34 & 0,61 & 4,72 & 8,23 & 47 & 52 \\
\hline BE1:6-10\%P.L & B2 & 7,26 & 7,45 & 0,28 & 0,57 & 3,86 & 7,65 & 46 & 51 \\
\hline
\end{tabular}

Segundo Barbosa (2004) para acomodar as pequenas deformações da alvenaria, a argamassa deve ser menos rígida que os blocos e, consequentemente, menos resistente. Hendry (2001) comenta que a resistência à compressão da argamassa não é um fator crítico. Os ensaios conduzidos pelo referido pesquisador mostraram que com uma diminuição da resistência da argamassa em 50\% obteve-se uma redução de apenas $12,5 \%$ na resistência da parede. De acordo com Ramalho e Corrêa (2003), a resistência da argamassa é importante apenas quando é inferior a $30 \%$ ou $40 \%$ da resistência do bloco. Os autores citam que argamassas com resistência de até $50 \%$ da resistência do bloco dificilmente afetam a resistência das paredes. Com base nos resultados obtidos e nas recomendações dos pesquisadores, todas as relações argamassa/bloco da Tabela 6.16 podem-se considerar aceitáveis. As menores relações correspondem aos elementos com o traço 1:6, com valores entre $46 \%$ (mínimo) e 52\% (máximo). Entretanto acredita-se que a argamassa não represente um fator limitante no desempenho mecânico dos elementos de alvenaria, segundo a experiência dos autores citados anteriormente.

\subsection{Resistência à compressão dos prismas}

A avaliação da resistência à compressão dos prismas tem como objetivo estudar se os pós residuais e a fibra de sisal incorporados na mistura influenciam na resistência à compressão, módulo de deformação e modo de ruptura comparativamente aos prismas de referência. Foram ensaiados, aos 28 dias, dez prismas para cada série de blocos, totalizando 60 elementos. 


\subsubsection{Prismas produzidos com os pós residuais}

Os intervalos de confiança da média, desvio padrão e coeficiente de variação da resistência à compressão dos prismas com os pós residuais, assim como os intervalos do fator eficiência prisma/bloco $\left(\mathrm{f}_{\mathrm{p}} / \mathrm{f}_{\mathrm{bm}}\right)$ para uma confiabilidade de $95 \%$ encontram-se na Tabela 6.17. A mesma análise feita para a relação resistência argamassa/bloco foi feita para o fator de eficiência prisma/bloco e este será dado também em uma faixa para uma mesma confiabilidade. $\mathrm{O}$ valor correspondente ao fator eficiência mínimo é produto da divisão do limite inferior da resistência dos prismas vezes o limite superior da resistência dos blocos e o valor correspondente à eficiência máxima é o limite superior da tensão dos prismas vezes o limite inferior dos blocos. Dessa forma foram obtidos os valores extremos do intervalo do fator eficiência prisma/bloco.

Tabela 6.17 - Resistência à compressão dos prismas com os pós residuais (Fonte: autor)

\begin{tabular}{|c|c|c|c|c|c|c|c|c|}
\hline \multirow{3}{*}{$\begin{array}{l}\text { Tipo de } \\
\text { Prisma }\end{array}$} & \multicolumn{6}{|c|}{ Resistência à compressão (MPa) } & \multirow{2}{*}{\multicolumn{2}{|c|}{$\begin{array}{c}\text { Fator de } \\
\text { Eficiência }\left(f_{p} / f_{b m}\right)\end{array}$}} \\
\hline & \multirow{2}{*}{\multicolumn{2}{|c|}{$\begin{array}{c}\text { Média }\left(f_{p}\right) \\
\text { Inferior Superior }\end{array}$}} & \multicolumn{2}{|c|}{ Sd } & \multicolumn{2}{|c|}{ CV (\%) } & & \\
\hline & & & Inferior & Superior & Inferior & Superior & Mínimo & Máximo \\
\hline$\overline{\text { PR1:15-Ref }}$ & 5,13 & 5,57 & 0,26 & 0,61 & 5,12 & 10,96 & 0,74 & 0,89 \\
\hline PR1:15-5\%P.L & 4,16 & 4,68 & 0,26 & 0,54 & 6,21 & 11,54 & 0,67 & 0,88 \\
\hline PR1:10-Ref & 8,74 & 9,42 & 0,40 & 0,86 & 4,59 & 9,11 & 0,71 & 0,87 \\
\hline PR1:10-5\%P.L & 9,23 & 9,98 & 0,66 & 1,25 & 7,12 & 12,57 & 0,72 & 0,90 \\
\hline PR1:6-Ref & 10,84 & 11,63 & 0,56 & 1,15 & 5,12 & 9,89 & 0,71 & 0,81 \\
\hline PR1:6-10\%P.L & 11,07 & 11,76 & 0,76 & 1,30 & 6,84 & 11,03 & 0,69 & 0,80 \\
\hline
\end{tabular}

De forma geral os prismas tiveram o mesmo comportamento mecânico que os blocos e a faixa do coeficiente de variação foi aceitável, inferior a 15\%. Os prismas pertencentes aos traços 1:10 e 1:6 apresentaram intervalos com valores superiores aos elementos de referência produto do correto empacotamento entre as partículas do pó orgânico e do cimento, já para o traço 1:15 a resistência do prisma com o pó residual foi menor com relação ao prisma controle. Com relação ao fator de eficiência prisma/bloco, os intervalos variaram entre 0,67 (valor mínimo) e 0,90 (valor máximo). Alguns pesquisadores, como Freitas (2006) obteve um fator de eficiência entre 0,59 e 0,67 utilizando-se argamassa média e Romagna (2000) alcançou fatores de eficiência situados entre 0,57 e 0,70 para blocos com resistência à compressão entre $10 \mathrm{MPa}$ e $17 \mathrm{MPa}$. Segundo Ramalho e Corrêa (2003) normalmente os valores de eficiência prisma/bloco, para a prática corrente no Brasil, variam de 0,5 a 0,9 no caso dos blocos de concreto. O valor de eficiência dos prismas da presente pesquisa encontrase dentro desse intervalo. Os prismas que tiveram o intervalo do fator de eficiência com valores mais baixos foram os construídos com blocos de traço rico 1:6 com 10\% de pó 
residual orgânico. Realmente, é sabido que a eficiência tende a ser menor quanto maior a resistência do bloco, como ocorreu neste caso.

Na Figura 6.8 pode ser observado o diagrama de caixa dos valores médios da resistência de cada um dos prismas para os diferentes traços.

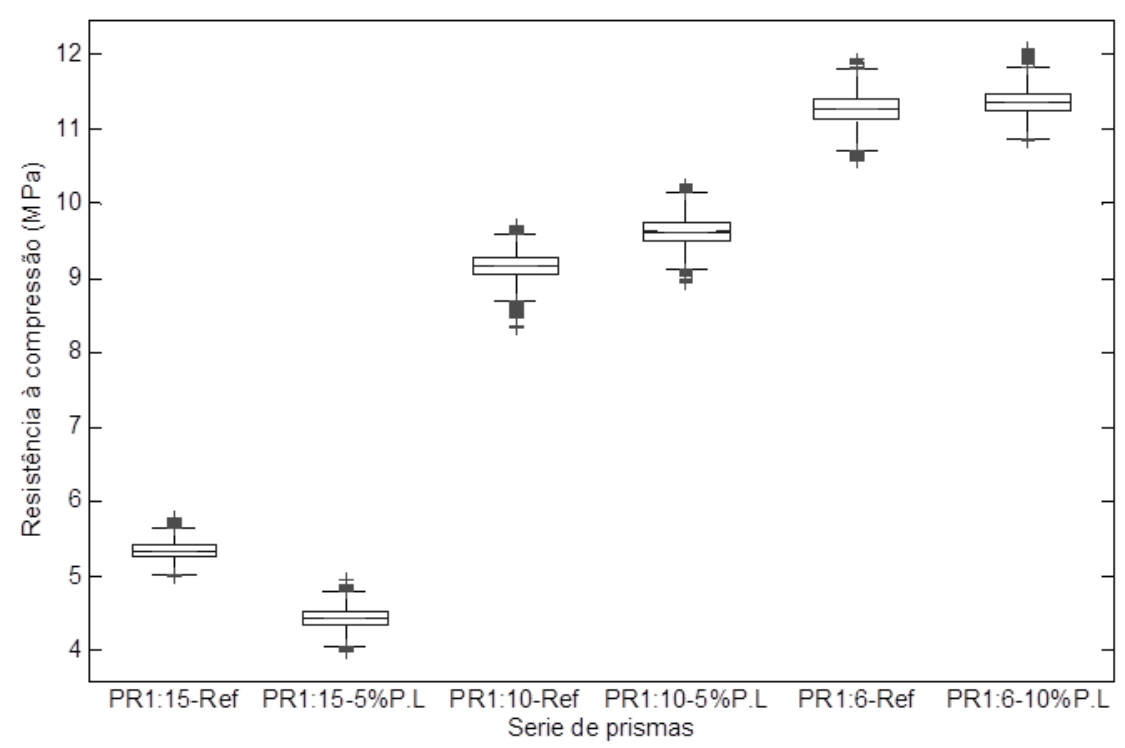

Figura 6.8 - Diagrama de caixa para os dados da resistência à compressão dos prismas com os pós residuais (Fonte: autor)

Pode-se comprovar como os prismas PR1:15-5\%P.L apresentaram menor resistência em relação ao prisma controle e os elementos do traço 1:6 tiveram praticamente a mesma resistência. A distribuição dos valores foi simétrica pela posição equidistante da mediana dentro das caixas exceto para o PR1:15-Ref onde a mediana ficou mais próxima ao primeiro quartil. Segundo as dimensões das caixas, não existe evidência de dispersão dos valores, sob o aspecto visual.

A probabilidade de que as hipóteses nulas sejam aceitas para os prismas com os pós residuais é expressa na Tabela 6.18 . 
Tabela 6.18 - Probabilidade de que as hipóteses nulas sejam aceitas para os prisma com os pós residuais (Fonte: autor)

\begin{tabular}{|c|c|c|c|c|c|c|}
\hline \multirow{2}{*}{ Traço 1:15 } & \multicolumn{3}{|c|}{ PR1:15-Ref } & \multicolumn{3}{|c|}{ PR1:15-5\% P.L } \\
\hline & $\mathbf{H}_{01}$ & $\mathrm{H}_{02}$ & $\mathbf{H}_{\mathbf{0 3}}$ & $\mathbf{H}_{01}$ & $\mathbf{H}_{02}$ & $\mathbf{H}_{\mathbf{0 3}}$ \\
\hline PR1:15-Ref & 0 & 100 & 0 & 0 & 0,21 & 99,74 \\
\hline PR1:15-5\%P.L & 99,74 & 0,21 & 0 & 0 & 100 & 0 \\
\hline \multirow{2}{*}{ Traço 1:10 } & \multicolumn{3}{|c|}{ PR1:10-Ref } & \multicolumn{3}{|c|}{ PR1:10-5\%P.L } \\
\hline & $\mathbf{H}_{01}$ & $\mathbf{H}_{02}$ & $\mathbf{H}_{\mathbf{0 3}}$ & $\mathbf{H}_{01}$ & $\mathbf{H}_{02}$ & $\mathbf{H}_{03}$ \\
\hline$\overline{\text { PR1:10-Ref }}$ & 0 & 100 & 0 & 43,65 & 56,11 & 0,24 \\
\hline PR1:10-5\%P.L & 0,24 & 56,11 & 43,65 & 0 & 100 & 0 \\
\hline \multirow{2}{*}{ Traço 1:6 } & \multicolumn{3}{|c|}{ PR1:6-Ref } & \multicolumn{3}{|c|}{ PR1:6-10\% P.L } \\
\hline & $\mathbf{H}_{01}$ & $\mathrm{H}_{02}$ & $\mathbf{H}_{\mathbf{0 3}}$ & $\mathbf{H}_{01}$ & $\mathbf{H}_{02}$ & $\mathbf{H}_{03}$ \\
\hline$\overline{\text { PR1:6-Ref }}$ & 0 & 100 & 0 & 2,88 & 93,52 & 3,60 \\
\hline PR1:6-10\%P.L & 3,60 & 93,52 & 2,88 & 0 & 100 & 0 \\
\hline
\end{tabular}

Conforme a Tabela 6.18, pode-se confirmar estatisticamente que, para o traço 1:15 existe 99,74\% de probabilidade que a resistência média do prisma com 5\% de pó de resíduo orgânico seja inferior ao prisma de referência e 0,21\% que sejam iguais. Já para o traço 1:10, os elementos com adição do resíduo apresentaram $56,11 \%$ de probabilidade que a resistência seja igual ao prisma controle e $43,65 \%$ que seja superior. Com relação ao traço 1:6, o prisma com $10 \%$ de resíduo teve $2,88 \%$ de probabilidade de apresentar maior resistência comparada ao prisma de referência e $93,52 \%$ de serem iguais. Segundo os resultados da Tabela 6.18 é possível confirmar estatisticamente que os prismas com adição de pó de resíduo orgânico apresentaram pior desempenho no traço 1:15 e bom desempenho no traço 1:10. Já considerando o traço 1:6 as propriedades mecânicas se mantiveram estatisticamente iguais com relação aos elementos de referência.

\subsubsection{Prismas com adição de fibra de sisal}

Na Tabela 6.19 são apresentados os intervalos de confiança da média, desvio padrão e coeficiente de variação da resistência à compressão, assim como os intervalos do fator eficiência prisma/bloco $\left(\mathrm{f}_{\mathrm{p}} / \mathrm{f}_{\mathrm{bm}}\right)$ para uma confiabilidade de $95 \%$.

Tabela 6.19 - Resistência à compressão dos prismas com adição de fibra de sisal (Fonte: autor)

\begin{tabular}{|c|c|c|c|c|c|c|c|c|}
\hline \multirow{3}{*}{$\begin{array}{l}\text { Tipo de } \\
\text { Prisma }\end{array}$} & \multicolumn{6}{|c|}{ Resistência à compressão (MPa) } & \multirow{2}{*}{\multicolumn{2}{|c|}{$\begin{array}{c}\text { Fator de } \\
\text { Eficiência }(\mathbf{f p} / \mathrm{fbm})\end{array}$}} \\
\hline & \multicolumn{2}{|c|}{ Média $\left(f_{p}\right)$} & \multicolumn{2}{|c|}{ Sd } & \multicolumn{2}{|c|}{$\mathrm{CV}(\%)$} & & \\
\hline & Inferior & Superior & Inferior & Superior & Inferior & Superior & Mínimo & Máximo \\
\hline R1:1 & 8,74 & 9,42 & 0,40 & 0,86 & 4,59 & 9,11 & 0,71 & 0,87 \\
\hline PR1:10-F & 6,19 & 6,81 & 0,29 & 0,77 & 4,68 & 11,31 & 0,73 & 0,88 \\
\hline PR1:10-F2 & 7,39 & 7,93 & 0,28 & 0,69 & 3,79 & 8,70 & 0,76 & 0,89 \\
\hline
\end{tabular}


Nota-se que como os prismas reforçados com as fibras apresentaram pior desempenho com relação aos prismas de referência e os elementos PR1:10-F2 apresentaram maior resistência à compressão comparados com os prismas PR1:10-F1. Com relação ao fator de eficiência prisma/bloco, os intervalos variaram entre 0,71 (valor mínimo) e 0,89 (valor máximo) considerando todos os elementos, sendo esses resultados coerentes com os valores de eficiência encontrados na literatura. Apesar dos prismas com adição de sisal terem alcançados menor resistência à compressão, alcançaram maior eficiência prisma/bloco com relação aos prismas sem adição da fibra.

Na Figura 6.9 é mostrado o diagrama de caixa dos valores médios da resistência de cada um dos prismas para uma melhor compreensão dos resultados. Por meio desse diagrama pode-se comprovar que o comportamento mecânico dos prismas está de acordo com os resultados apresentados na Tabela 6.19. De forma geral, os dados dos três grupos apresentaram uma distribuição simétrica e não existe evidência de dispersão dos mesmos, sob o aspecto visual.

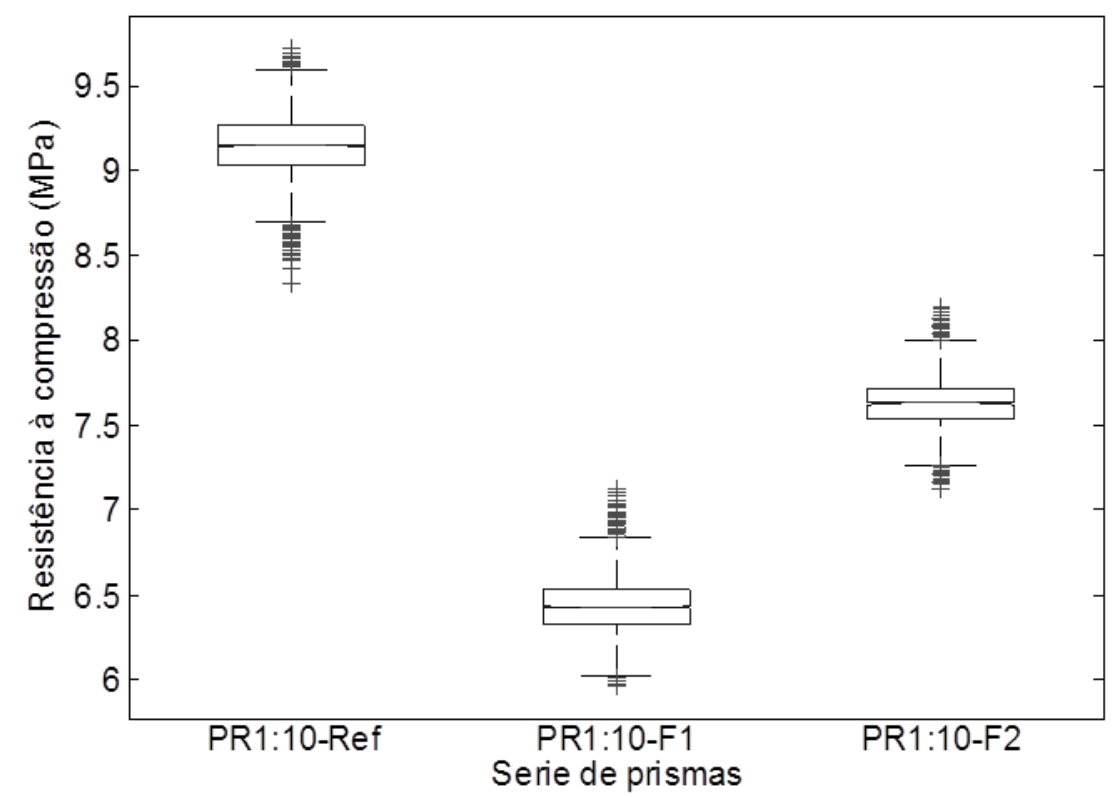

Figura 6.9 - Diagrama de caixa para os dados da resistência à compressão dos prismas com fibra de sisal (Fonte: autor)

A probabilidade de que as hipóteses nulas sejam aceitas para os prismas com e sem adição de fibra de sisal encontra-se na Tabela 6.20. 
Tabela 6.20 - Probabilidade de que as hipóteses nulas sejam aceitas para os prismas com fibra de sisal (Fonte: autor)

\begin{tabular}{|c|c|c|c|c|c|c|c|c|c|}
\hline \multirow{2}{*}{$\begin{array}{l}\text { Tipo de } \\
\text { Prisma }\end{array}$} & \multicolumn{3}{|c|}{ PR1:10-Ref } & \multicolumn{3}{|c|}{ PR1:10-F1 } & \multicolumn{3}{|c|}{ PR1:10-F2 } \\
\hline & $\mathbf{H}_{01}$ & $\mathbf{H}_{02}$ & $\mathbf{H}_{03}$ & $\mathbf{H}_{01}$ & $\mathbf{H}_{02}$ & $\mathbf{H}_{03}$ & $\mathbf{H}_{01}$ & $\mathrm{H}_{02}$ & $\mathbf{H}_{\mathbf{0 3}}$ \\
\hline PR1:10-Ref & 0 & 100 & 0 & 0 & 0 & 100 & 0 & 0 & 100 \\
\hline PR1:10-F1 & 100 & 0 & 0 & 0 & 100 & 0 & 100 & 0 & 0 \\
\hline PR1:10-F2 & 100 & 0 & 0 & 0 & 0 & 100 & 0 & 100 & 0 \\
\hline
\end{tabular}

O prisma de referência quando comparado com os prismas reforçados, teve $100 \%$ de probabilidade de a hipótese nula $\mathrm{H}_{03}\left(\mathrm{u}_{1}>\mathrm{u}_{2}\right)$ ser aceita, portanto, existe $100 \%$ de possibilidade que sua resistência seja superior com relação aos elementos com adição de sisal para um nível de significância de 5\%. Já o prisma PR1:10-F2 (fila 3) quando comparado com o bloco BE1:10-F1 (coluna 2) apresentou $100 \%$ de probabilidade de a hipótese nula $\mathrm{H}_{03}\left(\mathrm{u}_{1}>\right.$ $\mathrm{u}_{2}$ ) ser aceita. Em outras palavras, isso significa que $\mathrm{u}_{1}$ (resistência de BE1:10-F1) é estatisticamente superior $\mathrm{a} \mathrm{u}_{2}$ (resistência de BE1:10-F2), portanto o prisma com a matriz modificada teve melhor desempenho mecânico que o prisma com o cimento Portland ARI.

\subsection{Modos de ruptura dos prismas}

A Figura 6.10 apresenta a forma de ruptura dos prismas de referência e com adição do pó residual orgânico.

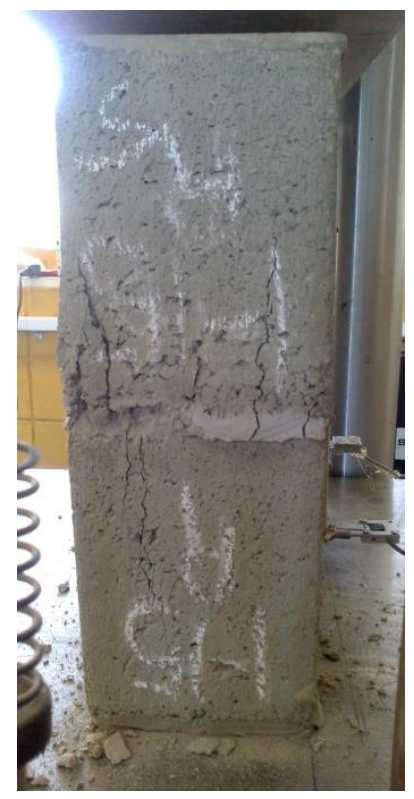

(a)

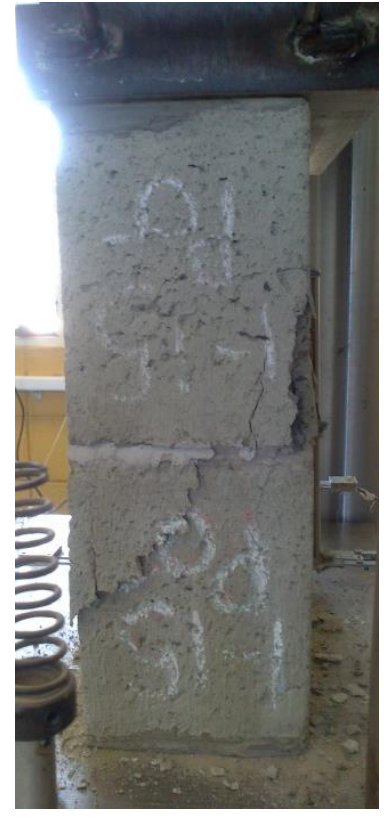

(b)

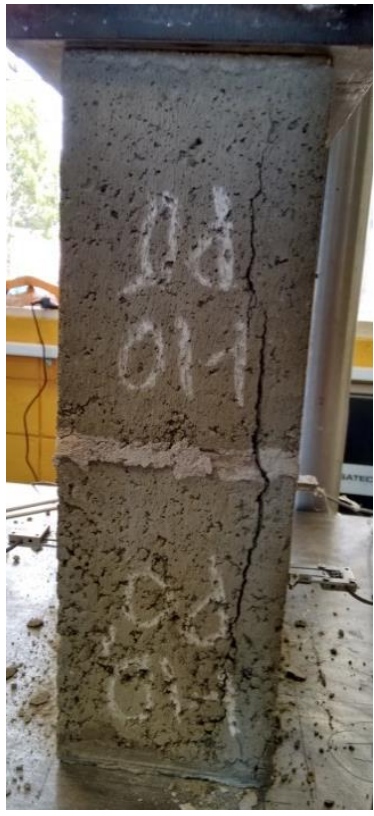

(c) 


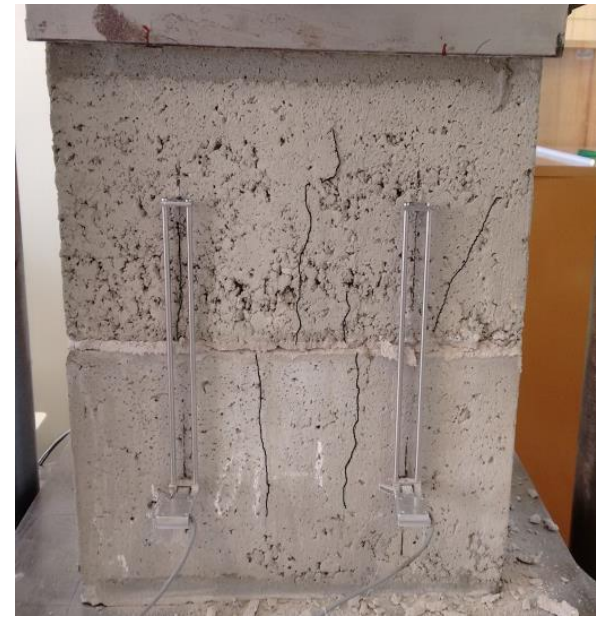

(d)

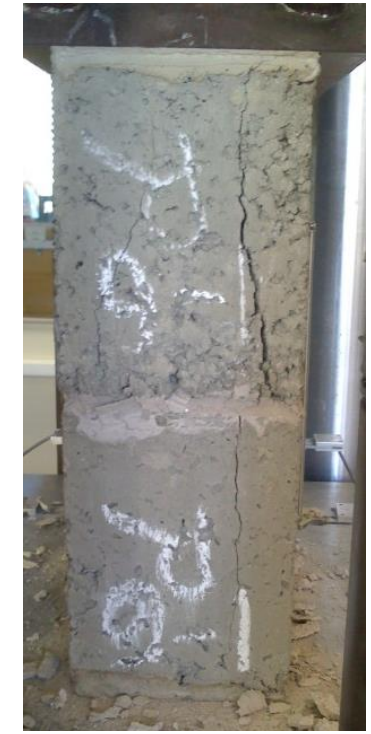

(e)

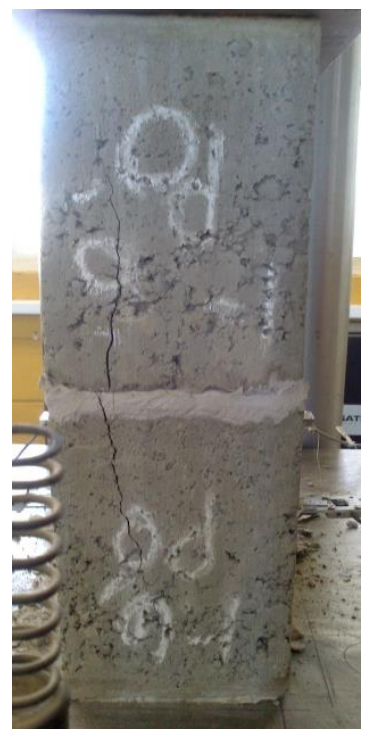

(f)

Figura 6.10 - Ruptura típica dos prismas sob compressão: (a) PR1:15-Ref, (b) PR1:15-5\%P.L, (c) PR1:10-5\% P.L, (d) PR1:10-Ref, (e) PR1:6-Ref e (f) PR1:6-10\% P.L (Fonte: autor)

$\mathrm{Na}$ maioria dos casos a ruptura ocorreu por meio do desenvolvimento de fissuras verticais ao longo dos septos laterais. Elas iniciaram próximo às juntas de argamassa e a partir daí se espalharam por toda a altura do elemento. Foi observado também o esfacelamento da parte externa das paredes dos blocos como mostra o elemento PR1:10-Ref. Segundo Mohamad et al. (2009), essas rupturas são devidas ao fato da argamassa ser menos rígida que os blocos. Portanto, ela tem a tendência de deformar-se mais do que as unidades e surgem assim tensões de tração transversais ao eixo de compressão próximas da junta.

A Figura 6.11 ilustra o modo de ruptura dos prismas reforçados com a fibra de sisal. Para alvenaria de blocos de concreto a ruptura normalmente ocorre devido à ruptura por tração da unidade. Dessa maneira, a função das fibras existentes nos blocos de concreto seria a de permitir as transferências dos esforços de tração, diminuindo a propagação de fissuras e controlando suas aberturas. Esse tipo de comportamento foi observado nos prismas com adição de fibras em que fissuras surgiram nas paredes dos blocos mais tarde, ou seja, a relação entre a carga da primeira fissura e a carga última foi de 89,22\% (em média). Para os prismas sem fibras esta relação foi menor de 73,19\% (em média). Além disso, as fibras mantiveram as partes do material unidas mesmo após a ruptura dos elementos. 


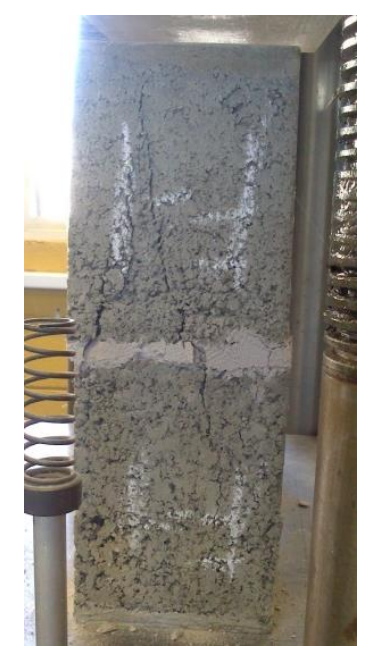

(a)

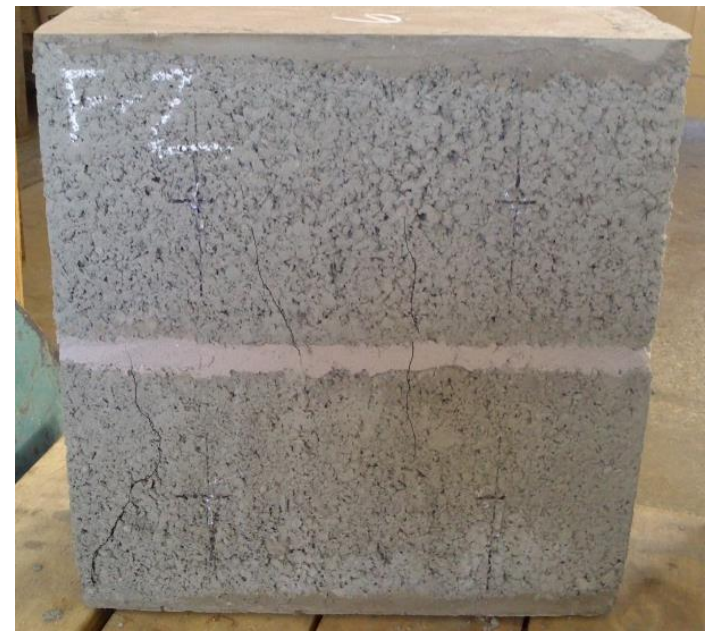

(b)

Figura 6.11 - Ruptura dos prismas com fibras sob compressão: (a) PR1:10-F1 e (b) PR1:10-F2 (Fonte: autor)

\subsection{Módulo de deformação dos prismas}

\subsubsection{Prismas produzidos com os pós residuais}

Os resultados dos intervalos de confiança do módulo de deformação, desvio padrão e coeficiente de variação dos prismas com os pós residuais referidos à área bruta são apresentados na Tabela 6.21. Também pode-se observar os intervalos da relação entre o módulo de deformação e a resistência média à compressão dos prismas $\left(\mathrm{E}_{\mathrm{p}} / \mathrm{f}_{\mathrm{p}}\right)$ contendo os valores extremos da faixa para uma confiabilidade de $95 \%$.

Tabela 6.21 - Módulo de deformação dos prismas com os pós residuais (Fonte: autor)

\begin{tabular}{|c|c|c|c|c|c|c|c|c|}
\hline \multirow{3}{*}{$\begin{array}{l}\text { Tipo de } \\
\text { Prisma }\end{array}$} & \multicolumn{6}{|c|}{ Módulo de deformação (MPa) } & \multirow{2}{*}{\multicolumn{2}{|c|}{ Relação Ep/fp }} \\
\hline & \multicolumn{2}{|c|}{ Média $\left(\mathbf{E}_{\mathbf{p}}\right)$} & \multicolumn{2}{|c|}{ Sd } & \multicolumn{2}{|c|}{ CV (\%) } & & \\
\hline & Inferior & $\overline{\text { Superior }}$ & Inferior & $\overline{\text { Superior }}$ & Inferior & Superior & Mínima & Máxima \\
\hline$\overline{\text { PR1:15-Ref }}$ & 5041 & 6289 & 601 & 1093 & 12 & 17 & 905 & 1226 \\
\hline PR1:15-5\%P.L & 4079 & 5051 & 554 & 951 & 14 & 19 & 872 & 1214 \\
\hline PR1:10-Ref & 8401 & 10026 & 805 & 1636 & 10 & 16 & 892 & 1147 \\
\hline PR1:10-5\%P.L & 9016 & 11029 & 1006 & 2054 & 11 & 19 & 903 & 1195 \\
\hline PR1:6-Ref & 10479 & 13240 & 1492 & 2589 & 14 & 20 & 901 & 1221 \\
\hline PR1:6-10\%P.L & 11150 & 14070 & 1487 & 2649 & 13 & 19 & 948 & 1271 \\
\hline
\end{tabular}

Analisando-se os resultados, nota-se que houve redução da rigidez dos prismas com adição de 5\% de pó de resíduo orgânico comparados com os prismas de referência para o traço 1:15. Já os prismas construídos com blocos que apresentaram na mistura proporções de pó de resíduo orgânico de 5 e 10\% para os traços 1:10 e 1:6, respectivamente, tiveram maior módulo de deformação quando comparados aos elementos de referência. Esses resultados 
eram de certa forma esperados já que resistências maiores tendem a produzir uma maior rigidez.

Os intervalos da relação entre o módulo e a resistência do prisma variaram na faixa de 872 (valor mínimo) e 1226 (valor máximo). A BS 5628-2: 2000 estima esse parâmetro igual a 900, o manual técnico da ABCI (1990) apresenta valores em torno de 1000 e Drysdale e Khattab (1995) alcançaram uma relação igual a 1061. Assim, os resultados da relação módulo/resistência à compressão dos prismas da presente pesquisa são coerentes com esses valores encontrados na literatura. Entretanto, os valores obtidos nesta pesquisa são ligeiramente maiores que o especificado na NBR 15961- 1: 2011, igual a 800.

As curvas tensão vs deformação de cada série dos prismas foram traçadas para uma melhor visualização dos resultados (Figura 6.12). Como os resultados de tensão média dos prismas foram expressos por meio de intervalos de confiança, é interessante apresentar, além das curvas de cada um dos dez prismas ensaiados, uma banda de confiança representada por uma curva superior e outra inferior obtidas com a aplicação da técnica do Bootstrap. Desse modo pode-se dizer que existe $95 \%$ de probabilidade de que a curva tensão $v s$ deformação da população encontre-se dentro dessa banda.
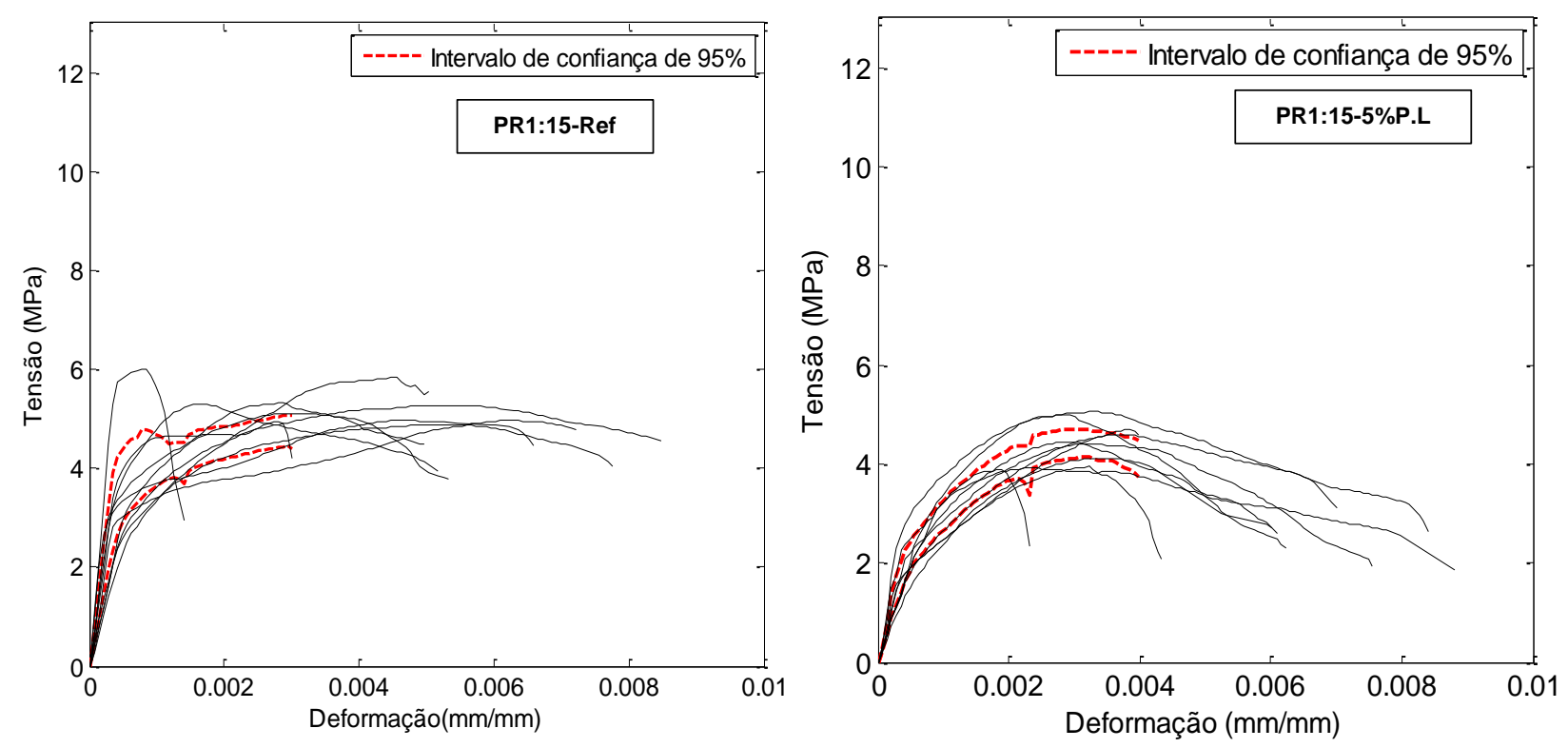

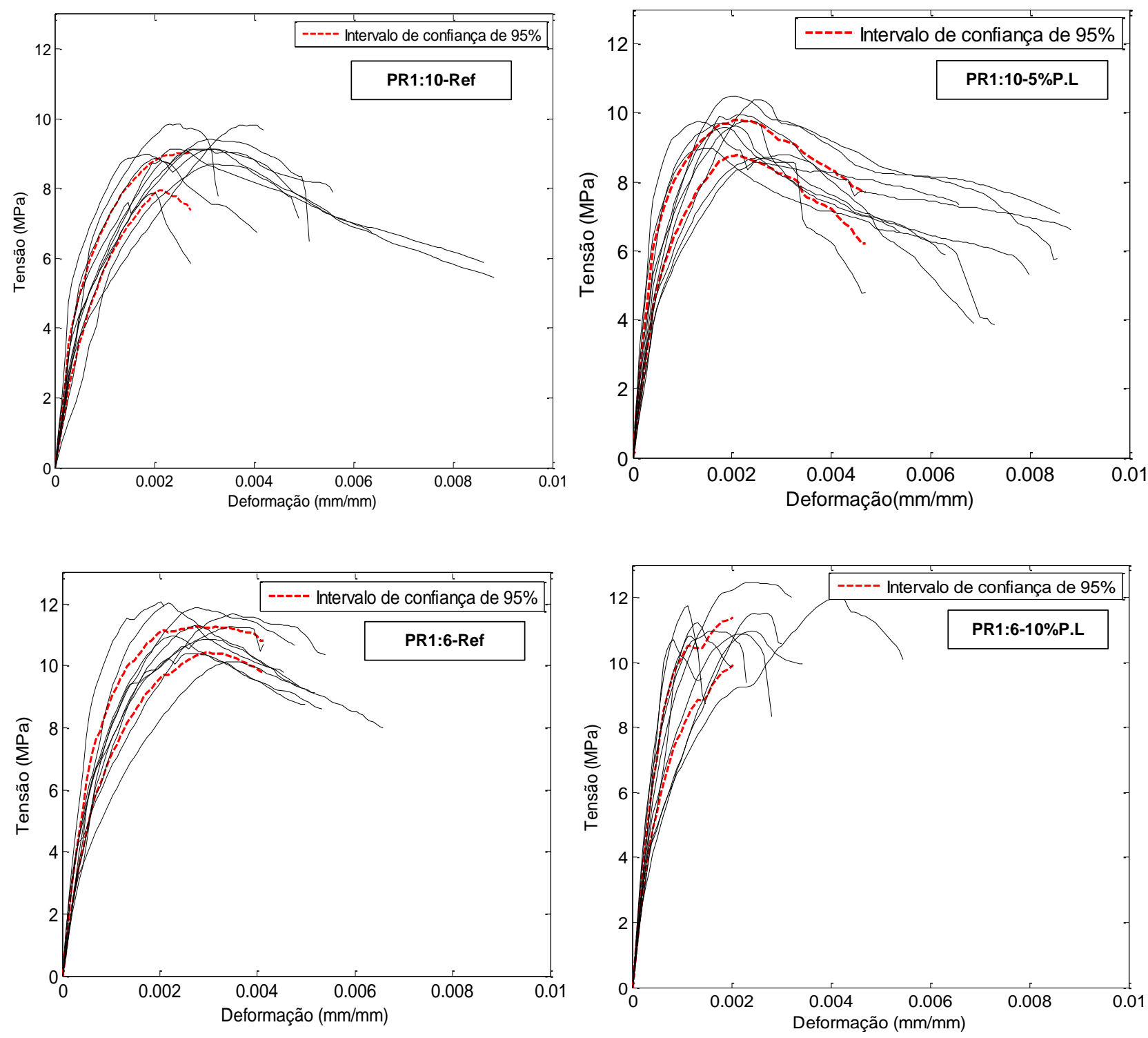

Figura 6.12 - Curvas tensão vs deformação dos prismas com os pós residuais (Fonte: autor)

\subsubsection{Prismas com adição de fibra de sisal}

Os resultados dos intervalos de confiança do módulo de deformação, desvio padrão e coeficiente de variação dos prismas com adição de fibra de sisal referidos à área bruta são apresentados na Tabela 6.22. Também podem ser observados os intervalos da relação entre o módulo de deformação e a resistência média à compressão dos prismas $\left(\mathrm{E}_{\mathrm{p}} / \mathrm{f}_{\mathrm{p}}\right)$ contendo os valores extremos da faixa para uma confiabilidade de $95 \%$. 
Tabela 6.22 - Módulo de deformação dos prismas com adição de fibra de sisal (Fonte: autor)

\begin{tabular}{|c|c|c|c|c|c|c|c|c|}
\hline \multirow{3}{*}{$\begin{array}{l}\text { Tipo de } \\
\text { Prisma }\end{array}$} & \multicolumn{6}{|c|}{ Módulo de deformação (MPa) } & \multirow{2}{*}{\multicolumn{2}{|c|}{ Relação Ep/fp }} \\
\hline & \multicolumn{2}{|c|}{ Média $\left(\mathbf{E}_{\mathrm{p}}\right)$} & \multicolumn{2}{|c|}{ Sd } & \multicolumn{2}{|c|}{$\mathrm{CV}(\%)$} & & \\
\hline & Inferior & $\overline{\text { Superior }}$ & Inferior & Superior & Inferior & Superior & $\overline{\text { Mínima }}$ & Máxima \\
\hline PR1:10-Ref & 8401 & 10026 & 805 & 1636 & 10 & 16 & 892 & 1147 \\
\hline PR1:10-F1 & 5795 & 6952 & 526 & 998 & 9 & 14 & 851 & 1123 \\
\hline PR1:10-F2 & 6907 & 8412 & 779 & 1372 & 11 & 16 & 871 & 1138 \\
\hline
\end{tabular}

Os prismas reforçados com fibras tiveram menor módulo de deformação que os prismas de referência. Segundo Zhou et al. (2013), os elementos com adição de fibras vegetais têm uma microestrutura menos densa tornando-os menos resistentes à compressão e, por conseguinte, apresentam uma rigidez inferior quando são comparados aos elementos de concreto comum. Por outro lado, os elementos PR1:10-F2 apresentaram maior módulo de deformação em referência aos prismas PR1:10-F1. O mesmo autor argumenta que devido à formação de maior quantidade de C-S-H, maior número de espaços vazios são preenchidos, aumentando assim a resistência e a rigidez da matriz. A relação módulo/resistência variou na faixa de 851 (valor mínimo) e 1147 (valor máximo). Mathew et al. (1999) cita ensaios realizados com prismas feitos com diferentes blocos, tipos de argamassas, padrões de assentamento e direções de carregamento, obtendo uma relação em torno de 1000.

As curvas tensão vs deformação dos prismas reforçados com as fibras foram traçadas para uma melhor visualização dos resultados e poderão ser comparadas com as curvas dos prismas de referência (Figura 6.13). Cada figura contém as curvas tensão vs deformação dos dez prismas ensaiados no laboratório e a curva superior e inferior do intervalo de confiança que foram traçadas usando a técnica do Bootstrap. Dessa forma, é possível inferir que a média populacional da tensão de cada elemento estudado encontra-se nessa banda de confiança para uma deformação específica com $95 \%$ de probabilidade. 

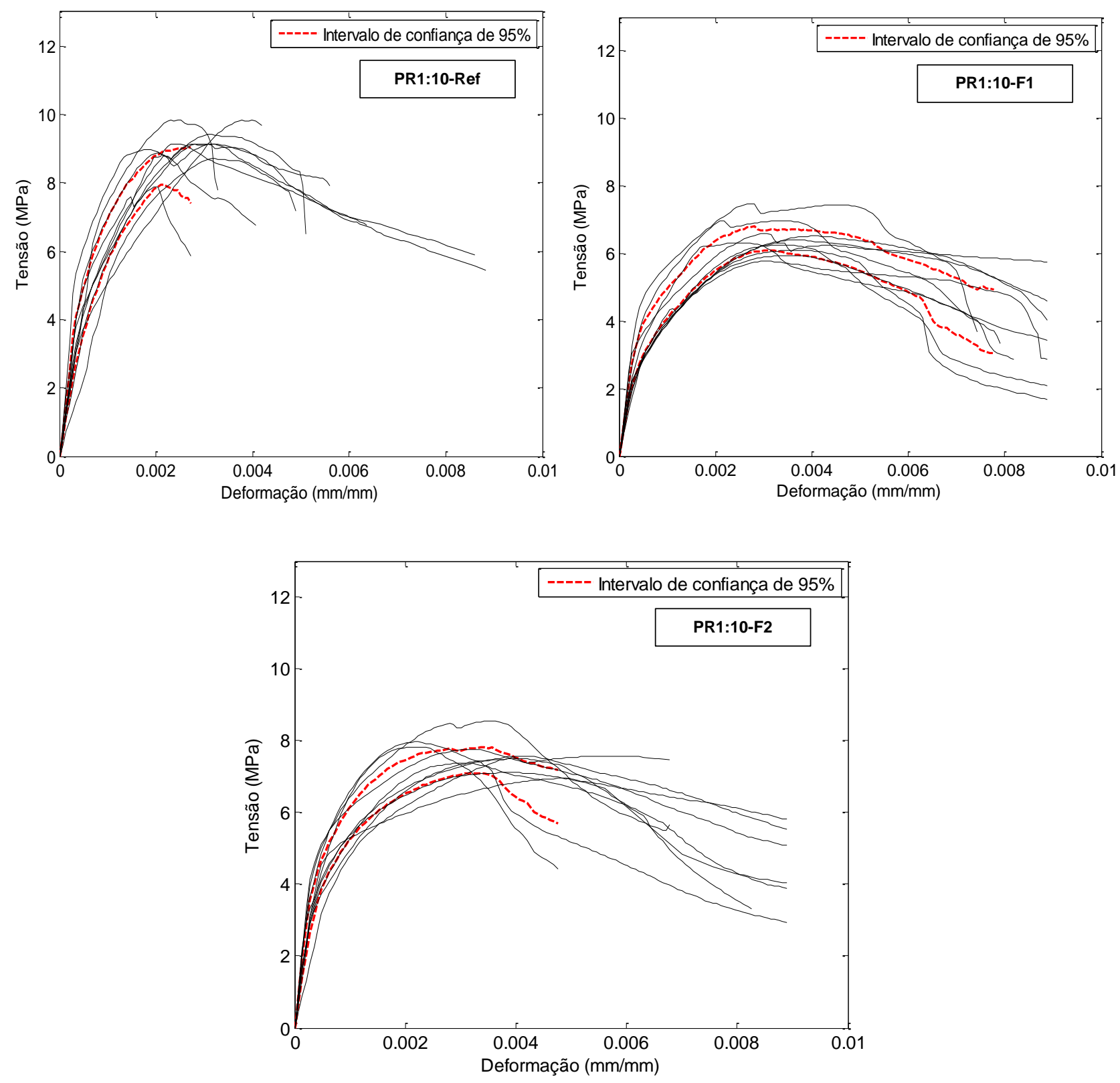

Figura 6.13 - Curvas tensão vs deformação dos prismas com adição de fibra de sisal (Fonte: autor)

Embora haja redução da resistência à compressão dos prismas com adição de fibra de sisal, percebe-se um ganho na capacidade de absorber deformações após terem alcançado a carga última. Isso mostra o papel das fibras, que torna os compósitos vantajosos em termos de ductilidade e capacidade de resistência após de fissuração da matriz. Segundo Savastano et al. (2009), as fissuras têm início em falhas do compósito e têm seu crescimento limitado pela presença das fibras. A partir do estágio em que essas fissuras começam a se juntar, a soma de seus efeitos exerce influência sobre a tenacidade em decorrência das grandes deformações sofridas pelo material. Tem-se, nesse caso, justificativa para o aumento de ductilidade conferida pelas fibras, uma vez que elas são responsáveis pela incorporação de vazios e 
descontinuidades que aumentam a energia absorvida durante a fissuração e ao mesmo tempo limitam a sua propagação.

\subsection{Resistência à compressão das pequenas paredes}

A avaliação da resistência à compressão das pequenas paredes tem como objetivo estudar se os pós residuais e a fibra de sisal incorporados na mistura influenciaram na resistência à compressão, módulo de deformação e modo de ruptura comparativamente aos elementos de referência.

Foram ensaiados, aos 28 dias, cinco paredes para cada série de blocos, totalizando 40 elementos. Foi utilizada a mesma argamassa empregada nos prismas.

\subsubsection{Pequenas paredes produzidas com os pós residuais}

Os intervalos de confiança da média, desvio padrão e coeficiente de variação da resistência à compressão das pequenas paredes com os pós residuais encontram-se na Tabela 6.23. Também são apresentados os valores extremos da relação entre a resistência média da parede e a resistência média dos blocos $\left(\mathrm{f}_{\mathrm{pp}} / \mathrm{f}_{\mathrm{bm}}\right)$ e da relação entre a resistência média da parede e a resistência média dos prismas $\left(f_{p p} / f_{p}\right)$, para uma confiabilidade de $95 \%$.

Tabela 6.23 - Resistência à compressão das pequenas paredes com os pós residuais (Fonte: autor)

\begin{tabular}{|c|c|c|c|c|c|c|c|c|c|c|}
\hline \multirow{3}{*}{$\begin{array}{l}\text { Tipo de Peq. } \\
\text { Parede }\end{array}$} & \multicolumn{6}{|c|}{ Resistência à compressão (MPa) } & \multirow{2}{*}{\multicolumn{2}{|c|}{$\begin{array}{c}\text { Fator de } \\
\text { Eficiência }(\mathbf{f} \text { pp/fbm) }\end{array}$}} & \multirow{2}{*}{\multicolumn{2}{|c|}{$\begin{array}{c}\text { Fator de } \\
\text { Eficiência }\left(\mathbf{f}_{p p /} / \mathbf{f}_{\mathrm{p}}\right)\end{array}$}} \\
\hline & \multicolumn{2}{|c|}{ Média (fpp) } & \multicolumn{2}{|c|}{ Sd } & \multicolumn{2}{|c|}{$\mathrm{CV}(\%)$} & & & & \\
\hline & Inferiol & Superior & Inferio & uperior & Inferic & Superior & Mínimo & Máximo & Mínimo & Máximo \\
\hline$P 1: 15$ & 3,18 & 3,95 & 0,16 & 0,57 & 5,03 & 14,39 & 0,46 & 0,63 & 0,57 & 0,77 \\
\hline PP1:15 & 2,88 & 3,59 & 0 , & & & 1 & 0,46 & 0,68 & 0,61 & 0,86 \\
\hline P1:10-Ref & 5,47 & 6,71 & 0 , & 1,09 & & 16,25 & 0,44 & 0,62 & 0,5 & 0,77 \\
\hline PP1:1 & 6,05 & 6,79 & 0,33 & 0 & & 1 & 0,47 & 0,61 & 0,61 & 0,74 \\
\hline PP1:6- & 6,75 & 7,36 & 0 , & 0,74 & 6 , & 10,08 & T T & 0,51 & 0,58 & 0,68 \\
\hline PP1:6-10\%P.L & 6,92 & 7,70 & 0,30 & 1,06 & 4,29 & 13,76 & 0,43 & 0,52 & 0,59 & 0,70 \\
\hline
\end{tabular}

Conforme era esperado pelos resultados obtidos nos blocos e nos prismas, os elementos pertencentes aos traços 1:10 e 1:6 apresentaram intervalos com valores superiores aos elementos de referência produto do correto empacotamento entre as partículas do pó orgânico e do cimento, já para o traço 1:15 a resistência das pequenas paredes com o pó residual foi menor com relação à parede controle.

Os intervalos do fator de eficiência parede/bloco $\left(\mathrm{f}_{\mathrm{pp}} / \mathrm{f}_{\mathrm{bm}}\right)$ variaram entre 0,43 (valor mínimo) e 0,68 (valor máximo). Romagna (2000) cita que para blocos vazados de concreto, esse fator varia de 0,40 a 0,60 considerando-se argamassas usuais. Freitas (2006) ensaiou 
pequenas paredes de $0,80 \times 0,80 \mathrm{~m}$, utilizou argamassa média e blocos de resistência 9,08 MPa e obteve um fator de eficiência de 0,65. Juste (2001) avaliou paredes de igual dimensão e compostas por blocos de 10,80 MPa e obteve valores de eficiência de 0,46. Os resultados encontrados neste estudo são coerentes com os encontrados na literatura sobre o tema. Já o fator de eficiência parede/prisma $\left(\mathrm{f}_{\mathrm{pp}} / \mathrm{f}_{\mathrm{p}}\right)$, os intervalos variaram entre 0,57 (valor mínimo) e 0,86 (valor máximo). Segundo Ramalho e Corrêa (2003), tomando-se um amplo conjunto de ensaios já realizados no Brasil, verifica-se que essa relação situa-se por volta de 0,7 tanto para blocos de concreto como para blocos cerâmicos.

$\mathrm{Na}$ Figura 6.14 pode ser observado o diagrama de caixa dos valores médios da resistência de cada uma das paredes para os diferentes traços.

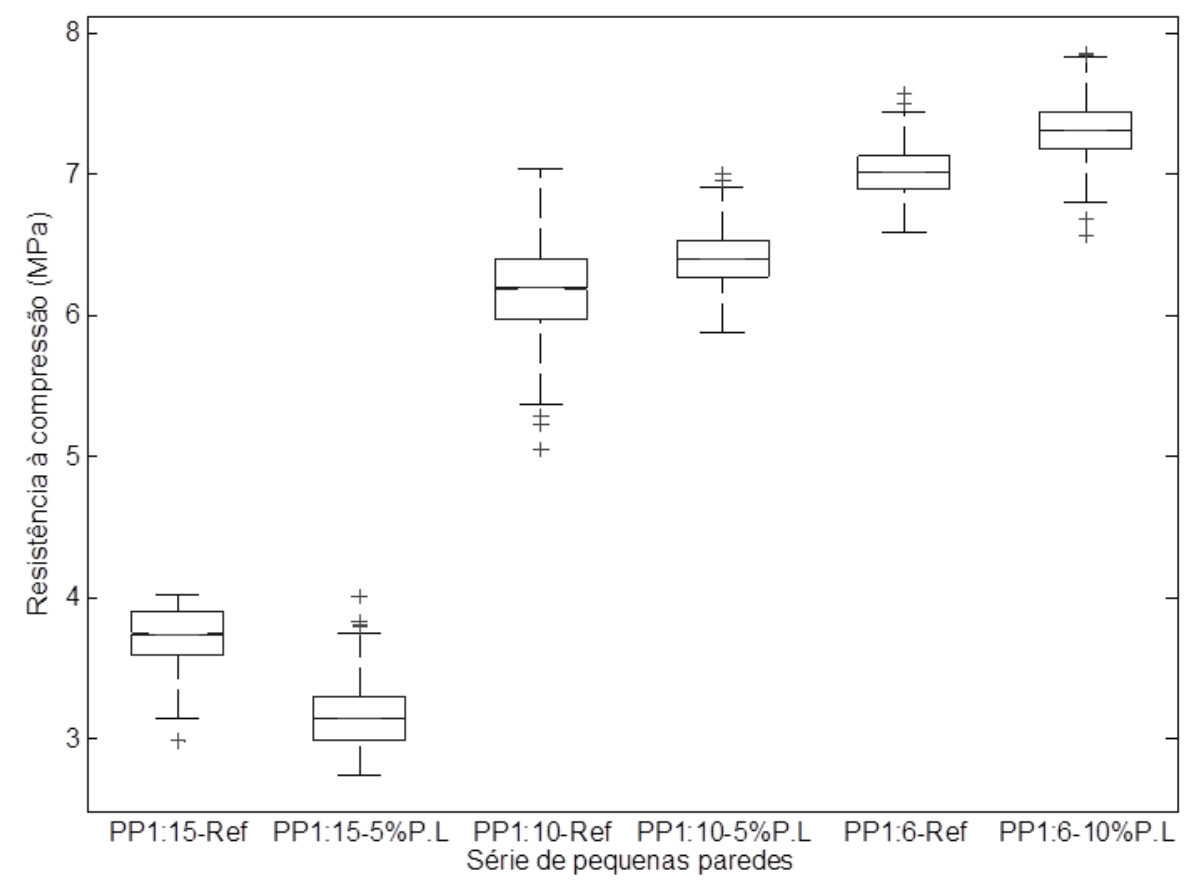

Figura 6.14 - Diagrama de caixa para os dados da resistência à compressão das paredes com os pós residuais (Fonte: autor)

Por meio do diagrama pode-se comprovar de forma visual o comportamento mecânico das pequenas paredes corroborando a análise anterior. Os dados apresentam uma distribuição simétrica pela posição equidistante da mediana dentro das caixas. Por outro lado, a caixa da série PP1:10-Ref apresentou maior altura, por conseguinte, teve valores mais dispersos e menos homogêneos com relação ao resto das paredes. É por essa razão que o intervalo de confiança do desvio padrão para esses elementos foi maior com relação ao resto das paredes.

A probabilidade de que as hipóteses nulas sejam aceitas para as paredes com os pós residuais é dada na Tabela 6.24 . 
Tabela 6.24 - Probabilidade de que as hipóteses nulas sejam aceitas para as paredes com os pós residuais (Fonte: autor)

\begin{tabular}{|c|c|c|c|c|c|c|}
\hline \multirow{2}{*}{ Traço 1:15 } & \multicolumn{3}{|c|}{ PP1:15-Ref } & \multicolumn{3}{|c|}{ PP1:15-5\%P.L } \\
\hline & $\mathrm{H}_{01}$ & $\mathrm{H}_{02}$ & $\mathrm{H}_{03}$ & $\mathrm{H}_{01}$ & $\mathrm{H}_{02}$ & $\mathrm{H}_{03}$ \\
\hline PP1:15-Ref & 0 & 100 & 0 & 0,19 & 33,04 & 66,77 \\
\hline PP1:1 & 66,77 & 33,04 & 0,19 & 0 & 100 & 0 \\
\hline \multirow{2}{*}{ Traço 1:10 } & \multicolumn{3}{|c|}{ PP1:10-Ref } & \multicolumn{3}{|c|}{ PP1:10-5\%P.L } \\
\hline & $\mathrm{H}_{01}$ & $\mathbf{H}_{02}$ & $\mathbf{H}_{03}$ & $\mathbf{H}_{01}$ & $\mathrm{H}_{02}$ & $\mathbf{H}_{03}$ \\
\hline PP1:10-Ref & 0 & 100 & 0 & 3,48 & 94,18 & 2,34 \\
\hline PP1:10 & 2,34 & 94,18 & 3,48 & 0 & 100 & 0 \\
\hline \multirow{2}{*}{ Traço 1:6 } & \multicolumn{3}{|c|}{ PP1:6-Ref } & \multicolumn{3}{|c|}{ PP1:6-10\%P.L } \\
\hline & $\mathrm{H}_{01}$ & $\mathrm{H}_{02}$ & $\mathrm{H}_{03}$ & $\mathbf{H}_{01}$ & $\mathrm{H}_{02}$ & $\mathrm{H}_{03}$ \\
\hline 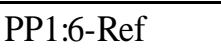 & 0 & 100 & 0 & 11,02 & 88,74 & 0,24 \\
\hline PP1:6-10\%P.L & 0,24 & 88,74 & 11,02 & 0 & 100 & 0 \\
\hline
\end{tabular}

Para o traço 1:15 existe $66,77 \%$ de probabilidade que a resistência média da parede com $5 \%$ de pó de resíduo orgânico seja inferior ao elemento de referência e 33,04\% que sejam iguais. Já para o traço 1:10, as pequenas paredes com adição do resíduo apresentaram 94,18\% de probabilidade que a resistência seja igual à parede controle e 2,34\% que seja superior. Com relação ao traço 1:6, o elemento com $10 \%$ de resíduo teve $11,02 \%$ de probabilidade de apresentar maior resistência comparada ao elemento de referência e 88,74\% de serem iguais. Sendo assim, é possível confirmar estatisticamente que as paredes com adição de pó de resíduo orgânico tiveram menor desempenho no traço 1:15 e igual desempenho às paredes de referência nos traços 1:10 e 1:6.

\subsubsection{Pequenas paredes com adição de fibra de sisal}

Na Tabela 6.25 são apresentados os intervalos de confiança da média, desvio padrão e coeficiente de variação da resistência à compressão, assim como os intervalos do fator eficiência parede/bloco $\left(f_{p p} / f_{b m}\right)$ e do fator eficiência parede/prisma $\left(f_{p p} / f_{p}\right)$ para uma confiabilidade de $95 \%$.

Tabela 6.25 - Resistência à compressão das pequenas paredes com adição de fibra de sisal (Fonte: autor)

\begin{tabular}{|c|c|c|c|c|c|c|c|c|c|c|}
\hline \multirow{3}{*}{$\begin{array}{l}\text { Tipo de Peq. } \\
\text { Parede }\end{array}$} & \multicolumn{6}{|c|}{ Resistência à compressão (MPa) } & \multirow{2}{*}{\multicolumn{2}{|c|}{$\begin{array}{c}\text { Fator de } \\
\text { Eficiência (fpp/fbm) }\end{array}$}} & \multirow{2}{*}{\multicolumn{2}{|c|}{$\begin{array}{c}\text { Fator de } \\
\text { Eficiência }(\mathbf{f} p p / f) \text { p }\end{array}$}} \\
\hline & \multirow{2}{*}{\multicolumn{2}{|c|}{$\frac{\text { Média }\left(\mathbf{f}_{\mathrm{pp}}\right)}{\text { Inferior Superior }}$}} & \multirow{2}{*}{\multicolumn{2}{|c|}{$\frac{\text { Sd }}{\text { Inferior Superior }}$}} & \multirow{2}{*}{\multicolumn{2}{|c|}{$\frac{\mathrm{CV}(\%)}{\text { Inferior Superior }}$}} & & & & \\
\hline & & & & & & & Mínimo & Máximo & Mínimo & Máximo \\
\hline & 5,47 & 6,71 & 0, & 1 , & 7, & 1 & 0,44 & 0 & 0,58 & 0,77 \\
\hline & 4,49 & 5,53 & 0,53 & 1,15 & 11,80 & 20, & 0,53 & 0,7 & 0,69 & 0,96 \\
\hline PP1:10-F2 & 5,14 & 6,29 & 0,58 & 1,21 & 11,28 & 19,24 & 0,52 & 0,71 & 0,69 & 0,90 \\
\hline
\end{tabular}


Nota-se que como as paredes reforçadas com as fibras apresentaram menor resistência em relação às paredes de referência, e os elementos PP1:10-F2 apresentaram maior resistência à compressão quando comparadas com as paredes PP1:10-F1. Os intervalos do fator de eficiência parede/bloco variaram entre 0,44 (valor mínimo) e 0,72 (valor máximo), e os intervalos do fator de eficiência parede/prisma variaram entre 0,58 (valor mínimo) e 0,96 (valor máximo) de forma geral para todos os elementos, sendo esses resultados consequentes com os fatores de eficiência encontrados na literatura.

Na Figura 6.15 é mostrado o diagrama de caixa dos valores médios da resistência de cada um das paredes para uma melhor compreensão dos resultados.

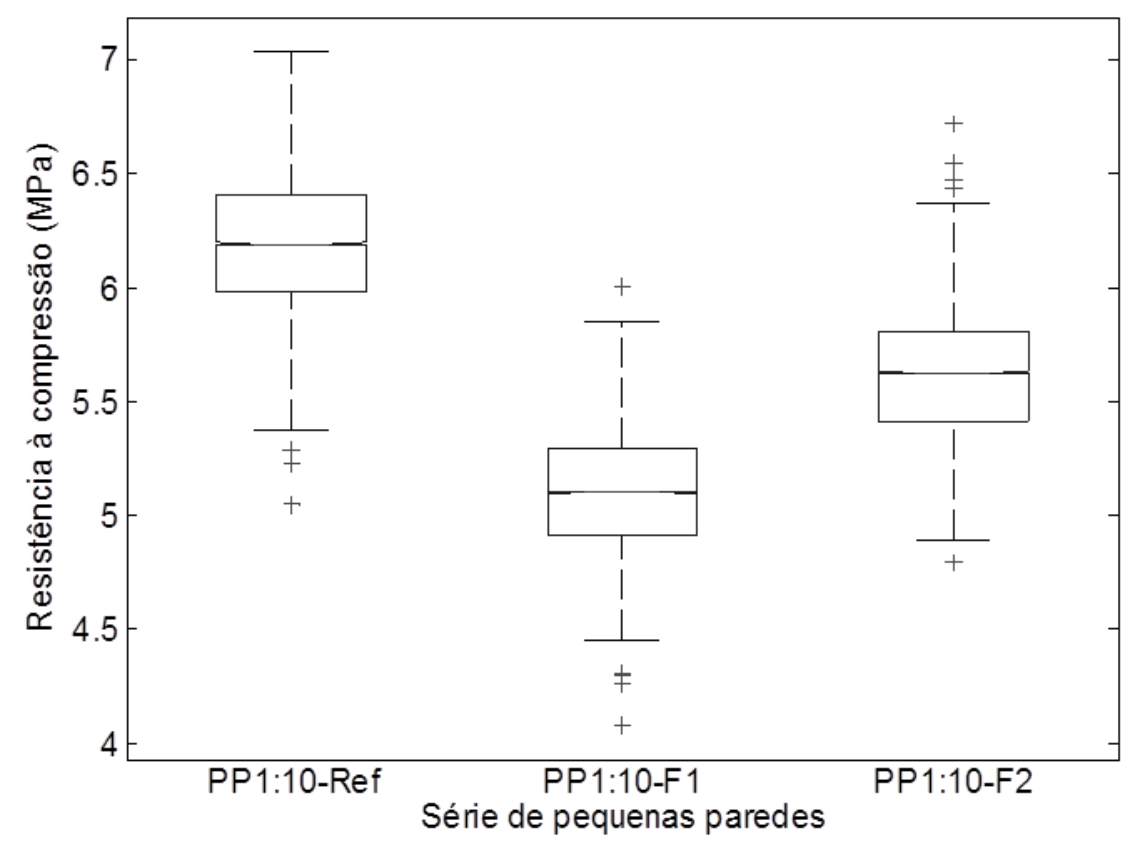

Figura 6.15 - Diagrama de caixa para os dados da resistência à compressão das paredes com fibra de sisal (Fonte: autor)

Por meio do diagrama pode-se comprovar de forma visual o comportamento mecânico das pequenas paredes corroborando a análise feita para a Tabela 6.25. De forma geral, os dados dos três grupos apresentaram uma distribuição simétrica. Por outo lado, tiveram maior variabilidade e dispersão dos mesmos. Isso pode ser comprovado nos intervalos de confiança do desvio padrão que foram maiores com relação às paredes com os pós residuais.

A probabilidade de que as hipóteses nulas sejam aceitas para as pequenas paredes com e sem adição de fibra de sisal é expressa na Tabela 6.26. 
Tabela 6.26 - Probabilidade de que as hipóteses nulas sejam aceitas para as paredes com fibra de sisal (Fonte: autor)

\begin{tabular}{|c|c|c|c|c|c|c|c|c|c|}
\hline \multirow{2}{*}{$\begin{array}{c}\text { Tipo de } \\
\text { Peq. Parede }\end{array}$} & \multicolumn{3}{|c|}{ PP1:10-Ref } & \multicolumn{3}{|c|}{ PP1:10-F1 } & \multicolumn{3}{|c|}{ PP1:10-F2 } \\
\hline & $\mathrm{H}_{01}$ & $\mathrm{H}_{02}$ & $\mathbf{H}_{03}$ & $\mathrm{H}_{01}$ & $\mathrm{H}_{02}$ & $\mathbf{H}_{03}$ & $\mathrm{H}_{01}$ & $\mathrm{H}_{02}$ & $\mathrm{H}_{03}$ \\
\hline DD1.10 Pef & 0 & 100 & 0 & 0,10 & 20,54 & 79,36 & 0,22 & 83,12 & 16,66 \\
\hline PP1:1 & 79,36 & 20,54 & 0,10 & 0 & 100 & 0 & 13,92 & 85,78 & 0,30 \\
\hline PP1:10-F2 & 16,66 & 83,12 & 0,22 & 0,30 & 85,78 & 13,92 & 0 & 100 & 0 \\
\hline
\end{tabular}

Analisando-se os resultados da Tabela 6.26, nota-se que a parede de referência, para um nível de significância de 5\%, teve $79,36 \%$ de probabilidade de que a sua resistência seja superior à resistência do elemento PP1:10-F1 e 20,54\% que sejam iguais. Além disso, quando a parede controle é analisada conjuntamente com a parede PP1:10-F2, evidencia-se estatisticamente que há $16,66 \%$ de probabilidade que a resistência do elemento sem adição de fibra seja superior ao elemento reforçado e $83,12 \%$ de serem iguais.

Fazendo-se uma análise entre as paredes, prismas e blocos reforçados com a fibra, podese concluir que as paredes, já seja o sisal imerso na matriz comum ou modificada, tiveram melhor desempenho com relação aos prismas e blocos porque apresentaram maior porcentagem de valores iguais aos exemplares sem adição de fibra. A pequena parede constitui o corpo de prova que melhor representa o modo de ruptura da alvenaria estrutural, por se tratar de um elemento composto por um conjunto de blocos unidos por argamassas através de juntas horizontais alinhadas e verticais defasadas do meio bloco. Dessa forma, as fibras de sisal tiveram melhor desempenho porque provavelmente foram desenvolvidas maiores tensões de tração nas unidades. Essa situação se explica por dois motivos principais. O primeiro é que o corpo de prova apresenta maiores dimensões, sendo submetido a um menor confinamento produzido pelo aparato de ensaio. Além disso, maiores trações nos blocos também podem ser explicadas pelo fato de existirem juntas verticais defasadas, o que não ocorre nos prismas. Sob esse tipo de solicitação, as fibras atuam como reforço eficiente e podem efetivamente contribuir para melhorar a capacidade resistente do material.

Com relação aos elementos reforçados com fibras, a parede PP1:10-F1 apresentou $13,92 \%$ de probabilidade das resistências serem menores que a parede PP1:10-F2 e 85,78\% de probabilidade das resistências serem iguais. Pode-se disser que estatisticamente apresentaram um desempenho mecânico similar.

\subsection{Modos de ruptura das pequenas paredes}

A Figura 6.16 apresenta a forma de ruptura das pequenas paredes de referência e com adição do pó residual orgânico. 

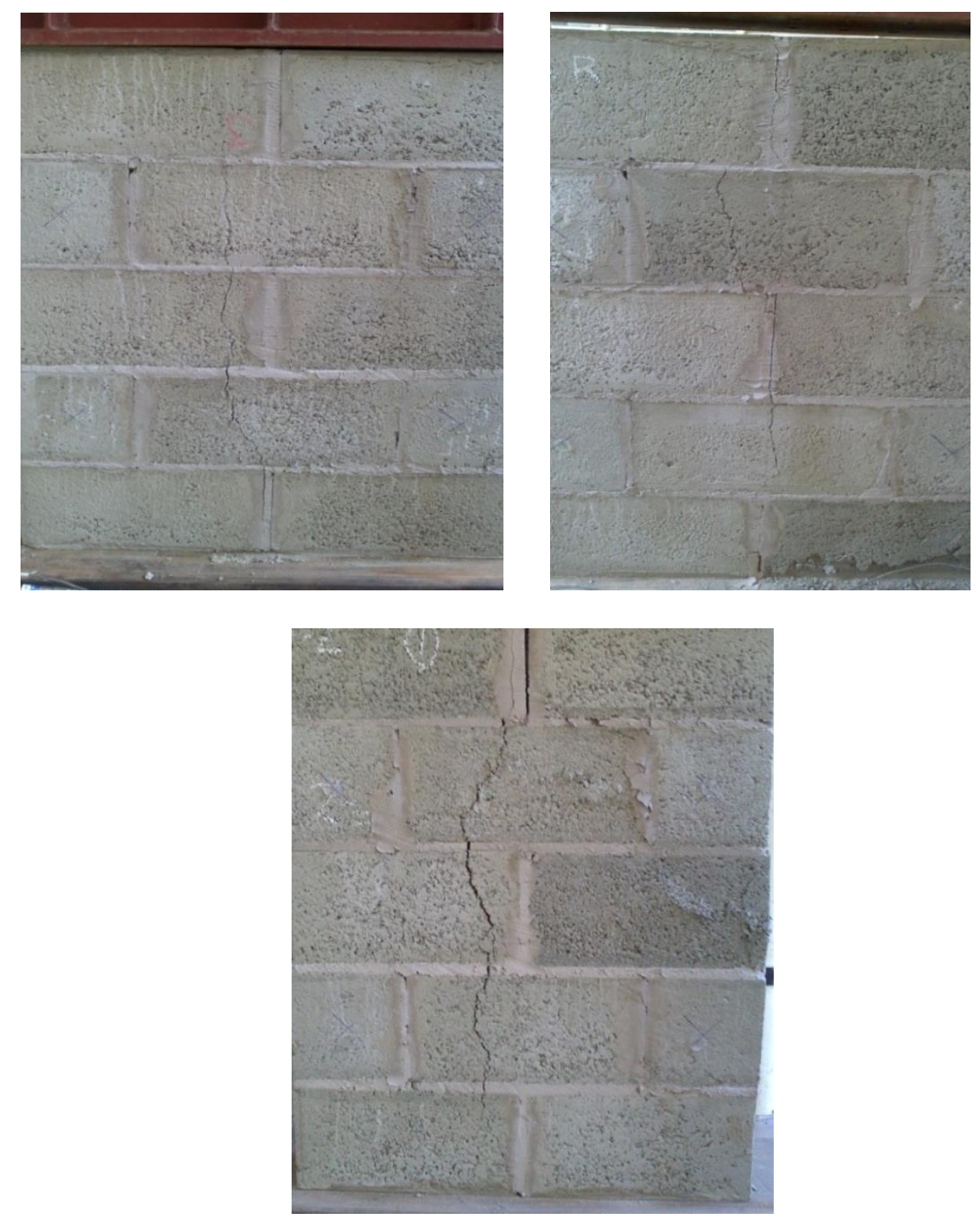

Figura 6.16 - Propagação de fissuras verticais de tração (Fonte: autor)

Fissuras verticais de tração foram observadas nas faces laterais principais das pequenas paredes. Elas começaram nas juntas verticais, progrediram pelos blocos adjacentes e provocaram a sua ruptura. De forma geral, surgiram também, fissuras verticais ao longo faces laterais menores, ocorrendo ruptura por tração transversal nos blocos (Figura 6.17). 

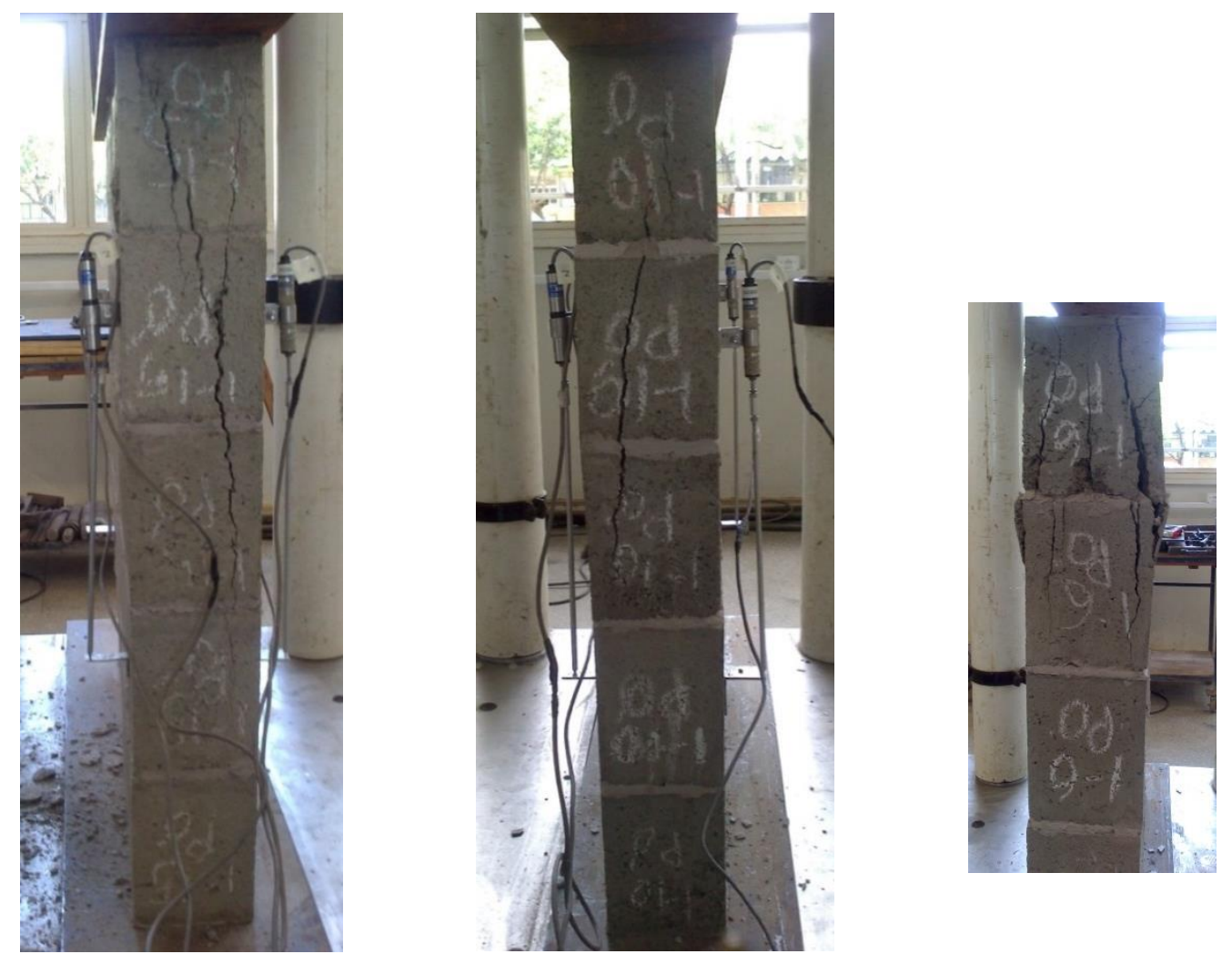

Figura 6.17 - Fissuras verticais ao longo dos septos laterais (Fonte: autor)

Foi observado durante o ensaio de compressão que nas paredes pertencentes aos traços 1:15 e 1:10 ocorreu um rompimento com rápida propagação de fissuras. Já nos elementos mais resistentes correspondentes ao traço 1:6 ocorreu um colapso explosivo. No entanto, as paredes com adição de fibra de sisal mostraram uma ruptura menos frágil, como se apresenta na Figura 6.18.

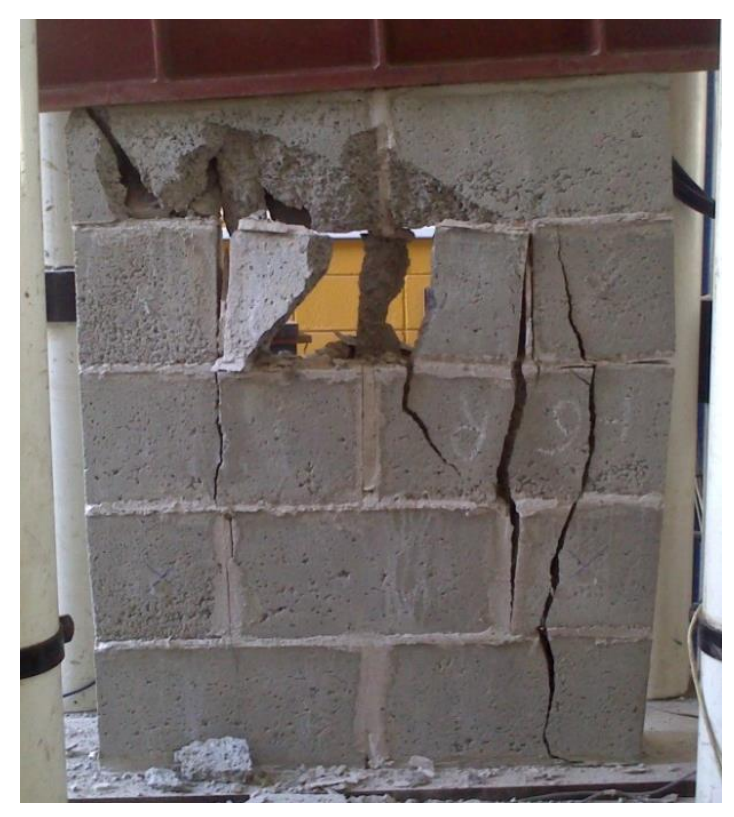

(a)

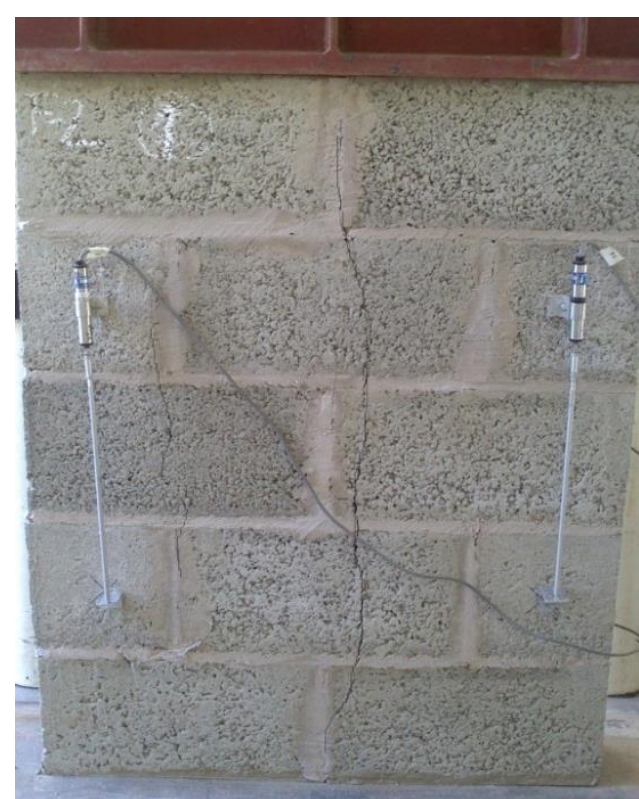

(b)

Figura 6.18 - Ruptura das paredes sob compressão: (a) ruptura frágil das paredes sem adição de fibras, (b) ruptura das paredes com adição de fibras (Fonte: autor) 
A aderência fibra-matriz é o principal fator de influência sobre a tenacidade e permite que as partes do elemento que se encontram fissuradas mantenham-se unidas provocando uma ruptura com característica mais dúctil.

\subsection{Módulo de deformação das pequenas paredes}

\subsubsection{Pequenas paredes produzidas com os pós residuais}

Os resultados dos intervalos de confiança do módulo de deformação, desvio padrão e coeficiente de variação das pequenas paredes com os pós residuais referidos à área bruta são apresentados na Tabela 6.27. Também pode-se observar os intervalos da relação entre o módulo de deformação e a resistência média à compressão das paredes $\left(\mathrm{E}_{\mathrm{pp}} / \mathrm{f}_{\mathrm{pp}}\right)$ contendo os valores extremos da faixa para uma confiabilidade de $95 \%$.

Tabela 6.27 - Módulo de deformação das paredes com os pós residuais (Fonte: autor)

\begin{tabular}{|c|c|c|c|c|c|c|c|c|}
\hline \multirow{3}{*}{$\begin{array}{l}\text { Tipo de Peq. } \\
\text { Parede }\end{array}$} & \multicolumn{6}{|c|}{ Módulo de deformação (MPa) } & \multirow{2}{*}{\multicolumn{2}{|c|}{ Relação Epp/fpp }} \\
\hline & \multirow{2}{*}{\multicolumn{2}{|c|}{$\frac{\text { Média }\left(\mathbf{E}_{\mathbf{p}}\right)}{\text { Inferior Superior }}$}} & \multirow{2}{*}{\multicolumn{2}{|c|}{$\frac{\text { Sd }}{\text { Inferior Superior }}$}} & \multirow{2}{*}{\multicolumn{2}{|c|}{$\frac{\mathrm{CV}(\%)}{\text { Inferior Superior }}$}} & & \\
\hline & & & & & & & Mínima & Máxima \\
\hline PP1:15-Ref & 5072 & 6013 & 423 & 915 & 8 & 15 & 1283 & 1892 \\
\hline PP1:15-5\%P & 4218 & 5507 & & 947 & 1 & 17 & 1176 & 1913 \\
\hline PP1:10-Ref & 8326 & 9627 & 509 & 1252 & 6 & 13 & 1241 & 1761 \\
\hline PP1:10-5\%P.L & 8645 & 10971 & 895 & 1719 & 10 & 16 & 1274 & 1812 \\
\hline PP1:6-Ref & 9609 & 10886 & 861 & 1618 & 9 & 15 & 1340 & 1646 \\
\hline PP1:6-10\%P.L & 11341 & 12433 & 921 & 1442 & 8 & 12 & 1526 & 1854 \\
\hline
\end{tabular}

De forma similar ao que ocorreu nos prismas, houve redução da rigidez das paredes com adição de 5\% de pó de resíduo orgânico comparados com os elementos de referência para o traço 1:15. Já as paredes construídos com os blocos que apresentaram na mistura proporções de pó de resíduo orgânico de 5 e 10\% para os traços 1:10 e 1:6, respectivamente, tiveram maior módulo de deformação mais elevado quando comparado aos elementos de referência.

Os intervalos da razão entre o módulo e a resistência média da parede variaram na faixa de 1176 (valor mínimo) e 1913 (valor máximo). Juste (2001) obteve valores entre 1286 e 1559 em pequenas paredes $(0,80$ x 0,80m) usando argamassa média. Buttler (2007) obteve valores próximos a 1400 em paredes com resistência de 6,48 $\mathrm{MPa}$.

As curvas tensão $v s$ deformação das paredes foram traçadas (Figura 6.19). Cada ilustração contém as curvas das cinco paredes ensaiadas no laboratório e a curva superior e inferior do intervalo de confiança utilizando a técnica do Bootstrap. Desse modo pode-se dizer que existe $95 \%$ de probabilidade de que a curva tensão $v s$ deformação da população encontra-se dentro dessa banda. 

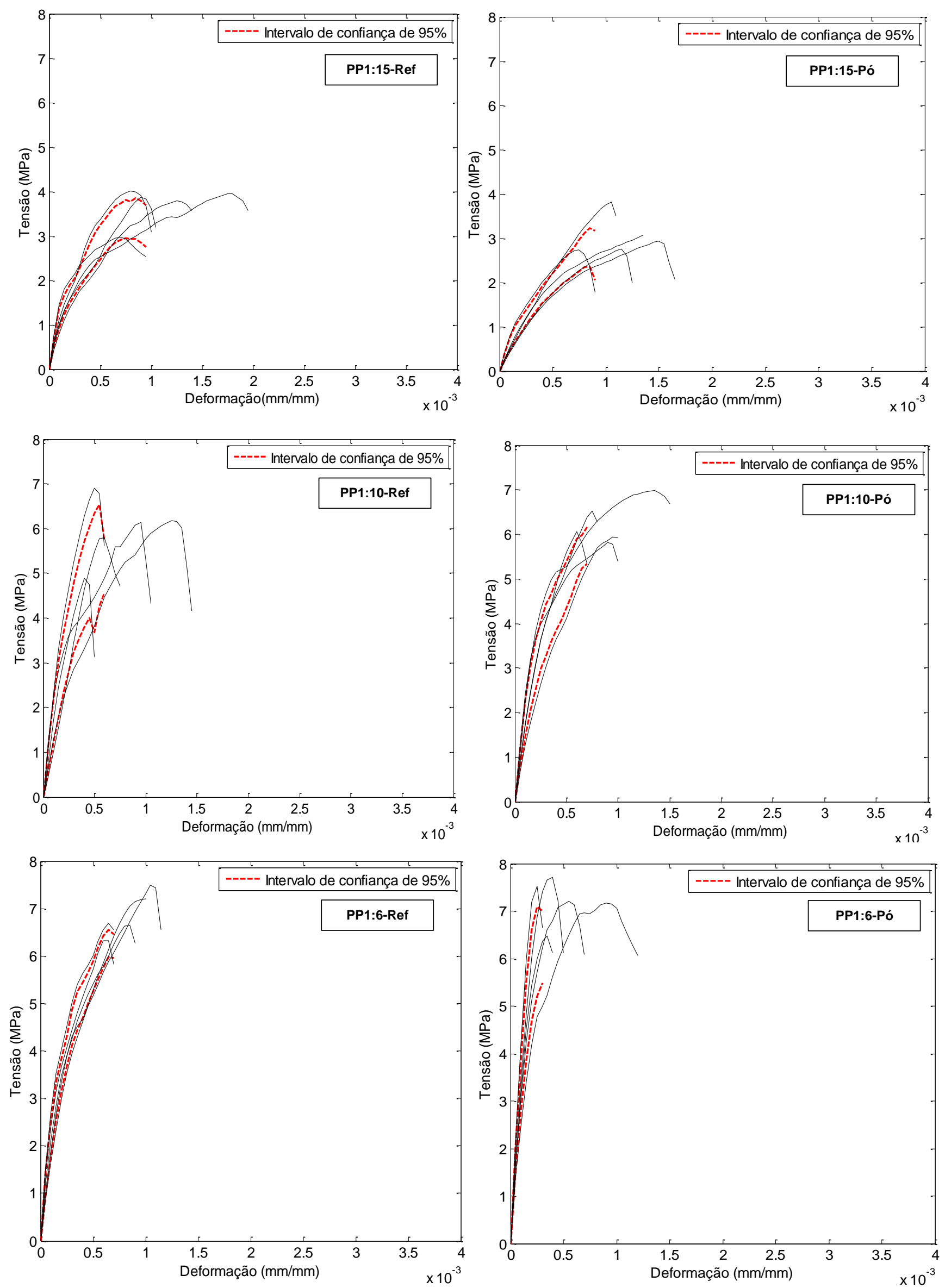

Figura 6.19 - Curvas tensão vs deformação das paredes com os pós residuais (Fonte: autor) 


\subsubsection{Pequenas paredes produzidas com adição de fibra de sisal}

Os resultados dos intervalos de confiança do módulo de deformação, desvio padrão e coeficiente de variação das pequenas paredes com adição de fibra de sisal referidos à área bruta são apresentados na Tabela 6.28. Também pode-se observar os intervalos da relação entre o módulo de deformação e a resistência média à compressão das paredes $\left(\mathrm{E}_{\mathrm{pp}} / \mathrm{f}_{\mathrm{pp}}\right)$ contendo os valores extremos da faixa para uma confiabilidade de $95 \%$.

Tabela 6.28 - Módulo de deformação das paredes com adição de fibra de sisal (Fonte: autor)

\begin{tabular}{|c|c|c|c|c|c|c|c|c|}
\hline \multirow{3}{*}{$\begin{array}{l}\text { Tipo de Peq. } \\
\text { Parede }\end{array}$} & \multicolumn{6}{|c|}{ Módulo de deformação (MPa) } & \multirow{2}{*}{\multicolumn{2}{|c|}{ Relação Epp/fpp }} \\
\hline & \multicolumn{2}{|c|}{ Média $\left(\mathbf{E}_{\mathbf{p}}\right)$} & \multicolumn{2}{|c|}{ Sd } & \multicolumn{2}{|c|}{$\mathrm{CV}(\%)$} & & \\
\hline & Inferior & Superior & Inferior & Superior & Inferior & Superior & Mínima & Máxima \\
\hline PP1:10-Ref & 8326 & 9627 & 509 & 1252 & 6 & 13 & 1241 & 1761 \\
\hline PP1:10-F1 & 6691 & 7496 & 456 & 1079 & 7 & 14 & 1210 & 1669 \\
\hline PP1:10-F2 & 7742 & 8714 & 604 & 1346 & 8 & 15 & 1231 & 1695 \\
\hline
\end{tabular}

As paredes reforçadas com fibras tiveram menor módulo de deformação com relação aos elementos de referência devido a um concreto menos denso e resistente. Por outro lado, as paredes PP1:10-F2 apresentaram maior módulo de deformação em referência às paredes PR1:10-F1 por causa da matriz modificada apresentar melhoria na zona de interface fibras/pasta de cimento. A relação módulo/resistência variou na faixa de 1210 (valor mínimo) e 1669 (valor máximo), sendo esses valores coerentes aos encontrados na literatura.

$\mathrm{Na}$ Figura 6.20 mostram-se as curvas tensão $v s$ deformação das pequenas paredes reforçadas com o sisal e das paredes de referência. Cada ilustração contém as curvas das cinco paredes ensaiadas no laboratório e a curva superior e inferior do intervalo de confiança usando a técnica do Bootstrap. Dessa forma, é possível inferir que a média populacional da tensão de cada elemento estudado encontra-se nessa banda de confiança para uma deformação específica com $95 \%$ de probabilidade. 

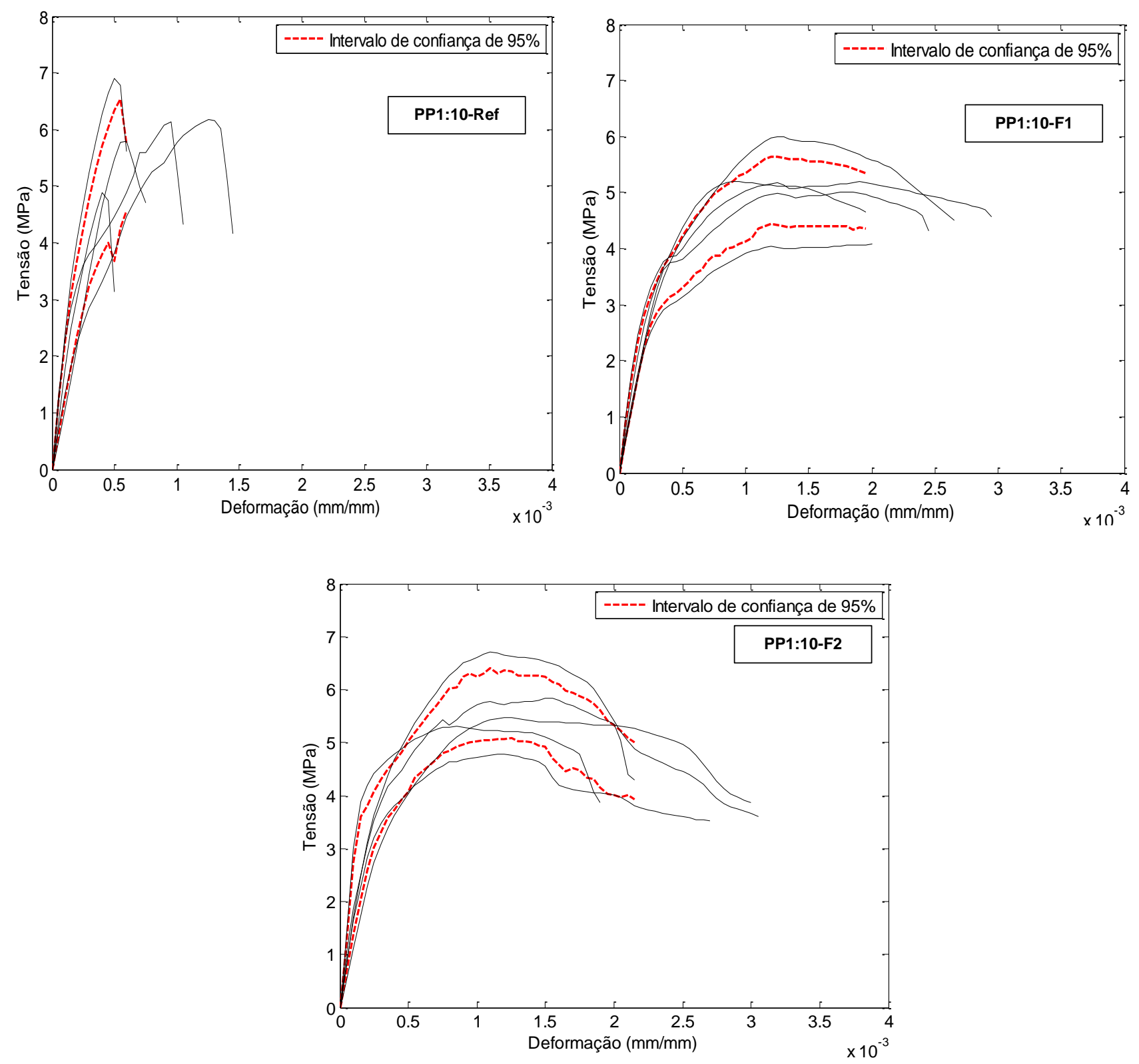

Figura 6.20 - Curvas tensão vs deformação das paredes com adição de fibra de sisal (Fonte: autor)

Também, de forma semelhante ao observado para os prismas, percebe-se que nas paredes reforçadas com a fibra vegetal há um ganho na capacidade de absorber deformações após terem alcançado a carga última, embora haja redução da resistência final à compressão. É importante lembrar que fibras de baixo módulo de deformação destinam-se predominantemente a melhorar o desempenho dos compósitos no estado pós-fissurado. A aderência fibra-matriz é o principal fator de influência sobre a tenacidade que é a quantidade de energia que é absorvida por um material durante o processo de fraturamento. Um parâmetro indicativo da tenacidade é a área total sob a curva tensão vs deformação. Segundo Mehta e Monteiro (2008) o compósito reforçado suportará cargas cada vez maiores após a 
primeira fissura da matriz devido à resistência das fibras ao arrancamento. Com uma carga cada vez maior, as fibras tendem a transferir a tensão adicional para a matriz através de tensões de aderência até que haja rompimento das fibras ou até que o escorregamento local acumulado leve ao arrancamento das fibras.

\subsection{A valiação da durabilidade da fibra de sisal no concreto}

Como já exposto na metodologia, a durabilidade da fibra de sisal foi avaliada por meio de ensaios de resistência à tração indireta dos blocos e por observações da matriz em um microscópico eletrônico de varredura.

\subsubsection{Resistência à tração indireta dos blocos}

Os intervalos de confiança da média, desvio padrão e coeficiente de variação da resistência à tração indireta dos blocos $\left(\mathrm{f}_{\mathrm{tb}, \text { ind }}\right)$ com e sem adição de sisal, referidos à área líquida, podem ser observado na Tabela 6.29. Também foram encontradas a relação máxima e mínima entre a resistência à tração e a resistência à compressão das unidades $\left(\mathrm{f}_{\mathrm{tb}, \mathrm{inf}} / \mathrm{f}_{\mathrm{cb}}\right)$, ambas na área líquida, para uma confiabilidade de $95 \%$.

Tabela 6.29 - Resistência à tração indireta dos blocos reforçados com a fibra de sisal (Fonte: autor)

\begin{tabular}{|c|c|c|c|c|c|c|c|c|}
\hline \multirow{3}{*}{$\begin{array}{l}\text { Tipo de } \\
\text { Bloco }\end{array}$} & \multicolumn{6}{|c|}{ Resistência à tração indireta (MPa) } & \multirow{2}{*}{\multicolumn{2}{|c|}{$\begin{array}{c}\text { Resist. à tração/ } \\
\text { Resist. à compressão } \\
(\%)\end{array}$}} \\
\hline & \multicolumn{2}{|c|}{ Média (ftb, ind) } & \multicolumn{2}{|c|}{ Sd } & \multicolumn{2}{|c|}{ CV (\%) } & & \\
\hline & Inferiol & Superior & Inferio & Superior & Inferio & Superior & $\begin{array}{l}\text { ftb,inf/fcb } \\
\text { mínima }\end{array}$ & $\begin{array}{l}\text { ftb,inf/fcb } \\
\text { máxima }\end{array}$ \\
\hline BE1:10-Ref & 0,95 & 1,16 & 0,10 & 0,20 & 10,53 & 17,24 & 4,31 & 6,02 \\
\hline BE1:10-F1 & 1,00 & 1,39 & 0,17 & 0,35 & 17,00 & 25,18 & 6,65 & 10,16 \\
\hline BE1:10-F2 & 1,62 & 1,96 & 0,21 & 0,42 & 12,96 & 21,43 & 9,27 & 12,05 \\
\hline
\end{tabular}

As unidades reforçadas com o sisal apresentaram maior resistência à tração indireta com relação ao bloco controle. A adição de fibras melhora consideravelmente as propriedades de tração dos compósitos, produto do trabalho conjunto da interface fibra-matriz.

Com relação aos intervalos da razão resistência à tração/resistência à compressão $\left(\mathrm{f}_{\mathrm{tb}, \text { inf }} / \mathrm{f}_{\mathrm{cb}}\right)$, autores como Barbosa (2004) concluíram que a tração do bloco de concreto resulta em uma resistência entre $8 \%$ a $16 \%$ da sua resistência à compressão. O bloco de referência apresentou valores inferiores aos citados pela literatura. Por outro lado, os blocos com adição de sisal mostraram uma relação superior devido à adição da fibra vegetal. De fato, a unidade 
BE1:10-F2 apresentou a maior relação, produto do melhor desempenho e da maior durabilidade da fibra na matriz modificada com sílica e cimento de alto forno.

No ensaio de tração indireta do bloco foi posicionado um transdutor de deslocamentos na região onde estava prevista a formação da fissura para obter a energia de fratura na tração. A energia de fratura, denotada por $\mathrm{G}_{\mathrm{f}}$, representa a energia necessária para que seja criada uma fissura completa de área unitária e é dada pela área sob a curva tração indireta $v s$ abertura da fissura. A Figura 6.21 ilustra as curvas dos seis blocos ensaiados para cada série e também a faixa de confiança representada por uma curva superior e outra inferior aplicando a técnica do Bootstrap para uma confiabilidade de $95 \%$.
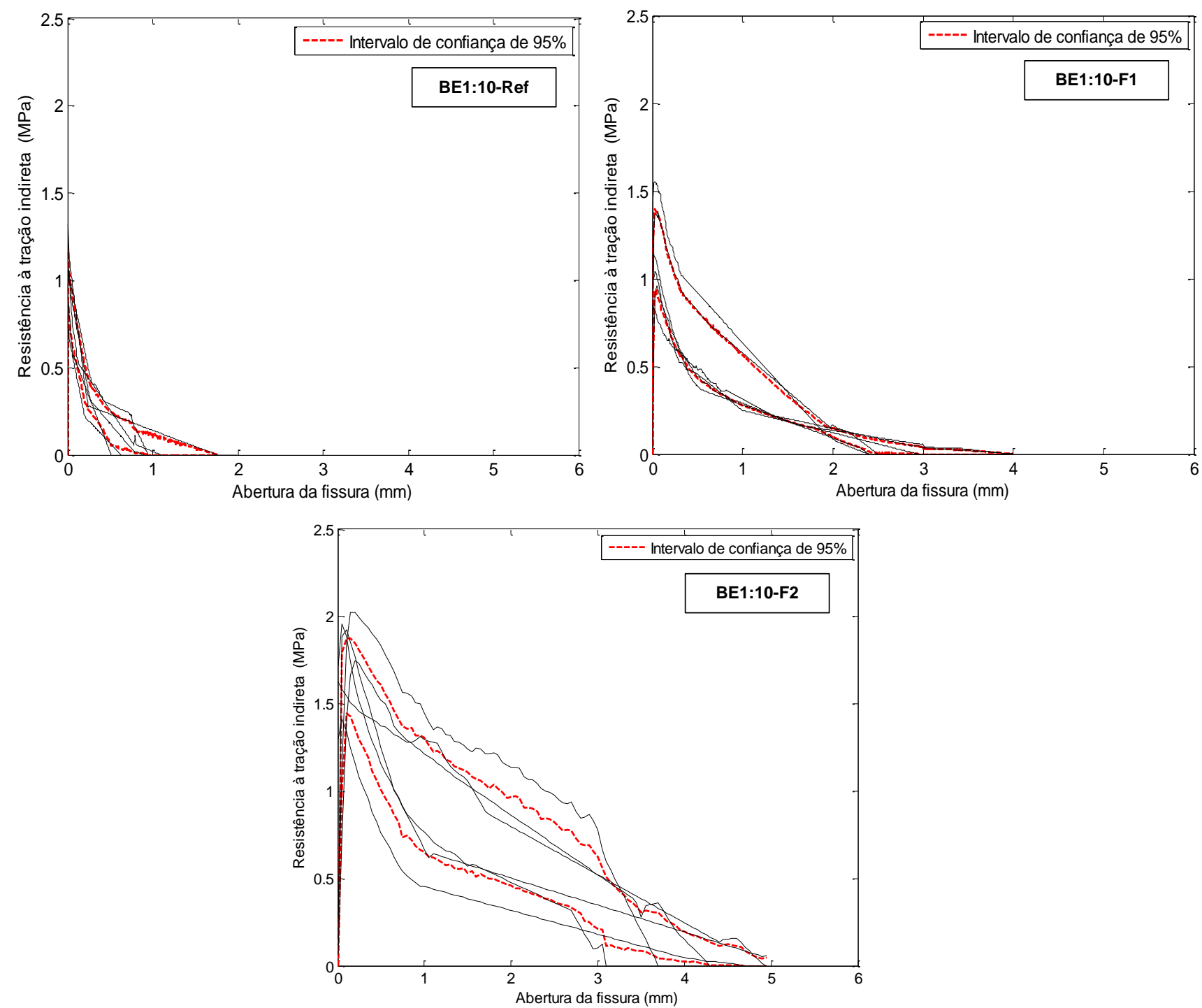

Figura 6.21 - Curvas tração indireta vs abertura da fissura (Fonte: autor)

Segundo Hanai, Takeuti e Carrazedo (2004), o concreto, com exceção daqueles de resistência muito elevada, tem as características de um material quase-frágil. Esse tipo de comportamento foi observado na Figura 6.21 nos blocos sem fibras devido a que tensão é 
reduzida a zero quase instantaneamente. Pode-se notar como as curvas apresentaram uma inclinação descendente mais pronunciada com relação aos blocos com fibras. Já as unidades reforçadas com fibras apresentaram um comportamento dúctil, caracterizadas pelo decréscimo gradual da tensão após pico e uma abertura de fissura de forma progressiva. Na Figura 6.22 observa-se esse tipo de comportamento na ruptura dos blocos.

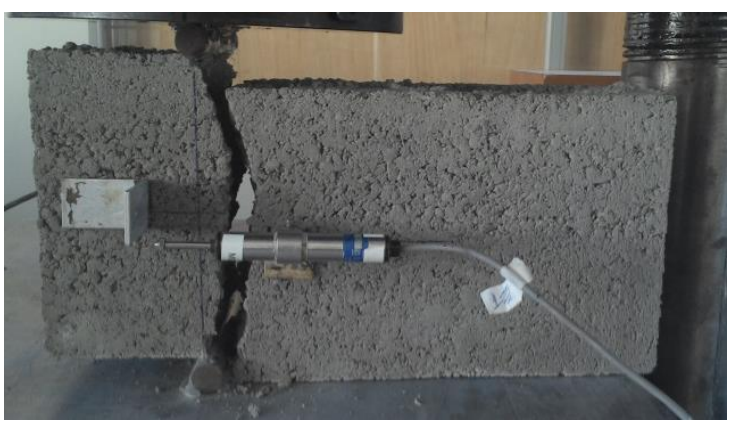

(a)

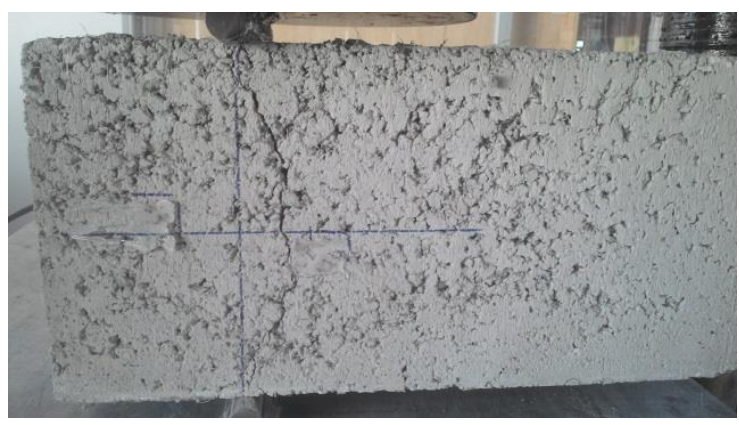

(b)

Figura 6.22 - Ruptura dos blocos no ensaio de resistência à tração indireta: (a) ruptura frágil dos blocos sem adição de fibras e (b) ruptura dúctil dos blocos com adição de fibras (Fonte: autor)

A área sob a curva observada na Figura 6.21 é maior para os blocos com sisal imersos na matriz modificada com a sílica e o cimento Portland de alto forno, portanto, tiveram maior energia de fratura. Isso mostra que a fibra não sofreu deterioração nem petrificação devido a uma matriz menos alcalina com menor teor de $\mathrm{CH}$. Portanto, as fibras apresentaram maior durabilidade com relação ao sisal imerso no bloco feito com o cimento Portland ARI. Os resultados da energia de fratura encontram-se na Tabela 6.30. O valor mínimo do intervalo é dado pela área sob a curva vermelha inferior e o valor máximo pela área sob a curva vermelha superior dos gráficos tração indireta vs abertura da fissura.

Tabela 6.30 - Energia de fratura dos blocos reforçados com a fibra de sisal (Fonte: autor)

\begin{tabular}{|c|c|c|c|c|c|c|}
\hline \multirow{2}{*}{$\begin{array}{l}\text { Tipo de } \\
\text { Bloco }\end{array}$} & \multicolumn{2}{|c|}{$\begin{array}{c}\text { Energia de fratura Gf } \\
\text { (MPa.mm) }\end{array}$} & \multicolumn{2}{|c|}{ Sd (MPa.mm) } & \multicolumn{2}{|c|}{ CV (\%) } \\
\hline & Inferior & Superior & Inferiol & Superior & Inferiol & Superior \\
\hline BE1:10-Ref & 0,95 & 1,16 & 0,08 & 0,15 & 8,42 & 12,93 \\
\hline BE1:10-F1 & 1,00 & 1,39 & 0,11 & 0,20 & 11,00 & 14,39 \\
\hline BE1:10-F2 & 1,62 & 1,96 & 0,19 & 0,38 & 11,73 & 19,39 \\
\hline
\end{tabular}

Os blocos com fibra apresentaram maior ductilidade e absorção de energia com relação aos blocos de referência. Isso demostra que o concreto reforçado com as fibras vegetais apresentou um bom desempenho na condição pós-fissurado, melhor controle da fissuração e maior capacidade de carregamento após o aparecimento das primeiras trincas. 
Os resultados da Tabela 6.30 mostram que a unidade BE1:10-F1 teve pior desempenho que o bloco BE1:10-F2, produto da degradação mecânica do sisal na matriz cimentícia. Entretanto, matrizes menos alcalinas e com adição de materiais pozolânicos podem aumentar a durabilidade da fibra e o resultado é um composto mais resistente aos esforços de tração com maior capacidade de absorção de energia.

\subsubsection{Análise da microestrutura do compósito}

Fibras de sisal isoladas e fragmentos de blocos com o sisal imerso no concreto foram analisados em microscópico eletrônico de varredura (MEV) e foi feita a espectroscopia de energia dispersiva por raio-X (EDS) para a obtenção qualitativa da composição química de uma região selecionada.

A Figura 6.23 mostra a seção longitudinal da fibra isolada em três situações: em estado natural (FR), extraída da matriz com cimento CP V-ARI (F1) e extraída da matriz modificada para aumentar a durabilidade das fibras (F2).

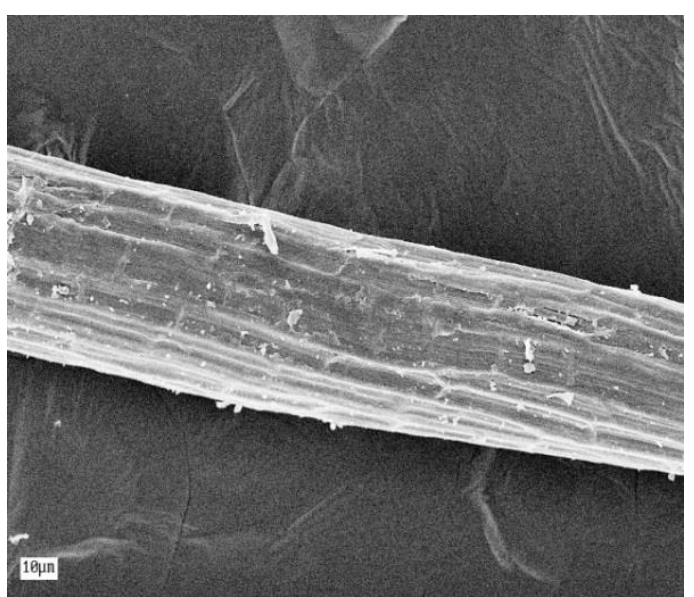

(a)

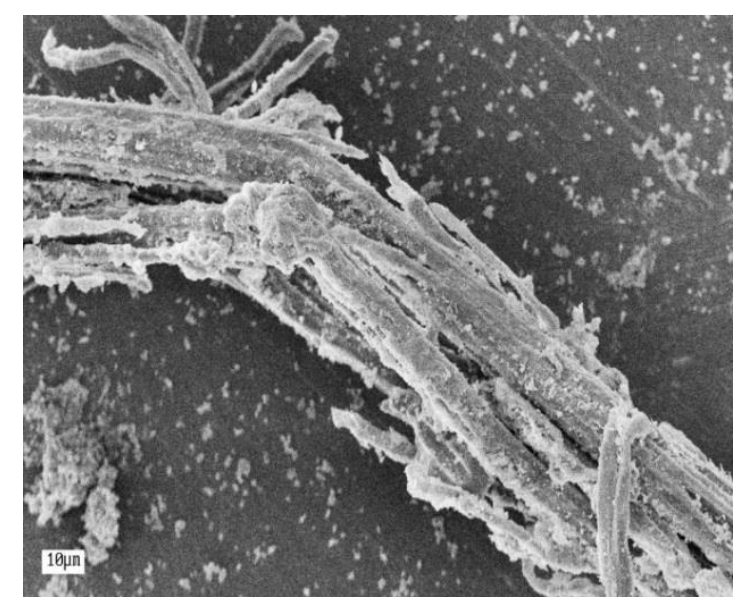

(b)

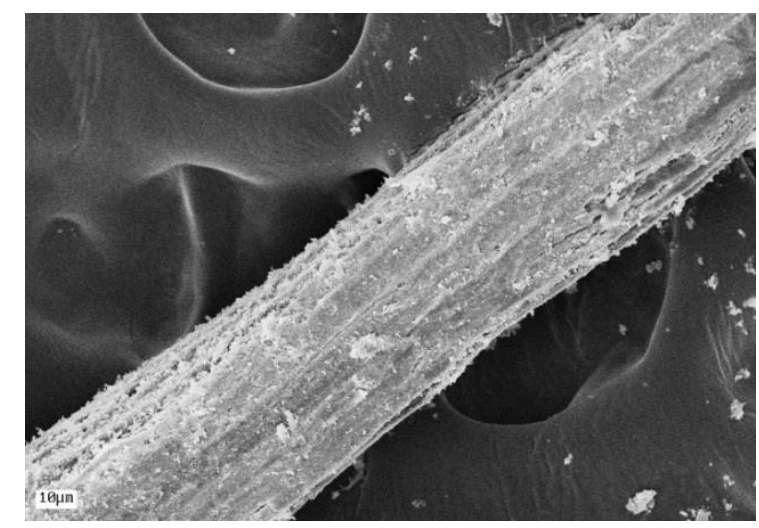

(c)

Figura 6.23 - Microimagens da seção longitudinal da fibra isolada: (a) em estado natural, (b) extraída da matriz com cimento Portland ARI e (c) extraída da matriz modificada (Fonte: autor) 
Comparando as fibras removidas do concreto com a fibra in natura pode-se observar que existe uma camada de produtos de hidratação do cimento em suas superfícies. Por outro lado, é notável a degradação da fibra (F1) que ficou imersa na matriz feita com o cimento de alto porcentual de clínquer, com relação à fibra extraída da matriz modificada pelos materiais pozolânicos (ś́lica e escória de alto forno). Portanto, o uso de cimentos com baixa alcalinidade confere melhoria do desempenho dos compósitos em longo prazo devido a uma maior conservação e integridade da fibra vegetal no concreto. O espectro de EDS foi realizado na superfície de cada uma das fibras de sisal (Figura 6.24).

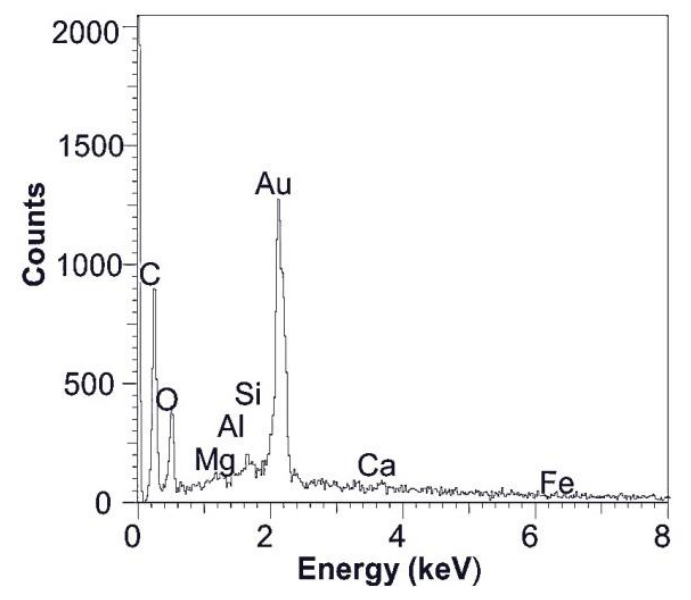

(a)

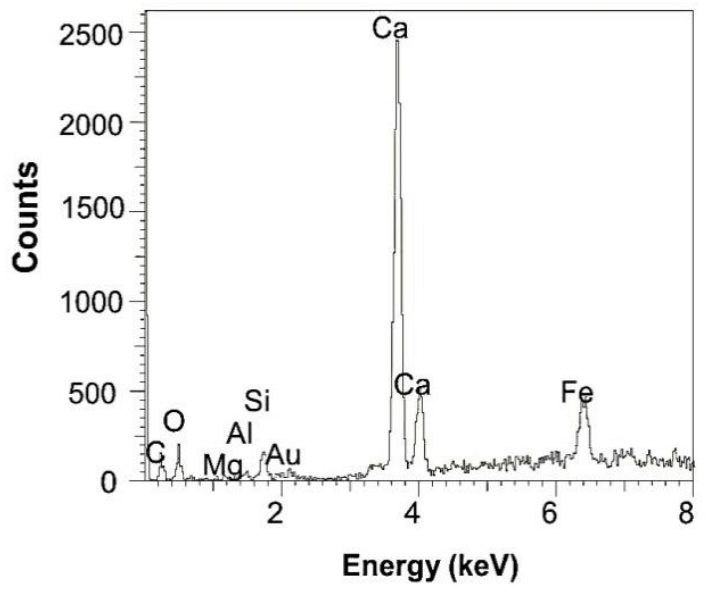

(b)

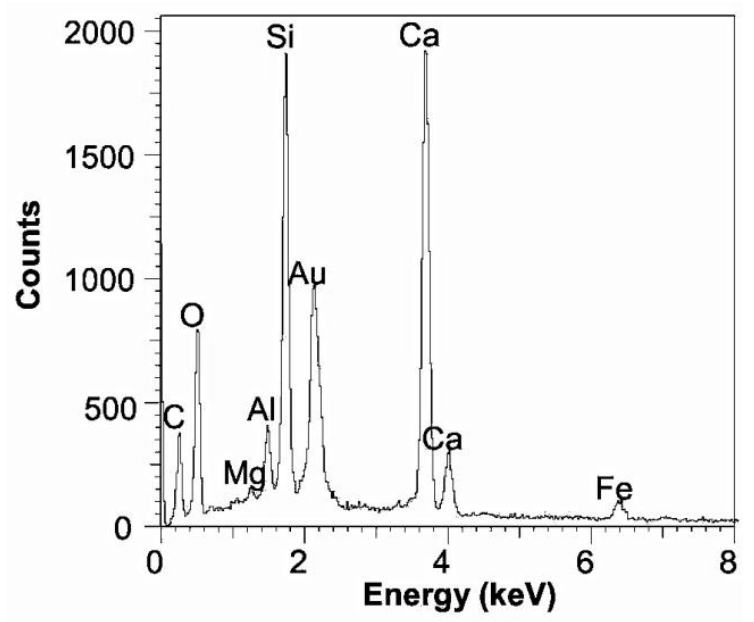

(c)

Figura 6.24 - Espectros obtidos por EDS da fibra de sisal (a) em estado natural, (b) extraída da matriz com cimento Portland ARI e (c) extraída da matriz modificada (Fonte: autor)

Segundo o espectro de EDS da Figura 6.24, a fibra de referência apresentou baixa proporção de cálcio, sílica, magnésio, alumínio e ferro como era esperado. Entretanto, o EDS das fibras que ficaram imersas no concreto mostraram a presênça dos elementos químicos fundamentais da hidratação do cimento. Embora nehuma medida quantitativa possa ser 
inferida dessas análises, pode-se notar maior quantidade Ca na superfície da fibra F1, entendendo que existe alta concentração de hidróxido de cálcio. Isso colabora com a suposição de ocorrência do fenômeno de mineralização, fragilização e petrificação da fibra resultante da migração do $\mathrm{CH}$ para a cavidade central, as paredes e os vazios onde o composto químico se cristaliza. Fibras frágeis sofrem ruptura sem alongamento considerável, não contribuindo para o incremento da ductilidade e tenacidade do compósito. Por outro lado, os picos registrados no espectro de EDS da fibra F2, correspondentes aos elementos químicos $\mathrm{Ca}$ e $\mathrm{Si}$, são de magnitudes similares. Isso indica a incidência de produtos de hidratação com baixas concentrações de portlandita $(\mathrm{CH})$, causando menor degradação do sisal no concreto (Savastano et al., 2009).

Fragmentos de concreto pertencente aos blocos reforçados também foram analizados para avaliar o estado das fibras imersas na matriz (Figura 6.25).

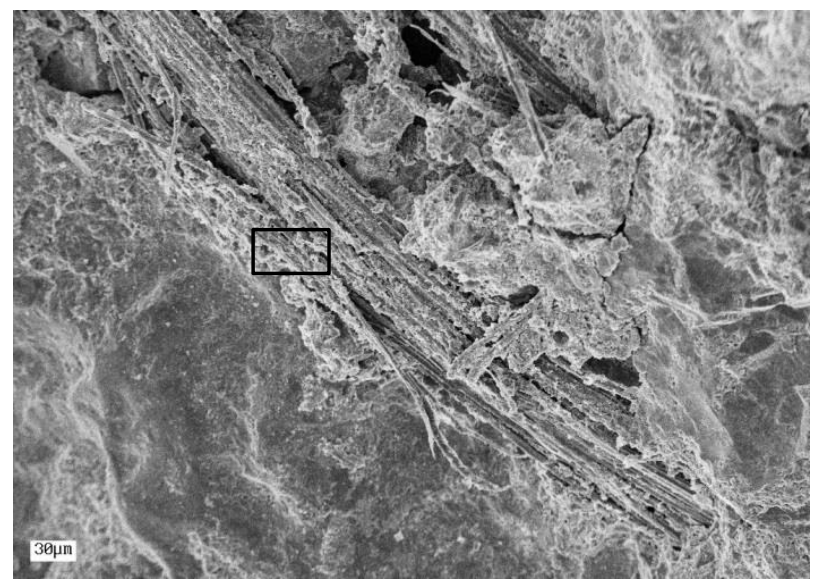

(a)

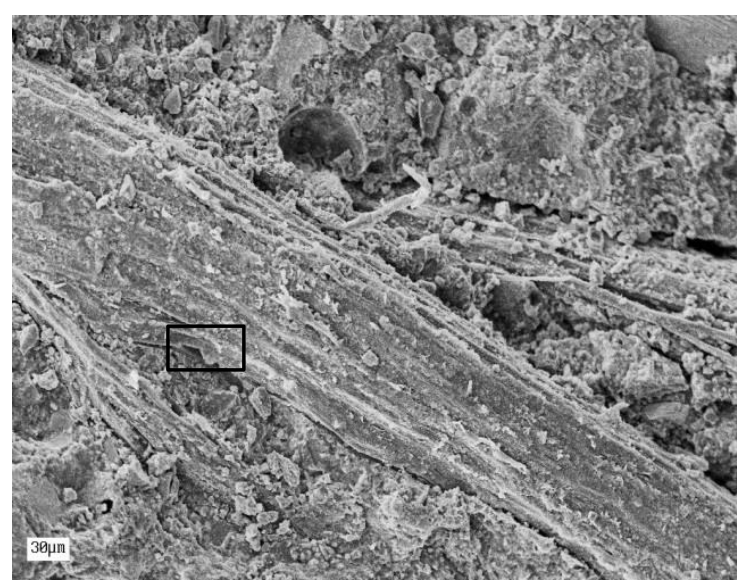

(b)

Figura 6.25 - Microimagens da matriz reforçada com a fibra de sisal: (a) matriz comum e (b) matriz modificada (Fonte: autor)

É possível perceber, segundo as imagens da Figura 6.25, maior degradação da fibra imersa na matriz com o cimento Portland ARI quando comparada à fibra imersa na matriz modificada. A presença de fibras vegetais em meios agressivos como é o caso de matrizes à base de cimento com alto teor de clínquer poder levar à deterioração das macrofibras e à perda de ductilidade das células individuais de celulose, como também foi observado por Savastano et al. (2009), Silva et al. (2009) e Toledo et al. (2003).

A Figura 6.26 mostra os espectros de EDS realizados na zona de transição fibra/matriz, cujas áreas foram destacadas nas imagens da Figura 6.25 por um quadrado. 


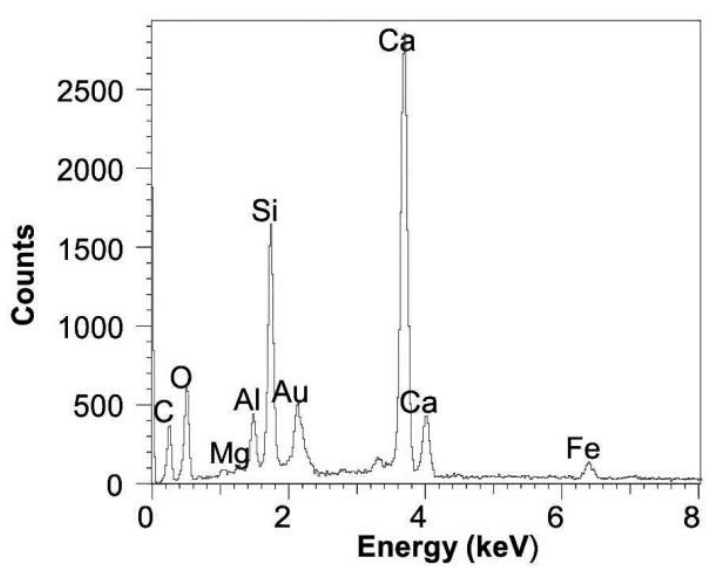

(a)

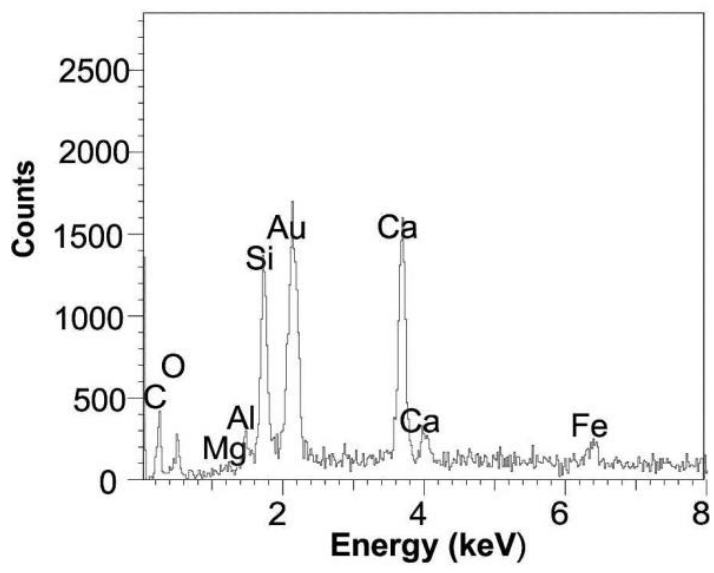

(b)

Figura 6.26 - Espectros obtidos por EDS na zona de transição fibra/matriz: (a) mistura comum e (b) mistura modificada (Fonte: autor)

Conforme afirma Richardson (2000), a relação $\mathrm{Ca} / \mathrm{Si}$ resultante da hidratação do cimento é em torno de 1,7 a 1,8. Com a adição de materiais pozolânicos como sílica e escória de alto, o $\mathrm{CH}$ resultante da hidratação é rapidamente consumido e a razão $\mathrm{Ca} / \mathrm{Si}$ cai para 0,7 a 0,8, possivelmente como resultado da maior formação de C-S-H. Esse mesmo comportamento pode-se notar nos espectros de EDS realizados na zona de transição fibra/matriz onde a razão $\mathrm{Ca} / \mathrm{Si}$ foi alta para os compostos com cimento Portland ARI e baixa para os compostos com a matriz modificada pelos materiais pozolânicos. Portanto, as partículas de sílica ativa incorporada na mistura reagiram com as partículas de $\mathrm{CH}$ que durante a hidratação do cimento se formaram preferencialmente na zona de interface. O produto desta reação é uma quantidade adicional de C-S-H. Devido à reação pozolânica e ao uso de um cimento menos alcalino foi criado um ambiente menos agressivo que favoreceu a durabilidade do sisal no concreto. 



\section{CONCLUSÕES E RECOMENDAÇÕES PARA TRABALHOS FUTUROS}

Com relação à caracterização dos resíduos, pode-se concluir que o pó de resíduo orgânico constitui um material que pode ser manipulado com segurança, por ser um resíduo com concentrações de metais pesados muito baixas. O resíduo está constituído por pequenas partículas de dimensão e formas variadas, que permite atuar como fíler, preenchendo os espaços na pasta de cimento. Quanto ao resíduo proveniente do setor mineral, o pó de pedra teve uma distribuição granulométrica que respeitou as especificações da NBR 7211: 2009 para a faixa granulométrica da zona 4 e pode ser considerado como uma areia grossa. Já o sisal apresentou baixa massa específica e elevada absorção de água. De fato constituem características comuns das fibras vegetais pela grande incidência de poros permeáveis.

Segundo os resultados obtidos no estudo piloto dos corpos de prova cilíndricos, as proporções dos pós residuais que causaram o melhor desempenho do concreto no estado fresco e endurecido variaram em função da relação cimento/agregado. No que concerne ao pó de pedra, a porcentagem ideal para a substituição da areia pelo pó foi de $60 \%$, em massa, para os traços 1:15 e 1:10 e de 40\%, em massa, para o traço 1:6. O fato de os exemplares com essas proporções terem obtido valores superiores nos ensaios pode dever-se ao correto empacotamento pela heterogeneidade granulométrica do resíduo. Esse efeito causou menor quantidade de vazios, menor porosidade, maior densidade, provocando um melhor comportamento físico e mecânico com relação aos concretos de referência. Os teores de pó residual orgânico também variaram em função do traço empregado. No concreto com baixo consumo de cimento, o pó não teve um correto enchimento na matriz cimentícia possivelmente pela maior quantidade de agregados que provocaram maior área superficial na mistura. A dosagem com médio consumo, o concreto com $5 \%$ de pó apresentou resistência à compressão superior ao concreto de referência, o que pode ser atribuído ao efeito físico de preenchimento dos vazios pelas partículas finas do resíduo. O resultado foi um concreto mais denso, com menor absorção e menor índice de vazios com relação ao concreto padrão. Em misturas ricas em cimento, as porcentagens de $5 \%$ e $10 \%$ de pó tiveram o melhor comportamento mecânico. Isso mostra o correto empacotamento provocado pelo pó de resíduo orgânico para essas proporções, preenchendo os vazios do material e refinando os poros da pasta de cimento.

Os blocos estruturais fabricados com os pós residuais e a fibra de sisal tiveram avaliadas suas propriedades geométricas e físicas como análise dimensional, absorção de água, massa 
específica e teor de umidade. Dessa forma, tendo os blocos outras propriedades avaliadas em trabalhos futuros como retração, durabilidade do pó residual orgânico e resistência ao fogo, é possível que essas unidades feitas com os materiais alternativos apresentem grande potencialidade para serem inseridas no mercado da construção.

Com base nos resultados de resistência à compressão dos blocos, prismas e pequenas paredes, o mesmo comportamento encontrado nos corpos de prova cilíndrico foi obtido para esses elementos com os resíduos. Dessa forma, foi comprovado estatisticamente que para o traço 1:15 o pó de resíduo não melhorou o desempenho dos blocos. Apesar disso, os blocos alcançaram a resistência característica pretendida (4 MPa). Por outro lado, teores de 5\% para o traço 1:10 e teores até $10 \%$ para o traço 1:6 causaram melhor desempenho mecânico com relação aos blocos de referência. Portanto, o pó de resíduo orgânico pode ser usado como material de enchimento do concreto substituindo parte do cimento devido à obtenção de blocos mais resistentes e densos e com menor absorção e índice de vazios, oferecendo assim, uma alternativa ao descarte do resíduo orgânico por meio da transformação em um pó reutilizável.

Analisando-se os resultados do módulo de deformação, nota-se que houve redução da rigidez dos prismas e das pequenas paredes com adição de $5 \%$ de pó de resíduo comparados com os elementos de referência para o traço 1:15. Já os exemplares construídos com blocos que apresentaram na mistura proporções de pó residual orgânico de 5 e $10 \%$ para os traços 1:10 e 1:6, respectivamente, tiveram maior módulo de deformação quando comparados aos elementos de controle. Esses resultados eram de certa forma esperados já que resistências maiores tendem a produzir um conjunto mais rígido.

Os blocos reforçados com fibras apresentaram diminuição da resistência à compressão em relação aos blocos sem fibras. Isso se deve a que o sisal aumentou o número de vazios e a absorção dos compósitos. Adicionalmente, foi formada mais uma zona de interface (fibra/pasta de cimento), além da interface agregado/pasta, aumentando o número de regiões porosas, frágeis e com microfissuras com relação ao concreto sem fibras.

Por outro lado, as paredes reforçadas com fibras tiveram melhor desempenho com relação aos prismas e blocos, apresentando resultados de resistência à compressão próximos aos exemplares de referência. Isso certamente está associado ao comportamento mecânico, que difere para cada tipo de elemento ensaiado. As pequenas paredes são os corpos de prova que melhor representam o modo de ruptura na alvenaria, no qual surgem maiores tensões de tração nas unidades devido às juntas verticais defasadas. Sob esse tipo de solicitação, as fibras 
atuam como reforço eficiente e podem efetivamente contribuir para melhorar a dissipação de energia por meio de pequenas fissuras dispersas por todo o material.

Tanto as pequenas paredes quanto os prismas com adição de sisal apresentaram ganho na capacidade de deformação, mostrado nas curvas tensão vs deformação. Isso foi produzido pelas fibras, que mantiveram as faces das fissuras unidas devido à aderência entre estas e a matriz cimentícia, não permitindo a perda de continuidade do material e tornando os compósitos vantajosos em termos de ductilidade.

De fato, o modo de ruptura ficou bem caracterizado em todos os corpos de prova ensaiados nesta pesquisa. No caso de unidades e elementos com adição de fibras obteve-se sempre uma ruptura progressiva. O sisal permite uma maior absorção de energia do compósito e confere ao material certa capacidade de absorver carregamentos após a fissuração, contribuindo para o aumento de sua tenacidade. Entretanto, nos blocos e nos elementos sem fibras correspondentes aos traços 1:15 e 1:10 ocorreu um rompimento com rápida propagação de fissuras, característico de um comportamento quase-frágil e ainda, as unidades e elementos de maior resistência pertencentes ao traço 1:6 apresentaram uma falha brusca devido ao comportamento frágil.

Com relação ao incremento da durabilidade das fibras no concreto, o sisal imerso na matriz modificada com sílica ativa e cimento a base de escórias de alto forno apresentou maior resistência à tração indireta com relação às fibras reforçando o concreto com cimento Portland ARI. As imagens obtidas no microscópico eletrônico de varredura mostraram o aspecto das fibras e foi claramente observado a degradação sofrida pelo sisal imerso na matriz cimentícia com alto teor de clínquer. Os materiais pozolânicos incorporados na matriz modificada provocaram um ambiente menos alcalino e agressivo para as fibras vegetais, diminuindo assim a quantidade de $\mathrm{CH}$ o que aumentou a durabilidade do sisal no concreto. Desse modo fica comprovado que uma forma para melhorar o desempenho das fibras consiste em modificar a composição da matriz a fim de reduzir o composto alcalino $\mathrm{CH}$ por meio da reação pozolânica. Isso permite aproveitar as vantagens das fibras no concreto em um longo período de tempo.

As curvas tração indireta $v s$ abertura da fissura dos blocos foram traçadas com o objetivo de calcular a energia de fratura. As unidades reforçadas com fibras tiveram maior ductilidade e absorção de energia com relação aos blocos de referência. Isso demostra que o concreto reforçado com as fibras vegetais apresentou bom desempenho na condição pósfissurado, melhor controle da fissuração e maior capacidade de carregamento após o aparecimento das primeiras trincas. 
A ferramenta estatística utilizada na pesquisa foi a técnica do Bootstrap que permitiu obter intervalos de confiança dos parâmetros estatístico da população para uma confiabilidade determinada. Dessa forma, foi obtida uma melhor interpretação dos resultados e foram tomadas as decisões sob o menor risco possível. Os intervalos de confiança são mais informativos e confiáveis do que um resultado simples extraído de uma amostra com observações limitadas no laboratório. Também a técnica do Bootstrap permitiu analisar a probabilidade de que as hipóteses nulas sejam aceitas, ou seja, obter de forma quantitativa quanto a média de uma população foi maior, igual ou menor que a outra população. Essa análise brindou uma interpretação mais exata do que um simples resultado do teste de hipótese, no qual apenas se aceita ou rejeita a hipótese nula.

Por meio dessas constatações expostas até aqui, afirma-se que a pesquisa pode ser considerada um avanço para uma construção sustentável. A utilização de resíduos, como pó residual orgânico e pó de pedra, e a utilização de fibra vegetal como o sisal na fabricação de blocos de concreto podem trazer benefícios sociais pelo fato da geração de mais emprego e renda para toda a sociedade como um todo; benefícios económicos pela redução de recursos naturais que são utilizados na fabricação dos blocos convencionais e benefícios ambientais devido à diminuição da quantidade de resíduos depositados em aterros sanitários e ao reaproveitamento desses materiais deixando de ser um problema de saúde pública e ambiental e passando a ser uma fonte de material alternativo a ser empregado com sucesso na construção civil.

\subsection{Recomendações para trabalhos futuros}

Ainda há muito para ser estudado sobre a utilização dos pós residuais e da fibra de sisal no concreto. Por conseguinte, faz-se necessário o desenvolvimento de novos trabalhos com intuito de atestar e avançar na tecnologia do concreto com resíduos e materiais não convencionais.

As principais sugestões para novas pesquisas são descritas abaixo:

- Avaliação do índice de atividade pozolânica do pó residual orgânico com a pasta de cimento;

- Estudo da retração por secagem dos blocos produzidos com os pós residuais e a fibra de sisal e comparação com a retração dos blocos de referência;

- Realização de testes de lixiviação e solubilização em blocos feitos com os pós residuais e a fibra de sisal; 
- Avaliação da durabilidade dos blocos com adição dos pós residuais por meio da análise da profundidade de carbonatação;

- Estudo do desempenho mecânico dos blocos reforçados com o sisal diante da ação do fogo;

- Avaliação da microestrutura do concreto do bloco com adição dos pós residuais;

- Análise econômica detalhada do processo de reciclagem e produção de blocos com os pós residuais considerando-se os custos do processo de reciclagem (custos de implantação, operação e manutenção) e do próprio custo de produção dos blocos com os resíduos;

- Estudo do comportamento de argamassas produzidas com o pó de resíduo orgânico;

- Verificação de possíveis expansões volumétricas na mistura que poderiam ser causadas pelo pó residual orgânico.

- Aplicações futuras da técnica estatística do Bootstrap poderiam contemplar uma avaliação do possível erro contido nos intervalos de confiança fornecidos por essa técnica. O erro nos intervalos de confiança depende do tamanho da amostra e do desvio padrão da população. 



\section{REFERÊNCIAS}

AL-AMOUDI, O. S. B.; MASLEHUDDIN, M.; ASI, I. M. Performance and correlation of the properties of fly ash cement concrete. Cement, Concrete and Aggregates, v. 18, n. 2, 1996. ISSN 0149-6123.

AL-RAWAS, A. A. et al. Use of incinerator ash as a replacement for cement and sand in cement mortars. Building and Environment, v. 40, n. 9, p. 1261-1266, Sep 2005. ISSN 0360-1323. Disponível em: < <Go to ISI>://WOS:000230499900011 >.

ALVES, A. T. J. et al. Reciclagem: educar para conscientizar. XVII Seminário Interinstitucional de Ensino, Pesquisa e Extensão, 2012, Universidade de Cruz Alta, Cruz Alta/RS, Brasil.

AMERICAN CONCRETE INSTITUTE. ACI 530: building code requirements for masonry structures and specifications for masonry structures. Detroit. 2011.

AMERICAN SOCIETY FOR TESTING AND MATERIALS. ASTM C1006-7: standard test method for splitting tensile strength of masonry units. 2010

.ASTM C270: standard specification for mortar for unit masonry. 1987

ASSOCIAÇÃO BRASILEIRA DA CONSTRUÇÃO INDUSTRIALIZADA (ABCI). Manual técnico de alvenaria. São Paulo, 1990.

ASSOCIAÇÃO BRASILEIRA DE NORMAS TÉCNICAS. NBR NM 23: cimento Portland e outros materiais em pó - determinação da massa específica. Rio de Janeiro, 2001.

NBR NM 45: agregados - determinação da massa unitária e do volume de vazios. Rio de Janeiro, 2006.

NBR NM 46: agregados - determinação do material fino que passa através da peneira 75 um, por lavagem. Rio de Janeiro, 2003.

NBR NM 52: agregado miúdo - determinação de massa específica e massa específica aparente. Rio de Janeiro, 2009.

Janeiro, 2003.

NBR NM 248: agregados: determinação da composição granulométrica. Rio de

NBR 5733: cimento Portland de alta resistência inicial. Rio de Janeiro, 1991.

NBR 5735: cimento Portland de alto-forno. Rio de Janeiro, 1991.

Janeiro, 2014.

NBR 6136: blocos vazados de concreto simples para alvenaria - requisitos. Rio de

NBR 7175: cal hidratada para argamassas - requisitos. Rio de Janeiro, 2003.

NBR 7211: agregados para concreto - especificação. Rio de Janeiro, 2009. 
- NBR 8522: concreto - determinação do módulo estático de elasticidade à compressão. Rio de Janeiro, 2008.

NBR 8798: execução e controle de obras em alvenaria estrutural de blocos vazados de concreto. Rio de Janeiro, 1985.

. NBR 9778: argamassas e concretos endurecidos: determinação da absorção de água por imersão - índice de vazios e massa específica. Rio de Janeiro, 2005.

. NBR 9935: agregados - terminologia. Rio de Janeiro, 2011.

. NBR 10004: Resíduos sólidos - Classificação. Rio de Janeiro, 2004.

. NBR 11578: cimento Portland composto - especificação. Rio de Janeiro, 1997.

. NBR 11579. cimento Portland - determinação do índice de finura por meio da peneira $75 \mu \mathrm{m}\left(\mathrm{n}^{\mathrm{o}} 200\right)$. Rio de Janeiro, 2012.

. NBR 12118: blocos vazados de concreto simples para alvenaria - métodos de ensaio. Rio de Janeiro, 2013.

NBR 12655: concreto de cimento Portland - preparo, controle, recebimento e aceitação - procedimento. Rio de Janeiro, 2015.

NBR 13276: argamassa para assentamento e revestimento de paredes e tetos preparo da mistura e determinação do índice de consistência. Rio de Janeiro, 2005.

. NBR 13281: argamassa para assentamento e revestimento de paredes e tetos requisitos. Rio de Janeiro, 2005.

NBR 15812-2: alvenaria estrutural - blocos cerâmicos, parte 2: Execução e controle de obras. Rio de Janeiro, 2010. Janeiro, 2011.

NBR 15961-1: alvenaria estrutural - blocos de concreto, parte 1: Projetos. Rio de

. NBR 15961-2: alvenaria estrutural - blocos de concreto, parte 2: Execução e controle de obras. Rio de Janeiro, 2011.

BRITISH STANDARD INSTITUTION. BS 5628-2: code of practice for the use of masonry: structural use of reinforced and prestressed masonry. England, 2000.

CCE/CBIC - Comissão de Economia e Estatística da Câmara Brasileira da Indústria da Construção, 2011.

ALMEIDA, E. D. Potencial de utilização do resíduo "carepa de aço" na fabricação de blocos de concreto. 2009. 97 (Dissertação de mestrado). Ambiente e Desenvolvimento, CENTRO UNIVERSITÁRIO UNIVATES 
ARUNTAS, H. Y. et al. Utilization of waste marble dust as an additive in cement production. Materials \& Design, v. 31, n. 8, p. 4039-4042, Sep 2010. ISSN 0261-3069. Disponível em: < $<$ Go to ISI $>$ ://WOS:000279118300062 >.

BARBOSA, M. P. et al. A influência da adição de finos basálticos nas características reológicas e mecânicas dos concretos auto-adensáveis (CAA). $46^{\circ}$ Congresso Brasileiro de Concreto. Anais. Florianópolis, 2004.

BERGSTRÖM, S. G.; GRAM, H.-E. Durability of alkali-sensitive fibres in concrete. International Journal of Cement Composites and Lightweight Concrete, v. 6, n. 2, p. 7580, $1984 . \quad$ Disponível em: http://www.sciencedirect.com/science/article/pii/0262507584900368 >.

BERHANE, Z. Performance of natural fiber-reinforced mortar roofing tiles. Materials and Structures, v. 27, n. 170, p. 347-352, Jul 1994. ISSN 0025-5432. Disponível em: < <Go to ISI $>: / / W O S: A 1994 N Z 42000006>$.

BOZZOLA, J. J.; Russell, L. D. Electron Microscopy. Jones and Bartlett Publishers, 1992.

BUTTLER, A. M. Uso de agregados reciclados de concreto em blocos de alvenaria estrutural. 2007. 98 p (Tese, Doutorado em Engenharia de Estruturas). Escola de Engenharia de São Carlos, Universidade de São Paulo, São Carlos

BUTTLER, A. M.; CORRÊA, M. R. S. Desenvolvimento de unidades de alvenaria estrutural produzidas com agregados reciclados de concreto. Cadernos de Engenharia de Estruturas, v. 8, n. 32, p. 9-12, 2006.

CAETANO, L. F. et al. Compósito de matriz cimentícia reforçada com fibras. In: II SEMINÁRIO DE PATOLOGIA DAS EDIFICAÇÕES, Porto Alegre. Anais: ... Porto Alegre, Brasil. 1 CD-ROM, 2004. p.4.

CAMPOS, R. E. Desempenho à compressão de compósitos reforçados por fibras de coco. 2008. 198 p (Trabalho de Conclusão de Curso). Universidade Federal de Sergipe, Sergipe.

CHANDRA, S. Waste materials used in concrete manufacturing. Noyes Publications, Westwood, New Jersey, USA: 1997. ISBN 0080946305.

CHEEMA, T. S.; KLINGNER, R. E. Tensile anchorage behavior of deformed reinforcement in grouted concrete masonry. Journal of the American Concrete Institute, v. 82, n. 3, p. 372-380, 1985. Disponível em: <<Go to ISI>://WOS:A1985AJT7400014 >. 
CHEN, H. X.; MA, X. W.; DAI, H. J. Reuse of water purification sludge as raw material in cement production. Cement \& Concrete Composites, v. 32, n. 6, p. 436-439, Jul 2010. ISSN 0958-9465. Disponível em: < <Go to ISI >:/WOS:000278158200005 >.

CHENG, H.; HU, Y. Municipal solid waste (MSW) as a renewable source of energy: Current and future practices in China. BIORESOURCE TECHNOLOGY, v. 101, n. 11, p. 38163824, 2010. Disponível em: http://www.sciencedirect.com/science/article/pii/S0960852410000970 >.

CINCOTTO, M. A. Utilização de subprodutos e resíduos na indústria da construção civil. Tecnologia das edificações. São Paulo: PINI, p. 71-74, 1988.

COLVILlE, J.; MILTENBERGER, M. A.; WOLDE-TINSAE, A. M. Hollow concrete masonry modulus of elasticity. The sixth North American Masonry Conference, Philadelphia, Pennsylvania, 1993.

CRUZ, M. P. N. Reaproveitamento de resíduos de resina de poliéster insaturado com fibra de vidro na fabricação de blocos de concreto para alvenaria. 2007. (Trabalho de Graduação). Engenharia de Materiais, Universidade Federal de Santa Catarina

DA MATA, R. C.; RAMALHO, M. A. Análise experimental e numérica do comportamento de junta da alvenaria. Cadernos de Engenharia de Estruturas, v. 11, n. 53, p. 45-49, 2009.

DAVISON, A. C. Bootstrap methods and their application. Cambridge University Press, 1997. ISBN 0521574714.

DE OLIVEIRA, L. M. F.; CORRÊA, M. R. S. ESTUDO TEÓRICO E EXPERIMENTAL DO COMPORTAMENTO DAS INTERFACES VERTICAIS DE PAREDES INTERCONECTADAS DE ALVENARIA ESTRUTURAL. Cadernos de Engenharia de Estruturas, v. 13, n. 59, p. 13-16, 2011. ISSN 1809-5860.

DHANASEKAR, M. Performance of brick masonry under Biaxial Loading. 1985. Dissertation submitted to the University of Newcastle in partial fulfillment of requirements for degree of doctor of philosophy, Australia

DICICCIO, T. J.; EFRON, B. Bootstrap confidence intervals. Statistical Science, v. 8, n. 3, p. 189-228, 1996. ISSN 0883-4237.

DRYSDALE, R. G.; KHATTAB, M. M. Shrinkage characteristics of concrete blocks. In: CANADIAN MASONRY SYMPOSIUM, 7., 1995, Hamilton, Ontario. Proceedings... Canada, 1995, p. 950-960., 1995. 
EIRES, R. New Eco-Friendly Gypsum Materials for Civil Construction. Materials Science Forum, v. 587 - 588, p. 908-912, 2008. Disponível em: < http://www.scientific.net/MSF.587-588.908 >.

ELYAMANY, H. E.; ABD ELMOATY, A. E. M.; MOHAMED, B. Effect of filler types on physical, mechanical and microstructure of self compacting concrete and Flow-able concrete. Alexandria Engineering Journal, v. 53, n. 2, p. 295-307, 2014. Disponível em: < http://www.sciencedirect.com/science/article/pii/S1110016814000313 >.

EN 1996-1-1. (2005). Eurocode 6 - Design of masonry structures - Part 1-1: General rules for reinforced and unreiforced masonry structures. European Standard.

FERRARIS, M. et al. Use of vitrified MSWI bottom ashes for concrete production. Waste Management, v. 29, n. 3, p. 1041-1047, Mar 2009. ISSN 0956-053X. Disponível em: < <Go to ISI>://WOS:000263444200007 >.

FERREIRA, C.; RIBEIRO, A.; OTTOSEN, L. Possible applications for municipal solid waste fly ash. Journal of Hazardous Materials, v. 96, n. 2-3, p. 201-216, Jan 2003. ISSN 03043894. Disponível em: < <Go to ISI>://WOS:000180320800008 >.

FERREIRA, S. R. et al. Influência de ciclos molhagem-secagem em fibras de sisal sobre a aderência com matrizes de cimento Portland. Matéria (Rio de Janeiro), v. 17, n. 2, p. 10241034, 2012. ISSN 1517-7076. Disponível em: < http://www.scielo.br/scielo.php?script=sci_arttext\&pid=S1517$\underline{70762012000200008 \& n r m=\text { iso }}>$.

FIORITI, C. F. Avaliação de compósitos de concreto com resíduos de borracha na produção de blocos para alvenaria. 2002. 134 p (Dissertação, Mestrado). Faculdade de Engenharia de Ilha Solteira, Universidade Estadual Paulista, São Paulo.

FIORITI, C. F.; AKASAKI, J. L. Fabricação de blocos estruturais de concreto com resíduos de borracha de pneus. Holos Environment, v. 4, n. 2, p. 145-156, 2007. ISSN 1519-8634.

FRASSON JUNIOR, A. Proposta de metodologia de dosagem e controle do processo produtivo de blocos de concreto para alvenaria estrutural. 2000. 146 p (Dissertação, Mestrado). Departamento de Engenharia Civil, Universidade Federal de Santa Catarina, Florianópolis.

FREITAS, A. A. Estudo Numérico e Experimental da Compressão de Peças de Alvenaria Estrutural. Relatório técnico final do projeto de auxílio à pesquisa apresentado à FAPESP, 2006. 
GARCEZ, L.; GARCEZ, C. Lixo, coleção Planeta Saudável. $1^{\text {ra }}$ edição. São paulo: Callis Editora Ltd, 2010. 32.

GORI, M. et al. Effect of natural ageing on volume stability of MSW and wood waste incineration residues. Waste Management, n. 0, 2012. Disponível em: < http://www.sciencedirect.com/science/article/pii/S0956053X12005508 >.

GUIMARAES, M. S. et al. Aggregate production: Fines generation during rock crushing. International Journal of Mineral Processing, v. 81, n. 4, p. 237-247, Jan 2007. ISSN 03017516. Disponível em: <<Go to ISI >://WOS:000244217000004 >.

HAMID, A. A.; DRYSDALE, R. G. Suggested failure criteria for grouted concrete masonry under axial compression. ACI Journal Proceedings, 1979, ACI.

HE, P. J. et al. Characteristics of air pollution control residues of MSW incineration plant in Shanghai. Journal of Hazardous Materials, v. 116, n. 3, p. 229-237, Dec 2004. ISSN 03043894. Disponível em: < <Go to ISI >:/WOS:000226264600006 >.

HEGEMEIR, G. et al. Prism tests for the compressive strength of concrete masonry. Proceedings of North American Masonry Conference. University of Colorado, 1978. p.181-1.

HENDRY, A. W.; Sinha, B. P.; Davies, S. Design of masonry structures. CRC Press, 2003. ISBN 0203362403.

HOLANDA, O. G. J. Blocos de concreto para alvenaria estrutural. In: $42^{\circ}$ CONGRESSO BRASILEIRO DO CONCRETO- IBRACON, Fortaleza. Anais: 42 $^{\circ}$ IBRACON, Fortaleza, Brasil. 1 CD-ROM, 2000.

IZQUIERDO, I. S. Uso de fibra natural de sisal em blocos de concreto para alvenaria estrutural. 2011. 128 p (Dissertação, Mestrado). Departamento de Estruturas, Escola de Engenharia de São Carlos, Universidade de São Paulo, São Carlos - SP.

IZQUIERDO, O. S.; CORRÊA, M. R. S. ESTUDO DA INTERFACE BLOCO/GRAUTE EM PEÇAS DE ALVENARIA ESTRUTURAL. Cadernos de Engenharia de Estruturas, v. 15, n. 65, p. 9-12, 2014. ISSN 1809-5860.

JAHNEL, M. C.; MELLONI, R.; CARDOSO, E. J. B. N. MATURIDADE DE COMPOSTO DE LIXO URBANO. Scientia Agricola, v. 56, p. 301-304, 1999. ISSN 0103-9016. Disponível em: < http://www.scielo.br/scielo.php?script=sci_arttext\&pid=S0103$\underline{90161999000200007 \& \text { nrm }=\text { iso }}>$. 
JERONIMO, C. E. M.; SANTIAGO JR, A. F. Desafios da administração ambiental publica: estudo de caso do município de Espírito Santo/RN. Revista de Administração de Roraima, v. 2, n. 1, p. 136-146, 2012.

JERONIMO, F. D. P. Stabilization of organic waste process and product thus obtained. Brasil. BR2010PI05284 201012162013.

JOHN, V. M. et al. Durability of slag mortar reinforced with coconut fibre. Cement \& Concrete Composites, v. 27, n. 5, p. 565-574, May 2005. ISSN 0958-9465. Disponível em: < $<$ Go to ISI $>$ ://WOS:000228543200007 >.

JOSEPH, K.; THOMAS, S.; PAVITHRAN, C. Effect of chemical treatment on the tensile properties of short sisal fibre-reinforced polyethylene composites. Polymer, v. 37, n. 23, p. 5139-5149, Nov 1996. ISSN 0032-3861. Disponível em: < <Go to ISI>://WOS:A1996VT19600005 >.

JOUDI-BAHRI, I. et al. Use of limestone sands and fillers in concrete without superplasticizer. Cement and Concrete Composites, v. 34, n. 6, p. 771-780, 2012. Disponível em: < http://www.sciencedirect.com/science/article/pii/S0958946512000376 >.

JUNG, C. H. et al. Metal distribution in incineration residues of municipal solid waste (MSW) in Japan. Waste Management, v. 24, n. 4, p. 381-391, 2004. Disponível em: < http://www.sciencedirect.com/science/article/pii/S0956053X03001375 >.

JUNIOR, P. F. Desenvolvimento de produto sustentável: bloco de alvenaria com adição de poliestireno expandido. 2013. 72 (Dissertação de mestrado). Engenharia de Produção, Universidade Federal de Itajubá

JUSTE, A. E. Estudo da resistência e da deformabilidade da alvenaria de blocos de concreto submetida a esforços de compressão. 126p. 2001. Dissertação (Mestrado)-Escola de Engenharia de São Carlos, Universidade de São Paulo, São Carlos

KARAKUS, A. Investigating on possible use of Diyarbakir basalt waste in Stone Mastic Asphalt. Construction and Building Materials, v. 25, n. 8, p. 3502-3507, Aug 2011. ISSN 0950-0618. Disponível em: < <Go to ISI>://WOS:000291411200042 >.

KINGSLEY, G. R. Masonry. In: (Ed.). New York: Academic Press, 2003. p.133-143.

KNUTSON, H. The elastic stress-strain relationship for masonry'. Mas. Inter, v. 7, n. 1, p. 31-33, 1993. 
KNUTSON, H. H.; NIELSEN, J. On the modulus os elasticity for masonry. Masonry International Journal, v. 9, n. 2, p. 59-61, 1995.

LAGERBLAD, B.; VOGT, C. Fillers and ultrafine fillers to save cement and improve concrete properties. Proceedings of 8th International Symposium on Utilization of High Strength and High Performance Concrete, 2008. p.168-176.

LEE, M. Y. et al. Artificial stone slab production using waste glass, stone fragments and vacuum vibratory compaction. Cement \& Concrete Composites, v. 30, n. 7, p. 583-587, Aug 2008. ISSN 0958-9465. Disponível em: <<Go to ISI>://WOS:000257974700004 >.

LI, Y.; MAI, Y.-W.; YE, L. Sisal fibre and its composites: a review of recent developments. Composites Science and Technology, v. 60, n. 11, p. 2037-2055, 2000. Disponível em: < http://www.sciencedirect.com/science/article/pii/S0266353800001019 >.

LIMA, P. R. L. et al. Caracterização mecânica de laminados cimentíceos esbeltos reforçados com fibras de sisal. Revista Brasileira de Engenharia Agrícola e Ambiental, v. 11, n. 6, p. 644-651, 2007.

LIN, K. L. et al. Effects of $\mathrm{Al} 2 \mathrm{O} 3$ on the hydration activity of municipal solid waste incinerator fly ash slag. Cement and Concrete Research, v. 34, n. 4, p. 587-592, 2004. Disponível em: < http://www.sciencedirect.com/science/article/pii/S0008884603003478 >.

LINO, F. A. M.; Ismail, K. A. R. Analysis of the potential of municipal solid waste in Brazil. Composites Science and Technology, v. 4, n. 0, p. 105-113, 2012. Disponível em: < http://www.sciencedirect.com/science/article/pii/S2211464512001091 >.

LINS, D. N.; JÚNIOR, R. P. D. S. Fabricação de bloco de concreto utilizando resíduos da indústria de artefatos de cimento. 2014. 38 (Título de Bacharel). Engenharia Civil, Universidade Católica de Brasília

LOGULLO, B. Influência do graute e da taxa de armadura no comportamento da alvenaria de blocos de concreto. 2006. Dissertação (Mestrado)-Faculdade de Engenharia de Ilha Solteira-FEIS, Universidade Estadual Paulista, 192p., Ilha Solteira.

MARQUES, M. L.; CAMPOS, K. D. A. Estudo da adição do pó de pedra em argamassas de revestimento e assentamento. Revista Pindorama, v. 3, n. 3, p. 150-164, 2012.

MATA, R. C. D. Influência do padrão de argamassamento na resistência à compressão de prismas e mini-paredes de alvenaria estrutural de blocos de concreto. 2006. $180 \mathrm{p}$ (Dissertação). Engenharia Civil - PPGEC, Universidade Federal de Santa Catarina 
MATHEW, A. et al. Analysis of masonry panel under biaxial bending using ANNs and CBR. Journal of computing in civil engineering, v. 13, n. 3, p. 170-177, 1999. ISSN 0887-3801.

MEDEIROS, J. S.; SABBATINI, F. H. Alvenaria estrutural não armada de blocos de concreto: produção de componentes e parâmetros de projeto. Boletim Técnico da Escola Politécnica da USP. São Paulo: Escola Politécnica da USP, 1993.

MEHTA, P. K.; MONTEIRO, P. J. M. Concreto: microestrutura, propriedades e materiais. Tradução da 3. ed. em inglês. São Paulo: Ibracon., 2008. 674 p. ISBN 8598576123.

MENOSSI, R. Utilização do pó de pedra basáltica em substituição à areia natural do concreto. 2004. 97 p (Dissertação, Mestrado). Programa de Pós-Graduação em Engenharia Civil, Universidade Estadual Paulista, Ilha Solteira,.

MILANESE, A. C.; CIOFFI, M. O. H.; VOORWALD, H. J. C. Thermal and mechanical behaviour of sisal/phenolic composites. Composites Part B-Engineering, v. 43, n. 7, p. 2843-2850, Oct 2012. ISSN 1359-8368. Disponível em: < <Go to ISI >://WOS:000307143600018>.

MIRANDA, L. F. R. et al. Use of Recycled Sand Produced at Construction Sites in Bedding Mortars. Journal of Materials in Civil Engineering, v. 25, n. 2, p. 236-242, Feb 2013. ISSN 0899-1561. Disponível em: < <Go to ISI>://CCC:000315467500010 >.Disponível em: < http://www.asce.org >.

MOHAMAD, G. Comportamento mecânico na ruptura de prismas de blocos de concreto. 1998. Dissertação (Mestrado em Engenharia Civil)-UFSC, Florianópolis. 1998$178 \mathrm{p}$

MOHAMAD, G.; LOURENCO, P. B.; ROMAN, H. R. Mechanics of hollow concrete block masonry prisms under compression: Review and prospects. Cement \& Concrete Composites, v. 29, n. 3, p. 181-192, Mar 2007. ISSN 0958-9465. Disponível em: < <Go to ISI $>: / / W O S: 000244702400004>$.

MOHAMAD, G.; LOURENÇO, P. B.; ROMAN, H. R. Ensaios de compressão em prismas de blocos de concreto à compressão: deformabilidade e modo de rotura. 2004. ISSN 1415-3025.

MOHAMAD, G. et al. Mechanical behaviour of bedding mortar for structural masonry preview and failure mode. Materia-Rio De Janeiro, v. 14, n. 2, p. 824-844, Aug 2009. ISSN 1517-7076. Disponível em: < <Go to ISI>://WOS:000269838800006 >. 
MOHAN, T. P.; KANNY, K. Chemical treatment of sisal fiber using alkali and clay method. Composites Part a-Applied Science and Manufacturing, v. 43, n. 11, p. 1989-1998, Nov 2012. ISSN 1359-835X. Disponível em: < <Go to ISI>://WOS:000309646900020>.

MULLER, U.; RUBNER, K. The microstructure of concrete made with municipal waste incinerator bottom ash as an aggregate component. Cement and Concrete Research, v. 36, n. 8, p. 1434-1443, Aug 2006. ISSN 0008-8846. Disponível em: < <Go to ISI $>: / /$ WOS:000240299100004 >.

NUNES JUNIOR, J. J. Efeito do pó de pedra em argamassa para alvenaria estrutural. 2013.

OKSMAN, K. et al. Morphology and mechanical properties of unidirectional sisal- epoxy composites. Journal of Applied Polymer Science, v. 84, n. 13, p. 2358-2365, 2002. Disponível em: < http://dx.doi.org/10.1002/app.10475 >.

PARSEKIAN, G.; HAMID, A.; DRYSDALE, R. Comportamento e dimensionamento de alvenaria estrutural. São Carlos: EdUFSCar, v. 1, p. 625, 2012.

PASQUALI, I. Influencia do tipo de argamassamento na resistência à compressão de pequenas paredes de alvenaria estrutural cerâmica. 2007. 138 p (Dissertação, Mestrado). Universidade Federal de Santa Maria, Rio Grande do Sul.

PERSSON, K. Micromechanical modelling of wood and fibre properties. Lund University, Department of Mechanics and Materials, 2000. ISBN 9178740940.

PICANÇO, M. S. Compósitos cimentícios reforçados com fibras de curauá. 2005. (Dissertação, Mestrado). Pontifícia Universidade Católica do Rio de Janeiro, Rio de Janeiro.

PRUDÊNCIO, L. R.; OLIVEIRA, A. L. D.; FRASSON, A. Metodologia de dosagem para blocos de concreto empregados em alvenaria estrutural. Revista Prisma, v. Parte 2, 2000. ISSN 1809-4708.

RAMALHO, M. A.; CORRÊA, M. R. S. Projeto de edifícios de alvenaria estrutural. São Paulo: Editora Pini, 1a edição: 2003. 188p.

RAMIRES, E. C. et al. Biobased composites from glyoxal-phenolic resins and sisal fibers. Bioresource Technology, v. 101, n. 6, p. 1998-2006, Mar 2010. ISSN 0960-8524. Disponível em: < <Go to ISI >://WOS:000274271400064 >.

REBMANN, M. Durabilidade de concretos estruturais com baixo consumo de cimento Portland e alta resistência. 2011. 211 p (Dissertação, Mestrado). Departamento de Estruturas, Escola de Engenharia de São Carlos, Universidade de São Paulo, São Carlos - SP. 
REIS, J. M. L. Sisal fiber polymer mortar composites: Introductory fracture mechanics approach. Non Destructive Techniques for Assessment of Concrete, v. 37, n. 0, p. 177-180, 2012. em:

http://www.sciencedirect.com/science/article/pii/S0950061812005582 >.

RICHARDSON, I. G. The nature of the hydration products in hardened cement pastes. Cement and Concrete Composites, v. 22, n. 2, p. 97-113, 2000. Disponível em: < http://www.sciencedirect.com/science/article/pii/S0958946599000360 >.

RODRIGUEZ, N. H. et al. Evaluation of spray-dried sludge from drinking water treatment plants as a prime material for clinker manufacture. Cement \& Concrete Composites, v. 33, n. 2, p. 267-275, Feb 2011. ISSN 0958-9465. Disponível em: < <Go to ISI $>$ ://WOS:000287342600014 >.

ROMAGNA, R. H. Resistência a compressão de prismas de blocos de concreto grauteados e não grauteados. 2000. 195 p (Dissertação, Mestrado). Universidade Federal de Santa Catarina, Florianópolis

ROWELL, R. M.; SCHULTZ, T. P.; NARAYAN, R. Emerging technologies for materials and chemicals from biomass. ACS Publications, 1992. ISBN 0841221715.

RÉMOND, S.; PIMIENTA, P.; BENTZ, D. P. Effects of the incorporation of Municipal Solid Waste Incineration fly ash in cement pastes and mortars: I. Experimental study. Cement and Concrete Research, v. 32, n. 2, p. 303-311, 2002. Disponível em: < http://www.sciencedirect.com/science/article/pii/S0008884601006743 >.

SABOYA, F.; XAVIER, G. C.; ALEXANDRE, J. The use of the powder natural stone byproduct to enhance the properties of brick ceramic. Construction and Building Materials, v. 21, n. 10, p. 1950-1960, Oct 2007. ISSN 0950-0618. Disponível em: < <Go to ISI $>$ ://WOS:000248778100006 >.

SAIKIA, N.; KATO, S.; KOJIMA, T. Production of cement clinkers from municipal solid waste incineration (MSWI) fly ash. Waste Management, v. 27, n. 9, p. 1178-1189, 2007. Disponível em: < http://www.sciencedirect.com/science/article/pii/S0956053X06001905 >.

SANTIAGO, B. H.; SELVAM, P. V. P. Tratamento superficial da fibra de coco: estudo de caso baseado numa alternativa econômica para fabricação de materiais compósitos. Revista analítica, v. 26, p. 42-45, 2007.

SAVASTANO, $\mathrm{H}$. et al. Fracture and fatigue of natural fiber-reinforced cementitious composites. Cement \& Concrete Composites, v. 31, n. 4, p. 232-243, Apr 2009. ISSN 09589465. Disponível em: <<Go to ISI>:/WOS:000265720800003>. 
SAVASTANO JR, H.; WARDEN, P. G.; COUTTS, R. S. P. Mechanically pulped sisal as reinforcement in cementitious matrices. Cement and Concrete Composites, v. 25, n. 3, p. 311-319, 2003. Disponível em: http://www.sciencedirect.com/science/article/pii/S0958946502000550 $>$.

SHRIVE, N.; EL-RAHMAN, M. Understanding the cause of cracking in concrete: a diagnostic aid. Concrete International, v. 7, n. 5, p. 39-44, 1985.

SHRIVE, N. G. The failure mechanism of face-shell bedded ungrouted and unreinforced masonry. International Journal for Masonry Construction, v. 9, n. 1, p. 115-128, 1982.

SIDDIQUE, R. Utilization of municipal solid waste (MSW) ash in cement and mortar. Resources Conservation and Recycling, v. 54, n. 12, p. 1037-1047, Oct 2010. ISSN 09213449. Disponível em: < <Go to ISI>://WOS:000281752400002 >.

SILVA, F.; TOLEDO FILHO, R. Sisal Fibre Reinforcement of Durable Thin-walled Structures-A New Perspective. CBM-CI International Workshop, 2008.

SILVA, F. D.; MOBASHER, B.; TOLEDO, R. D. Cracking mechanisms in durable sisal fiber reinforced cement composites. Cement \& Concrete Composites, v. 31, n. 10, p. 721-730, Nov 2009. ISSN 0958-9465. Disponível em: <<Go to ISI>://WOS:000271850300005 >.

SILVA, F. D. et al. Physical and mechanical properties of durable sisal fiber-cement composites. Construction and Building Materials, v. 24, n. 5, p. 777-785, May 2010. ISSN 0950-0618. Disponível em: < <Go to ISI>://WOS:000276181500017 >.

SILVA, F. D. A.; CHAWLA, N.; ROMILDO FILHO, D. T. Mechanical behavior of natural sisal fibers. Journal of Biobased Materials and Bioenergy, v. 4, n. 2, p. 106-113, 2010. ISSN 1556-6560.

SILVA, F. D. A. et al. Physical and mechanical properties of durable sisal fiber-cement composites. v. 24, n. 5, p. 777-785, 2010. Disponível em: < http://www.sciencedirect.com/science/article/pii/S0950061809003675 >.

SILVA, F. D. A.; MOBASHER, B.; SORANAKOM, C. Effect of fiber shape and morphology on interfacial bond and cracking behaviors of sisal fiber cement based composites. Cement and Concrete Composites, v. 33, n. 8, p. 814-823, 2011. ISSN 09589465.

SILVA, N. G.; BUEST, G. T.; Campiteli, V. C. A influência do filler de areia britada de rocha calcária nas propriedades da argamassa de revestimento. In: II SEMINÁRIO DO USO DA FRAÇÃO FINA DA BRITAGEM, São Paulo. Anais: ... São Paulo, Brasil. 1 CD-ROM, 2005. p.12. 
SILVA, O. R.; BELTRÃO, N. E. d. M. Agronegócio do sisal no Brasil. Brasília: EmbrapaSPI/Embrapa-CNPA, p. 205, 1999.

SILVEIRA, J. P.; ROCHA, J. C.; CHERIAF, M. Desenvolvimento de blocos de concreto com uso das cinzas de termelétricas. In: ENCONTRO NACIONAL DE TECNOLOGIA DO AMBIENTE CONSTRUÍDO, São Paulo. Anais:... São Paulo: ANTAC, 2004. CD-ROM., 2004. p.10.

SINGHAL, A.; TEWARI, V. K.; PRAKASH, S. Utilization of treated spent liquor sludge with fly ash in cement and concrete. Building and Environment, v. 43, n. 6, p. 991-998, Jun 2008. ISSN 0360-1323. Disponível em: < <Go to ISI>://WOS:000254216900002 >.

SOLÓRZANO, M. Características e desempenho de juntas de argamassa na alvenaria estrutural de blocos de concreto. 1994, 60p. 1994. Dissertação (Mestrado em Engenharia Civil)-Escola Politécnica da Universidade de São Paulo, São Paulo, 1994.[Links]

SOTO, I. I.; RAMALHO, M. A. Blocks of concrete reinforced with natural sisal fibres for use in masonry. In: 8th RILEM INTERNATIONAL SYMPOSIUM ON FIBRE REINFORCED CONCRETE: CHALLENGES AND OPPORTUNITIES-BEFIB, Guimarães. Proceedings: Eight RILEM International Symposium-BEFIB, Guimarães, Portugal. 1 CD-ROM, 2012.

SOTO, I. I.; RAMALHO, M. A. Use of natural sisal fibre in concrete blocks for strutural masonry. In: 15th INTERNATIONAL BRICK AND BLOCK MASONRY CONFERENCEIBMAC, Florianópolis. Proceedings: 15th IBMAC, Florianópolis, Brasil. 1 CD-ROM, 2012.

SOUTO, J. M. F.; VANDERLEI, R. D.; NUNES, I. H. S. Avaliação do desempenho da cinza do bagaço de cana-de- açúcar na produção de concretos., In: 51 $1^{\circ}$ CONGRESSO BRASILEIRO DO CONCRETO- IBRACON, Curitiba. Anais: 51 ${ }^{\circ}$ IBRACON, Curitiba, Brasil. 1 CD-ROM, 2010.

TANGO, C. E. S. Fundamentos de dosagem de concreto para blocos estruturais-IPT-São Paulo. In: 5th INTERNACIONAL SEMINAR ON STRUCTURAL MANSORY FOR DEVELOPING COUNTRIES,Florianópolis. Proceedings: 5th Iternacional Seminar on Structural Mansory for Developing Countries, Florianópolis, Brazil., 1994.

THOMASON, J. L. et al. Fibre cross-section determination and variability in sisal and flax and its effects on fibre performance characterisation. Composites Science and Technology, v. 71, n. 7, p. 1008-1015, May 2011. ISSN 0266-3538. Disponível em: < <Go to ISI >://WOS:000291297200009 >.

TOLEDO, R. D. et al. Development of vegetable fibre-mortar composites of improved durability. Cement \& Concrete Composites, v. 25, n. 2, p. 185-196, Feb 2003. ISSN 09589465. Disponível em: < <Go to ISI $>/ /$ WOS:000181186500004 >. 
TOLEDO, R. D. et al. Durability of alkali-sensitive sisal and coconut fibres in cement mortar composites. Cement \& Concrete Composites, v. 22, n. 2, p. 127-143, Apr 2000. ISSN 09589465. Disponível em: < <Go to ISI >:/WOS:000086767400005 >.

VAN GERVEN, T. et al. Management of incinerator residues in Flanders (Belgium) and in neighbouring countries. A comparison. Waste Management, v. 25, n. 1, p. 75-87, 2005. ISSN 0956-053X. Disponível em: < <Go to ISI>://WOS:000227102000010 >.

VIANA, E; MATTAR, D. C. UTILIZAÇÃO DE RESÍDUOS POLIMÉRICOS DA INDÚSTRIA DE RECICLAGEM DE PLÁSTICO EM BLOCOS DE CONCRETO. Revista Eletrônica em Gestão, Educação e Tecnologia Ambiental, v. 8, n. 8, p. 1722-1733, 2013. ISSN 2236-1170.

VOGT, C. Ultrafine particles in concrete. 2010. Doctoral Thesis, School of Architecture and the Built Environment, Royal Institute of Technology, Stockholm, Sweden

WU, K. et al. Preparation of alinite cement from municipal solid waste incineration fly ash. Cement \& Concrete Composites, v. 34, n. 3, p. 322-327, Mar 2012. ISSN 0958-9465. Disponível em: <<Go to ISI>://WOS:000300811600004 >.

ZANTA, V. M.; FERREIRA, C. F. A. Gerenciamento integrado de resíduos sólidos urbanos. Resíduos Sólidos Urbanos: Aterro Sustentável para Municípios de Pequeno Porte, v. 1, p. 1-16, 2003.

ZHAI, X. M.; STEWART, M. G. Structural reliability analysis of reinforced grouted concrete block masonry walls in compression. Engineering Structures, v. 32, n. 1, p. 106-114, Jan 2010. ISSN 0141-0296. Disponível em: <<Go to ISI>://WOS:000272956800010 >.

ZHANG, H.; HE, P.-J.; SHAO, L.-M. Fate of heavy metals during municipal solid waste incineration in Shanghai. Journal of Hazardous Materials, v. 156, n. 1-3, p. 365-373, 2008. Disponível em: http://www.sciencedirect.com/science/article/pii/S0304389407017803 >.

ZHOU, X. et al. Fracture and impact properties of short discrete jute fibre-reinforced cementitious composites. Materials \& Design, v. 49, n. 0, p. 35-47, 2013. Disponível em: < http://www.sciencedirect.com/science/article/pii/S0261306913000435 >. 


\section{APÊNDICE A - TÉCNICA ESTATÍSTICA DO BOOTSTRAP}

\section{A1 Introdução}

A técnica de Bootstrap é um método de reamostragem proposto por Bradley Efron em 1979, como abordagem ao cálculo de intervalos de confiança de parâmetros quando o número de amostras é reduzido (Davison, 1997).

A reamostragem consiste em sortear com reposição os dados pertencentes a uma amostra retirada anteriormente, de modo a formar uma nova amostra. Dessa maneira, diferentes estatísticas podem ser calculadas em cada conjunto de dados, tais como a média, o desvio padrão, entre outras. Assim, utilizando as diferentes estatísticas calculadas em cada reamostragem, o Bootstrap pode ser utilizado para avaliar a distribuição de uma estatística e para estimar o intervalo de confiança.

Segundo Davison (1997), repetir um procedimento de análise original com muitas réplicas de dados pode ser denominado método intensivo computadorizado. Para realizar uma estimação por meio da utilização de Bootstrap é necessária a realização de um número muito grande de reamostragens e o cálculo de diversas estatísticas para cada uma destas reamostragens. Isso exige o auxílio de programas computacionais para realizar os cálculos de forma mais rápida e eficaz. Nesta pesquisa o programa utilizado foi o Matlab.

Em geral, o Bootstrap é uma metodologia para avaliar a precisão de uma estatística, que é questão fundamental em muitas áreas de pesquisa. Nesse sentido, em comparação com outros métodos (por exemplo, simulação de Monte Carlo), as principais vantagens do Bootstrap são que não necessita da experiência ser repetida muitas vezes já que não precisa de um grande número de observações. No entanto, os dados originais tem que ser uma boa representação da população e não devem incluir muitos desvios.

\section{A2 Procedimento de cálculo do Bootstrap}

Considerando o problema de encontrar o intervalo de confiança de uma estatística $\theta$, o Bootstrap pressupõe que os próprios dados originais $\mathrm{X}=\left(\mathrm{X}_{1}, \mathrm{X}_{2}, \ldots \mathrm{X}_{\mathrm{n}}\right)$ constitui a distribuição desconhecida da variável aleatória $X$. Então, pela reamostragem de $\mathrm{X}$ muitas vezes e o cálculo de $\hat{\theta}$ para cada um dessas reamostras, é possível obter uma distribuição de Bootstrap para $\widehat{\theta}$, o qual se aproxima a distribuição de $\theta$, e é possível estimar o intervalo de confiança derivado de $\theta$. Este procedimento está descrito na Tabela A1. 
Existem diferentes técnicas para o cálculo do intervalo de confiança a partir de estimativas do Bootstrap, como o método $\mathrm{BCa}$, o método $\mathrm{ABC}$, método Bootstrap-t e o método Percentil. O trabalho por Diciccio e Efron (1996) descreve a teoria que existe detrás desses métodos e faz uma comparação entre as vantagens e limitações de cada um deles. Nesse sentido, este trabalho só aplica o método Percentil para estimar o intervalo de confiança, como mostra a Tabela A1.

Tabela A1 - O procedimento do Bootstrap para calcular o intervalo de confiança com o método Percentil (Fonte: autor)

Passo 0: Realização do experimento. Supor que os dados originais são dados por.

$$
X=\left\{X_{1}, X_{2}, X_{3} \ldots, X_{n}\right\}_{1 x n}
$$

Passo 1: Reamostragem. Desenhar uma amostra aleatória de $n$ valores, com a reposição de X. Reamostragem do Boostrap é:

$$
X^{*}=\{?, ?, ? \ldots, ?\}_{1 x n}
$$

Nesta etapa é possível que alguns dos dados originais apareçam mais de uma vez e os outros não

Passo 2. Cálculo da estimativa de Bootstrap. Calcular a estatística $\hat{\theta}^{*}$, que pode ser a média, desvio padrão, entre outros.

Passo 3. Repetição. Repetir os passos 1 e 2 com um elevado número de vezes para se obter um total B das estimativas de Bootstrap: $\hat{\theta}_{1}^{*}, \hat{\theta}_{2}^{*} \ldots . \hat{\theta}_{B}^{*}$.

Passo 4. Intervalo de confiança pelo método percentil. O intervalo do Bootstrap de $100(1-\alpha) \%$ de confiança é $\left(\hat{\theta}_{q_{1}}^{*}, \hat{\theta}_{q_{2}}^{*}\right)$, onde $q_{1}=B \alpha / 2$ e $q_{2}=B-q_{1}+1$ e $\alpha$ é o nível de significância.

\section{A3 Número de reamostras adequado}

Para que a aplicação da técnica resulte em valores confiáveis devem ser feitas, a partir da amostra mestre, centenas ou até milhares de reamostras do mesmo tamanho n. O número de reamostragem pode ser estimado verificando a variação do desvio padrão do estatístico para diferentes tamanhos da reamostragem no Bootstrap. No momento em que esse valor encontre-se estabilizado, o tamanho da reamostra Bootstrap estará adequado. 
O processo é o seguinte: a partir da amostra mestre é feito B reamostragens, seguido é calculado a estatística (média ou desvio padrão) de cada uma das reamostras e se obtém o desvio padrão dessas B reamostras. Esse processo deve ser realizado várias vezes (neste caso foi repetido 20 vezes). Portanto, tem-se 20 desvios padrões em que é calculado o desvio padrão desses valores. Todo o processo é realizado para diferentes tamanhos de reamostragem, e se obtém para cada valor de B um ponto na gráfica. A Figura A1 mostra um diagrama do processo para um melhor entendimento.

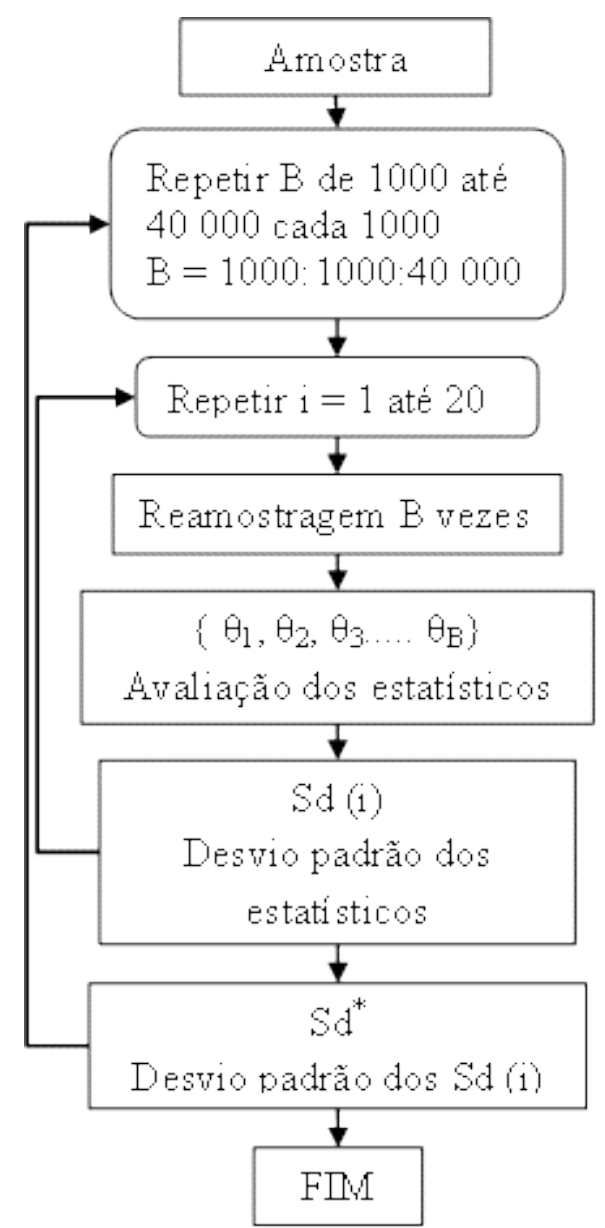

Figura A1 - Diagrama do processo para obter a quantidade de reamostras adequadas (Fonte: autor)

As Figura A2 e a Figura A3 mostram o desvio padrão do estatístico (média e desvio padrão, respectivamente) em 20 simulações do mesmo tamanho B a medida que aumenta o número de reamostragem. 


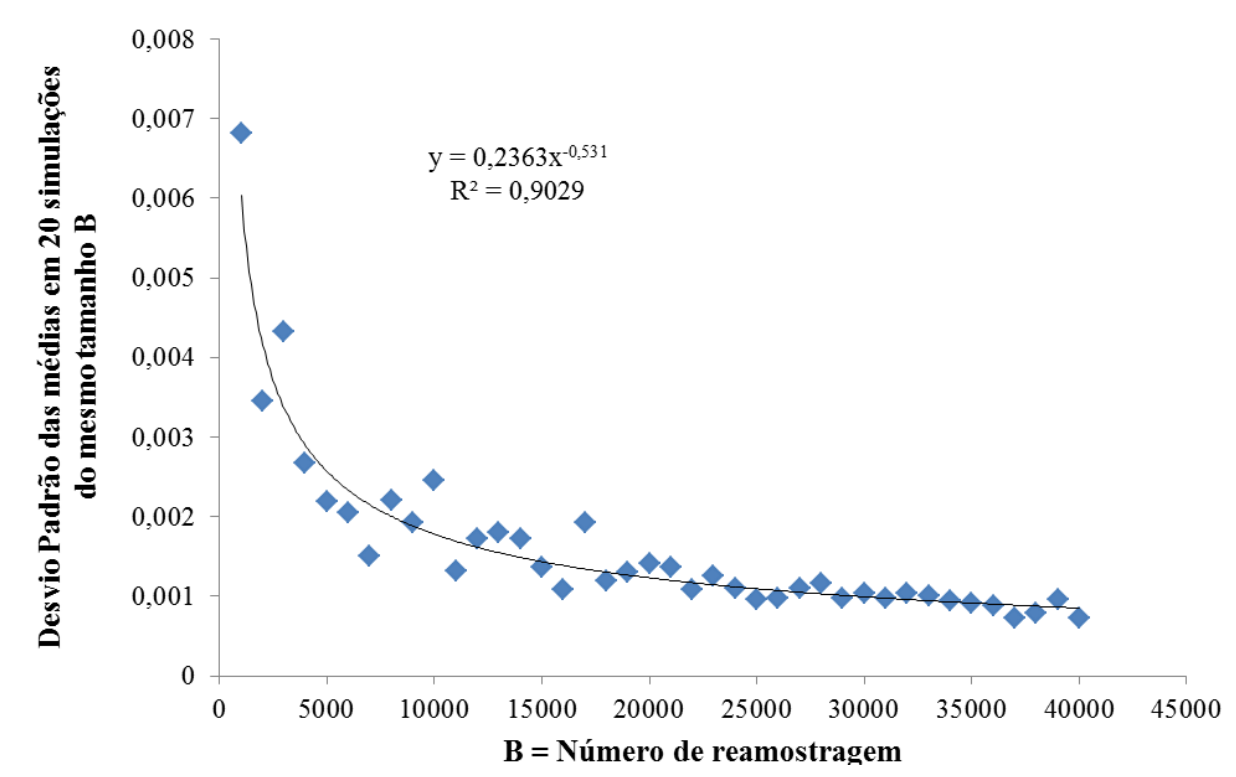

Figura A2 - Desvio padrão das médias em 20 simulações do mesmo tamanho B (Fonte: autor)

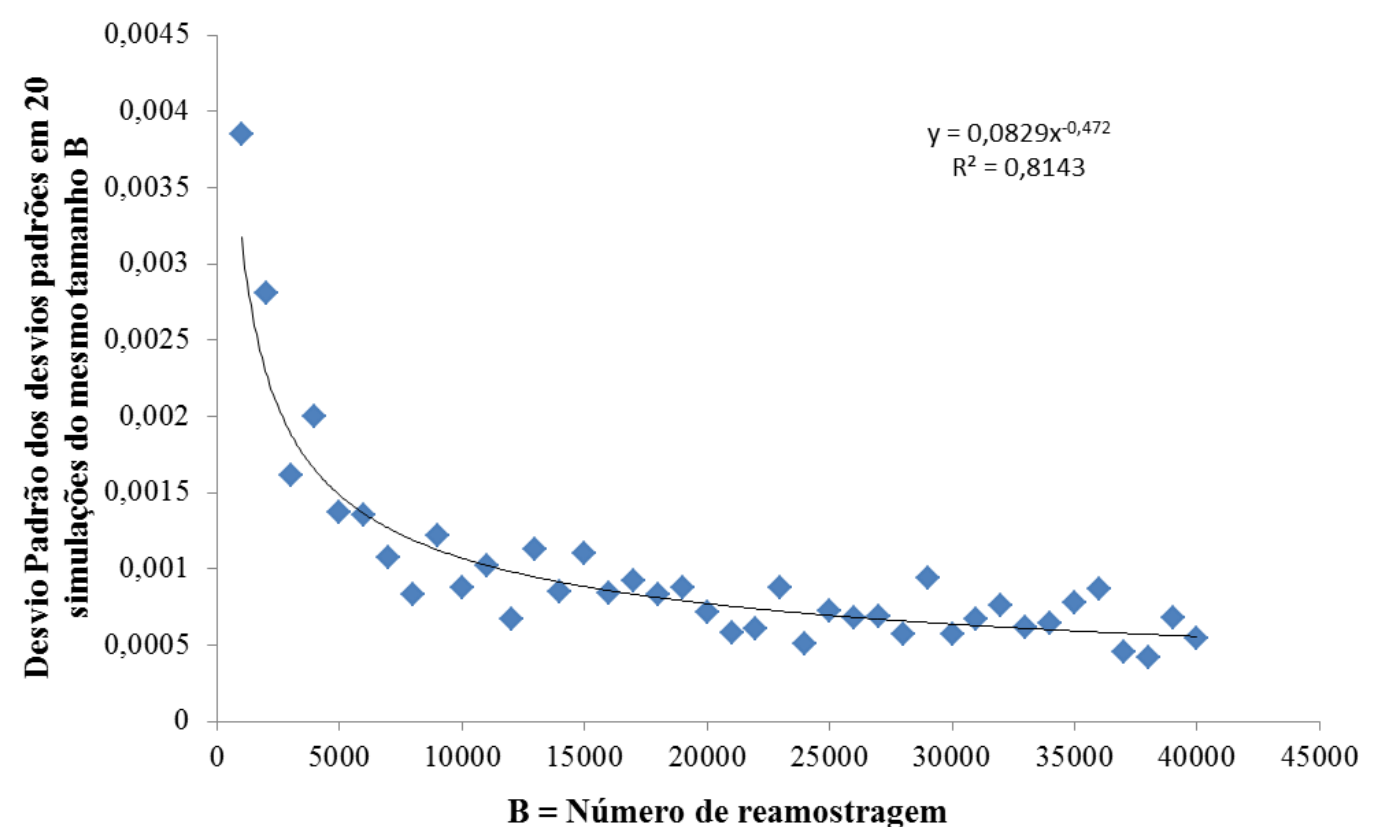

Figura A3 - Desvio padrão dos desvios padrões em 20 simulações do mesmo tamanho B

Podem-se notar em ambos os gráficas que o desvio padrão começa a permanecer constante a partir de 20000 reamostragem. Portanto, esse será o número de reamostragem escolhido para usar a técnica do Bootstrap.

A4 Procedimento da técnica do Bootstrap para obter intervalos de confiança da resistência característica

Uma vez geradas as reamostras, deve-se calcular as estatísticas de média e desvio padrão para cada uma delas. Dessa forma, é suposto que a população responde a uma distribuição de probabilidade normal com média e desvio padrão calculados em cada 
reamostra. Assim, é avaliado o valor correspondente ao quantil de $5 \%\left(\mathrm{f}_{\mathrm{ck}}\right)$ da curva de distribuição de probabilidade normal para cada reamostragem. Com os valores de resistência característica, correspondente a cada reamostra, é gerado um histograma da distribuição de probabilidade e calculado os intervalos de confiança do $f_{c k}$ por meio do método percentil mostrado na Tabela A1. A Figura A4 representa um esquema do procedimento descrito.

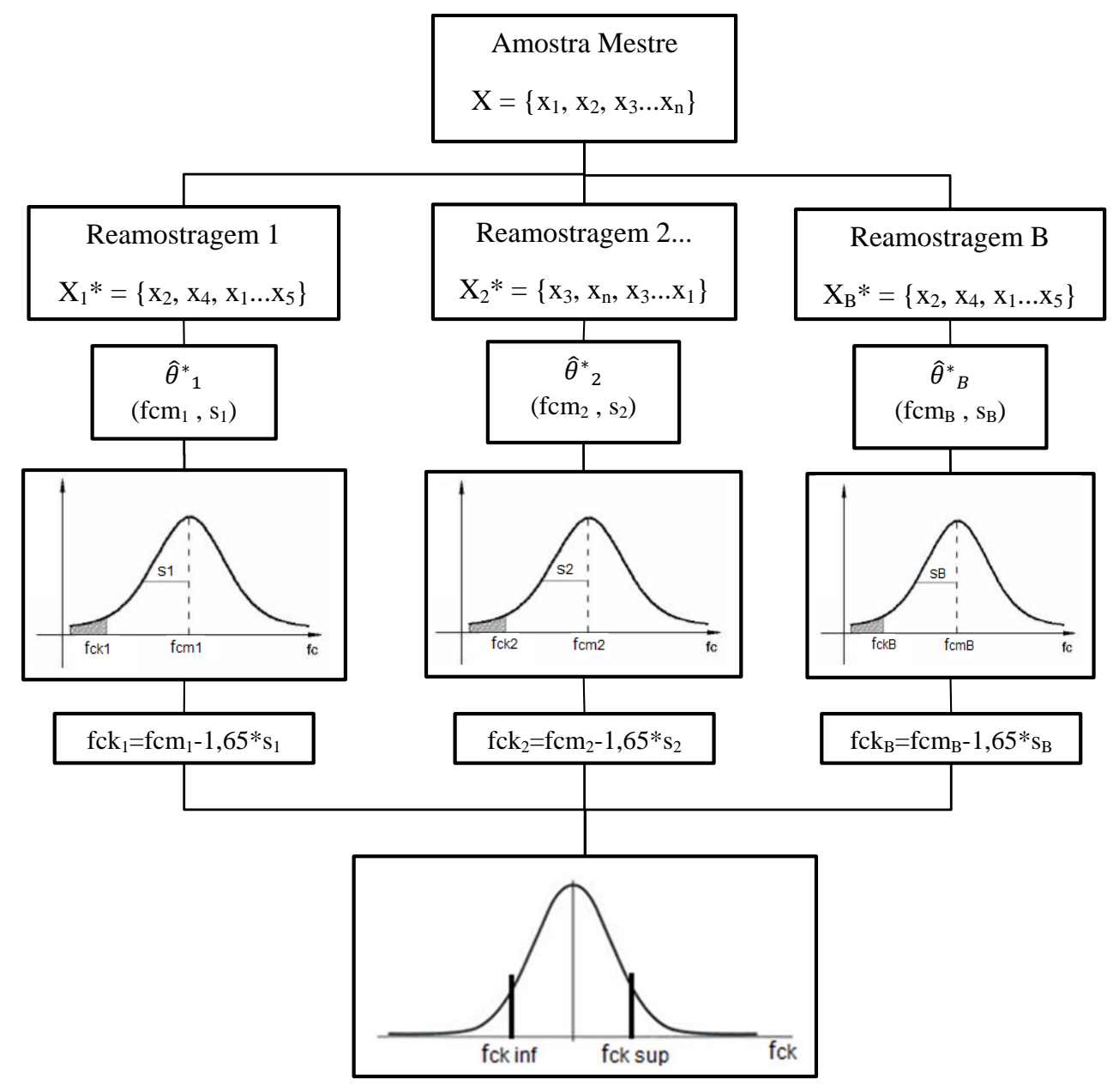

Figura A4 - Esquema do procedimento para o cálculo dos intervalos de confiança da resistência característica 



\section{APÊNDICE B - ANÁLISE DA DIFERENÇA ENTRE DUAS MÉDIAS COM O MÉTODO BOOTSTRAP}

\section{B1 Introdução}

Tradicionalmente, o teste de hipótese é usado para estudar a diferença nos parâmetros de duas populações. Basicamente, esse método consiste em testar a igualdade de dois parâmetros, de acordo a um predeterminado umbral de probabilidade. Assim, um nível de significância é definido para criar uma região crítica. Esta região crítica define o conjunto de todos os resultados que fazem com que, se ocorrerem, levará a decidir que há diferença entre os parâmetros (resultado negativo). Em contraste, um resultado fora da região crítica levará a decidir que não há diferença (resultado positivo). O resultado positivo indica que a hipótese nula é aceita e o resultado negativo que a hipótese nula é rejeitada em favor da hipótese alternativa. A hipótese nula refere-se à afirmação de ser testada, neste caso a igualdade de dois parâmetros.

No entanto, pelo meio de um teste simples de hipóteses entre os parâmetros das duas populações só resulta numa aceitação ou rejeição da hipótese nula, uma vez que um único parâmetro em cada população é usado para representar a característica de população. $\mathrm{O}$ método de Bootstrap pode estimar uma gama de valores possíveis de um parâmetro da população desconhecida, em vez de apenas um valor. Portanto, calculando teste de hipótese de cada valor do intervalo, é possível avaliar a probabilidade tanto de aceitação ou rejeição das hipóteses nulas. Esta probabilidade é mais informativa do que um simples resultado do teste de hipótese, onde apenas rejeita ou não rejeita a hipótese nula.

\section{B2 Procedimento de cálculo}

O teste de hipóteses considera a diferença das médias de $\mathrm{u}_{1}$ e $\mathrm{u}_{2}$ de duas distribuições normais, onde as variâncias $\sigma_{1}$ e $\sigma_{2}$ são desconhecidas e não necessariamente iguais $\left(\sigma_{1} \neq \sigma_{2}\right)$. Diferentes hipóteses nulas foram analisadas, como $\mathrm{H}_{01}: \mathrm{u}_{1}<\mathrm{u}_{2}, \mathrm{H}_{02}: \mathrm{u}_{1}=\mathrm{u}_{2}$ e $\mathrm{H}_{03}: \mathrm{u}_{1}>\mathrm{u}_{2}$. O teste estatístico $t$ é usado para testar estas hipóteses. A solução utilizando o procedimento de teste de hipóteses de quatro passos é mostrada na Tabela B1. 
Tabela B1 - Teste de hipótese para a diferença entre duas médias (Fonte: autor)

Passo 0. Avaliação dos parâmetros de interesse $\hat{u}_{1}, \hat{u}_{2}, \hat{\sigma}_{1}, \hat{\sigma}_{2}, \mathrm{n}_{1}$ e $\mathrm{n}_{2}$ dos dados originais, onde $n_{1}$ e $n_{2}$ são o tamanho da amostra das populações 1 e 2 , respectivamente.

Passo 1. Hipóteses nulas: $H_{01}: u_{1}<u_{2}, H_{02}: u_{1}=u_{2}$ e $H_{03}: u_{1}>u_{2}$

Passo 2. Definição do nível de significância.

Passo 3. O teste estatístico $t$

$$
t_{0}=\frac{\hat{u}_{1}-\hat{u}_{2}}{\sqrt{\frac{\hat{\sigma}_{1}^{2}}{n_{1}}-\frac{\hat{\sigma}_{2}^{2}}{n_{2}}}}
$$

com graus de liberdade dada por

$$
v=\frac{\left(\frac{\hat{\sigma}_{1}^{2}}{n_{1}}+\frac{\hat{\sigma}_{2}^{2}}{n_{2}}\right)^{2}}{\frac{\left(\hat{\sigma}_{1}^{2} / n_{1}\right)^{2}}{n_{1}-1}+\frac{\left(\hat{\sigma}_{2}^{2} / n_{2}\right)^{2}}{n_{2}-1}}
$$

Passo 4. Aceitar $\mathrm{H}_{01}$ se $t_{0}<-t_{\alpha, v}$

Aceitar $\mathrm{H}_{02}$ se $t_{0}>-t_{\alpha / 2, v}$ ou se $t_{0}<t_{\alpha / 2, v}$

Aceitar $\mathrm{H}_{03}$ se $t_{0}>t_{\alpha, v}$

Agora, pela reamostragem das populações $X_{1}$ e $X_{2}$ muitas vezes calculadas se obtém $\hat{u}_{1}, \hat{u}_{2}, \hat{\sigma}_{1}$ e $\hat{\sigma}_{2}$, e aplicando o teste de hipótese para cada um destas reamostras, é possível avaliar a probabilidade da hipótese nula, como é mostrado na Tabela B2. 
Tabela B2 - Probabilidade da hipótese nula com o método Bootstrap (Fonte: autor)

Passo 0: Os dados originais são dadas por.

$$
\begin{aligned}
& X_{1}=\left\{X_{11}, X_{12}, X_{13} \ldots, X_{1 n}\right\}_{1 x n_{1}} \\
& X_{2}=\left\{X_{21}, X_{22}, X_{23} \ldots, X_{2 n}\right\}_{1 x n_{2}}
\end{aligned}
$$

Passo 1: Reamostragem. Desenhar uma amostra aleatória de $\mathrm{X}_{1}$ e $\mathrm{X}_{2}$, as reamostras do Bootstrap são:

$$
\begin{aligned}
& X_{1}^{*}=\{?, ?, ? \ldots, ?\}_{1 x n_{1}} \\
& X_{2}^{*}=\{?, ?, ? \ldots, ?\}_{1 x n_{2}}
\end{aligned}
$$

Passo 2. Cálculo. Cálcular as estatísticas de cada reamostragem $\hat{u}_{1}, \hat{u}_{2}, \hat{\sigma}_{1}$ e $\hat{\sigma}_{2}$.

Passo 3. Decisão. Decidir se rejeitar a hipótese nula ou não rejeitá-la, de acordo com a Tabela B1.

Se a hipótese nula $\mathrm{H}_{01}$ é verdadeira então $\mathrm{Z}_{1}=\mathrm{Z}_{1}+1$

Se a hipótese nula $\mathrm{H}_{02}$ é verdadeira então $\mathrm{Z}_{2}=\mathrm{Z}_{2}+1$

Se a hipótese nula $\mathrm{H}_{03}$ é verdadeira então $\mathrm{Z}_{3}=\mathrm{Z}_{3}+1$

Onde $\mathrm{Z}_{1}, \mathrm{Z}_{2}$ e $\mathrm{Z}_{3}$ correspondem ao número de vezes que a hipótese nula $\mathrm{H}_{01}, \mathrm{H}_{02}$ e $\mathrm{H}_{03}$ são verdadeiras, respetivamente, e o valor inicial é igual a zero.

Passo 3. Repetição. Repetir os passos 1, 2 e 3 de um grande número de vezes para obter um total das estimativas de Bootstrap B.

Passo 4. Calcular a probabilidade das hipóteses nulas $\mathrm{H}_{01}, \mathrm{H}_{02}$ e $\mathrm{H}_{03}$, como.

$$
P H_{01}(\%)=100 * \frac{Z_{1}}{B}, P H_{02}(\%)=100 * \frac{Z_{2}}{B}, P H_{03}(\%)=100 * \frac{Z_{3}}{B}
$$





\section{APÊNDICE C - RESULTADOS DAS PROPRIEDADES GEOMÉTRICAS DOS BLOCOS}

Tabela C 1 - Largura, comprimento e altura real de cada tipo de bloco (Fonte: autor)

\begin{tabular}{|c|c|c|c|c|c|c|c|c|c|}
\hline \multirow{2}{*}{ Tipo de Bloco } & \multicolumn{3}{|c|}{ Largura $(\mathbf{m m})$} & \multicolumn{3}{|c|}{ Comprimento (mm) } & \multicolumn{3}{|c|}{ Altura (mm) } \\
\hline & Média & $S_{d}$ & C.V (\%) & Média & $S_{d}$ & C.V (\%) & Média & $S_{d}$ & C.V (\%) \\
\hline BE1:15-Ref & 139,94 & 0,64 & 0,45 & 388,67 & 1,24 & 0,32 & 189,50 & 1,54 & 81 \\
\hline BE1:15-5\%P.L & 140,51 & 1,35 & 0,96 & 389,17 & 1,15 & 0,30 & 190,11 & 1,28 & 0,67 \\
\hline BE1:10-Ref & 139,70 & 0,35 & 0,25 & 388,50 & 1,65 & 0,43 & 191,78 & 1,17 & 0,61 \\
\hline BE1:10-5\%P.L & 140,06 & 0,69 & 0,49 & 387,83 & 0,62 & 0,16 & 190,28 & 1,02 & 0,53 \\
\hline BE1:10-F1 & 140,05 & 0,52 & 0,37 & 388,33 & 0,77 & 0,20 & 189,78 & 1,70 & 0,90 \\
\hline BE1:1 & 139,94 & 0,56 & 0,40 & 388 & 0,92 & 0,24 & 189,28 & 1,27 & 0,67 \\
\hline BE1:6-Ref & 140,39 & 0,58 & 0,41 & 387,89 & 0,83 & 0,21 & 192,00 & 0,92 & 0,48 \\
\hline BE1:6-10\%P.L & 140,65 & 0,40 & 0,29 & 388,06 & 0,94 & 0,24 & 190,28 & 0,83 & 0,43 \\
\hline
\end{tabular}

Tolerâncias: $\pm 2,0 \mathrm{~mm}$ para largura, e $\pm 3,0 \mathrm{~mm}$ para altura e comprimento, expressas como a média das determinações executadas.

Tabela C 2 - Largura, comprimento e altura real de cada tipo de meio-bloco (Fonte: autor)

\begin{tabular}{|c|c|c|c|c|c|c|c|c|c|}
\hline \multirow{2}{*}{$\begin{array}{c}\text { Tipo de Meio- } \\
\text { Bloco }\end{array}$} & \multicolumn{3}{|c|}{ Largura (mm) } & \multicolumn{3}{|c|}{ Comprimento (mm) } & \multicolumn{3}{|c|}{ Altura (mm) } \\
\hline & Média & $S_{d}$ & C.V & Média & $\mathbf{S}_{\mathrm{d}}$ & C.V & Tédia & $S_{d}$ & C.V $(\%)$ \\
\hline E1:15-Ref & 140,23 & 0,56 & 0,4 & 190 & & 0,2 & 89,50 & 0,98 & 52 \\
\hline & & & & & & & & & \\
\hline 1. & 14 & 5 & & 8 & 0,87 & & 62 & 0,8 & 46 \\
\hline $1: 1$ & 140 & 0,63 & & 189 &, 96 & 0 & 23 & 0,99 & 2 \\
\hline & 139 & 0 , & & & & & 07 & 1,0 & \\
\hline & 1 & 5 & & & 7 & & 56 & 0,76 & 40 \\
\hline & 140,01 & 0,64 & & 19 & 0,72 & 0,3 & 190,65 & 1,14 & 0,60 \\
\hline E1:6-10\%P.L & 139,21 & 0,49 & 0,35 & 190,8 & 0,55 & 0,29 & 189,75 & 0,79 & 0,42 \\
\hline
\end{tabular}

Tolerâncias: $\pm 2,0 \mathrm{~mm}$ para largura, e $\pm 3,0 \mathrm{~mm}$ para altura e comprimento, expressas como a média das determinações executadas.

Tabela C 3 - Espessuras reais das paredes longitudinais e transversais dos blocos (Fonte: autor)

\begin{tabular}{|c|c|c|c|c|c|c|c|}
\hline \multirow[b]{3}{*}{ Tipo de Bloco } & \multicolumn{6}{|c|}{ Espessuras reais das paredes (mm) } & \\
\hline & \multicolumn{3}{|c|}{ Paredes longitudinais } & \multicolumn{4}{|c|}{ Paredes Transversais } \\
\hline & Média & $\mathbf{S}_{\mathrm{d}}$ & C.V (\%) & Média & $\mathbf{S}_{\mathbf{d}}$ & C.V (\%) & $\begin{array}{c}\text { Transversal } \\
\text { Equivalente } \\
(\mathbf{m m} / \mathbf{m})\end{array}$ \\
\hline BE1:15-Ref & 30,37 & 0,78 & 2,58 & 30,37 & 1,26 & 4,13 & 233,62 \\
\hline BE1:15-5\%P.L & 31,19 & 1,31 & 4,20 & 30,19 & 0,89 & 2,96 & 232,23 \\
\hline BE1:10-Ref & 30,62 & 0,69 & 2,26 & 29,98 & 0,80 & 2,65 & 230,62 \\
\hline BE1:10-5\%P.L & 31,19 & 1,31 & 4,20 & 30,19 & 0,89 & 2,96 & 232,23 \\
\hline BE1:10-F1 & 30,74 & 0,68 & 2,23 & 29,04 & 0,83 & 2,84 & 223,38 \\
\hline BE1:10-F2 & 30,79 & 0,65 & 2,12 & 29,82 & 0,35 & 1,18 & 229,38 \\
\hline BE1:6-Ref & 31,31 & 0,81 & 2,58 & 29,89 & 1,11 & 3,74 & 229,92 \\
\hline BE1:6-10\%P.L & 31,34 & 0,56 & 1,79 & 29,20 & 0,92 & 3,15 & 224,62 \\
\hline
\end{tabular}


Tabela C 4 - Menor dimensão dos furos dos blocos (Fonte: autor)

\begin{tabular}{lccc}
\hline \multirow{2}{*}{ Tipo de Bloco } & \multicolumn{3}{c}{ Menor dimensão dos furos (mm) } \\
\cline { 2 - 4 } & Média & $\mathbf{S}_{\mathbf{d}}$ & $\mathbf{C . V}(\boldsymbol{\%})$ \\
\hline BE1:15-Ref & 78,66 & 0,73 & 0,93 \\
BE1:15-5\%P.L & 76,46 & 0,97 & 1,26 \\
BE1:10-Ref & 77,81 & 0,37 & 0,48 \\
BE1:10-5\%P.L & 78,20 & 0,90 & 1,16 \\
BE1:10-F1 & 78,76 & 0,83 & 1,05 \\
BE1:10-F2 & 78,77 & 1,12 & 1,42 \\
BE1:6-Ref & 77,61 & 1,12 & 1,44 \\
BE1:6-10\%P.L & 78,26 & 0,88 & 1,13 \\
\hline A menor dimensão do furo não deve ser inferior a 70 mm \\
\hline \multicolumn{4}{c}{}
\end{tabular}

